UNIVERSIDADE DE SÃO PAULO

ESCOLA DE EDUCAÇÃO FÍSICA E ESPORTE

"AMARELÃO" NO ESPORTE: DAS ALTERAÇÕES DA COR DA PELE AO COPING DO ESTRESSE POR CRENÇAS RELIGIOSAS E O LÓCUS DE CONTROLE DE ATLETAS DE HANDEBOL, GINÁSTICA ARTÍSTICA E VOLEIBOL

Paulo Félix Marcelino Conceição

SÃO PAULO

2008 


\section{"AMARELÃO" NO ESPORTE: DAS ALTERAÇÕES DA COR DA PELE AO COPING DO ESTRESSE POR CRENÇAS RELIGIOSAS E O LÓCUS DE CONTROLE DE ATLETAS DE HANDEBOL, GINÁSTICA ARTÍSTICA E VOLEIBOL}

\section{PAULO FELIX MARCELINO CONCEIÇÃO}

Tese apresentada à Escola de Educação Física e Esporte da Universidade de São Paulo, como requisito parcial para obtenção do grau de Doutor em Educação Física e Esporte, na área de Biodinâmica do Movimento Humano. 
Conceição, Paulo Felix Marcelino

“Amarelão” no esporte: das alterações da cor da pele ao coping do estresse por crenças religiosas e o lócus de controle de atletas de handebol, ginástica artística e voleibol / Paulo Felix Marcelino Conceição. - São Paulo: [s.n.], 2008.

xviii, 176p.

Tese (Doutorado) - Escola de Educação Física e Esporte da Universidade de São Paulo.

Orientador: Prof. Dr. Antonio Carlos Simões.

1. Psicologia do Esporte. 2. Estresse. Título. 
Ao Prof. Dr. Antonio Carlos Simões, por ter conduzido com seriedade e competência a difícil aventura do saber.

Aos professores do curso de Pós-graduação, que me conduziram na busca de novos saberes nos encontros em sala de aula.

Aos Atletas, que colaboraram para a realização deste estudo e pela autenticidade de suas posturas.

Ao Sr. Antonio Francisco da T \& M Instruments Representações Ltda., que possibilitou e acreditou na realização desta pesquisa.

À Professora Ivone Borelli, pelo cuidado e amizade que brotaram ao longo dos anos de pesquisa

A todos que colaboraram direta ou indiretamente na realização desta pesquisa.

A meus pais, Ana e Álvaro e minha avó Marina, por terem-me inspirado confiança para persistir diante das incertezas.

A Sônia, companheira e suporte, em todos os momentos da minha vida acadêmica.

A meus filhos Apolo, Gabriel e Angélica e a recém chegada neta Sophia, que possam utilizar estes estudos em suas vidas. 


\section{SUMÁRIO}

LISTA DE TABELAS ..................................................................... ix

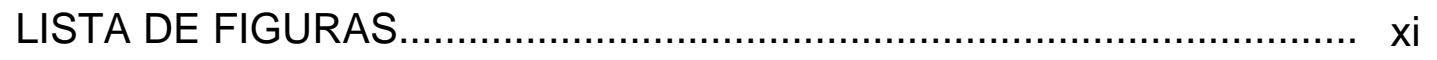

LISTA DE ANEXOS......................................................................

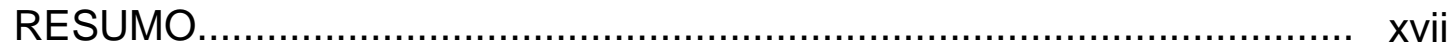

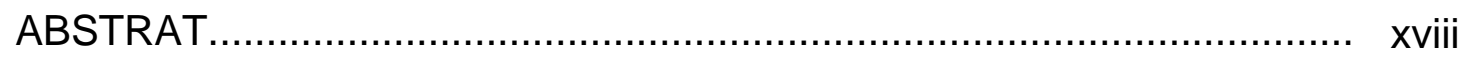

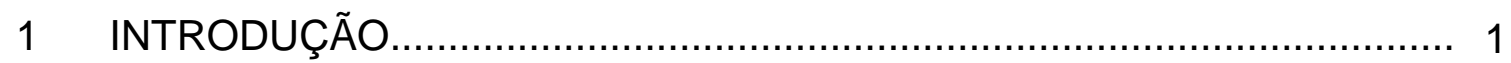

2 OBJETIVO GERAL................................................................... 5

2.1 Objetivos específicos............................................................... 5

3 JUSTIFICATIVA

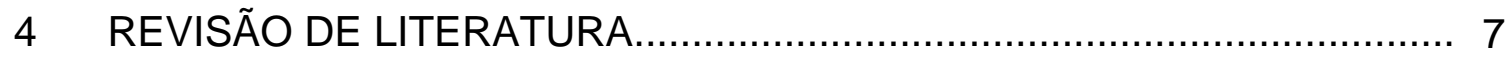

4.1 A interseção do cromatismo epitelial aos aspectos morfológicos da pele em conexão com o sistema nervoso....................................................... 8

4.2 A cromaticidade do tecido epitelial em conexão do estresse com o mimetismo em estudos com animais...................................................... 12

4.3 Conceitos básicos do estresse na física.............................................. 14

4.4 Conceitos básicos do estresse biológico e coping................................... 15

4.5 A pele como espaço de manifestações psicossomáticas........................... 22

4.6 Caracterização das crenças religiosas pelo Inventário Pratt de crenças religiosas no esporte.................................................................... 24

4.7 Caracterização das expectativas do controle do esporte pela Escala de lócus de controle do Esporte. 
4.8 Reflexões sobre dimensões do custo-benefício da mensuração da cor da pele e o impacto das expectativas no esporte de rendimento.

4.9 A percepção da cor da pele como sinal da natureza física da luz: dos conceitos de Isaac Newton a Albert Einstein

4.10 Alterações cromáticas do tecido epitelial e "amarelão" como medida objetiva por meio da espectrofotometria

4.11 Será que?.

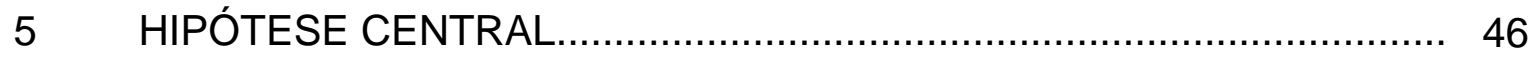

$5.1 \quad$ Hipótese complementar......................................................... 46

$5.2 \quad$ Hipótese alternativa de pesquisa................................................ 46

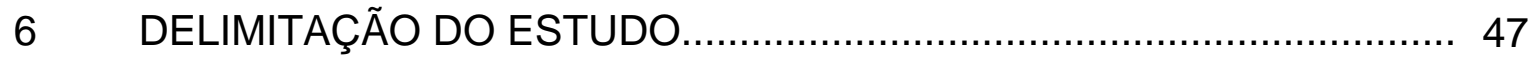

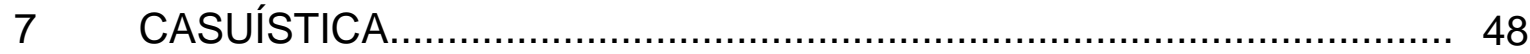

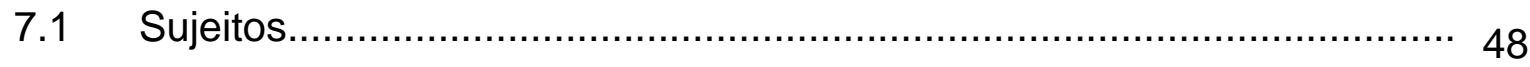

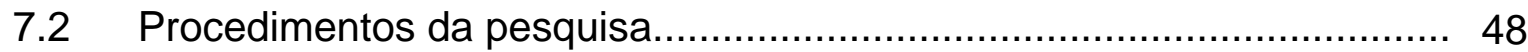

Coleta de dados............................................................. 49

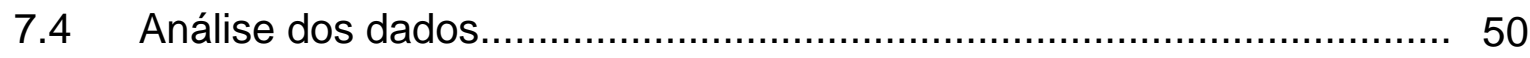

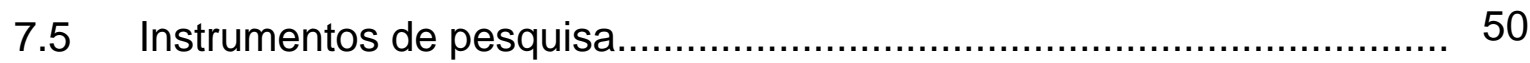

7.5.1 Espectrocolorimetro Minolta Chromameter CR 410........................... 50

7.5.2 Inventário Pratt de Crenças Religiosas no Esporte (IPCRE) .................. 51

7.5.3 Escala multidimensional de lócus de controle no esporte (EMLCE)....... 52

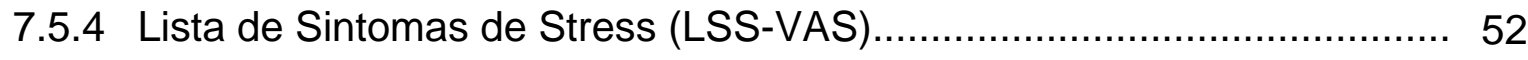

7.5.5 Nível de satisfação com a performance...................................... 53 


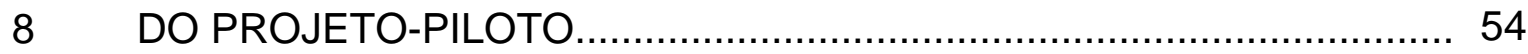

9 APRESENTAÇÃO DOS RESULTADOS ......................................... 56

9.1 Discussão dos dados dos atletas do Handebol.................................. 57

9.1.2 Caracterização das condições da coleta de dados do Handebol............ 57

9.1.3 Resultados obtidos sobre a variação da cor da pele dos atletas do Handebol pré e pós-treinos pelo método espectrofotométrico

9.1.4 Resultados obtidos sobre freqüência e intensidade dos sintomas de estresse dos atletas do Handebol pela Lista de Sintomas de Stress (LSS-VAS)

9.1.5 Análise das associações entre freqüência e intensidade dos sintomas de estresse e a variação espectral da cor da pele no rosto e braço dos atletas do Handebol.

9.1.6 Análise das correlações mais fortes obtidas entre a variação espectral da cor da pele dos atletas do Handebol $\mathrm{Db}^{\star}$ no braço e freqüência de sintomas de estresse LSS-VAS.

9.1.7 Análise das correlações mais fortes, obtidas entre a variação espectral da cor da pele dos atletas do Handebol $\mathrm{Db}^{\star}$ no braço e intensidade de sintomas de estresse LSS-VAS.

9.1.8 Análise das correlações mais fortes obtidas entre a variação espectral da cor da pele dos atletas do Handebol $\mathrm{DL}^{*}$ no rosto e freqüência de sintomas de estresse LSS-VAS.

9.1.9 Análise das correlações mais fortes obtidas entre a variação espectral da cor da pele dos atletas do Handebol DL* no rosto e intensidade de sintomas de estresse LSS-VAS. 
9.1.10 Expectativas do lócus do controle dos atletas do Handebol por meio da Escala Multidimensional de Lócus de Controle do esporte (EMLCE)..... 75

9.1.11 Análise da correlação entre lócus do controle e a variação espectral da cor da pele dos atletas do Handebol de alto desempenho.

9.1.12 Análise da associação entre lócus do controle e sintomas de estresse dos atletas do Handebol.

9.1.13 Dados obtidos sobre as crenças religiosas dos atletas do Handebol pelas questões iniciais do Inventário Pratt de Crenças Religiosas no Esporte (IPCRE).

9.1.14 Características do coping pela crença da interferência de Deus, como ajuda para superar obstáculos no esporte e a freqüência dos sintomas de estresse dos atletas do Handebol.

9.1.15 Características do coping pelo hábito dos atletas rezarem nas competições esportivas e a freqüência dos sintomas de estresse dos atletas do handebol pela LSS-VAS

9.2 Discussão dos dados dos atletas do Voleibol................................ 94

9.2.1 Caracterização das condições da coleta de dados do Voleibol.............. 95

9.2.2 Principais resultados obtidos sobre a variação da cor da pele dos atletas Voleibol pré e pós-treinos pelo método espectrofotométrico........ 95

9.2.3 Principais resultados obtidos sobre a freqüência e intensidade de sintomas de estresse dos atletas do Voleibol por meio da Lista de Sintomas de Stress (LSS-VAS).

9.2.4 Análise da associação entre freqüência de sintomas de estresse e a variação da cor da pele no rosto e braço dos atletas do Voleibol... 
9.2.5 Expectativas do lócus de controle dos atletas do Voleibol por meio da Escala Multidimensional de Lócus de Controle do esporte (EMLCE)..... 103

9.2.6 Análise da correlação entre expectativas do lócus de controle e a variação espectral da cor da pele dos atletas do 104 Voleibol.

9.2.7 Dados das crenças religiosas dos atletas do Voleibol nas questões iniciais do Inventário Pratt de Crenças Religiosas no Esporte (IPCRE).. 106

9.2.8 Freqüência de dor nas costas e o coping propiciado pela crença da interferência de Deus aos atletas do voleibol

9.2.9 Variação espectral da cor da pele $\mathrm{Db}^{\star}$ (azul-amarelo) no braço e o coping pela crença da interferência de Deus no Voleibol.

9.3 Apresentação dos dados dos atletas da Ginástica Artística.................. 118

9.3.1 Caracterização das condições da coleta de dados com os atletas da Ginástica Artística

9.3.2 Principais resultados obtidos sobre a variação da cor da pele dos atletas da Ginástica Artística pré e pós-treinos pelo método espectrofotométrico

9.3.3 Principais resultados obtidos sobre a freqüência e intensidade dos sintomas de estresse dos atletas da Ginástica Artística por meio da Lista de Sintomas de Stress (LSS-VAS).

9.3.4 Expectativas do lócus de controle dos atletas da Ginástica Artística por meio da Escala Multidimensional de Lócus de Controle do esporte....

9.3.5 Crenças religiosas dos atletas da Ginástica Artística pelo Inventário 123 Pratt de Crenças Religiosas no Esporte (IPCRE) 
9.4 Análise da variação espectral da cor da pele dos atletas da Ginástica Artística, Handebol e Voleibol e a freqüência de sintomas de estresse..

9.4.1 Associação da variação espectral da cor da pele no braço e no rosto dos atletas da Ginástica Artística, Handebol e Voleibol e a freqüência do sentimento de medo

9.4.2 Associação da variação espectral da cor da pele do braço dos atletas da Ginástica Artística, Handebol e Voleibol e a freqüência do sentimento de pavor.

9.4.3 Análise da variação espectral da cor da pele no braço e no rosto dos atletas da Ginástica Artística, Handebol e Voleibol e a intensidade dos sintomas de estresse (LSS-VAS).

9.4.4 Variação espectral da cor da pele DL (claro-escuro) rosto e o coping pela crença da ajuda de Deus para vencer obstáculos no esporte....

9.4.5 Análise do lócus de controle, variação da cor da pele e sintomas de estresse de atletas da Ginástica Artística, Handebol e Voleibol....

9.4.6 Análise das correlações entre lócus do controle e sintomas de estresse dos atletas da Ginástica Artística, Handebol e Voleibol 


\section{LISTA DE TABELAS}

Página

TABELA 1 Valores mínimos, máximos, médias e desvio-padrão da variação $L^{*} a * b *$ pré e pós-treinos no braço e no rosto dos atletas do Handebol de alto desempenho.

TABELA 2 Freqüência de sintomas de estresse de atletas do Handebol de alto desempenho por meio da Lista de Sintomas de Stress LSS-VAS.

TABELA 3 Análise de correlação da freqüência e intensidade dos sintomas de estresse e a variação espectral da cor da pele no rosto e braço dos atletas do Handebol.

TABELA 4 Expectativas do lócus de controle dos atletas do Handebol de alto desempenho.

TABELA 5 Análise de correlação entre lócus do controle e variação espectral da cor da pele dos atletas do Handebol no braço e no rosto

TABELA 6 Valores mínimos, máximos, médias e desvio-padrão da variação espectral $L^{*} a * b *$ no braço e no rosto de atletas do Voleibol.

TABELA 7 Freqüência dos sintomas de estresse dos atletas do Voleibol por meio da Lista de Sintomas de Stress LSS-VAS. 98

TABELA 8 Expectativas do lócus de controle dos atletas do Voleibol ingressantes no esporte de rendimento institucionalizado..... 103

TABELA 9 Valores espectrais da variação $L^{*} a^{*} b^{*}$ pré e pós-treinos no braço e no rosto dos atletas da Ginástica Artística................. 120

TABELA 10 Freqüência dos sintomas do estresse dos atletas da Ginástica por meio da Lista de Sintomas de Stress LSS-VAS 120 
TABELA 11 Expectativas do lócus de controle dos atletas da Ginástica Artística.

TABELA 12 Análise de correlação da freqüência e intensidade dos sintomas do estresse e a variação $L^{*} a^{\star} b^{\star}$ pré e póstreinos em medidas no braço e rosto dos atletas da Ginástica Artística, Handebol e Voleibol 


\section{LISTA DE FIGURAS}

FIGURA 1 - Os estratos morfológicos das estruturas do tecido epitelial..... 10

FIGURA 2 - Sistema de Vascularização da epiderme por artérias e veias. 11

FIGURA 3 - Faixas de absorção espectral pelo olho humano nas células cones C, M, L......................................................... 36

FIGURA 4 - Síntese aditiva e síntese subtrativa da luz......................... 37

FIGURA 5 - Dimensões espaciais da cor definidas pelo Laboratorie $d u$ Commission Internationale de I Eclairage CIE $\mathrm{L}^{*} \mathrm{a}^{\star} \mathrm{b}^{\star} \ldots \ldots \ldots .39$

FIGURA 6 - Bocal de mensuração do Chromameter CMS-35SP.............. 41

FIGURA 7 - Chromameter CR 200.......................................... 43

FIGURA 8 - Variação espectrofotométrica dos valores Db* (azul-amarelo) pré e pós treino no braço dos atletas do Handebol e a freqüência de sintomas de estresse (LSS-VAS) ....................63 63

FIGURA 9 - Disposição dos atletas do Handebol em largar o esporte e a variação espectral da cor da pele $\mathrm{Db}^{\star}$ (azul-amarelo) nas medições do braço.

FIGURA 10 - Sentimentos de pavor entre os atletas do Handebol e a variação espectral da cor da pele $\mathrm{Db}^{\star}$ (azul-amarelo) nas medições no braço.

FIGURA 11 - Associação entre Pressão orofacial e a variação espectral da cor da pele $\mathrm{Db}^{\star}$ (azul-amarelo) no braço dos atletas do Handebol

FIGURA 12 - Associação entre oscilação do apetite variação espectral Db* (azul-amarelo) em medições no braço do atletas do Handebol

FIGURA 13 - Associação das correlações mais fortes da intensidade dos sintomas de estresse (LSS-VAS) e a variação espectral Db* (azul-amarelo) no braço dos atletas do Handebol. 
FIGURA 14 - Variação espectrofotométrica DL (claro-escuro) pré e póstreinos dos atletas do Handebol e a freqüência de sintomas

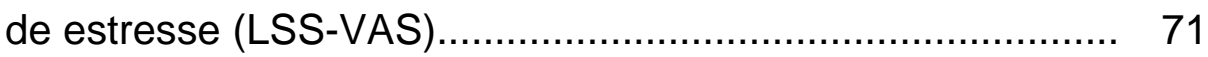

FIGURA 15 - Variação espectrofotométrica DL (claro-escuro) pré e póstreinos no rosto dos atletas do Handebol e a intensidade de sintomas de estresse (LSS-VAS) ................................. 73

FIGURA 16 - Diferentes modalidades das crenças religiosas dos atletas do Handebol com base na perspectiva da religião

FIGURA 17 - Diferentes modalidades das crenças religiosas dos atletas do Handebol sob a perspectiva da representação de Deus.

FIGURA 18 - Diferentes modalidades das crenças religiosas dos atletas do Handebol sob a perspectiva da fundamentação da crença...... 82

FIGURA 19 - Associação entre sensação de zumbidos nos ouvidos e o hábito de rezar para obter a vitória dos atletas do Voleibol de alto rendimento.

FIGURA 20 - Associação do sentimento de pavor e a variação espectral $\mathrm{Db}^{\star}$ (azul-amarelo) do braço e no rosto dos atletas do Voleibol.

FIGURA 21 - Associação do sentimento de medo e a variação espectral $\mathrm{Db}^{*}$ (azul-amarelo) do braço e no rosto dos atletas do Voleibol

FIGURA 22 - Associação do sentimento de angústia e variação espectral DL (claro-escuro), Db* (azul-amarelo) do braço e no rosto dos atletas do Handebol.

FIGURA 23 - Associação do lócus de controle pessoas poderosas e variação espectral DL (claro-escuro) do braço e rosto dos atletas do Voleibol 
FIGURA 24 - Diferentes modalidades das crenças religiosas dos atletas do Voleibol com base na perspectiva da religião.

FIGURA 25 - Diferentes modalidades das crenças religiosas dos atletas do Voleibol sob a perspectiva da representação de Deus.

FIGURA 26 - Diferentes modalidades das crenças religiosas dos atletas do Voleibol pela fundamentação da crença.

FIGURA 27 - Associação entre freqüência de dores nas costas e coping pela crença em Deus, como ajuda para vencer obstáculos no Voleibol.

FIGURA 28 - Associação entre freqüência de dores nas costas e coping da crença da interferência de Deus nas derrotas

FIGURA 29 - Associação da variação espectral DB* (azul-amarelo) e coping da crença na ajuda de Deus para vencer obstáculos no esporte.

FIGURA 30 - Diferentes modalidades das crenças religiosas dos atletas da Ginástica Artística com base na perspectiva da religião.

FIGURA 31 - Diferentes modalidades das crenças religiosas dos atletas da Ginástica Artística sob a perspectiva da representação de Deus.

FIGURA 32 - Diferentes modalidades das crenças religiosas dos atletas da Ginástica Artística pela fundamentação da crença.

FIGURA 33 - Associação entre freqüência de sintomas de estresse e variação $\mathrm{DL}^{*}$ (claro-escuro) no rosto dos atletas da Ginástica Artística e Handebol.

FIGURA 34 - Associação entre freqüência do sentimento de desempenho limitado e variação DL* no rosto dos atletas da Ginástica Artística e Handebol 
FIGURA 35 - Associação entre freqüência do sentimento de irritação e variação $D^{*}$ no rosto dos atletas da Ginástica e Handebol..... 128

FIGURA 36 - Associação entre freqüência do sentimento de pressão no peito e variação $D^{*}$ no rosto dos atletas da Ginástica Artística e Handebol.

FIGURA 37 - Associação entre freqüência da sensação de nó no estômago e variação DL* no rosto dos atletas da Ginástica Artística e Handebol.

FIGURA 38 - Associação entre freqüência do sentimento de medo e variação $\mathrm{Db}^{*}$ no rosto dos atletas da Ginástica Artística, Handebol e Voleibol.

FIGURA 39 - Associação entre freqüência do sentimento de pavor e variação $\mathrm{Db}^{*}$ no rosto dos atletas da Ginástica Artística, Handebol e Voleibol.

FIGURA 40 - Associação da intensidade de sintomas de estresse e variação espectral $\mathrm{Db}^{\star}$ no braço dos atletas da Ginástica Artística e Handebol.

FIGURA 41 - Associação da variação espectral DL* rosto dos atletas da Ginástica Artística e Handebol, freqüência de sintomas de estresse e coping pela crença em Deus como ajuda para superar obstáculos no esporte.

FIGURA 42 - Associação da variação espectral DL* rosto dos atletas da Ginástica Artística e Handebol, freqüência de sintomas de estresse e coping pela crença da interferência de Deus nas derrotas

FIGURA 43 - Associação do lócus de controle interno e compulsão dos atletas da Ginástica Artística, Handebol e Voleibol roerem as unhas 
FIGURA 44 - Associação do lócus de controle interno e sentimentos de insegurança dos atletas da Ginástica Artística, Handebol e Voleibol.

FIGURA 45 - Associação do lócus de controle interno e vontade de ficar sozinho dos atletas da Ginástica Artística, Handebol e Voleibol.

FIGURA 46 - Associação do lócus de controle externo sorte-azar e sensação de aumento dos batimentos cardíacos dos atletas da Ginástica Artística, Handebol e Voleibol

FIGURA 47 - Associação do lócus de controle externo pessoas poderosas e o cansaço dos atletas da Ginástica Artística, Handebol e Voleibol.

FIGURA 48 - Associação do lócus de controle externo pessoas poderosas sentimento dos olhos lacrimejantes e visão embaçada dos atletas da Ginástica Artística, Handebol e Voleibol

FIGURA 49 - Associação do lócus de controle interno e intensidade de sintomas do estresse dos atletas da Ginástica Artística e do Handebol

FIGURA 50 - Associação do lócus de controle externo pessoas poderosas e intensidade dos sintomas de estresse dos atletas da Ginástica Artística e do Handebol

FIGURA 51 - Associação do lócus de controle interno e uso de medicamentos pelos atletas da Ginástica Artística, Handebol e Voleibol. 


\section{LISTA DE ANEXOS}

Página

\begin{tabular}{|c|c|c|}
\hline ANEXO & 1 & - Parecer do Comitê de Ética .... \\
\hline ANEXO & II & - Termo de Consentimento Livre e Informado do técnico........... \\
\hline ANEXO & III & - Termo de Consentimento Livre e Informado do atleta............. \\
\hline ANEXO & IV & - Inventário Pratt de crenças religiosas no esporte.................... \\
\hline ANEXO & V & - Escala multidimensional de lócus de controle do esporte..... \\
\hline ANEXO & $\mathrm{VI}$ & - Lista de sintomas de Stress... \\
\hline ANEXO & VII & - Características sociotécnicas \\
\hline
\end{tabular}




\section{RESUMO}

O objetivo do presente estudo foi investigar a variação espectrofotométrica da cor da pele dos atletas de Handebol, Ginástica Artística e Voleibol nas atividades pré e pós-treinos. Como possível sinal de estados psicofisiológicos associados ao "amarelão", em decorrência do estresse do esporte de rendimento, propiciado pelo coping das crenças religiosas caracterizadas como: primitiva, intelectual, emocional e ético-moral e o lócus do controle: interno e externo: sorte-azar, pessoas poderosas. A hipótese que o ambiente do esporte constitui-se em um modelo de manifestações neuropsicológicas, bioinstintivas, psicofisiológicas, psicossociais e intrapessoais que se estrutura e desenvolve-se sinalizado por respostas dadas pelo organismo humano, ao se delinear entre os atletas e as formas de comportamentos alinhadas ao estresse e coping das crenças. Os dados foram coletados em um clube social e esportivo da cidade de São Paulo, por meio da Lista de Sintomas de Stress (LSS/VAS); Inventário Pratt de Crenças Religiosas no Esporte (IPCRE); Escala Multidimensional de Lócus de Controle do Esporte (EMLCE). As mensurações da cor da pele foram realizadas, utilizando-se o Espectrocolorímetro Minolta Chromameter CR 410 e avaliadas com base nas dimensões da cor definidas pelo Commission Internationale de E'clairege (CIE L*a*b*), conforme as dimensões: $\mathbf{L}$ (claro-escuro); $\mathbf{a}$ (vermelho-verde) e b (azul-amarelo). As variações da cor da pele denominadas no senso comum como "amarelão" foram caracterizadas no estudo pela cor da pele significativamente menos amarela no braço e menos clara no rosto (palidez), que se associou com diferentes sintomas de estresse podendo ser detectadas antes ou depois dos treinos. O estudo mostrou que o coping oferecido pela crença da interferência de Deus como ajuda para superar obstáculos no esporte é ineficiente, pois os atletas que apresentaram indícios de maior freqüência de sintomas de estresse foram os que recorreram à ajuda da intervenção divina.

Palavras-chave: esporte; colorimetria; estresse, crenças religiosas; lócus de controle 


\begin{abstract}
The purpose of the present study was investigated the spectrophotometric reflectance changes of skin colour of competitive Handball, Volleyball and Artistic gymnastic athletes before and after the trainings as possible signs of psychophysiological states associated whit the "yellow stress" due to competitive sport, propitiated for the religious coping characterized as the faiths: primitive, intellectual, emotional and ethical-moral, impacted with locus of control internal and external chance and powerful others. The hypothesis of the environment of competitive sport as model of neurophysiological, bioinstives, psychophysiological, psychosocial and intrapersonal manifestations, structured and signalized according to functional states of the human organism delineated between athletes behaviors aligned with their stress coping skills. The data were collected in a social sport club in the city of São Paulo, through the List of stress symptoms (LSS/VAS); Sport Pratt inventory of religious faiths (IPCRE); Sport multidimensional locus of control scale (EMLCE). The skin colour changes were measured with the Minolta chromameter CR 410 and evaluated in the colour space as defined by the Commission Internationale de l'Eclairage (CIE L*a*b*) according to dimensions $\mathbf{L}^{*}$ (clear-dark); $\mathbf{a}^{*}$ (red-green) and $\mathbf{b}^{*}$ (blue-yellow). The change of skin colour denominated "yellow stress" was significantly correlated with the measurements of skin colour changes before and after the trainings as less yellow in the ventral arm and less lighter in the face associates with symptoms of stress. Results also showed the coping provided for pray and faith in God to overcome sports obstacles is inefficient because athletes who presented indications of major stress symptoms appealed for divine intervention.
\end{abstract}

Word-key: sport; colorimetriy; stress, religious faiths; locus control 


\section{INTRODUÇÃO}

O tema desta tese de doutorado tornou-se realidade em conseqüência da dissertação de mestrado apresentada por CONCEIÇÃO (2004) à Escola de Educação Física e Esporte da Universidade de São Paulo, intitulada "PERFIL PERSÉFONE: UM ESTUDO SOBRE CRENÇAS RELIGIOSAS E LÓCUS DE CONTROLE DE ATLETAS DE HANDEBOL". Pesquisa que se originou das dúvidas sobre o significado das crenças, rituais e constantes referências a Deus no esporte de alto rendimento, que resultou no desenvolvimento de dois instrumentos de avaliação programados no campo da psicologia do esporte: uma escala designada para avaliar as expectativas do atleta sobre a causalidade dos acontecimentos na carreira esportiva, denominada: Escala Multidimensional de lócus de controle do esporte e um inventário designado para examinar o significado das crenças religiosas no esporte, denominado: Inventário Pratt de crenças religiosas no esporte.

O processo de adaptação e validação desses instrumentos no esporte mostrou que as crenças religiosas poderiam manifestar-se como estratégias de coping com base em mecanismo de enfrentamento ao estresse decorrente das pressões internas e/ou externas, inerentes aos desafios e adversidades do esporte de alto rendimento. Achados que se alinharam às concepções de PAIVA (1998), PORTNOI (1999), sobre as crenças religiosas como mecanismos de coping ao estresse. Assim, surgiu a intenção de pesquisar as oscilações da cor da pele que se evidenciam no "amarelão", como um possível sinalizador do estresse psicofisiológico mediado pelo coping das crenças religiosas impactadas pelas expectativas de lócus de controle dos atletas.

Para HOFFMANN, ZOGB, FLECK e MÜLLER (2005), a pele é o espelho de funcionamento do organismo, pois sinaliza nosso mundo interior. A coloração, a secreção e a temperatura podem sofrer alterações, conforme os diferentes estados afetivos. Aspectos que refletem os estados do ser psicológico e fisiológico. 
As oscilações da cor da pele alinham-se à resposta do organismo pela percepção de estímulos, como ameaçadores e a ativação do sistema nervoso simpático no sentido de mobilizar a energia orgânica para defender-se: fight-or-flight (luta ou fuga) NITSCH, ALLMER, HACKFORT, LAZARUS, MCGRATH, SELYE e UDRIS (1981). O sistema simpático possui terminações nervosas na pele, ligadas aos vasos sangüíneos que irrigam o tecido epitelial, entre os sinais característicos de sua ativação pelo senso de perigo, há a mobilização do eixo hipófise supra-renal seguida por descargas hormonais de epinefrina que são assinaladas pela dilatação da pupila, inibição do fluxo salivar, aceleração dos batimentos cardíacos, dilatação dos brônquios, contração dos esfíncteres, maior interiorização da corrente sanguínea e diminuição do fluxo sangüíneo pela vasoconstrição, sintomas de estresse que apresentam conformidade com a tese do "amarelão" no esporte.

HOUAISS (2001) distingue com poucas palavras, entre uma série rubricas de acepção biológica, o sentido do termo "amarelão", como uma locução brasileira de caráter regionalista, cuja derivação figurada do verbo "amarelar" significa ver-se em apuros, dificuldades diante de situação difícil, perder a coragem frente a condições perigosas, perder o viço - a energia vital. Reporta a origem etimológica do termo amarelo à expressão do baixo-latim hispânico, amarellus, cujo diminutivo, amarus, significa amargo.

No Medievo, o conhecimento popular aplicado àqueles que padeciam de transtornos da secreção biliar: o fel, a bile amarela ou humor amargo; substância de coloração amarela esverdeada secretada pelo fígado, que é associada ao temperamento colérico - mau humor. Concepções que se originaram das tradições hipocráticas na Antiguidade Clássica e reportam à visão holística da saúde pela integração do ser humano em seus aspectos físico e mental. Os fundamentos da teoria dos quatro humores são: sangue, bile amarela, fleuma e bile negra. Trata-se de substâncias associadas às condições psicofisiológicas. Os conteúdos psíquicos surgem como pano de fundo para os estados afetivos, resultando em alterações orgânicas. 
A ENCYCLOPAEDIA BRITANNICA (2008) lista 22 definições que são associados à yellow (amarelo), mas nenhuma exprime a idéia que o termo "amarelão" assume no esporte brasileiro. As expressões em inglês que mais se aproximariam da idéia do "amarelão" seriam: yellow panic (amarelo de pavor) ou yellow stress (amarelo de stress). Assim, no contexto deste estudo adotou-se para expressar em inglês a idéia de "amarelão" o termo yellow stress.

VYGOTSKY e LURIA (1996) destacam a importância que a linguagem pode oferecer ao desenvolvimento cognitivo das culturas. Referem que particularidades das especificidades do trabalho, adaptação e sobrevivência no contexto de determinadas culturas são invisíveis em outras, por causa da inexistência de termos e expressões correspondentes. Exemplo disso é o grande número de palavras para nomear as cores do gelo pelos povos do norte. Os signos lingüísticos do esquimó são concebidos para caracterizar sutis diferenças entre as ondas espectrais que diferenciam nuanças da cor do gelo em virtude das necessidades de sobrevivência no Pólo Norte. A distinção das cores do gelo permite diferenciar o lugar onde se pode pisar, do lugar onde se pisar afunda; assinala o lugar em que se pode encontrar caça; a cor indica o gelo que fornece água potável; a cor mostra o gelo que pode produz blocos para a construção de iglus, entre outras aplicações e condições de sobrevivência que são essenciais à manutenção da vida no Ártico.

VYGOTSKY e LURIA (1996) ressaltam que ocorre um salto de qualidade no desenvolvimento psicológico e cultural ao se introduzir o uso de instrumentos e signos de linguagem. Os instrumentos funcionam como órgãos artificiais em extensão do corpo humano, deste modo, o aperfeiçoamento dos meios produtivos. Já, os signos lingüísticos as cognições, conscientização do ambiente e da dinâmica psicológica. Assim, a possibilidade de ocorrerem o desenvolvimento da cultura e a mudança do comportamento. Daí, a importância que o controle espectrofotométrico das oscilações da cor da pele envolvidas pelo "amarelão", poderá propiciar ao atleta e ao esporte em suas dimensões múltiplas no Brasil.

Os significados envolvidos pela expressão "amarelão" contrapõem-se ao arquétipo do herói, molde psíquico dominante no imaginário coletivo que reporta à origem mítica do esporte. 
GOLDEM (1998), BRANDÃO (1998), CONCEIÇÃO (2004), assinalam que os Jogos Olímpicos teriam sido instituídos por Héracles, um herói dotado de grande força e coragem que realizou feitos incríveis, instituindo os jogos e as competições para homenagear Zeus, em agradecimento às interferências favoráveis no cumprimento dos desafios que Ihes foram impostos ao longo de sua jornada.

Não obstante, a origem mítica do esporte. No Brasil, o termo "amarelão" é uma expressão corriqueira no futebol. Modalidade que para DAMATTA (2003) insere-se no processo de construção da identidade brasileira, pois o futebol surgiria como uma instituição secundária que permite a expressão, a mobilidade e torna visível a pluralidade e a multiplicidade de cor de pele inerentes as etnias que constituem o povo brasileiro. A identificação com o jogador como artista e malandro astuto que ginga para driblar as mazelas da vida, se supera e impõe-se sobre as dificuldades do esporte. Mas, ao deparar-se com as forças incontroláveis do acaso que são inerentes ao jogo, procura expurgá-las por meio de rituais e reza!

Para CONCEIÇÃO (2004), a religiosidade do povo brasileiro faz-se presente em todas as atividades das pessoas, entre elas, o esporte. O catolicismo, no Brasil, é a religião que possui o maior número de seguidores, em virtude da colonização portuguesa. Entretanto, por vezes, a religião distancia-se dos cânones clássicos. Pois, inseriu-se no Brasil, marcada pelas crenças que povoavam o imaginário das pessoas comuns do povo português, alternadas pela magia e a bruxaria do medievo que, aos poucos, mesclaram-se ao animismo dos povos indígenas e aos cultos povos africanos e resultou no sincretismo religioso.

PRATT $(1907,1923)$ desenvolveu um questionário para pesquisar as crenças religiosas de intelectuais e figuras ilustres de sua época, fez parte desse estudo, Willian James, expoente da psicologia da religião nos Estados Unidos da América. FREITAS (2002) se baseou nos estudos realizados por James Bisset Pratt em um estudo sobre as crenças religiosas de estudantes de psicologia.

CONCEIÇÃO (2004) adaptou à área o questionário Pratt, sob a denominação: Inventário Pratt de crenças religiosas no esporte (IPCRE), que surgiu fundamentado nas pesquisas empíricas sobre crenças religiosas nos últimos 100 anos. 
Assim, as crenças religiosas foram compreendidas em quatro dimensões: crença primitiva - a crença que se insere no processo de aculturação da pessoa e continua na vida adulta como por inércia; a crença intelectual - que oscila entre a crença e a descrença e caracteriza-se pela dúvida e busca de evidências que comprovem a existência de Deus; a crença emocional - que se caracteriza pela associação da crença religiosa com a experiência vivencial, a sensação de ter vida, ou a percepção de Deus como energia; e a crença ético-moral - que se caracteriza pelo pragmatismo e busca de padrões comportamentais com base na reflexão ética sobre os grandes valores de humanidade (CONCEIÇÃO, 2004).

Neste contexto, o "amarelão" distingue-se como um possível sintoma de estresse, mediado pelo coping das crenças religiosas dos atletas impactadas pelas expectativas de lócus de controle. Fenômeno biopsicossocial inerente ao esporte de alto rendimento que se manifesta em todas as modalidades, entre as quais, 0 Handebol, a Ginástica Artística e o Voleibol. Modalidades que integram este estudo em virtude das condições que se sujeitam à pesquisa de campo, à disponibilidade dos equipamentos utilizados na mensuração da oscilação da cor da pele, à disponibilidade dos técnicos que coordenam as equipes e dos atletas em meio ao estresse, inerente do esporte de alto rendimento.

MAGNUSSON ${ }^{1}$ citado por COELHO (2002) distingue o ambiente percebido e o ambiente atual, como processos que resultam da interpretação cognitiva dos sinais do meio ambiente como potencialmente estressores, ou seja, o ambiente na percepção da pessoa (ambiente percebido) e o ambiente atual, que se constituí pelos contexto físico e sociocultural. Sob essas concepções, o foco das pesquisas a respeito do estresse e ansiedade mudou do interesse isolado pela estimulação externa para estudar como as reações do estresse podem ser eliciadas pelas expectativas do controle dos estímulos na situação estressora.

O termo expectativa designa o desejo, deriva do latim medieval expectare, a situação de quem espera por algo, a esperança que repousa em uma promessa ou probabilidade (HOUAISS, 2001).

\footnotetext{
${ }^{1}$ MAGNUSSON, D. Determinantes situacionais do stress: uma perspectiva interativa. New York: The free press, 1982.
} 
Assim, a Escala multidimensional de lócus de controle do esporte avalia as expectativas do controle dos atletas: lócus interno, quando as expectativas do controle estão voltadas ao próprio atleta; lócus externo, sorte-azar, quando as expectativas são creditadas ao acaso, destino ou à influência da sorte; e lócus externo pessoas poderosas, quando as expectativas de controle estão voltadas à influência de figuras de poder ROTTER, CHANCE e PHARES (1972), DELA COLETA $(1979,1982)$, DELA COLETA $(1987,2004)$, CONCEIÇÃO $(2004)$.

O "amarelão" consiste em um processo que seria mediado pelas crenças dos atletas que se desencadearia em situações críticas, mediante a percepção de estímulos hostis, os quais, impactam com o sentido do esporte expresso pelo fair play, como sinônimo de saúde, persistência, superação e eqüidade. Trata-se de um fenômeno que poderia ser caracterizado e dimensionado pela mensuração espectrofotométrica das oscilações da cor da pele, avaliadas pelo sistema de cor proposto pelo Commission Internationale de E'clairege nas dimensões: $L^{*}$ (claroescuro); $a^{*}$ (vermelho-verde) e b* azul-amarelo - CIE L*a*b*.

No Brasil, a psicologia do esporte ainda não tem seu espaço assegurado nos clubes e instituições esportivas. Para os conflitos psicológicos nos cenários do esporte de alto rendimento, uma das únicas vias de expressão aos técnicos e atletas é a somatização, a manifestação de uma problemática psicossocial ao fixar-se no corpo. Situações que podem representar, dependendo da importância e da natureza dos interesses postos em jogo e da ineficiência dos atletas, dor e constrangimentos às equipes e instituições que patrocinam e promovem o espetáculo esportivo.

As investigações sobre os fenômenos psicossociais que interferem no comportamento e desempenho dos atletas, em níveis individuais, grupais e institucionais têm sido foco de discussões do Grupo e Laboratório de Estudos e Pesquisas em Psicossociologia do Esporte - "GEPPSE - LAPSE", pertencente ao Departamento de Esporte da Escola de Educação Física e Esporte da Universidade de São Paulo, pois desde sua criação, em 1992, pelo Prof. Dr. Antonio Carlos Simões, vem contribuindo para a Ciência do Esporte / Área de Estudos do Esporte. 


\section{OBJETIVO GERAL}

- Investigar o "amarelão" no esporte por meio da mensuração das oscilações espectrais da cor da pele nas atividades pré e pós-treinos de atletas do Handebol, Ginástica Artística e Voleibol, como possíveis sinalizadores de condições psicofisiológicas associadas ao estresse inerente ao esporte de alto rendimento, mediado pelo coping propiciado pelas crenças religiosas: primitiva, intelectual, emocional e ético-moral; impactadas pelo lócus de controle: interno e externo: sorte-azar, pessoas poderosas.

\subsection{Objetivos específicos}

- Investigar e avaliar por meio de técnicas não invasivas as possíveis associações entre as oscilações cromáticas da pele caracterizada como "amarelão" e as disposições ao estresse por meio de itens da Lista de Sintomas de Stress (LSS/VAS).

- Investigar e avaliar as possíveis associações entre estresse, oscilações cromáticas da pele e o coping por crenças religiosas pelo Inventário Pratt de Crenças Religiosas no Esporte (IPCRE).

- Investigar e avaliar as possíveis relações entre oscilações cromáticas da pele, coping e expectativas lócus de controle, por meio da Escala Multidimensional de Lócus de Controle do Esporte (EMLCE).

- Investigar e avaliar as possíveis relações entre as oscilações cromáticas da pele caracterizadas como "amarelão" e a satisfação com o desempenho. 
O imaginário do esporte é permeado pelo arquétipo do herói DURAND (1998), CONCEIÇÃO (2004), CAMPBELL (2007), JUNG (2008). Uma força psicológica de natureza inconsciente que exerce uma profunda influência na sociedade. Pois o esporte, desde sua origem mítica GOLDEM (1998), BRANDÃO (1998), CONCEIÇÃO (2004), da Antiguidade Clássica, aos estádios da modernidade, apresenta-se associado com a crença na ajuda de Deus para superar dificuldades. Neste contexto, o "amarelão" causa perplexidade ao chocar-se com as forças do imaginário e suscita questionamentos quanto aos limites do ser humano.

O estudo da relação entre estresse e as oscilações espectrais da cor da pele de atletas caracterizadas como "amarelão" no esporte é inédito e poderá oferecer novas perspectivas ao esporte e aos estudos sobre estresse. Na verdade, a possibilidade da melhor compreensão da interação entre aspetos psicológicos (mente) e somáticos (corpo). E a possibilidade de abertura de um novo campo de pesquisa e aplicação no Brasil. Pois, os estudos a respeito da mensuração da cor da pele são realizados em países como o Japão, Estados Unidos da América e Alemanha. Porém, restritos as pesquisas em oncologia sobre a evolução do câncer de pele; mensuração da cor de cicatrizes provocadas pela modelagem do corpo em cirurgias plásticas; e estudos sobre aplicações em cosmética.

Poderá contribuir para o avanço das pesquisas em psicologia do esporte, no Brasil, por meio do controle espectrofotométrico e a avaliação do estresse pelas oscilações da cor da pele dos atletas. Uma técnica não invasiva e solução inovadora em face da complexidade envolvida na busca da equação desse fenômeno nas pesquisas sobre o estresse hormonal. Poderá se constituir como método de auxílio na preparação (física e psicológica) dos atletas. O cuidado primário na prevenção e controle do estresse no esporte de alto rendimento, pela mensuração das oscilações da cor da pele dos atletas nos treinos e nos jogos, como sinalizador de sintomas de estresse e o estabelecimento de parâmetros objetivos que possam prevenir os problemas de saúde ao se extrapolarem os limites físicos e psicológicos. 


\section{REVISÃO DE LITERATURA}

A cor é um fenômeno associado à luz, cuja percepção, envolve essencialmente questões de natureza subjetiva e cultural, que são abrangidos pelas oscilações da cor da pele evidenciadas pelo "amarelão". Daí, a necessidade do estabelecimento de padrões objetivos para estudar o fenômeno associado ao coping do estresse.

Para AMUCHÁSTEGUI (2002), o fenômeno luz-cor tem influência no comportamento ao longo da história da humanidade, que se evidenciam na atmosfera metafísica das catedrais bizantinas, criada por meio da técnica dos mosaicos nas janelas que propiciam pela luz, em determinadas horas do dia, uma atmosfera de contemplação que reporta a própria representação de Deus, em virtude do simbolismo da luz no cristianismo, que se define pelas expressões "eu sou a luz do mundo"; "aquele que me segue não andará em trevas, mas terá a luz da vida", (João 8.12).

O referido autor cita que a cor, além de seu papel pedagógico, exerce profundo fascínio no ser humano por meio das imagens do cinema e as transmitidas nos aparelhos de televisão que induzem a um estado similar ao estado do sonho, conforme propriedades intrínsecas da cor, relacionadas com a microtextura das superfícies envolvidas pelo fenômeno de absorção e reflexão da luz, em virtude do grau de brilho, transparência, opacidade, entre outras propriedades, produzem diferentes "cesías"” CAIVANO, MENGH e LADISERNIA (2006); CAIVANO (2008).

No esporte, a influência pela cor é dramática, pois está fortemente vinculada com respostas de conteúdo emocional. Em última instância, é o que define a identidade dos clubes e das agremiações. Neste contexto, o "amarelão" apresentase como metáfora do medo, diante dos desafios e dificuldades próprias ao esporte e à vida, de modo geral. Suscita questionamentos sobre o coping propiciado pelas crenças religiosas, impactadas pelo lócus de controle dos atletas, que se evidencia

\footnotetext{
2 J. L. Caivano é presidente da International Colour Association (AIC) entidade que congrega grupos de estudos e pesquisas sobre cor em diversos países, entre os quais, no Brasil, a Associação Pró-cor do Brasil, que organizou em 2008 o IV Encontro Brasileiro da Cor, ocasião em que Caivano falou sobre seu conceito "cesias". O fenômeno "cesías" chama atenção para variações de características da pele, tais como: textura, brilho, transparência e opacidade.
} 
diante da luz, mediante oscilações cromáticas do tecido epitelial, como processo biopsicofisiológico em conexão com sintomas de estresse.

Daí, a complexidade dos aspectos subjetivos e culturais envolvidos pela percepção de uma situação como ameaçadora. O "amarelão" que evidencia-se pela luz, em virtude da quantidade de melanina e oscilações do fluxo sangüíneo pelos vasos que irrigam o tecido epitelial, conectados por terminações nervosas ao sistema nervoso simpático.

Nesse enigma, as oscilações da cor da pele em situações ameaçadoras, remetem ao mimetismo no percurso filogenético / ontogenético ${ }^{3}$. Assim, diante da inexistência de estudos e de dados sobre o "amarelão" e a fragmentação dos conceitos pela literatura, houve-se por bem organizar a revisão literária deste estudo por tópicos, a saber:

\subsection{Cromatismo epitelial, aspectos morfológicos e a interação da pele com sistema nervoso}

A pele é a estrutura que delimita o interno e o externo, o órgão com a maior extensão no corpo humano e está situada sobre a hipoderme que tem por funções: o isolamento térmico, o amortecimento contra golpes e o armazenamento de energia. Apresenta indícios de interação entre os aspectos psicológicos (mente) e somáticos (corpo), essenciais ao bom desempenho no esporte. Na base do folículo piloso, encontram-se as extensões de terminações nervosas, vasos sangüíneos e vasos linfáticos, ligados ao sistema nervoso central por meio de um sistema de aferência e eferência, envolvido na captação de sinais internos e externos pelo sistema nervoso periférico que são determinantes do sucesso no esporte.

O tecido epitelial é formado pela estratificação de camadas celulares, distribuídas pela epiderme e a derme, que formam uma couraça protetora contra ferimentos, invasão de agentes patogênicos e substâncias nocivas. Por isso, exerce

\footnotetext{
${ }^{3}$ Ernst Haeckel introduziu no âmbito da teoria evolucionista das espécies o conceito do desenvolvimento humano da fase embrionário ao ser adulto como potencial, pois seria um processo que se reporta a herança filogenética vinculada ao percurso ontogênico do indivíduo - Encyclopaedia Britannica (http://www.britannica.com/EBchecked/topic/251305/Ernst-Haeckel)
} 
uma função importante na defesa imunológica do organismo, cuja eficiência do sistema depende do bem-estar psicológico e social (SEER'S WEB-BASED TRAINING MODULES, 2008).

A pele integra o sistema perceptivo dos estímulos provocados pela pressão, temperatura, vento, espaço, entre outros estímulos internos, cuja percepção é essencial ao domínio dos gestos técnicos do esporte. Em conformidade com o nível de atenção são eliciadas reações instintivas e/ou ativadas as redes neurais LEDOUX (1998), em conexão com as experiências anteriores no esporte.

A cor da pele é, essencialmente, determinada por dois pigmentos, de origem protéica: a melanina e a hemoglobina. A melanina confere a pigmentação que caracteriza as diferentes tonalidades da cor da pele, de acordo com os determinantes filogenéticos e ontogenéticos ligados à etnia e à ancestralidade dos indivíduos. Sua função é absorver parte da radiação solar, especialmente, na faixa espectral de comprimento inferior a $380 \mathrm{~nm}^{4}$ que caracterizam o ultravioleta pela alta freqüência em razão do baixo comprimento de onda, como energia potencialmente danosa às estruturas da pele.

A melanina é secretada pelas células melanócitas em um processo denominado melanogênese, que é intermediado por um receptor transmembrana que se liga ao hormônio melanócito-estimulante (MCIR), depositado em vesículas, os melanossomas, que se difundem pelo estrato córneo são fagocitados pelos queratinócitos (SEER'S WEB-BASED TRAINING MODULES, 2008).

Na cútis, as extensões do sistema neuroendócrino envolvem a intermediação pelos hormônios que circulam nos vasos sangüíneos em mecanismos de ativação e feed back. As glândulas sudoríparas têm participação ativa na reação ao estressor, envolvem o controle da temperatura corporal e atuam na reorganização do todo orgânico em face da necessidade de gerar energia e concentrar as funções orgânicas e psíquicas na reação ao estressor (VASCONCELLOS, 1985).

\footnotetext{
${ }^{4} \mathrm{Nm}$ (nanômetro) unidade de medida do comprimento das ondas eletromagnéticas, um nanômetro equivale a bilionésima parte de um metro, ou $10^{-9} \mathrm{~m}$. O espectro visível compreende ondas de comprimento que variam entre 400 a $750 \mathrm{~nm}$. Os comprimentos de ondas inferiores a $400 \mathrm{~nm}$ são invisíveis ao olho humano e compreendem o ultravioleta - energia que possui alta freqüência em virtude dos baixos comprimentos de onda, o que resulta em alto poder de penetração na pele. Já os comprimentos de onda superiores a $750 \mathrm{~nm}$, também, são invisíveis ao olho humano e compreendem o infravermelho (calor), as ondas de rádio e as ondas de televisão.
} 
HOFFMANN, ZOGB, FLECK e MÜLLER (2005), referem que a pele reflete o funcionamento do organismo por meio de sinais, pois o aspecto, a coloração e a secreção sofrem oscilações conforme os estados afetivos. Citam Dethlefsen e Dalke, em referência aos estudos realizados por C. G. Jung, quanto à técnica de associação de palavras com a mensuração da resposta galvânica da pele (atividade bioelétrica da pele mediada pelos íons dos sais presentes no suor), é possível medir na atualidade, tendo em vista a maior precisão dos instrumentos graças à evolução tecnológica dos equipamentos eletrônicos, para medir contínuas e sutis variações da atividade elétrica da pele.

Os vasos sangüíneos, as glândulas sudoríparas e o pelos são inervados por terminações nervosas do sistema nervoso simpático que constituem estruturas responsáveis por noções essenciais ao domínio do gesto técnico, afetados por distintos estados psicológicos na tentativa do domínio sobre o ambiente-tempoespaço. Estas estruturas são ilustradas pela FIGURA 1.

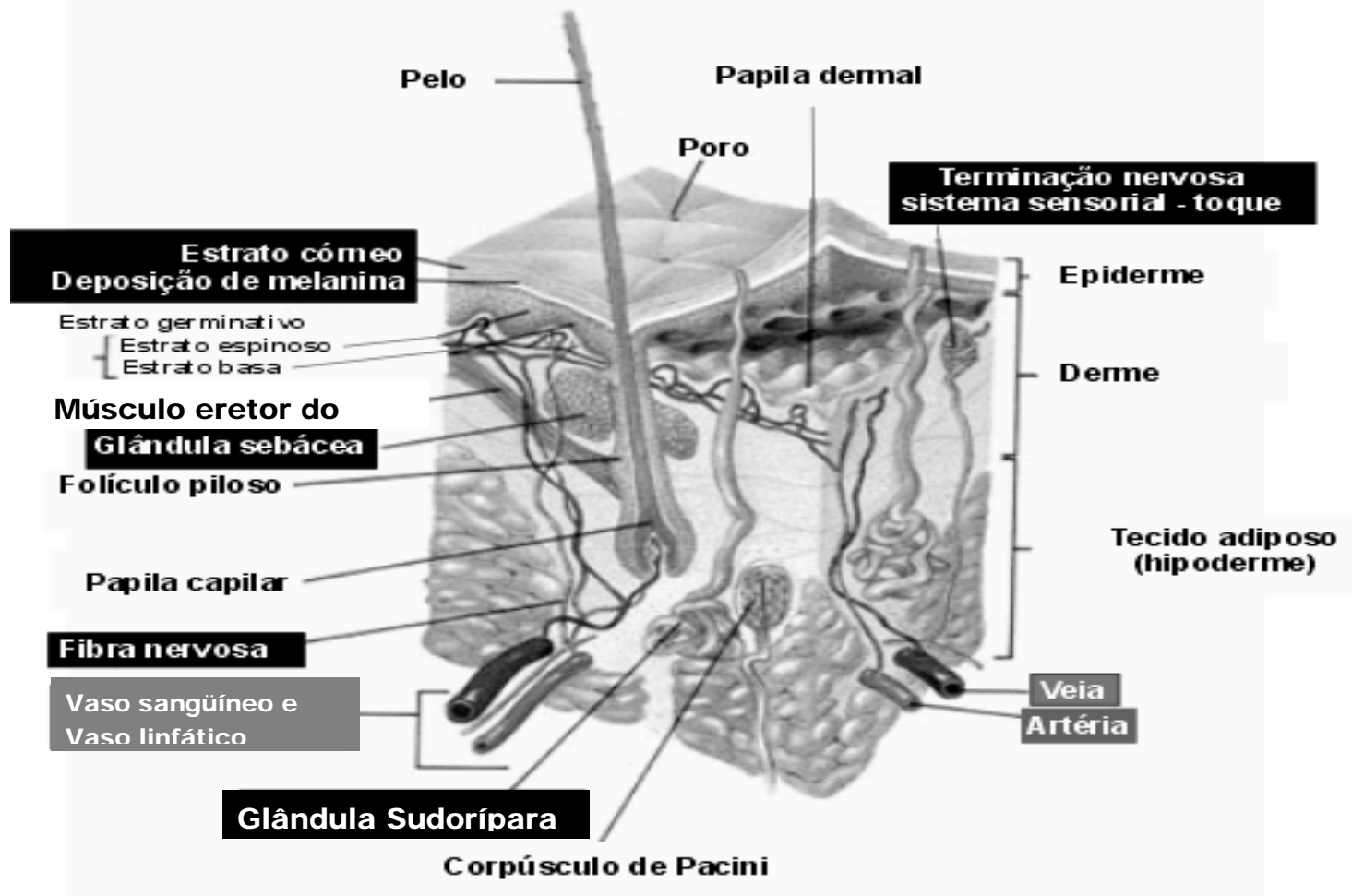

FIGURA 1 - Os estratos morfológicos das estruturas do tecido epitelial (Fonte: UNITED STATES GOVERNMENT, 2008) 
A FIGURA 1 revela terminações nervosas e glandulares que configuram a pele, como a parte mais visível do sistema nervoso. O estrato córneo, camada mais externa, que faz a interface com o ambiente, consiste na deposição de queratina, óleos graxos e células mortas. A derme é o tecido que dá sustentação ao sistema de veias e artérias que vascularizam a pele e transportam o oxigênio necessário às divisões celulares, diferenciação e crescimento de novas células e síntese de melanina, o pigmento de cor castanho que caracteriza as diferentes tonalidades da cor da pele.

As artérias que compõem o sistema vascular da pele, também, são responsáveis pela transmissão de hormônios e sinais químicos emitidos pelas glândulas cutâneas, tendo em vista o sistema de vascularização da pele, conforme é esquematizado pela FIGURA 2.

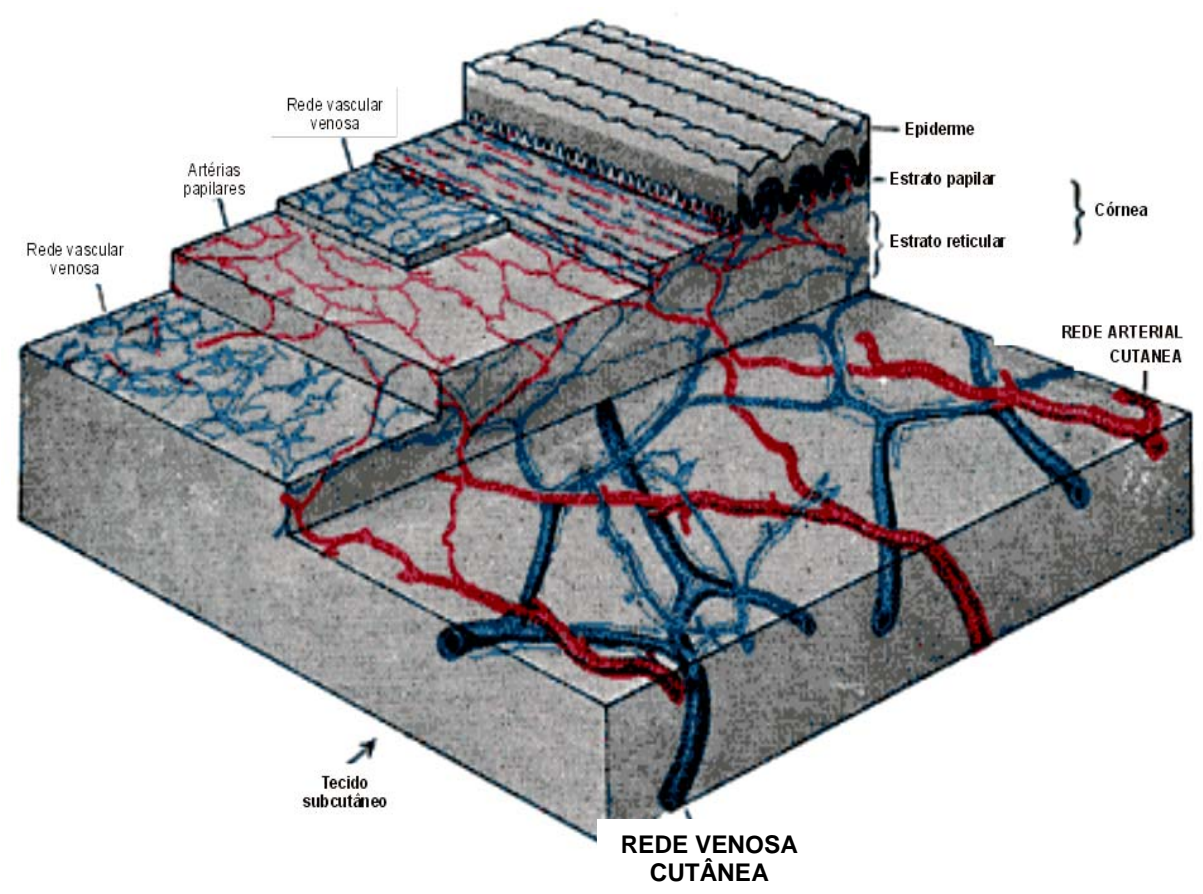

FIGURA 2 - Sistema de vascularização da epiderme por artérias e veias

(Fonte: GRAY'S ANATOMY OF THE HUMAN BODY, 1918) 
O sistema de vascularização da pele, conforme a FIGURA 2 representa um conjunto que pulsa em conexão com as avaliações perceptual-cognitivas das situações nas quais os indivíduos se inserem. Um movimento de expansão e contração de artérias e veias faz com que a cor da pele oscile em virtude da vasoconstrição como resposta do organismo à percepção de estímulos estressores.

\subsection{O estresse e o mimetismo no processo evolutivo}

As disposições de natureza instintual contextualizadas no processo evolutivo submetem todo ser ao jugo imperativo de duas forças: manter-se vivo e reproduzir a vida. Assim se instauraram as exigências de competição, que são intensificadas pelo conflito na disputa por recursos escassos, um verdadeiro jogo de astúcias, agilidade, sorte e força. Neste contexto, as oscilações da cor da pele envolvidas pelo mimetismo ${ }^{5}$ revelam-se como estratégias de ilusionismo defensivo ou ofensivo, capaz de driblar os sistemas de ataque e defesa dos outros seres vivos. Mas, acaba por iludir o próprio ser, o auto-engano, como refere (GIANNETTI, 1998).

Os estratagemas miméticos das plantas e insetos ampliam-se em direção aos primatas inteligentes (GIANNETTI, 1998). Envolvem respostas de natureza instintiva, entre as quais, poder-se-ia incluir o "amarelão" em virtude da constrição do fluxo sangüíneo como mecanismo de defesa que previne contra ataques e ferimentos. As estratégias ostensivas de mimetismo ofensivo pelo uso de cores chamativas para destacar superioridade e poder. O mimetismo por ocultação, que se apóia na camuflagem como um meio para tornar-se pouco visível em ambientes hostis. $E$ as estratégias de mimetismo por desinformação ativa, baseadas em práticas, como o blefe, por meio da manipulação da atenção. Exemplo notável de determinados pássaros da fauna brasileira que se camuflam, mas, ao serem surpreendidos exibem um forte colorido, antes ocultado pelas asas fechadas, ao serem abertas impregnam a retina do agressor com um forte colorido e em seguida, somem na paisagem.

\footnotetext{
${ }^{5}$ No contexto deste estudo, o mimetismo é concebido em associação com as oscilações de cor da pele vinculadas ao estresse no campo da psicologia analítica, como manifestação de determinantes arquetípicos e disposições inatas que seriam possíveis de serem representadas por meio de símbolos, entre os quais, a cor, que envolve aspectos inconscientes, possíveis de serem conscientizados, pensados, analisados e até mesmo modificados por meio de cognições ou de novas cognições.
} 
GIANNETTI (1998) considera difícil saber até que ponto os engano e autoenganos que implicitamente associam-se ao mimetismo resultam da herança genética, pressão do ambiente, aprendizado ou da combinação desses três aspectos. Cita Schopenhauer ${ }^{6}$ em oposição à visão romântica da natureza como fonte de ética, sabedoria e virtude, referindo-a como "campo de batalha de seres atormentados e agonizantes que continuam a existir, apenas devorando-se uns aos outros". Assim, o homem reflete sua natureza selvagem, em meio a uma série intrincada pelo mimetismo - enganos e auto-enganos fundamentados no medo e na angústia existencial.

Os estudos sobre estresse com animais envolvem a observação do comportamento em situações críticas; os testes com drogas e medicamentos para controlar dor e ansiedade; e até mesmo, exposição a agentes exógenos VAN DER SALM, SPANINGS, GRESNIGT, WENDELAAR BONGA, FLIK (2005), realizaram experimentos sobre estresse no ambiente aquático e as oscilações da cor do oreochromis mossambicus (tilápia), mediante à acidulação da água e a exposição continua ao agente químico estressor $\left(\mathrm{H}^{+}\right)$, a cor do peixe ficou mais clara a medida se reduz o pH da água do aquário.

KORZAN, SUMMERS e SUMMERS (2002), experimentos sobre o estresse social e o cromatismo do anolis carolinensis, uma espécie de camaleão, que é normalmente verde, mas muda de cor em situações de estresse e torna-se amarelado, a pálpebra vai ficando mais escura, simulando grandes olhos miméticos, por meio de alterações hormonais no eixo adrenal-catecolamínico, mediadas pelos receptores beta (2) adrenérgico.

Os pesquisadores verificaram que a oscilação da cor da pálpebra do anolis carolinensis influenciava a hierarquia social de dominância entre os machos, sob a hipótese de que a cor mais escura da pálpebra comunicaria um sinal de dominância. Realizaram um estudo experimental que envolveu uma espécie de disputa entre lagartos machos, que foram selecionados, conforme o peso e o tamanho, mas, com diferentes cores das pálpebras (verdes $\mathrm{x}$ pretos) e colocados em um espaço restrito.

\footnotetext{
${ }^{6}$ A. SCHOPENHAUER. The World as Will and representation [O mundo como desejo e representação]. Trad. E. Payne. Nova York, 1969.
} 
KORZAN, SUMMERS e SUMMERS (2002) verificaram que, em situações de estresse, os machos com pálpebras escuras agiam de forma mais agressiva, pois se aproximavam do opositor mordendo agressivamente. Assim, determinou-se a hierarquia de dominância de um macho sobre o outro cujos critérios foram postura imponente, o recuo do oponente e a constatação da oscilação da coloração, visivelmente em relação às pálpebras mais claras - esverdeadas.

Os machos com manchas pretas na região orbital interagiram de forma mais agressiva, constatando-se $100 \%$ de dominância. Apenas a percepção das manchas escuras nos olhos dos oponentes provocou nos animais com pálpebras mais claras elevação dos níveis plasmáticos de epinefrina, noraepinefrina e dopamina, comparados ao grupo controle, concluindo-se que a cor das manchas na região orbital do anolis carolinensis constitui um estímulo social potente.

\subsection{Conceitos básicos do estresse na física}

Estresse é um termo originário da física, vem do inglês stress para denominar grau de alteração do arranjo estrutural da matéria, como decorrência das condições do processo de desgaste natural ou condição de trabalho intensa. Por exemplo, ao aplicar-se força sobre um elástico ${ }^{7}$, verifica-se o alongamento (stretch). Depois de retirada a força, o elástico deveria recuperar a forma original, porém a sobrecarga modifica as estruturas da matéria em uma escala que vai da deformidade ao rompimento. O estresse é representado pela deformidade da matéria pela diferença entre o comprimento depois de retirada a força e o comprimento original.

\footnotetext{
${ }^{7}$ Metáfora do elástico em associação ao estresse - exemplo utilizado pelo prof. Dr. Esdras Guerreiro Vasconcellos nas aulas do curso de Pós-Graduação do Departamento de Psicologia social e do Trabalho na disciplina Conceito básicos de stress e sua experimentação clínica no campo da psicologia social - USP.
} 


\subsection{Conceitos básicos do estresse biológico e coping}

NITSCH, ALLMER, HACKFORT, LAZARUS, MCGRATH, SELYE e UDRIS (1981) atribuíram a Cannon (1914a, 1914b, 1929a, 1929b, 1932, 1935) ; um professor do departamento de fisiologia da Harvard Medical School, o mérito de ter introduzido no campo da ciência o conceito de estresse na relação do corpo (somático) com as emoções (psicológico) - o estresse psicossomático. Cannon idealizou uma série de estudos e experimentos com agentes estressores, e vinculou o conceito de estresse com a noção de equilíbrio biológico. Este é definido pelo conceito de homeostase ${ }^{9}$, termo de etiologia grega: homo (igual) - estase (estado), que concebe o organismo humano como um sistema (fechado/aberto) em equilíbrio dinâmico, regulado por mecanismos de feedback que controlam a estabilidade das condições metabólicas: temperatura, quantidade de água, níveis de concentração de sais, açúcares, entre outros nutrientes e condições metabólicas. Nesse contexto, Cannon propõe o conceito de estresse psicossomático em relação ao meio socioambiental, como um processo resultante de uma série de reações não específicas do organismo a diferentes estímulos, tanto internos como externos.

SELYE (1936a; 1936b; 1937; 1946; 1952 e 1956) ${ }^{10}$ citado por NITSCH; ALLMER, HACKFORT, LAZARUS, MCGRATH, SELYE e UDRIS (1981) refere que sem reduzir a importância de Cannon; é ao químico, médico e pesquisador da Johns

\footnotetext{
${ }^{8}$ W. B. CANNON, The interrelations of emotions as suggested by recent phisiological researches. Amer . J. Phychol., 1914 (a).

W. B. CANNON, The emergency function of the adrenal medulla in pain and in the major emotions. Amer . J. Physiol., 1914 (b).

9 W. B. CANNON, Organization for physiological homeostasis. Physiol. Rev. 1929.

W. B. CANNON, Bodily changes in pain, hunger, fear and rage. Boston: Branford, 1929.

W. B. CANNON, The Wisdon of the body. Chicago: Norton, 1932; 1963.

W. B. CANNON, Stress and strains of homeostasis. Amer. J. med. Science, 1935.

${ }^{10}$ H. SELYE, A syndrome produced by diverse nocuous agents. Nature, 1936 (a).

H. SELYE. Thymus and adrenals in the response of the organism to injuries and intoxications. Br. J. exp. Path., 1936 (b).

H. SELYE, Studies on adaptation syndrome. Endocrinol, 1937, 21,169 - 188.

H. SELYE, The general adaptation syndrome and the diseases of adaptation. J. clin. Endocrinol, 1946.

H. SELYE, The history of adaptation syndrome. Montreal: Acta Inc., 1952.

H. SELYE, The Stress of Life. New York.: McGrall-Hill 1956, 1976.
} 
Hopkins University, H. Selye, que se deve a conceituação do estresse no contexto das pesquisas endocrinológicas. O pesquisador relacionou os sintomas de estresse à síndrome que resulta da exposição do organismo a agentes estressores, assim, deduziu o conceito de Síndrome da Adaptação Geral (SAG), por meio da similaridade encontrada no registro comportamental de animais expostos a agentes estressores, concomitante a injeção de extratos hormonais.

A analogia dos estudos com animais com as diversas patologias encontradas no organismo humano, levou ao conceito da síndrome morfológica: degeneração do timo, crescimento do córtex da glândula supra-renal, sangramentos no estômago e duodeno, como reações do organismo à exposição prolongada a agentes estressores pela ativação do eixo hipófise/supra-renal. Nesse contexto, explicou a reação do organismo ao agente estressor em fases - a tríade do estresse, no âmbito do conceito de síndrome geral da adaptação (SAG), definidas em: reação de alarme, fase de resistência e de exaustão ou esgotamento, descritas a seguir.

- Primeira fase - Reação de alarme: caracteriza-se pelo choque causado pela identificação ou tomada de consciência de estímulos, como algo nocivo (agente estressor). A percepção ativa o eixo hipófise supra-renal e mobiliza o sistema nervoso simpático, que de modo geral, estimula ações que mobilizam energia, que são sinalizadas pelo aumento da freqüência cardiorrespiratória, sudorese, dilatação da pupila, contração dos esfíncteres, e a vasoconstrição, entre outras reações orgânicas, que sinalizam o aumento dos níveis de epinefrina na corrente sangüínea, como condição necessária à produção da energia necessária a resposta: fight-orflight (luta ou fuga).

A vasoconstrição em situações que ameaçam a integridade do organismo é uma reação orgânica tão potente que existem relatos de pessoas que sofrem ferimentos, mas não sangraram e só percebem os ferimentos depois de um determinado tempo. Por causa da diminuição do fluxo sangüíneo e a maior interiorização sistema arterial, a palidez que caracteriza o "amarelão" em conexão com o medo. Sentimento que no esporte, em maior ou menor intensidade, está associado ao perigo de lesões e a própria possibilidade de permanência nas equipes. 
- Segunda fase - resistência: se após as reações características da fase de alarme (ataque ou fuga), o agente estressor persistir, o organismo humano passará a funcionar em um patamar energético mais elevado, que se caracterizará pela ativação contínua do sistema nervoso simpático. Entretanto, o organismo humano, assim como as máquinas não pode funcionar indefinidamente em patamares energéticos muito acima de parâmetros regulares. Por isso, a fase de resistência é um estado que exige a adoção de estratégias de coping, ou seja, meios que permitam administrar o estresse para reduzi-lo ou que possibilitem a tolerância.

Neste contexto, enunciam-se as hipóteses do presente estudo sobre a interação do estresse do esporte de alto rendimento e o coping propiciado pelas crenças religiosas, impactadas pelo lócus de controle dos atletas, que se formulam com base nos estudos de PAIVA (1998), PORTNOI (1999), CONCEIÇÃO (2004) sobre a interação das crenças religiosas com estratégias de coping.

- Terceira fase - exaustão ou esgotamento: é o estágio que se caracteriza por uma eventual volta às condições originais do estado de alarme, como uma tentativa de buscar no organismo mais energia para enfrentar os perigos representados pelo agente estressor, que resultam nos sintomas clássicos de estresse, inflamações e sangramentos no estômago, depressão do sistema imunológico, surgimento de doenças mentais e, até mesmo, a morte.

NITSCH, ALLMER, HACKFORT, LAZARUS, MCGRATH, SELYE e UDRIS (1981) observam que $\mathrm{H}$. Selye, ao longo do tempo, reformulou o conceito de síndrome de adaptação geral (SAG) pela diferenciação entre os efeitos estressores, que são inerentes a todas as ações, os efeitos específicos em decorrência de estímulos específicos ou localizados e os sintomas do estresse.

LAZARUS ${ }^{11}$ citado por LIMONGI FRANÇA e RODRIGUES (2005) relaciona o estresse aos processos cognitivos, consideram que o estudo dos agentes estressores não é muito útil para compreender o fenômeno, pois seria a avaliação que o sujeito faz do ambiente e dos agentes estressores que poderiam desencadear diferentes reações em distintos sujeitos.

\footnotetext{
${ }^{11}$ R. S. LAZARUS; S. FOLKMAN. Estrés y processos cognitivos. Barcelona: Martínez Roca, 1986.

R. S. LAZARUS; S. FOLKMAN. Stress, appraisal and coping. New York: Springer, 1984.
} 
GOLDBERGER e BREZNITZ (1986) definem o estresse situacional como um conceito ligado à pessoa. Em um sentido amplo, seria o conjunto de reações psíquicas e somáticas de um indivíduo às demandas que atingem ou excedem seus limites de coping. O estresse seria decorrente da vulnerabilidade do indivíduo, definida pelas predisposições psicológicas, avaliações perceptual-cognitivas e o coping como competência para lidar com a situação.

WEITEN, LLOYD, DUNN e HAMMER (2008) revelam estratégias de coping que se aproximam de algumas técnicas utilizadas no esporte no Brasil, de modo esporádico. Observam que as pessoas tendem a utilizar basicamente três mecanismos de coping: a avaliação cognitiva, o foco no problema, o foco na emoção ou uma mistura desses três tipos. Revelam que os homens preferem estratégias de coping com foco no problema, e as mulheres tendem a utilizar o coping com foco na emoção. As estratégias de coping são descritas, a seguir:

- Coping pela avaliação cognitiva - é a estratégia cujo foco está voltado para a modificação dos modos ou das formas de pensamento (cognitivo). Seu objetivo é o desvio do foco da atenção para o estressor pela modificação de seus objetivos ou modificação de valores, por exemplo, encontrar meios para se divertir.

- Coping pelo foco no problema - é a estratégia cujo objetivo é encontrar meios que permitam lidar melhor com situação e os problemas causados pelo estressor. Por exemplo: buscar por informações que ajudem a lidar com a situação; técnicas que permitam minimizar os efeitos causados pelo agente estressor; reorganizar o modo de vida. De tal modo, permitir uma melhor adaptação à situação.

- Coping pelo foco na emoção - envolve técnicas e procedimentos de relaxamento sistemático; yoga; meditação ou meios que potencializem a pessoa para lidar melhor com os sentimentos hostis do medo, a raiva, a agressividade e a culpa, entre outros.

VASCONCELLOS e DE ROSE (1991) afirmam que o esporte de competição de alto nível exige dos atletas comportamentos característicos do Tipo A. Em pesquisa realizada com a Seleção Brasileira Feminina de Basquete que conquistou a medalha de ouro nos jogos Pan-americanos de Havana, foram analisados 0 
espírito competitivo, a pressão de tempo, a capacidade de decidir rapidamente e a exigência de sucesso, colocando em perspectiva o lócus de controle "sorte/azar", "pessoas poderosas" e "self", que explicaram, respectivamente 13\%, 12\% e $75 \%$ do sucesso ou insucesso no esporte de alto nível de competição.

Selye citado por NITSCH, ALLMER, HACKFORT, LAZARUS, McGRATH; SELYE e UDRIS (1981) mostram que as reações típicas ao estresse podem ser provocadas, tanto por situações desagradáveis (distresse) como por situações agradáveis (eustresse). VASCONCELLOS (1985) concebe os sintomas de estresse no contexto do modelo psiconeuroimunológico que podem ser desencadeados, tanto por fatores positivos (viagens, promoções no trabalho, férias, casamento) como por fatores negativos (morte, desemprego, separação, entre outros. Em um processo involuntário, mas, que pode ser intermediado: intensificado ou abrandado pela ação do aparelho psíquico, por meio de avaliações cognitivas, ou seja, a idéia da avaliação que fazemos do estresse está ligada ao modo como o agente estressor é percebido.

VASCONCELLOS (1985) afirma que as reações do organismo características da síndrome geral da adaptação, tais como: a taquicardia, a sudorese, a dor de cabeça e a pressão alta podem ser sinais de reações saudáveis do organismo e serem caracterizadas como eustresse, desde que o organismo possa retornar ao equilíbrio homeostático.

DE ROSE (1996) investigou extensivamente os sintomas de estresse no esporte infanto-juvenil e afirma que o estresse está presente em qualquer nível de competição esportiva e em qualquer idade. Pois exige foco, preparação adequada e dedicação para atingir os objetivos. E assume aspecto negativo quando existem pressões externas (técnico, torcida e companheiros) e internas (as expectativas).

Identificou 111 diferentes sintomas de estresse pré-competitivo, entre os quais são destacados no âmbito desta revisão de literatura, os aspectos que, de alguma forma, podem estar relacionados com alterações cromáticas do tecido epitelial: palidez, manchas na pele, taquicardia, cansaço exagerado ao final do treino, arrepios, calafrios, mãos frias, pés frios, febre, perda da noção do espaço, medo generalizado, medo de perder, medo do adversário, medo de errar, medo de jogar mal, medo de decepcionar as pessoas, medo de se machucar, medo de críticas, vergonha em 
perder. Entre outros aspectos, que estão em conformidade com os dados encontrados na literatura internacional, infere que não há diferenças nos sintomas estresse onde quer que as pesquisas e competições se realizem e coloca em perspectiva o potencial de aplicação desse estudo.

LIMONGI FRANÇA e RODRIGUES (2005) definem o eustresse, como o fascínio pelo estresse, o gosto pela tensão para a competitividade, o revigoramento e o prazer de estar engajado em um trabalho, pelo engajamento social e a atitude empreendedora. Já, o distress é definido como uma sobrecarga pessoal e profissional, que provoca o envelhecimento precoce, a desorganização do projeto de vida, o trabalho compulsivo e a eclosão de doenças.

O estresse é o estado relacionado ao esforço de buscar alguma coisa em situações que a pessoa percebe o ambiente ameaçador às suas necessidades de realização pessoal e profissional. Uma vez que as demandas são excessivas ou o ambiente exige, mas não fornecem recursos adequados para enfrentar a situação.

Neste continuum, o burnout surgiria como um dos desdobramentos mais importantes dos mecanismos envolvidos pelo estresse na definição dos autores do termo, a psicóloga social Cristina Maslach e o psicanalista Herbert J. Freudenberger citados por LIMONGI FRANÇA e RODRIGUES (2005).

COELHO (2002) cita que as pesquisas realizadas em campo podem revelar aspectos mais relevantes para a compreensão do estresse, pois os estudos realizados em laboratório são válidos apenas no contexto em que são desenhados e não podem ser extrapolados.

A pele revela intersecção entre aspectos psicofisiológicos e psiconeurológicos que poderiam ser sinalizados pelas variações da cor do tecido epitelial pelo método espectrofotométrico e contribuir para instrumentalizar a psicologia do esporte, dado ser um campo incipiente no Brasil, onde os atletas são constantemente confrontados com seus limites nas competições.

LIPP (2008) relata que os estudos e pesquisas mais relevantes que resultaram da intersecção da psicologia com a cardiologia, foram incorporados à edição das: V diretrizes para o tratamento da hipertensão arterial no Brasil. 
Refere a necessidade das pessoas hipertensas passarem pelo treino de controle das cognições, diante da constatação da eficácia do treino cognitivo, concomitante ao controle da freqüência cardíaca, pela exposição controlada do paciente a estímulos percebidos como estressores no contexto de vida do paciente. Tratamento que foi incorporado com sucesso ao tratamento da redução da reatividade cardiovascular de pacientes hipertensos. Realidade que se encontra muito distante do esporte, pela constatação da frágil inserção da psicologia nessa área.

\subsection{A pele como espaço de manifestações psicossomáticas}

As tatuagens, piercings, marcas e sinais que os atletas exibem em seus corpos, evidenciam que a pele é um espaço de manifestações simbólicas que revela por meio das cicatrizes, da forma, da textura e da cor os estados do interior. A maioria dos estudos sobre a relação mente-corpo e pele envolve quadros dermatológicos associados à condições psicológicas. A manifestação das doenças que surgem ou agravam-se, após a vivência de situações de estresse por traumas e perdas, por exemplo, o vitiligo (manchas brancas que surgem pelo corpo em decorrência da despigmentação da pele e que estigmatizam socialmente a pessoa pelo aspecto característico). Doenças psicossomáticas, associadas a quadros da problemática psicológica, cuja etiologia nos leva às relações primárias com mães inadequadas, figuras parentais ausentes ou super protetoras SANT' ANNA, GIOVANETTI, CASTANHO, BAZHUNI e LA SELVA (2003).

Observam que, em todas as culturas, as doenças que são estigmatizadas, ocupam um lugar no imaginário que vai muito além do perigo que efetivamente representam, pois cumpririam um papel simbólico, já que thes são imputados aspectos negados ou contrários à consciência coletiva.

O esporte de alto rendimento é uma dessas atividades que representa no imaginário a negação da doença e dos limites humanos, pois sob o domínio do arquétipo do herói, constitui-se como modelo profundamente enraizado na cultura que se resume na expressão: vencer a qualquer custo! 
Paradoxalmente, o esporte, gera um modelo que estimula o estresse, a doença do século é associada ao surgimento de uma série de outras patologias, cuja prevenção não se insere no paradigma do modelo curativo da saúde. Na atualidade, incompatível com a realidade das previdências sociais no mundo inteiro, sobrecarregadas pela demanda de populações que envelhecem e vivem mais. Porém, com pouca saúde, pois "se estouram" durante a fase produtiva de suas vidas. Aspectos que se inserem naquilo que DELA COLETA (2004) identifica como Lócus Externo da Saúde. As populações, como determinados atletas sob o domínio do arquétipo do herói, ultrapassam os limites, confiantes que sua saúde será prontamente restabelecida por um médico que se coloca no papel de mágico salvador.

$\mathrm{Na}$ atualidade, o esporte urge melhorar o rendimento dos atletas brasileiros e, efetivamente, gerar um modelo que estimule a saúde: social, física e psicológica. A mensuração das variações da cor da pele dos atletas nos jogos, como medida associada aos sintomas de estresse, poderá contribuir para o estabelecimento de parâmetros objetivos que sinalizem preventivamente problemas de saúde ao extrapolar os limites físicos e psicológicos.

Medansky, Handler e Riedge, citados por HOFFMANN, ZOGB, FLECK e MÜLLER (2005) afirmam que a origem embrionária comum da pele e do sistema nervoso é a base suficiente para assumir que um sistema pode ter sua contrapartida no outro. Os autores reafirmam a posição de Müller sobre o envolvimento da relação psique-pele em todos os aspectos subjetivos inerentes à personalidade: emoções, sentimentos, fantasias e agressividade, cuja intensidade refletir-se-ia na pele, como combustível das enfermidades cutâneas.

SANT' ANNA, GIOVANETTI, CASTANHO, BAZHUNI e LA SELVA (2003) relacionam os distúrbios dermatológicos a possíveis meios de expressão e compensação da rigidez no desempenho de papéis sociais, representados pela cristalização daquilo de C. G. Jung denomina persona.

A máscara que gruda na pele, ou seja, a pessoa que assume um único papel social em diferentes contextos, coloca-se no mundo de maneira inadequada, tendo em vista a multiplicidade e a flexibilidade que os arquétipos exigem no trato social. A pessoa sofre, mas a rigidez impede de mudar. Neste contexto, podem 
surgir manifestações somáticas na pele como forma de expressão de um organismo psicossomático.

Os autores citados reportam manifestações psicogenéticas na pele em virtude das origens embrionárias, comuns entre pele e sistema nervoso central, a superfície do sistema nervoso do embrião que virou para fora. Além disso, a pele, como superfície de contato, seria relacionada com o desenvolvimento psicossexual, tendo em vista a erotização das regiões que foram fontes de sensação e percepções da dor e do prazer. Na escola desenvolvimentista da psicologia analítica de E. Newmann, a noção do Eu é primordialmente corporal. O Eu deriva, essencialmente, das sensações originadas na superfície do corpo.

No campo dos esportes, é possível observar com freqüência, a comemoração de ações bem-sucedidas, além da constante referência a Deus. A estimulação cutânea: cumprimentos, toques, saltos, beijos, abraços são demonstrações de afetividade que se ligam às experiências passadas e trazem implícito o coping religioso e a estimulação da pele, como sinais que se inserem na memória corporal e estabelecem conexões neurais com os registros primários.

\subsection{Caracterização das crenças religiosas pelo Inventário Pratt de crenças religiosas no esporte}

O espetáculo esportivo realmente, nunca se inicia sem que se faça antes o sinal da cruz, uma prece ou oração, comportamentos que suscitam uma série de questionamentos sobre os objetivos, significados e implicações psicológicas das crenças religiosas dos atletas, como orientação básica da vida e reflexão sobre os valores éticos: respeito mútuo, dialogo, justiça, solidariedade (CONCEIÇÃO, 2004).

O esporte comporta a manifestação de diversas crenças religiosas, incluindose aquelas tidas como fetiche, crendices e superstições. Delimita uma área de interesses constantemente realçada pelas pessoas, porém, sem fazer uma distinção clara dos conceitos entre eles. Assim sendo, a mescla formada pela fusão entre as crenças religiosas e o esporte suscita uma série de fatores positivos e negativos (HIGGS, 1996; CONCEIÇÃO, 2004). 
As concepções estabelecidas na literatura científica por PRATT $(1907,1923)$, FREITAS (2002), CONCEIÇÃO (2004), evidenciam que as crenças religiosas caracteriterizar-se-iam em quatro dimensões, conforme a natureza particular dos conceitos, das idéias e representações a respeito de como a pessoa concebe, percebe, sente e usa a idéia de Deus. Assim, fundamentado nas pesquisas empíricas realizadas nos últimos cem anos com o "Questionário Pratt de crenças Religiosas". Quatro modalidades de crenças religiosas embasaram a construção do Inventário Pratt de crenças religiosas no esporte, apresentadas a seguir:

Crença primitiva - atitude religiosa que se manifestaria naturalmente no ser humano como credulidade espontânea em extensão ao universo cultural religioso em que o indivíduo se insere - a pessoa não questiona a crença, apenas reproduz os hábitos e costumes pela intermediação de figuras de autoridade (pessoas poderosas). Constitui-se como a crença primeira, cujas representações de Deus remeteriam às influências das tradições. Uma crença que se conservaria na vida adulta como que por inércia, porque a pessoa comporta-se de acordo com o molde primitivo.

Crença intelectual - é um tipo de atitude religiosa permeada pela desconfiança, que se guia mais pela razão, uma tentativa de se aproximar dos mistérios pela verificação e a constatação. Trata-se de uma modalidade de crença que surgiria após sucessivas crises nos moldes primitivos e incompatível com a realidade fenomenológica do indivíduo. $\mathrm{O}$ ceticismo que se instala por causa de frustrações que ocorrem no molde da crença primitiva. O conflito entre crença e a descrença marcado pela busca do objeto original da crença que foi perdido. Daí a necessidade de constatação, verificação, comprovação, evidências, conceitos intelectuais sofisticados e definições abstratas.

Apesar do conflito com a crença primitiva, a crença intelectual, também, admite a intermediação por figuras de autoridade. Segundo PRATT (1907, p. 39), o ser humano é incapaz de investigar mais do que uma porção infinitesimal de seu universo. Por isso, todas as pessoas, necessariamente e com razão, aceitam a maioria dos fatos, especialmente, os científicos e históricos, segundo a versão de especialistas (figuras de autoridade). 
A crença intelectual é identificada pela não-materialidade (ausência de representação por imagens), possuiria menor poder de mobilização da vontade que a crença primitiva. No entanto, sua natureza intangível dar-lhe-ia maior estabilidade, pois o intangível não pode ser destruído e os conceitos abstratos são mais difíceis de serem suplantados.

Crença emocional é a atitude religiosa que se apóia nos sentimentos concernentes a sensação de estar vivo, na percepção dos impulsos vitais, da energia e da força natureza, em conexão com experiências de fundo emocional pela identificação com o ilimitado, que é despertado por uma série de estímulos, entre os quais a atmosfera de luz e cor no ambiente das igrejas que se propicia pelos mosaicos bizantinos, como observado por AMUCHÁSTEGUI (2002).

Trata-se de um sentimento religioso que se traduziria pela sensação de fusão com o divino, uma conexão com Deus na forma de energia, que se constitui como uma modalidade de fé muito intensa, pois é experimentada como sensações corpóreas, capazes de mobilizar a vontade que poderiam ser caracterizadas, como experiências de natureza psicossomática, mobilizadas por meio de estímulos, entre os quais, imagens, cores e sons.

Para FREUD (1927) em O Futuro de uma llusão, o ego revela-se como algo bem demarcado e unitário no exterior, mas para dentro não possui uma delimitação precisa. Na verdade, exibe apenas uma aparência enganadora que serve de fachada ao id - impulsos e desejos. Neste contexto, a inflação do ego pelo sentimento oceânico aproxima-se do conceito de crença emocional, conforme a sensação de possuir um vínculo indissolúvel com o mundo e ser ilimitado, que no fundo reportaria ao narcisismo infantil. Este sentimento é sustentado na vida adulta pelo medo permanente do poder superior do destino, que se agrava no contexto do esporte, em face ao medo permanente de acidentar-se e produz ansiedade, inquietação e infelicidade.

Para FREUD (1927), o poder que resulta do sentimento oceânico, seria um aspecto puramente subjetivo, que não se trata de fé, pois uma pessoa que rejeita todas as religiões, pode ser considerada religiosa apenas com base no sentimento 
oceânico. Fonte de energia religiosa, cujos sistemas religiosos apoderaram-se, por conseqüência, o esporte na sociedade moderna é associado à religião desde a Grécia do Período Clássico.

Crença ético-moral é caracterizada mais pela atitude, a conscientização dos grandes valores da humanidade e não necessariamente o sentimento. O enfoque é a reflexão e o estabelecimento de moldes que orientem a ação: a coisa certa - aquilo que deve ser feito. Uma busca que traz por implícito a falta.

A ética compreendida como reflexão e filosofia da moral, embasadas nos grandes valores da humanidade: o respeito mútuo, o diálogo, a justiça e a solidariedade, que também, são expressos no ideal olímpico.

J. B. Pratt deixa transparecer o sentido da dimensão ético-moral no título de sua obra The Religious Consciousness (PRATT, 1927). Mostra um aspecto da crença religiosa voltado para uma atitude mais reflexiva, pela busca da consciência. Entretanto, deixa claro que ética e religião, por vezes, assumem posições distintas e por vezes quase inseparáveis (CONCEIÇÃO, 2004).

Os conceitos científicos envolvidos na diferenciação das crenças religiosas: primitiva, intelectual, emocional e ético-moral, que embasaram a construção do Inventário Pratt de crenças religiosas no esporte, trazem por implícito a representação de Deus para o atleta e a busca pela compreensão das crenças do atleta sobre o controle dos acontecimentos no esporte.

\subsection{Caracterização das expectativas do controle do esporte pela Escala de lócus de controle do esporte}

O lócus de controle é um conceito científico de grande difusão em nível mundial, que se originou da teoria da aprendizagem social no contexto dos conhecimentos formulados Julian B. Rotter no campo da psicologia social. Consiste a identificação da crença que a pessoa possui sobre a fonte de controle dos acontecimentos que sucedem na vida. 
TAMAYO (1989) cita o estudo Research with the locus of control construct realizado por Herbert M. Lefcourt e pondera que os estudos sobre lócus de controle oscilam entre a perspectiva motivacional e a fenomenológica existencial. Pois, a pessoa não apenas explica, mas também estrutura o destino de sua vida em virtude de suas crenças e expectativas.

HALL, LINDZEY e CAMPBELL (2000) observam que a teoria da personalidade proposta por Alfred Adler influenciou de forma decisiva a psicologia social nos EUA e o surgimento da teoria da aprendizagem social. Adler partiu da suposição que o ser humano é primariamente motivado por impulsos sociais inatos e pela tentativa de superar de sentimentos de inferioridade.

Os sentimentos de inferioridade não seriam unicamente ligados à sexualidade, mas se estenderiam a todas as facetas da vida social. A personalidade seria moldada por circunstâncias sociais, biológicas e psicológicas, idéias que exerceram influência sobre a psicologia social americana e contribuíram para alargar a visão excessivamente naturalista e pulsional que caracteriza a psicanálise.

Rotter procurou integrar os conhecimentos da tradição da psicologia social com as principais correntes psicológicas, entre as quais, a psicanálise e 0 behaviorismo, sob a hipótese de que o comportamento humano não poderia ser impulsionado, apenas pela busca de respostas seletivas, segundo os padrões de condicionamentos anteriores. Nem com base em experimentos com animais, considerados muito simples para abarcar a complexidade do ser humano.

Neste contexto, a teoria da aprendizagem social, procura abranger pelo conhecimento das expectativas sobre o controle dos acontecimentos futuros (contextualizados como reforços). A previsão do comportamento humano em ambientes relativamente complexos. Enuncia que a probabilidade de ocorrer uma determinada resposta, em uma dada situação, é função do valor subjetivo do reforço que se segue a resposta, ou seja, a percepção que a pessoa possui de que por meio de seu comportamento venha obter o reforço e do valor desse reforço para a pessoa naquela situação ROTTER, CHANCE e PHARES (1972), DELA COLETA (1982). 
O conceito de expectativa envolve a subjetividade e levou a dedução do lócus de controle por J. B. Rotter em 1966, publicou no jornal Psychological Monographs o artigo Generalized Expectancies for internal versus external control of reinforcement. Assim, a escala de lócus de controle surge como um instrumento que explica a percepção quanto às expectativas sobre o controle dos eventos. E, consciente do lócus de controle, a pessoa possa melhor administrar sua possibilidade de realização e engajar-se verdadeiramente nos projetos. Pois, o lócus de controle interno, associa-se ao sucesso nos mais diversos campos de atuação do ser humano.

Originalmente concebido como um constructo unidimensional: lócus de controle interno-externo. LEVENSON (1973) encontrou uma segunda dimensão ao lócus externo, subdividindo-o em lócus de controle externo pelo acaso (sorte-azar) e lócus de controle externo pessoas poderosas (autoridades e figuras de poder). Desenvolveu o instrumento denominado Multidimensional Locus of Control in Psychiatric Patients, traduzido para a língua portuguesa como Escala multidimensional do lócus de controle de Levenson (DELA COLETA, 1987).

A tendência na atualidade nas pesquisas sobre o lócus de controle é o desenvolvimento de escalas para avaliar áreas específicas. DELA COLETA (2004) sob a hipótese de que as tendências individuais trazem por implícito a percepção do controle sobre os acontecimentos que interferem na saúde dos indivíduos traduziu uma das formas equivalentes da Multidimensional Health locus of control (MHLC), denominada Escala de Lócus de Controle da Saúde, que se embasa na percepção da saúde desde totalmente dependente da pessoa (lócus de controle interno), até totalmente dependente de fatores externos: médicos e instituições da saúde (lócus de controle pessoas poderosas), ou da saúde intermediada pela sorteazar (lócus de controle pelo acaso).

CONCEIÇÃO $(2004,2006)$ em consonância com as tendências de segmentação em áreas específicas de aplicação das pesquisas sobre o lócus de controle constatou a necessidade de desenvolver um instrumento que avaliasse as expectativas dos atletas sobre os acontecimentos na carreira esportiva. Adaptou e validou a Escala multidimensional de lócus de controle do esporte em 
dissertação de mestrado na Escola de Educação Física e Esporte da Universidade de São Paulo, sob orientação de A. C. Simões e a colaboração de juízes externos, entre os quais, Marília Ferreira Dela Coleta e Luiza Beth Alonso.

A Escala multidimensional de lócus de controle do esporte avalia as crenças do atleta sobre o controle dos eventos que sucedem na carreira esportiva. Fornece dados e subsídios para a intervenção no processo atribucional do atleta visando modificar seu comportamento em virtude de suas crenças e expectativas quanto ao lócus de controle dos eventos no esporte de alto rendimento.

SINGER e ORBACH (1999), em citação ao trabalho de Sustaining Motivation de SINGER, assinalam que o potencial de realização no esporte está relacionado, entre outros aspectos, ao lócus de controle e às estratégias de coping dos atletas.

\subsection{Reflexões sobre dimensões do custo-benefício da mensuração da cor da pele e o impacto das expectativas no esporte de rendimento}

Luiza Beth Alonso $^{12}$ citada por SIMÕES (1996) considera que o ritmo respiratório e a musculatura relacionam-se com o comportamento socioemocional dos atletas, já que são partes naturais desse processo. Acepções que se ajustam a hipótese da interação entre mente e corpo e embasam a tese das oscilações cromáticas do tecido epitelial como sintoma de estresse propiciado pelo coping das crenças religiosas impactadas pelo lócus de controle dos atletas.

A respiração está de alguma forma relacionada com alterações cromáticas do tecido epitelial da pele, exemplo disso, as cianoses, coloração azulada das mucosas e da pele, causada pelo aumento da pressão parcial do $\mathrm{CO}_{2}$ (dióxido de carbono) e a diminuição do $\mathrm{O}_{2}$ (oxigênio) na corrente sangüínea ${ }^{13}$.

As concepções sobre esporte proferidas pelo Prof. Dr. Antonio Carlos Simões nas orientações ao curso de Pós Graduação da Escola de Educação Física da

\footnotetext{
${ }^{12}$ L. B. ALONSO. Esporte e psicologia: um debate necessário. In: Simpósio-Esporte: Dimensões Sociológicas e Políticas, São Paulo, 1993 Anais, São Paulo, EEFE-USP, 1993.

${ }^{13}$ A Prof. Dra. Taís Tinucci observa que a coloração azulada da pele no caso de indivíduos que produzem uma insuficiência respiratória, deve-se ao aumento da concentração de $\mathrm{CO}_{2}$ em relação ao $\mathrm{O}_{2}$ Refere que acontece o mesmo fenômeno nos casos clássicos de crianças que nascem com cardiopatia congênita. A coloração azulada pele deve-se a alta concentração de $\mathrm{CO}_{2}$ e baixa pressão parcial relativa de $\mathrm{O}_{2}$ na corrente sangüínea (comunicação pessoal).
} 
Universidade de São Paulo envolvem o esporte em um conjunto de manifestações socioculturais, organizadas por diversas instituições. Os resultados obtidos no esporte de alto rendimento são projetados e sacralizados pela mídia com o objetivo de promover metas institucionais, grupais e pessoais, visto que são diretamente envolvidos na relação custo-benefício e com as lideranças que promovem o "esporte espetáculo". Refletir sobre as condições que caracterizam as condutas e as atitudes no esporte de alto rendimento não é tarefa simples, levam-nos a avaliar os fenômenos psicossociais, sociodinâmicos e institucionais que influenciam no comportamento (SIMÕES, 2003).

A figura do herói (semideus), gerado pela união de um deus ou deusa com um ser humano. Constitui um arquétipo poderoso no imaginário do esporte. Representa uma disposição psicológica de natureza arquetípica que pode tornar-se dominante no inconsciente. Pois, a jornada do herói é marcada pelo extrapolar dos limites durante o percurso ou no final de sua saga. Culmina na tragédia por causa dos excessos e a falta de limites que marcam a perda da razão, domínio pelas paixões e o descontrole sobre o próprio poder.

A imagem de glamour em torno dos atletas em competições internacionais, aliada às metas institucionais de empresas em programas de marketing, divulgadas pela mídia, reforça o estereótipo que distancia o atleta do ser humano e o aproximam do arquétipo do herói. Entretanto, a crueza da realidade dos bastidores revela as estruturas precárias do esporte. Uma das situações mais difíceis que ilustram a profundidade e implicações do estresse do esporte na sociedade moderna foi o caso protagonizado pela nadadora Renata Câmara Agondi ${ }^{14}$ e sua técnica Judith Russo.

Em meados de 1998, a famosa nadadora da cidade de Santos - tricampeã paulista de maratonas aquáticas buscava firmar a imagem de grande competidora em águas abertas do circuito internacional. Era patrocinada por uma empresa do ramo financeiro, que associou sua imagem à da instituição em planos de expansão das atividades no mercado internacional.

\footnotetext{
${ }^{14} \mathrm{O}$ caso de Renata Câmara Agondi foi citado nas aulas do curso de pós-graduação na disciplina Aptidão e Condição Física: Desenvolvimento e Fatores Intervenientes, ministrada pela Prof. $\mathrm{Dr}^{\mathrm{a}}$ Maria Augusta Peduti Dal Molin Kiss
} 
Renata seria patrocinada em três provas importantes do calendário internacional e o circuito completar-se-ia com uma disputa no braço de mar que liga a Inglaterra e a França. A Travessia do Canal da Mancha, uma prova de natação que possui um significado simbólico importante, a associação entre o charme e o requinte dos franceses, com o arrojo do capitalismo Inglês, em meio ao tráfego intenso dos navios que cruzam o mar em direção aos principais portos da Europa.

HARRISS (2003), jornalista americano correspondente de Paris, afirma que a Travessia do Canal da Mancha ocupa um lugar significativo no imaginário da América - O Novo Mundo. Cita à declaração de Thomas Hetzel, nadador dos Estados Unidos da América (EUA) que integra o Hall of fame da CHANNEL SWIMMING ASSOCIATION (2008), afirmou que, entre os competidores de maratonas aquáticas, só são considerados grandes, aqueles que realizam a prova do Canal Inglês. Mas chama atenção para o fato de que poucos franceses e ingleses tentaram fazer a travessia, provavelmente, porque pessoas "excêntricas" são socialmente pouco valorizadas na Inglaterra e na França, pois considerariam "La Mancha" pouco civilizado e preferem as competições nas águas tépidas do Mediterrâneo.

A França proibiu a organização de maratonas pelo lado francês do canal, assim, as competições são organizadas na Inglaterra pela CSA, pois um dos principais obstáculos na travessia é a hipotermia, causa de $80 \%$ do insucesso nas tentativas de realizar a prova.

A BURSON-MARSTELLER (2008) declarou que Renata realizou três provas na Itália e conquistou o primeiro lugar na prova da Travessia do Imperador, o terceiro na Travessia de Transimeno-Turin e quarto na Travessia Capri-Nápoles. Entretanto, todos esperavam ansiosamente aquele que seria o feito mais importante, a quebra do recorde brasileiro na travessia do Canal da Mancha.

No dia 23 de agosto de 1988, dez nadadores iniciaram à prova. Renata acompanhada pelo barco de apoio Hilda May, conduzido pelo piloto inglês Colin Cook e o tripulante Grahan Featherbee, o fiscal da CSS, Mark Lews e sua técnica Judth Russo, na prova da Travessia do Canal da Mancha.

Depois de dez horas, já perto da costa francesa, Renata dava sinais de hipotermia e exaustão. Entretanto, negou-se aceitar a bóia jogada pelo piloto. Nas águas geladas e imprevisíveis do canal, os lábios de Renata tornaram-se azuis, o 
corpo começou a tremer incontrolavelmente e, nestas condições, os nadadores apresentam confusão mental, incapazes de responder às perguntas mais simples sobre si próprios e a orientação tempo-espaço (HARRIS 1995).

Em busca dos objetivos do esporte, o técnico depara-se com dificuldades em prescrever cargas máximas de trabalho e estabelecer limites, pois ficam expostos às pressões e exigências de rendimento máximo.

Renata C. Agondi (25) morreu de exaustão em um acentuado quadro de hipotermia, seu corpo foi retirado das águas pelo fiscal da prova e levada de helicóptero a um hospital de Paris, mas não pôde ser reanimada. O piloto da embarcação avisou pelo rádio à polícia francesa que a nadadora estava com problemas, mas não aceitou a ajuda oferecida.

A BURSON-MARSTELLER (2008) publicou que a técnica Judith Russo foi chamada a depor na corte de Boulogne-sur-Mer e presa, sob a acusação de "não dar assistência à pessoa em perigo" (omissão de socorro), recolhida à Casa de Detenção de Loos. Posteriormente, foi libertada, mediante o pagamento de fiança pelo patrocinador que também providenciou o traslado do corpo da atleta para o Brasil.

DE CASTELLA (2008) publicou no jornal Thelegraph que o processo contra a técnica brasileira continua inconcluso na França e que o caso de Renata é o mais controverso de um histórico de seis mortes no canal, pois a nadadora teria morrido de exaustão, depois que sua técnica descartou a possibilidade de retirá-la da água. Por causa disso, atualmente, o piloto do barco de apoio e não mais o técnico tem a última palavra para interromper a prova.

DELA COLETA (2004) averiguou em seus estudos que o lócus de controle interno está relacionado com o melhor desempenho na natação. O relato dos acontecimentos que culminaram na morte da brasileira, evidencia uma problemática em torno de lócus do controle. Por revelar indícios de que Renata seria extremamente orientada pelo lócus interno e a técnica Judith pelo lócus externo. Inferência que ganha consistência em face dos rumores que Renata e Judith teriam firmado um pacto, comum, entre técnicos e atletas em provas desse tipo, ser retirado da água apenas em caso de desmaio. 
O caso da nadadora põe em perspectiva a possível relação entre sintomas de estresse, expectativas do lócus de controle e as crenças religiosas e a oscilação da cor da pele dos atletas em situações extremas. Neste caso, a oscilação da cor da pele no eixo $a^{*}$ (vermelho-azul), dado que a hipotermia e a cianose caracterizam-se pela aparência azulada das mucosas e da cor da pele.

\subsection{A percepção da cor da pele como sinal da natureza física da luz: dos conceitos de Isaac Newton a Albert Einstein}

A percepção da cor da pele envolve fenômenos físicos, fisiológicos, neurológicos e psicológicos, de certa forma garante o ineditismo deste estudo, em razão da fragmentação da ciência. Por isso, faz-se necessária a revisão da cor em conexão com o componente físico do fenômeno.

O celebrado artigo Phaenomena of colours publicado por I. Newton, em 1671, pela Royal Society of London, demonstra a relação entre luz e cor por meio daquilo que, na atualidade, denomina-se monocromação ${ }^{15}$. Por meio de um experimento realizado pela disposição de dois prismas colocados em série, Newton conseguiu pela incidência de um feixe de luz solar, a separação da luz em diferentes faixas espectrais. O efeito clássico da refração da luz em faixas espectrais (as cores da luz). E, com um segundo prisma, realizou a seleção de faixas específicas e obteve a monocromação da luz solar, que projetada sobre a superfície de objetos coloridos, possibilitou-lhe revelar os fenômenos envolvidos pela absorção e reflexão no contexto da teoria de síntese aditiva ${ }^{16}$ e subtrativa (MOLLON, 2003).

Os experimentos sobre a mecânica da luz evidenciam que a cor da pele é percebida, como colorida por intermédio da síntese subtrativa da luz, parcialmente absorvida e refletida pelos grupos cromóforos dos pigmentos contidos na pele e no

\footnotetext{
15 Monocromação é um termo que se refere ao ato de separar um feixe de luz policromático em seus componentes individuais, por feixes de radiação. Fenômeno que é possível de ser constatado por meio da experiência completa de I. Newton, conforme a disposição de dois prismas colocados em série.

${ }^{16}$ A síntese aditiva da luz apóia-se na teoria que a luz "branca" resulta da mistura das diferentes faixas espectrais das cores da luz, que foram revelas por I. Newton por meio de um prisma. Já, a síntese subtrativa tem por base a teoria que a cor preta dos objetos, resulta da mistura de diversos pigmentos, por meio da absorção, quase total da luz em um mecanismo de absorção e reflexão, que é evidenciado pela maior captação de energia solar pelas cores escuras e que revela a cor como fenômeno indissociável da luz.
} 
sangue (melanina e hemoglobina), que são detectadas pelas opsinas e rodopsinas. Os pigmentos encontrados nas células do aparelho perceptivo visual do ser humano.

BARLEIN (2002) descreveu o traçado da trajetória do conceito corpuscular da luz de Isaac Newton aos conceitos da dualidade entre matéria e energia da teoria quântica de Albert Einstein, assim com base em observações experimentais publicou, em 1917, o artigo Zur quantentheorie der strahlung, teorias heurísticas sobre a quântica da luz que lhe renderam o prêmio Nobel.

Einstein resolveu as questões que a Física clássica não podia responder, propondo que a luz seja como um tipo de radiação eletromagnética (quantum) composta por partículas elementares que teriam comportamento similar ao do elétron, tendo em vista a teoria de Heisenberg ${ }^{17}$ que experimentalmente demonstrou o comportamento dual dos elétrons, entre partícula e onda eletromagnética.

O termo fóton deriva do grego yos (phôs), luz. Fenômeno possível de ser verificado em processos naturais e em experimentos físico-químicos. Einstein demonstrou a existência do fóton no âmbito da teoria da relatividade. A concepção de que no espaço os fótons constituir-se-iam como partículas de energia $(E)$, sem massa e sem carga ( $\boldsymbol{E}=\boldsymbol{c}$. $\boldsymbol{p}$ ). A energia que se move na velocidade da luz (c) cuja intensidade estaria relacionada à magnitude do momentum $(\boldsymbol{p}=h / \lambda)$, que representa a relação entre a freqüência $(\boldsymbol{h})$ e o comprimento da onda $(\boldsymbol{\lambda})$. Termo que substitui a matéria na clássica equação $\left(E=m \cdot c^{2}\right)$. As ondas "wireless": satélites; telefone celular; rádio; televisão; infravermelho; o ultravioleta; os raios $X$ e gama, a luz e as cores constituem radiação de natureza quântica, cujas características variam de acordo com a freqüência e o comprimento da onda.

No espectro luminoso visível, as ondas de luz têm comprimento que variam entre 400 a $750 \mathrm{~nm}\left(1 \mathrm{~nm}=10^{-9} \mathrm{~m}\right)$, correspondendo à freqüência de 750 a $400 \mathrm{Thz}$. Energia com freqüência superior a das ondas de rádio, cujos comprimentos variam entre $1 \mathrm{~mm}$ e $100 \mathrm{~km}$ e a freqüência entre $300 \mathrm{GHz}$ e $3 \mathrm{khz}$.

\footnotetext{
17 Heisemberg demonstrou por meio de deduções teóricas e experimentos que o elétron apresenta um comportamento dual, oscila entre matéria e energia. Provou que os elétrons possuem massa, por meio de demonstrações experimentais. Mas, apresentam comportamento similar às das ondas eletromagnéticas e, que seria impossível determinar a posição do elétron em um ponto fixo no espaço. Teoria que gera uma série de especulações a exemplo do que acontece com a teoria de Einstein.
} 
A cor da pele resulta do mecanismo de absorção e reflexão da luz que se difunde pelo espaço, em conformidade suas propriedades quânticas e mecânicas. As ondas de luz (fótons) ao atingirem o olho, penetram a córnea, a íris e o cristalino. A imagem incide sobre a retina e é focada, de acordo com a ação mecânica de contração e distensão dos músculos ciliares; que permitem acomodar a imagem de objetos em movimento e diferentes distâncias, exatamente sobre as células fotossensíveis do sistema nervoso - os cones e os bastonetes, células envolvidas no processo de percepção estereoscópica da cor encontrados apenas nos primatas superiores, e que teriam se desenvolvido mais recentemente no processo evolutivo (THE COLUMBIA ELETRONIC ENCYCLOPEDIA, 2008).

O processo fisiológico da percepção da cor da pele pelo ser humano é tricromático ${ }^{18}$ BIRREN (1978), GEGENFURTNER e SHARPE (2002), confirmam às teorias de Le Blom de 1722, atestadas por Young, em 1807; e por Helmholtz em 1852. A visão humana é mediada por apenas três tipos de fotorreceptores na retina, células do sistema nervoso que são ativadas por fótons em apenas três faixas de freqüência do espectro eletromagnético, denominados cones de ondas curtas (C) sensíveis a ondas de comprimento médio $420 \mathrm{~nm}$ (violeta); cones de ondas médias (M) sensíveis a ondas de comprimento médio $530 \mathrm{~nm}$ (verde) e cones de ondas longas (L) sensíveis a ondas de comprimento médio $560 \mathrm{~nm}$ (vermelho), tendo em vista os dados ilustrados pela FIGURA 3.

\footnotetext{
${ }^{18} \mathrm{O}$ processo tricromático de percepção das cores tem por base a teoria que existe na retina do olho humano três tipos de fotorreceptores, que são sensíveis as três cores primárias da luz: vermelho, verde e azul, ou seja, ondas curtas, médias e longas.
} 


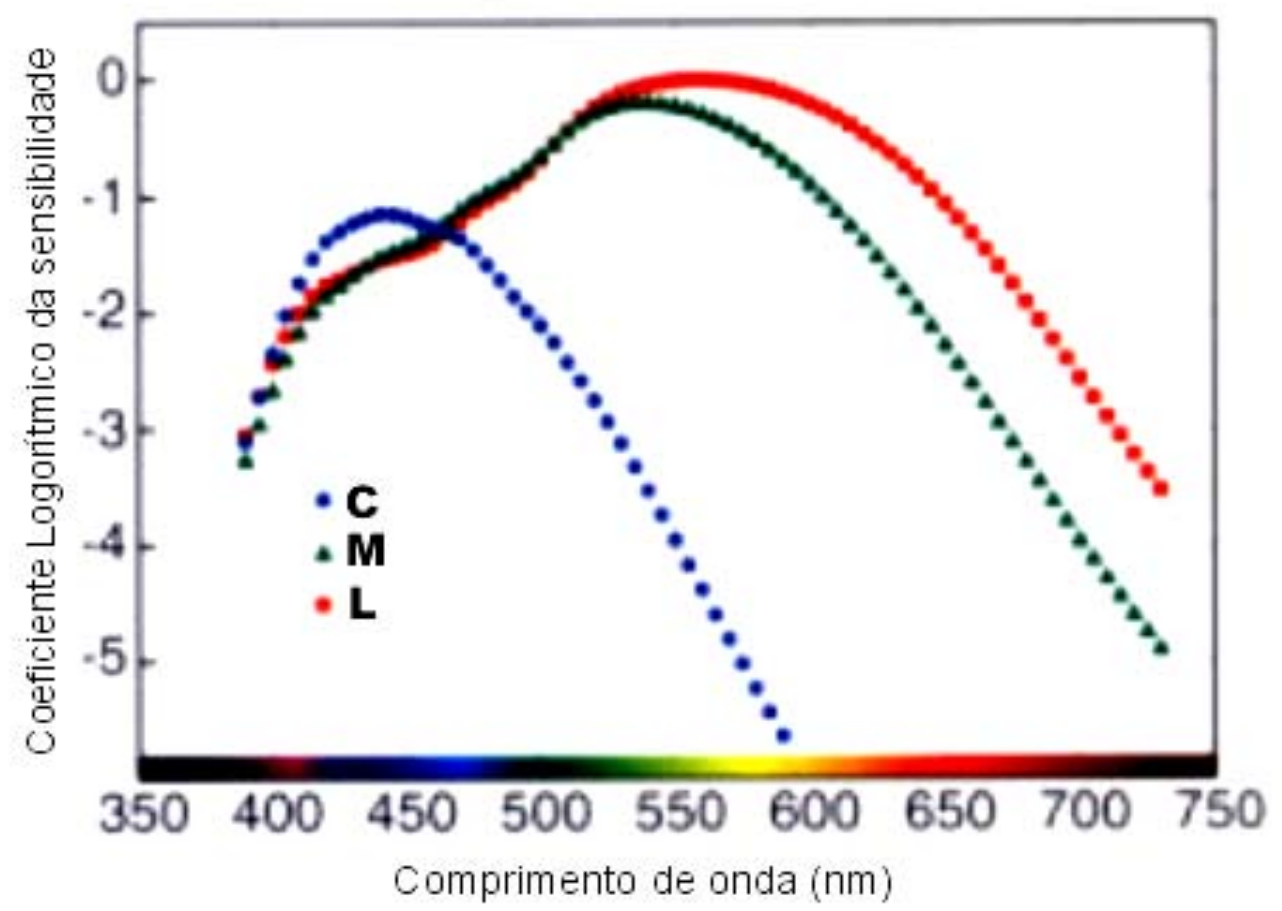

FIGURA 3 - Faixas de absorção espectral pelo olho humano nas células cones C, M, L (Fonte: GEGENFURTNER e SHARPE, 2002)

A FIGURA 3 revela certa superposição entre os espectros de absorção do vermelho e do verde, mas, GEGENFURTNER e SHARPE (2001) consideram ser possível diferenciar experimentalmente os fotorreceptores das ondas médias (M) e longas (L). A percepção de todas as cores seria possível apenas pela combinação da ativação dos fotorreceptores $C$ (vermelho), $M$ (verde) e L (azul-violeta).

A cor da tonalidade da pele caracterizada pelo "amarelão", por exemplo, seria percebida, conforme a ativação simultânea dos cones sensíveis aos estímulos eletromagnéticos nas faixas verde e vermelho. Tendo em vista a superposição dos fotorreceptores $\mathrm{M}$ e L, justificaria a limitada capacidade das pessoas ao perceber variações de saturação e a nuança da cor amarela composta pela superposição das luzes verde e vermelho, o fenômeno da síntese aditiva da luz e da síntese subtrativa dos pigmentos, ilustrados pelos dados da FIGURA 4. 


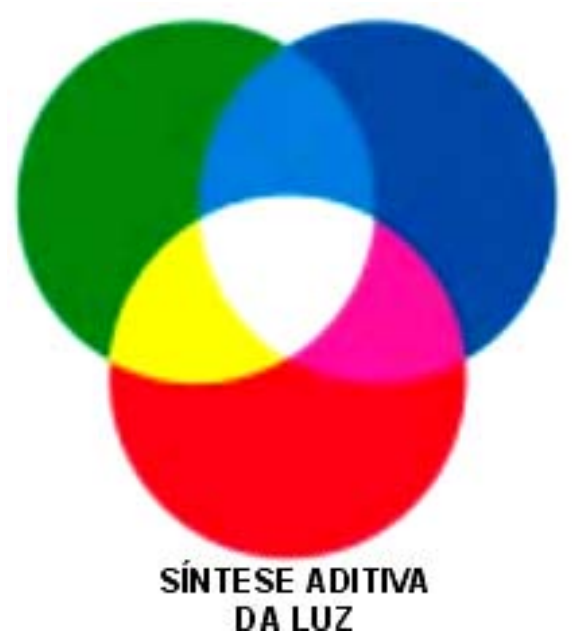

DA LUZ

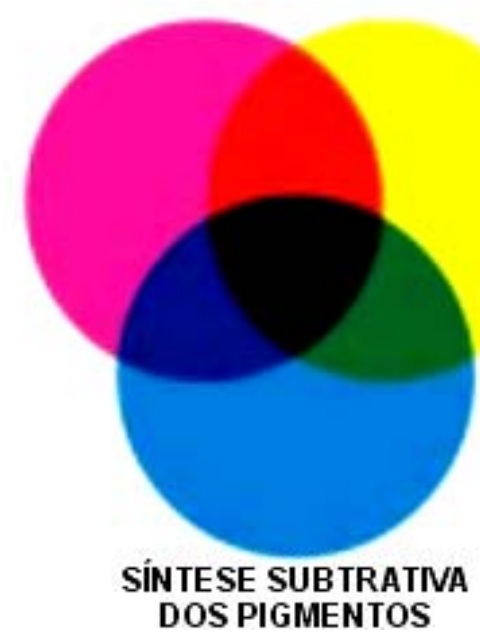

FIGURA 4 - Síntese aditiva e síntese subtrativa da luz

(Fonte: FARINA, 1975)

A FIGURA 4 revela o fenômeno envolvido pela síntese aditiva da luz, evidencia que as cores primárias da luz são: verde, azul e vermelho; e, que o branco é obtido pela síntese aditiva das cores primárias da luz. Já, o mecanismo demonstrado no lado direito da FIGURA 4, mostra os fenômenos envolvidos pela síntese subtrativa dos pigmentos, ou seja, as cores primárias dos pigmentos são o amarelo, o ciano e o magenta; percebidos, conforme os fenômenos luz-cor em síntese subtrativa, que explicam o fato da mistura das cores primárias dos pigmentos originarem o preto.

A percepção da cor amarela pelo olho humano dar-se-ia, secundariamente, conforme com a síntese aditiva da luz, a ativação simultânea dos fotorreceptores $M$ (verde) e L (vermelho). Por esta mesma lógica, a percepção do branco, resultaria da reflexão total da luz e ativação simultânea dos fotorreceptores $C, M$ e $L$ na retina.

Os fótons resultantes do processo de absorção e a reflexão da luz pelos pigmentos dos objetos atingem o olho humano e polarizam as opsinas, que são os pigmentos ativos dos cones $(C, M, e ~ L)$ e geram sinais eletroquímicos, que são transmitidos dos olhos, por meio de feixes de fibras nervosas, tendo em vista os impulsos de origem eletromagnética que seguem pelos nervos óticos: esquerdo e 
direito, cruzam-se no quiasma ótico e continuam pelos tratos em direção ao tálamo, hipotálamo e córtex visual (LEDOUX, 1998).

Os bastonetes são o quarto tipo de fotorreceptor que contêm o foto pigmento rodopsina e constituem as células prevalentes na retina do olho humano, mais de 95\% dos fotorreceptores (GEGENFURTNER e SHARPE, 2002). Entretanto, não contribuem para a percepção de cores. Pois, altamente sensíveis à luz, são as células responsáveis pela visão noturna, cujas características principais, baixa velocidade de resposta ao sinal luminoso, baixa resolução espacial e visão acromática, a diferenciação claro-escuro e brilho, uma das características da luz que mais fascina o ser humano.

$\mathrm{Na}$ atualidade, os neurocientistas e o biofisicistas, ainda, procuram esclarecer e aprofundar o conhecimento sobre a percepção sensorial da cor, tomando-se por base o estudo com os fotorreceptores (GEGENFURTNER e SHARPE, 2002).

\subsection{Oscilações cromáticas do tecido epitelial e "amarelão" como medida objetiva por meio da espectrofotometria}

SERUP, GREGOR e GARY (2006) observam que a cor da pele pode ser avaliada e comunicada por diversos meios, mas o rigor científico exige consistência da informação, e a cor sofre grande interferência de aspectos subjetivos, condições de iluminação, distância e linguagem para denominar as variações. Os autores afirmam que o melhor método para se descrever a cor da pele é o espectrofotométrico adaptado à leitura de refletância. No entanto, não possuí um padrão internacional de medição.

O valor ( $\mathrm{L}$ ) do inglês (light) no espaço tridimensional corresponde ao eixo (x), indica o nível claro (100) ou escuro (zero). O valor (a) corresponde ao eixo (y) e indica quando uma cor apresenta-se avermelhada (valores positivos) ou esverdeada (valores negativos) e o valor (b), que corresponde ao eixo ( $z$ ) e indica quando uma cor apresenta-se amarelada (valores positivos) ou azulada (valores negativos), tendo em vista o espaço representado pela FIGURA 5. 


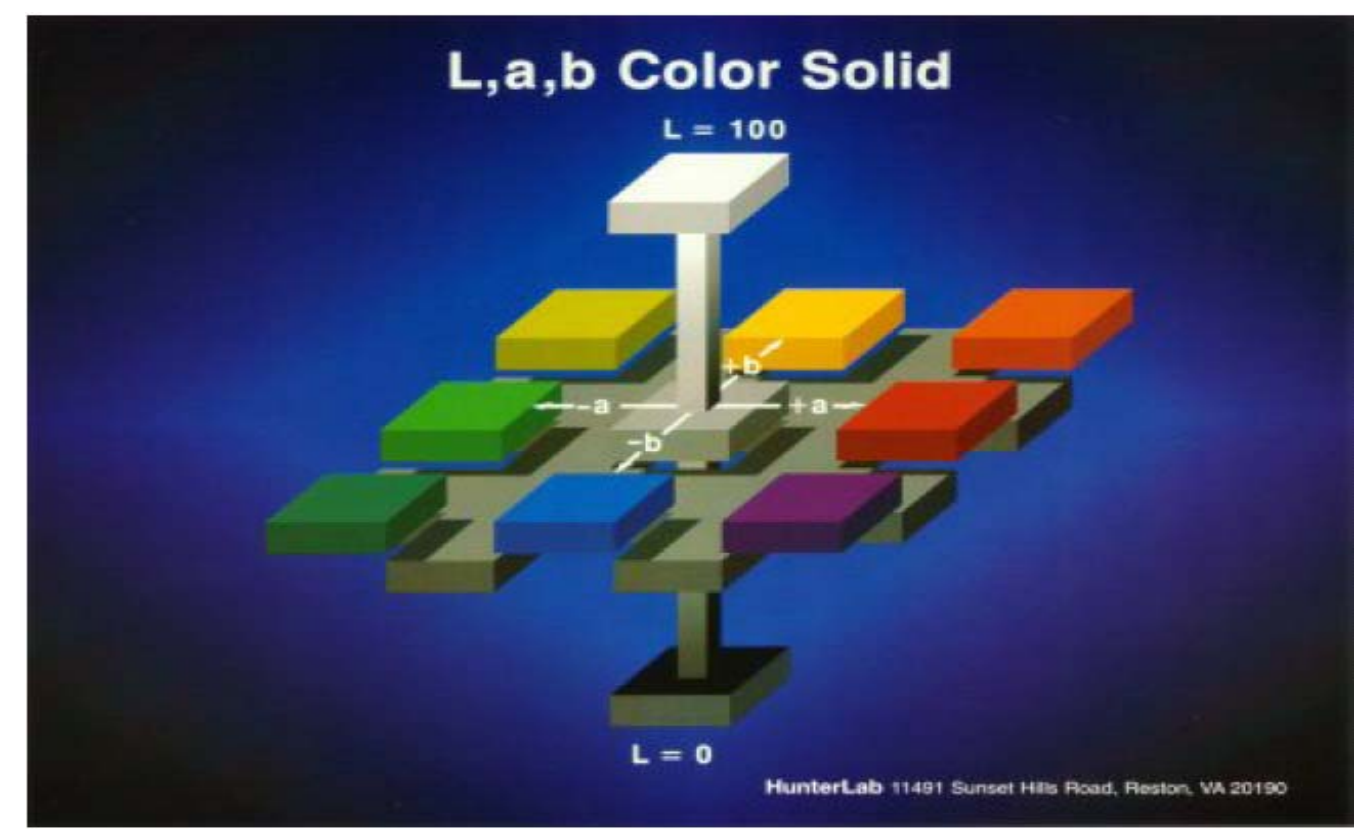

FIGURA 5 - Dimensões espaciais da cor definidas pelo Laboratorie du Commission Internationale de l'Eclairage CIE $\mathrm{L}^{*} \mathrm{a}^{*} \mathrm{~b}^{*}$ (Fonte: HUNTERLAB, 2008)

O espaço representado pela FIGURA 5 pode descrever as cores de qualquer objeto. Entretanto, o sistema de mensuração da cor pelos componentes L (claroescuro), a (vermelho-verde) e b (azul-amarelo) envolve ajuste de cálculo e disputas internacionais. A HUNTERLAB (2008), divulgou em notas de aplicação de seu sistema L, a, b, comparação com o sistema proposto pela Commission Internationale de I'Eclairage CIE L* $a^{*} b^{*} 1976$, que ambos os sistemas constituem espaços de cor válidos. Assim, apresentariam como única diferença a forma de cálculo. Explica-se que o sistema HUNTER L, a, b, mostra uma contração na região do amarelo e expansão na região envolvida pelo azul, já a escala $C I E L^{*} a^{*} b^{*}$ desenvolvida pelo Commission Internationale de l'Eclairage, apresentaria maior uniformidade e certa expansão na região do amarelo, dado que poderia causar certas distorções em aplicações específicas, mas em princípio, o fato seria mais favorável ao uso neste estudo. 
A mensuração da cor pelo sistema $L^{*} a^{*} b^{*}$ fundamenta-se na teoria da absorção-reflexão da luz e assume que os fotorreceptores do olho humano captam as cores como estímulos opostos, definíveis pelos pares dos opostos: claro-escuro, vermelho-verde e azul-amarelo conforme demonstrado na FIGURA 3.

Em princípio, as limitações da observação visual da cor da pele caracterizadas neste estudo como "amarelão" no esporte podem ser superadas pela avaliação instrumental, adotando-se o sistema internacional proposto pela $C I E \mathrm{~L}^{*} \mathrm{a}^{*}$ $\mathrm{b}^{*}$ proposto pela Commission Internationale de I'Eclairage

SERUP, GREGOR e GARY (2006) afirmam que o sistema internacional L* $a^{*}$ $\mathrm{b}^{*}$, estabelecido pela Commission Internationale de l'Eclairage (CIE), é recomendado para as medições da cor de pele, entretanto chamam atenção para os erros de medida, pela falta de uniformidade da pele: a variação da espessura da derme, epiderme e hipoderme ao longo do corpo e as dobras cutâneas. Afirmam que a oleosidade e a umidade afetam o brilho. Pêlos, vasos sangüíneos, pintas e cicatrizes podem ser determinantes no valor da medida.

UCHIDA (2006) descreve uma tecnologia de mensuração da cor da pele por "não contato", com o objetivo de minimizar os erros de mensuração por causa da variação da pressão exercida pelo aparelho no ato da medição, pois a grande sensibilidade da pele, da pressão e dos instrumentos de medição e as variações de cor afetam a precisão da análise espectrofotométrica da cor da pele. O sistema consiste no envolvimento de uma abertura maior que permite a realização das medições na região central. Daí, a denominação não contato.

UCHIDA (2006) relata que o Departamento de Cirurgia Plástica da Universidade de Tsukuba, no Japão, em pesquisas sobre a mensuração da cor da pele, acoplou ao Espectrofotômetro CS-1000, da empresa Minolta, um globo, com a finalidade de integrar a luz refletida pela pele e um cabo de fibra ótica que termina em uma abertura de cinco centímetros que pode ser posicionada sobre a pele.

O Departamento de Colorimetria da Escola Politécnica da Universidade de São Paulo possui um Espectrofotômetro CS-1000, entretanto, o aparelho não está adaptado para fazer medições da cor da pele, pois é utilizado, entre outras finalidades, na padronização de cores utilizadas em aparelhos de sinal de trânsito. 
A empresa japonesa MURACAMI COLOR RESEARCH LABORATORY (2006) desenvolveu um aparelho para medir a cor da pele, denominado Chromameter CMS-35SP, ilustrado pela FIGURA 6.

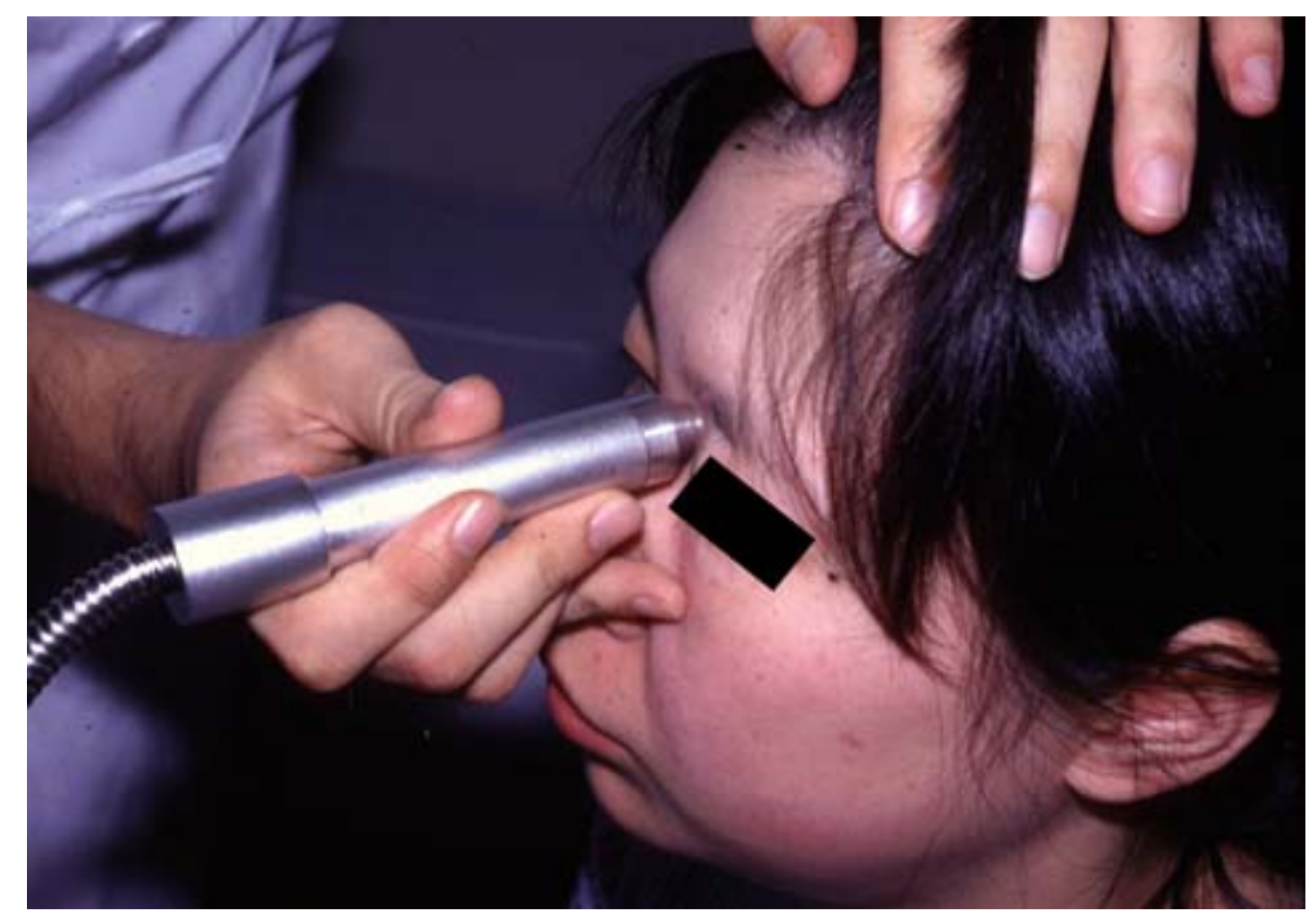

FIGURA 6 - Bocal de mensuração do Chromameter CMS-35SP (Fonte: MURACAMI COLOR RESEARCH LABORATORY, 2006)

A FIGURA 6 apresenta um equipamento desenvolvido no Japão que pode medir até a cor da pálpebra, medida que é utilizada para avaliar a cor dos cosméticos na pele, entre outras possíveis aplicações no campo da saúde. Entretanto, o problema com este equipamento é a possível contaminação das medidas pela luz do ambiente.

No Brasil, não existem estudos sobre a mensuração das oscilações espectrais da cor da pele. A maioria das pesquisas sobre a cor da pele, descrita pela literatura internacional, tem se limitado em medir as alterações de cor provocadas por agentes exógenos que causam estresse físico ou químico, entre as quais: Um estudo com base na idéia de que o estresse provoca uma série de oscilações na cor da dos peixes, realizado por meio de análises in vitro pela modulação de cortisol e 
variação da cor de amostras da epiderme da truta arco-íris VAN DER SALM, NOLAN e WENDELAAR BONGA (2002); Estudo do estresse fisiológico em tilápias por agente estressor ambiental, mediante a modulação da acidulação da água do aquário VAN DER SALM, SPANINGS, GRESNIGT, WENDELAAR BONGA e FLIK (2005); o estudo das oscilações espectrais da cor da pele seres humanos mediante a exposição ao ultravioleta STAMATAS e KOLLIAS (2004). Assim, existe um estudo sobre o eritema (vermelhidão da pele) em reações cutâneas a substâncias alergógenas, analisado por meio de fotografias (ROULLOT, AUTEGARDEN, DEVRIENDT e LEYNADIER, 2005).

GRAVLEE; DRESSLER; BERNARD (2005), ligados aos departamentos de antropologia da Universidade de Tallahassee e do Alabama, realizaram um estudo em uma comunidade da cidade de Guayma em Porto Rico, sobre aspectos étnicos e sócio-culturais envolvidos pelo estresse causado pela discriminação da cor da pele dos negros. Os pesquisadores mensuraram a pressão arterial e estimaram a quantidade de melanina por meio da mensuração espectro colorimétrica da pele com o Derma Spectrometer MIC620CTX, um equipamento de origem dinamarquesa fornecido pela empresa Cortex Technology. Mas, a hipótese da relação entre a cor da pele e hipertensão arterial, não se verificou, após inúmeras análises de regressão múltipla entre as variáveis: cor, idade, sexo, massa corporal, uso de medicamentos anti-hipertensivos e status sócio-econômico. Os pesquisadores concluíram que o status socioeconômico e não a cor da pele relacionou-se com a hipertensão arterial.

SERUP, GREGOR e GARY (2006) afirmam que o Chromameter CR-200 da Empresa Japonesa Minolta é um equipamento compacto que já foi utilizado em diversas pesquisas sobre câncer de pele, no âmbito da medicina nos Estados Unidos América, tendo como vantagem o preço mais competitivo em relação às pesquisas japonesas.

Mensurações da cor da pele, no braço, realizadas em uma clínica dermatológica nos Estados Unidos da América, com o aparelho Chromameter CR200, são ilustradas pela FIGURA 7. 


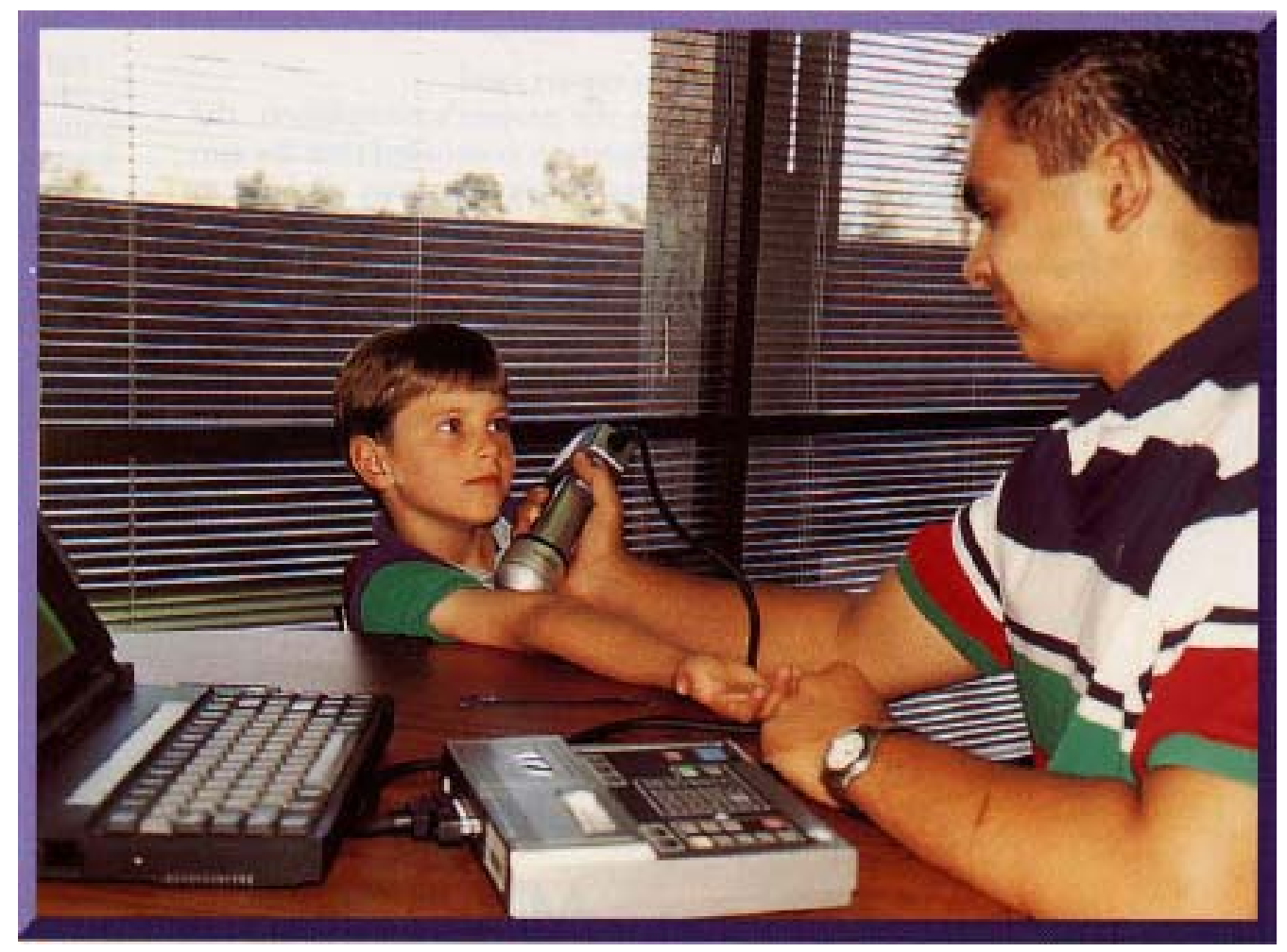

FIGURA 7 - Chromameter CR 200

(Fonte: KONICA MINOLTA SENSING AMÉRICAS, 2006)

SERUP, GREGOR e GARY (2006) afirmam que o aparelho Minolta Chomameter CR 200, ilustrado pela FIGURA 7, é um dos equipamentos mais modernos e precisos para medir a cor da pele, pois é compacto, construído, conforme a teoria triestímulos; analisa a cor por refletância por meio de fotocélulas de silicone altamente sensíveis à luz. Possui boa precisão e reprodutibilidade das medidas (erro 1\%). A iluminação é feita por uma lâmpada de xenônio de alto poder, que produz uma luz difusa, que é refletida com base no ângulo de observação hipotética de um observador em posição vertical e constante. A câmara de iluminação é cilíndrica e termina em uma abertura cônica, com quatro ou $11 \mathrm{~mm}$, cuja área de medição é estimada em $8 \mathrm{~mm}$.

A vista do que foi exposto até o momento em relação à esporte, cor da pele, estresse, crenças religiosas, lócus de controle e espectrofotometria, suscitam-se incertezas. 


\subsection{Será que...}

Ao ser questionado sobre sua postura em relação à ciência e à tecnologia, CAMPBELL (2007) cita um trecho de um texto hindu que diz respeito a um caminho que é perigoso como o fio de uma navalha. Assevera que, quando se enfrenta algo, que é novo e abre novos espaços, existe o perigo do entusiasmo. Por isso, a negligência de certos detalhes técnicos, como fez Ícaro. Assim, quando os rumos do desejo, do entusiasmo e da emoção são seguidos, é preciso conservar a mente sob controle para não se arrastar compulsivamente para o desastre. Observa que por algum motivo, as pessoas fazem mais referência a Ícaro do que a Dédalo, o arquiteto genial que escolheu voar moderadamente e, por isso, obteve sucesso.

O autor cita que os mitos oferecem um canal de comunicação com o mistério, o monstro (cabeça de animal e corpo de homem) no labirinto, linguagem metafórica que enfatizam o humano e, ao mesmo tempo, é uma celebração em direção à glória e ao esplendor da vida. A respeito do vazio espiritual, o tédio, a alienação e a impotência que as pessoas sentem em relação à sociedade moderna. Refere-se à obra The wast land (A terra devastada) de ELIOT e chama atenção para a estagnação sociológica de vidas inautênticas e o viver imposto pelo outro, o viver que não corresponde às reais necessidades espirituais, à criatividade, às potencialidades e, até mesmo, à coragem física tolhidas até que resultem em uma guerra desumana.

A tese deste trabalho consiste a hipótese que as oscilações da cor da pele dos atletas nos jogos e treinamentos podem ser caracterizadas pelo método espectrofotométrico associado ao estresse inerente ao esporte de competição, tomando-se por base os sintomas. A suposição de que a cromaticidade do tecido epitelial sofreria as oscilações de cor, caracterizadas como "amarelão", em razão da ativação do organismo por descargas hormonais no eixo hipotálamo supra-renal, mediadas por diferentes percepções do ambiente, a constrição do fluxo sangüíneo, conforme o coping propiciado pelas crenças religiosas dos atletas: primitiva, intelectual, emocional e ético-moral; impactados pelas expectativas do lócus de controle: interno, externo sorte-azar e pessoas poderosas. 
A revisão de literatura procurou ressaltar a multiplicidade dos fatores físicos, biológicos, fisiológicos, psicológicos e colorimétricos envolvidos na relação das variações da cor da pele, estresse, crenças religiosas e lócus de controle no esporte.

A complexidade dos fatores envolvidos pela cromaticidade do tecido epitelial está em conexão com os sintomas de estresse, o uso das crenças religiosas no esporte e as expectativas do lócus de controle. Diante do vazio espiritual da sociedade moderna, o estresse é o exceder dos limites, motivado por uma busca irracional que é impulsionada pela negação da condição humana.

Trata-se de um referencial metafórico, que pode oferecer conteúdos simbólicos à psicologia do esporte. Em verdade, é a oportunidade de melhorar o rendimento e a condição de treinamento dos atletas, em possíveis relações entre estresse, cor da pele, crenças religiosas e lócus de controle. Mas que, por outro lado, defrontamo-nos com múltiplos questionamentos:

- Será que as diferentes percepções dos atletas quanto ao lócus de controle e o coping propiciado pelas crenças religiosas alinham-se com o meio social ambiental e interferem nos sintomas de estresse?

- Será que as oscilações cromáticas da pele dos atletas na fase preparatória das competições esportivas evidenciadas pelo "amarelão" poderiam ser mensuradas por meio do método espectrofotométrico?

- Será que as oscilações da cor da pele dos atletas na fase preparatória para as competições (amarelão) estariam imbricadas com os sintomas de estresse e lócus de controle?

- Será que esses questionamentos podem ser investigados, mensurados e caracterizados como atributos disposicionais vinculados aos comportamentos dos atletas do Handebol, Ginástica Artística e Voleibol.

- Será que...

Estas indagações nos conduzem à formulação de algumas hipóteses sobre as relações factuais das variáveis envolvidas pelo estudo, a saber: 


\section{HIPÓTESE CENTRAL}

- O ambiente do esporte constitui-se, como um modelo de manifestações neuropsicológicas, bioinstintivas, psicofisiológicas, psicossociais e intrapessoais que se estruturam e desenvolvem-se, sinalizados pelas oscilações da cor da pele evidenciadas pelo "amarelão" como resposta dada pelo organismo humano ao se delinear entre os atletas e as formas de comportamentos alinhadas com o estresse, o coping propiciado pelas crenças religiosas (primitiva, intelectual, emocional e ético-moral) e o lócus de controle (interno e externo: sorte-azar, pessoas poderosas).

\subsection{Hipótese complementar}

- Os comportamentos e desempenhos evidenciados pelos atletas da Ginástica Artística, Handebol e Voleibol no transcorrer das fases preparatórias dos treinos que visam aos eventos competitivos. Revelam-se em respostas orgânicas desencadeadas pela ativação dos estados de estresse psicofisiológico mediados pelas crenças religiosas: primitiva, intelectual, emocional e ético-moral, associadas às expectativas do lócus de controle interno e externo: sorte-azar, pessoas poderosas.

\subsection{Hipótese alternativa de pesquisa}

- As oscilações cromáticas da cor $\left(L^{*}, a^{*}, b^{*}\right)$ do tecido epitelial no braço e no rosto dos atletas da Ginástica Artística, Handebol e Voleibol podem ser mensuradas por intermédio do método espectrofotométrico e têm relações estatísticas significativas com os sintomas de estresse, propiciados pelo coping dos diferentes tipos de crenças religiosas alinhadas ao lócus de controle dos atletas de alto desempenho. 


\section{DELIMITAÇÃO DO ESTUDO}

O presente estudo delimitou-se aos relatos de 32 atletas integrantes das equipes de Ginástica Artística, Handebol e Voleibol, maiores de 18 anos que atuavam no esporte de alto rendimento em um clube social e esportivo, tradicional da cidade de São Paulo, às mensurações espectrofotométricas $L^{*} a^{*} b^{*}$ pré e póstreinos, aos dados coletados, empregando-se o Inventário Pratt de crenças religiosas no esporte (IPCRE); a Escala multidimensional do lócus de controle do esporte (EMLCE) e a Lista de sintomas de estresse (LSS-VAS). Visa à obtenção de dados científicos que favoreçam a compreensão das oscilações da cor da pele dos atletas evidenciadas pelo "amarelão", sintomas de estresse e o coping propiciado pelas crenças religiosas impactadas pelas expectativas de lócus de controle dos atletas.

A pesquisa foi submetida à avaliação do Comitê de Ética da Escola de Educação Física e Esporte da Universidade de São Paulo, sob o título COMPLEXO ÍCARO: UM ESTUDO SOBRE LÓCUS DE CONTROLE, CRENÇAS RELIGIOSAS E A COR DA PELE DE ATLETAS DE ALTO NÍVEL. E foi aprovado (ANEXO I) em reunião ordinária do Comitê de Ética no dia 27/04/2007, estando em conformidade com a Portaria n 196/96 do Conselho Nacional de Saúde.

No transcorrer do estudo e o aprofundamento da pesquisa, optou-se por alterar o título do trabalho para "AMARELÃO" NO ESPORTE: DAS OSCILAÇÕES DA COR DA PELE AO COPING DO ESTRESSE POR CRENÇAS RELIGIOSAS E O LÓCUS DE CONTROLE DE ATLETAS DE HANDEBOL, GINÁSTICA ARTÍSTICA E VOLEIBOL. Considerando-se que esse título expressa melhor tema e delimita o a pesquisa melhor do que as sutilezas envolvidas pelos aspectos simbólicos dos extraordinários mitos que unem as sagas de Ícaro e Dédalo. 


\section{CASUÍSTICA}

O presente estudo apoiou-se no método de pesquisa de campo, descritivo e exploratório de aspectos quantitativos e qualitativos. Teve por objetivo analisar as possíveis relações entre as oscilações da cor da pele, sintomas de estresse e o coping propiciado pelas crenças religiosas e o lócus de controle dos atletas da Ginástica Artística, Handebol e Voleibol.

O delineamento da pesquisa e o critério de inclusão das equipes deram-se conforme as condições que se submetem a pesquisa de campo em face da escassez de recursos financeiros para realizá-la, das disposições dos técnicos e dos atletas em colaborar e das disponibilidades dos equipamentos para realizar as medições.

\subsection{Sujeitos}

Fizeram parte do estudo, oito atletas da Ginástica Artística, 12 do Handebol e 12 do Voleibol, totalizando $\mathrm{N}=32$ atletas de um clube social e esportivo tradicional na cidade de São Paulo. Assim, 29 atletas eram do sexo masculino e um do feminino, com idade cronológica entre 18 e 38 anos, sendo 12 atletas ingressantes no esporte de alto rendimento (Voleibol) e 18 com experiência em jogos e competições em nível nacional e internacional (Handebol e Ginástica Artística).

\subsection{Procedimentos da pesquisa}

Inicialmente, o pesquisador estabeleceu contatos telefônicos e por e-mail com os responsáveis pelas equipes, a fim de esclarecer os objetivos do estudo e obter consentimento e colaboração para que dessem seus treinamentos, conforme as necessidades dos grupos para atingir os objetivos da pesquisa.

Nos dias agendados, os atletas foram esclarecidos sobre os objetivos da pesquisa, sendo solicitado o consentimento e lhes assegurado o direito de desistirem da pesquisa a qualquer momento sem necessidade de explicações. 
O Espectrocolorímetro Minolta CR410 foi operado por um especialista em colorimetria, treinado pelo pesquisador para medir a cor da pele, foi calibrado em temperatura ambiente, com os padrões de branco e preto do fornecedor, para atenuar os problemas das oscilações da cor da pele, por causa da interferência da pressão do aparelho sobre a superfície da pele, pêlos, manchas e suor.

O tempo de preenchimento do Inventário Pratt de crenças religiosas no esporte e da Escala multidimensional de lócus de controle no esporte, demorou de 30 a 40 minutos e funcionou como período de condicionamento e estabilização das condições psicofisiológicas dos atletas, nas medições antes dos treinos. Os valores $L^{*} a^{*} b^{*}$ pré e pós-treinos, resultaram da média de três medições consecutivas no mesmo local: braço direito e rosto (lado direito da face). Os valores discrepantes foram descartados no ato da medição. As medições pós-treino foram realizadas imediatamente depois dos treinos e depois aplicou-se a lista de sintomas de estresse.

\subsection{Coleta de dados}

Os dados das crenças religiosas, lócus de controle e sintomas de estresse foram coletados pelo próprio pesquisador nas dependências do clube pesquisado: ginásio, quadra e pista de atletismo. Os instrumentos foram aplicados coletivamente nos grupos, variando entre seis e 12 atletas, de acordo com as disponibilidades em campo sob a perspectiva de proporcionar condições apropriadas à pesquisa.

Após o preenchimento da escala multidimensional do lócus de controle do esporte, os atletas responderam ao Inventário Pratt de Crenças Religiosas no Esporte sem interferência do pesquisador ou de terceiros. As dúvidas que surgiram foram sanadas individualmente.

No geral, os atletas mostraram-se prestativos e atenciosos, sem dificuldade para completar os instrumentos aplicados antes das medições pré-treinos. A lista de sintomas de estresse e os dados técnicos dos atletas foram aplicados depois do treino. Os atletas do Voleibol (projeto piloto), cujos dados integram o trabalho final, tiveram dificuldades para preencher a escala sobre a intensidade de sintomas de estresse, que foi reformulada. 
As mensurações da cor da pele foram realizadas por um engenheiro da $T \& M$ Instruments, que representa a Konica Minolta Sensing of Américas. A cor da pele no pré e pós-treinos foi medida por meio da média de três disparos consecutivos, abertura padrão de oito milímetros, bocal com protetor de umidade, posicionado na pele sem pressionar nem permitir a entrada de luz na câmera, medições realizadas no rosto (lado direito) e na parte medial interna do braço direito, em região isenta de pêlo, pinta e macha.

O procedimento foi adotado para evitar erros de medições, contaminação pela luz do ambiente ou alterações provocadas pela pressão do aparelho na pele do atleta. Quando os atletas tinham tatuagens, cicatrizes ou marcas na pele, que pudessem alterar os valores cromáticos da cor da pele, os procedimentos eram realizados no lado esquerdo, ver FIGURA 12.

\subsection{Análise dos dados}

Os dados obtidos das mensurações das oscilações da cor da pele dos atletas do Handebol, Voleibol e Ginástica Artística, nas dimensões de unidade de cor definidas no espaço espectral criado pelo Commission Internationale de l'Eclairage: CIE L* $a^{*} b^{*}$ (FIGURA 5). E os respectivos deltas: DL* (claro-escuro), Da* (vermelhoverde) e $\mathrm{Db}^{*}$ (azul - amarelo), obtidos pelo calculo das diferenças da média de três disparos de luz nas mensurações pós-treinos, subtraídas das mensurações antes dos treinos. Foram processados pelo programa de software desenvolvido pela Minolta para o Espectrocolorímetro CR 410. Posteriormente digitalizados em um computador com sistema operacional Microsoft Windows XP e analisados pelo programa SPSS versão 10.0, SPSS INC, 1989 - 1999 (USA) para procedimentos de estatística descritiva, estabelecimento de medidas de posição, dispersão, desviopadrão, valores mínimos, máximos e as respectivas tabelas e gráficos. Em razão do tamanho reduzido da amostra, foram utilizados testes não-paramétricos. As relações entre as variáveis foram estudadas por meio do coeficiente de correlação de Spearman. 


\subsection{Instrumentos de pesquisa}

\subsubsection{Espectrocolorímetro Minolta Chromameter CR $\mathbf{4 1 0}$}

O Espectrocolorímetro Minolta Chromameter CR 410 é um aparelho portátil que mede a intensidade da corrente elétrica, que é produzida pelas diferentes faixas do espectro eletromagnético, emitido por uma fonte de luz xenônio que simula o espectro solar (padrão: iluminante D 65).

Os feixes de luz são parcialmente absorvidos pela pele, e a parte refletida é captada por meio de filtros coloridos R (vermelho), G (verde) e B (violeta-azul), que simulam a percepção da energia eletromagnética pelo olho humano, tendo em vista a teoria dos fotorreceptores de ondas curtas médias e longas C (short), M (middle) e L (large), posicionados, conforme os padrões estabelecidos pela CIE para um observador hipotético. As informações sobre a cor da pele são transmitidas a um microcomputador portátil, acoplado ao espectrocolorímetro, processadas por meio de um programa de software desenvolvido pela Minolta, que calcula os valores espectrais $L^{*} a^{*} b^{*}$.

\subsubsection{Inventário Pratt de Crenças Religiosas no Esporte (IPCRE)}

O Inventário Pratt de crenças religiosas no esporte, procura investigar a natureza das crenças religiosas dos atletas, que se definem em torno dos conceitos de crenças primitivas, intelectuais, emocionais e ético-morais. Foi estruturado com base nos estudos empíricos sobre crenças religiosas de PRATT $(1907,1923)$, pelo Inventário Pratt de Crenças Religiosas, que foi traduzido por FREITAS (2002), e adaptado ao esporte por CONCEIÇÃO (2004), sob a orientação do Prof. Dr. Antonio Carlos Simões, baseado no critério de adaptação ao meio esportivo e submissão à análise das questões ao crivo de juízes especialistas; Professora Dra. Marta Helena de Freitas, Professora Dra. Luiza Beth Nunes Alonso e Professor MS. Luis Fernando Baccheret.

Constitui-se de uma série de dez questões e subitens com linguagem simplificada para aplicação no esporte. Os itens do instrumento original que foram 
considerados confusos, agressivos e/ou ofensivos pelos juízes nas fases de validação foram eliminados. Reformulou-se o instrumento sob a forma de alternativas, acompanhadas de espaços formatados para complementação das informações, que surgem como síntese dos conhecimentos oriundos do campo da pesquisa sobre crenças religiosas nos últimos 100 anos.

\subsubsection{Escala multidimensional de lócus de controle no esporte (EMLCE)}

A Escala multidimensional de lócus de controle do esporte, procura investigar as expectativas do lócus de controle dos atletas, definidas em torno dos conceitos de lócus controle: interno (atletas que possuem expectativas do controle dos acontecimentos na carreira esportiva, as suas próprias atitudes); lócus de controle externo: sorte-azar (atletas que têm por expectativas do controle dos eventos na carreira esportiva, o acaso, o destino, a sorte ou azar; o lócus de controle externo: pessoas poderosas (atletas que têm por expectativas do controle dos eventos que sucedem na carreira esportiva, a influência do poder de figuras de autoridade.

CONCEIÇÃO (2004) desenvolveu a Escala multidimensional de lócus de controle do esporte sob orientação do Prof. Dr. Antonio Carlos Simões, adotou os mesmos procedimentos metodológicos utilizados por LEVENSON (1973), na construção da Multidimensional locus of control in psychiatric patients, instrumento traduzido no Brasil por DELA COLETA (1987), embasado nos conceitos teóricos da teoria da aprendizagem social, que estruturam a Escala Unidimensional de Lócus de Controle de J. B. Rotter, que foi traduzida no Brasil por DELA COLETA (1979).

O critério de validação do instrumento contou com a submissão da Escala multidimensional de lócus de controle do esporte ao crivo de análise de juízes especialistas: as Professoras Dra. Marília Ferreira Dela Colleta e Luiza Beth Nunes Alonso e o Professor MS. Luís Fernando Baccheret. 


\subsubsection{Lista de Sintomas de Stress (LSS-VAS)}

A Lista de Sintomas de Stress, foi criada pelo Prof. Dr. Esdras Guerreiro Vasconcellos, com base no inventário Stress-Cope VASCONCELLOS (1985), em estudo desenvolvido com a colaboração de pesquisadores de diversos países. Constitui-se de 59 itens redigidos em primeira pessoa, sobre sintomas de estresse psicofisiológico e social, por exemplo: "Sinto a respiração ofegante"; "Qualquer coisa me apavora"; "Tenho desânimo"; "Tenho dor nas costas"; entre outros sintomas de estresse.

O sistema de avaliação dos sintomas de estresse envolve a identificação da freqüência em uma escala do tipo likert de quatro pontos, graduada da seguinte forma zero (nunca); um (raramente); dois (freqüentemente); e três (sempre). Além da freqüência, o respondente também deve assinalar a intensidade do sintoma. Os escores dos índices indicativos da freqüência de estresse variam entre zero e 177 e a intensidade entre zero e 266,5 .

\subsubsection{Nível de satisfação com a performance}

COELHO (2002) em um estudo sobre os sinais vocais (análise da voz por meio da freqüência do som) e sinais psicofisiológicos (análise da freqüência cardíaca e dos níveis de cortisol), mediante a ativação pelo estresse (avaliado pela lista de sintomas de stress LSS-VAS), provocado pela causados pela pressão de não poder errar e as implicações envolvidas na tarefa de falar ao vivo no telejornalismo. Constatou que o nível de satisfação com a "performance" dos repórteres é uma variável que interfere no estresse e no desempenho, avaliado por meio de uma questão: "Qual o nível de satisfação que você atribuiria a sua performance?" seguida pelas alternativas: nenhuma satisfação, pouca satisfação, razoável satisfação, muita satisfação e extrema satisfação.

A questão formulada pela referida pesquisadora foi Incluída no âmbito deste estudo em uma lista de questões sobre as características sociotécnicas dos atletas: posição do atleta, experiência no esporte, participação e competições internacionais e o uso de medicamentos pelos atletas 
Desenvolveu-se primeiro um projeto piloto com o objetivo de esclarecer as hipóteses, testar previamente os instrumentos de pesquisa e a possibilidade de mensurar a cor da pele dos atletas com o Espectrocolorímetro Minolta Chromameter CR 410. O projeto piloto constituiu-se por uma amostra de12 atletas do Voleibol masculino, ingressantes nas equipes de alto desempenho de um clube esportivo e social da cidade de São Paulo.

A escala multidimensional do lócus de controle do esporte e o inventário Pratt de crenças Religiosas no Esporte não apresentaram problemas na aplicação. $O$ tempo médio de preenchimento desses instrumentos foi de 30 a 40 minutos período que, além da obtenção dos dados, foi utilizado como condicionamento das condições gerais dos atletas: físicas e psicológicas.

As informações sobre as variações da cor da pele pré e pós-treinos foram coletadas com o espectrocolorímetro Minolta Chromameter CR 410, operado por um engenheiro da empresa T \& M Instruments.

O estudo-piloto mostrou algumas restrições quanto ao número de participantes nas mensurações pós-treinos, pois devem ser realizadas, imediatamente, após o término das atividades. De acordo com os protocolos da pesquisa, envolvem uma média de três medições consecutivas no mesmo local, que resultaram em mais de 72 disparos de luz. Cada medição dura em média cinco segundos, mas não podem conter valores discrepantes em decorrência de oscilações da pressão exercida pelo operador do equipamento sobre a pele, contaminações pela luz do ambiente por causa do mau posicionamento do bocal, suor, manchas e pêlos, sobretudo, no rosto dos atletas.

O procedimento adotado no caso de cicatrizes, manchas ou tatuagens nas regiões de mensuração definidas pelo estudo: braço direito e lado direito do rosto foi a inversão das posições para o lado oposto.

Da Lista de Sintomas de Estresse (LSS-VAS), apenas os 23 primeiros itens foram aplicados no projeto-piloto. Assim, foi possível mensurar apenas a freqüência dos sintomas de estresse, pois os atletas do Voleibol tiveram dificuldades para 
compreender as instruções de preenchimento da intensidade dos sintomas que, no instrumento original, utilizado no estudo-piloto, deveria ser assinalado em espaço vazio, disponibilizado ao lado dos itens de freqüência.

Os atletas do handebol não compreenderam as instruções, que foram as mesmas utilizadas por COELHO (2002), em um estudo sobre o estresse psicofisiológico no telejornalismo que, nas instruções, consta uma figura que simula o aumento da intensidade dos sintomas por meio do aumento gradual do ângulo formado por duas retas que resultam em uma figura oblíqua, mas os atletas deveriam assinalar a intensidade em um espaço que foi disponibilizado ao lado dos itens de freqüência.

A figura disposta nas instruções de preenchimento do instrumento original utilizado no projeto piloto foi preenchida com matizes graduais de tons de cinza em escala claro-escuro. Foi minimizada e inserida em cada um dos espaços disponibilizados ao lado de cada um dos 59 itens da LSS-VAS, com comprimento médio de quatro e meio centímetros, resultou em intensidades com amplitude de variação entre zero e 265,5.

Os dados obtidos reforçaram a hipótese de que o meio social ambiental institucional do esporte de alto rendimento apresenta-se, como um modelo de manifestações psicossociais sinalizadas por respostas dadas pelo organismo dos atletas em consonância com suas características psicofisiológicas alinhadas com variações da cor da pele, sintomas de estresse e coping por crenças religiosas e lócus de controle.

O desenvolvimento do projeto-piloto foi de fundamental importância para testar a aplicabilidade dos instrumentos e as hipóteses. No sentido de verificar se as mesmas tendências seriam mantidas no estudo final e em face da escassez de recursos financeiros, das dificuldades em disponibilizar os equipamentos e coordenar as agendas de todos os envolvidos, optou-se por incorporar os dados colhidos no projeto piloto ao estudo final. 


\section{APRESENTAÇÃO DOS RESULTADOS}

Os dados foram coletados em um clube social e esportivo de São Paulo, o estudo envolveu atletas de três modalidades esportivas: Ginástica Artística (oito); Handebol (12) e Voleibol (12), totalizando $N=32$ atletas. O desafio que se impôs, consistiu no esclarecimento das hipóteses sobre as variações da cor da pele, sintomas de estresse, o coping por crenças religiosas e o lócus de controle no ambiente institucionalizado do esporte de alto rendimento, caracterizado pela busca de maximização do desempenho.

Os dados obtidos dos atletas do Handebol apresentaram as condições mais favoráveis de pesquisa, por isso foram previamente apresentados e analisados. A seguir, foram mostrados os dados obtidos com os atletas do Voleibol e, finalizando os dados dos atletas da Ginástica Artística que, em razão do número limitado de sujeitos, foram analisados apenas no conjunto dos dados da investigação das variações da cor da pele, sintomas de estresse e o coping por crenças religiosas e lócus de controle de atletas da Ginástica Artística, Handebol e Voleibol.

$\mathrm{Na}$ análise estatística, foram usados procedimentos de estatística descritiva e o estabelecimento de medidas de posição, dispersão, desvio-padrão, valores mínimos e máximos. Pelo tamanho reduzido da amostra, foram utilizados os testes não-paramétricos. As relações entre as variáveis foram estudadas por meio do coeficiente de correlação de Spearman, com nível de significância $5 \%(p<0,05)$.

\subsection{Discussão dos dados dos atletas do Handebol}

A amostra que integra o estudo dos atletas do Handebol, compôs-se de 12 jogadores pertencentes à Seleção Brasileira de Handebol, do sexo masculino, oriundos de diferentes classes sociais e estados da Federação Brasileira, com média de idade 26 anos (mínimo de 22 e máximo de 38 anos). Três atletas possuíam nível de escolaridade superior completo, seis incompletos e três com escolaridade de nível médio. Quatro atletas eram católicos, dois cristãos, um espírita, um evangélico, três apenas acreditavam em Deus. 


\subsubsection{Caracterização das condições da coleta de dados do Handebol}

A coleta dos dados realizou-se no transcorrer dos treinos dos jogos pelo Campeonato Paulista 2008 e preparativos às Olimpíadas de Pequim 2008. Três dos 12 atletas pesquisados participaram das Olimpíadas de Pequim, a coleta iniciou-se por volta das 11 horas em uma manhã que os atletas retornavam de um jogo pelo Campeonato Paulista 2008, realizado na noite anterior, em uma cidade do interior de São Paulo.

Em relatos informais da Comissão Técnica e de alguns atletas, foi um jogo muito intenso, pois, a equipe adversária precedera a disputa, da noite anterior à pesquisa, obteve o empate com a equipe que foi campeã pelo Campeonato Brasileiro 2007. Por isso, havia expectativas de vencer "em casa" os Campeões da Liga Nacional 2007. Não lograram êxito, mas o jogo foi bastante disputado, conforme declarações dos atletas e da Comissão Técnica. Os atletas viajaram de volta a São Paulo na mesma noite, estavam cansados. Um deles relatou que só foi dormir por volta das cinco horas da manhã e apresentou-se no clube às 11 horas, conforme rotina dos treinos e jogos pelo Campeonato Paulista 2008.

Frente à situação, o técnico decidiu alterar a proposta inicial de realizar um jogo-treino de Handebol entre os próprios atletas e comunicou que, naquele dia, realizariam um treino mais light. Propôs aos atletas, como aquecimento, uma corrida de 20 minutos com intensidade variável, de acordo com a disposição de cada atleta.

Após a corrida, realizariam um jogo-treino de futebol, ao contrário do Handebol. Modalidade, que é inserida no treino dos atletas do Handebol com o intuito de alterar as rotinas treinamentos e promover maior descontração entre os atletas. Por isso, a coleta de dados e as medições da cor da pele dos atletas do Handebol foram realizadas antes e depois do aquecimento por corrida moderada, de acordo com as disposições individuais de cada atleta, o que possibilitou condições de pesquisa mais controlada que no jogo de futebol e menor possibilidade de interferência por outras variáveis. Além disso, os atletas declararam que estavam muito cansados, alguns externavam pouca disposição para treinar. Desse modo, foi 
possível testar a hipótese que o estresse provocaria oscilações na cor da pele antes, neste caso, o "amarelão" do treino.

A coleta de dados com os atletas do Handebol foi feita na área coberta da pista de atletismo do clube social e esportivo onde os atletas treinam. Consoante o protocolo da pesquisa, primeiro foram coletados os dados sobre crenças religiosas $\mathrm{e}$ lócus de controle, antes da mensuração da cor da pele. A aplicação do Inventário Pratt de crenças religiosas no esporte e da Escala multidimensional de lócus de controle do esporte demorou, em média, 40 minutos para que fosse preenchido. Período que tem por função a estabilização e condicionamento do quadro geral dos atletas, antes da mensuração inicial.

Os dados sobre freqüência e intensidade dos sintomas de estresse por meio da Lista de sintomas de estresse (LSS-VAS) foram obtidos depois da mensuração da cor da pele. Finalizado o trabalho de coleta de dados, o jogo de futebol foi cancelado, e os atletas foram almoçar. Após a refeição, a equipe técnica e alguns atletas analisaram via internet, um jogo de Handebol classificatório para as Olimpíadas, por meio de imagens transmitidas da Alemanha.

\subsubsection{Resultados obtidos sobre a oscilação da cor da pele dos atletas do Handebol pré e pós-treinos pelo método espectrofotométrico}

Para esclarecer as hipóteses, os principais dados obtidos pela mensuração da cor da pele na parte interna do braço e no rosto dos atletas do Handebol, relativos aos valores $L^{*} a^{*} b^{*}$ e seus respectivos deltas ${ }^{19}$ pré e pós-treinos; valores mínimos, máximos, média e desvio-padrão destacados pela TABELA 1 são apresentados.

\footnotetext{
${ }^{19}$ Os deltas das diferenças das oscilações da cor da pele foram calculados subtraindo-se os valores obtidos nas medições pós-treino das medições pré-treino, calculados por meio do programa de processamento de dados espectrais que acompanha o equipamento Espectro Colorimetro Minolta CR 410.
} 
TABELA 1 - Valores mínimos, máximos, médias e desvio-padrão da variação

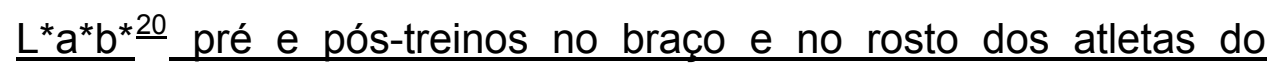
Handebol de alto desempenho

\begin{tabular}{lrrrrr}
\hline \hline & N & Mínimo & Máximo & Média & $\begin{array}{r}\text { Desvio } \\
\text { padrão }\end{array}$ \\
\hline L (braço) & 12 & 46,36 & 64,95 & 58,7775 & 6,3338 \\
L (rosto) & 12 & 47,31 & 63,89 & 56,0808 & 5,1615 \\
DL (braço) & 12 & $-2,35$ & 1,74 &,- 4417 & 1,2638 \\
DL (rosto) & 12 & $-4,02$ & 6,86 & 1,1033 & 2,8984 \\
a* (braço) & 12 & 7,01 & 11,53 & 9,2342 & 1,4644 \\
a* (rosto) & 12 & 10,35 & 17,20 & 13,9133 & 2,2620 \\
Da* (braço) & 12 &,- 91 & 1,47 &, 3767 &, 7343 \\
Da* (rosto) & 12 & $-7,55$ & 4,13 & $-1,1175$ & 2,7411 \\
b* (braço) & 12 & 16,12 & 20,96 & 18,7850 & 1,6129 \\
b* (rosto) & 12 & 15,47 & 21,19 & 17,9392 & 2,0090 \\
Db* (braço) & 12 &,- 93 &, 46 &,- 1883 &, 5160 \\
Db* (rosto) & 12 & $-4,19$ & 1,22 &,- 2006 & 1,4348 \\
casos válidos & 12 & & & & \\
\hline \hline
\end{tabular}

Fonte: Arquivo do pesquisador

\footnotetext{
${ }^{20}$ CIE L* $\mathrm{a}^{*} \mathrm{~b}^{*}$ - unidades de medida de cor proposto pelo Commission Internationale de E'clairege com base na teoria de absorção e reflexão da luz, ver FIGURA 5, p. 42: L* (claro-escuro); a* (vermelho-verde); b* (azulamarelo).

L* - o valor zero corresponde à absorção máxima da luz (preto) e valor 100 à reflexão máxima (branco) $\mathrm{a}^{*}$ - os valores negativos ( zero à -50) correspondem ao verde; e os valores positivos ( zero à 50) ao vermelho b* - os valores negativos ( zero à -50) correspondem ao azul e os valores positivos ( zero à 50) ao amarelo Os valores de delta: $\mathrm{DL}^{*}, \mathrm{Da}^{*}, \mathrm{Db}^{*}$ das diferenças das oscilações da cor da pele foram calculados subtraindo-se os valores obtidos nas medições pós-treino das medições pré-treino.
} 
A observação dos dados apresentados na TABELA 1 demonstra que houve variações entre valores positivos e negativos nas três dimensões da cor definidas no espaço CIE L*a*b*. Os valores negativos dos deltas: $\mathrm{DL}^{*}, \mathrm{Da}^{*}$ e $\mathrm{Db}^{*}$ indicam, respectivamente, que a pele ficou menos clara, menos vermelha e menos amarela, após o treino e corrida de intensidade variável, conforme as disposições físicas e psicológicas dos atletas durante 20 minutos.

\subsubsection{Resultados obtidos sobre freqüência e intensidade dos sintomas de estresse dos atletas do Handebol pela Lista de Sintomas de Stress (LSS-VAS)}

Os valores de freqüência foram obtidos pelo somatório da freqüência parcial dos 59 itens de sintomas de estresse da Lista de Sintomas de Stress LSS-VAS, que podem variar de zero a 177.

A divisão dos valores em quartis facilita a compreensão dos dados. Porém, conforme o Prof. Dr. Esdras Guerreiro Vasconcellos ${ }^{21}$, o estresse não se distribui eqüitativamente pela população, a quase ausência de estresse corresponde a $13 \%$ (primeiro quartil).

Assim, valores iguais ou inferiores a 23 , denotando baixa freqüência dos sintomas de estresse. O segundo quartil compreendeu valores de 24 a 74, indicando média freqüência de sintomas de estresse. $O$ terceiro quartil mostrou valores de 75 a 125 , alta freqüência dos sintomas de estresse e o quarto quartil, valores entre $126 \mathrm{e}$ 177, que denotam altíssima freqüência de sintomas de estresse, cujos dados são destacados pela TABELA 2.

\footnotetext{
${ }^{21}$ Comunicação pessoal
} 
TABELA 2 - Freqüência de sintomas de estresse de atletas do Handebol de alto desempenho por meio da Lista de Sintomas de Stress LSS-VAS

SINTOMAS DE ESTRESSE (LSS-VAS)

\begin{tabular}{|c|c|c|c|c|c|}
\hline & & & $\begin{array}{r}23 \text { itens } \\
\text { (FREQÜÊNCIA) }\end{array}$ & $\begin{array}{r}59 \text { itens } \\
\text { (FREQÜÊNCIA) }\end{array}$ & $\begin{array}{r}59 \text { itens } \\
\text { (INTENSIDADE) }\end{array}$ \\
\hline \multirow{13}{*}{$\begin{aligned} \text { HANDEBOL Seleção } \\
\text { Brasileira }\end{aligned}$} & 1 & & 20,00 & 38 & 53,60 \\
\hline & 2 & & 24,00 & 44 & 210,00 \\
\hline & 3 & & 22,00 & 59 & 97,20 \\
\hline & 4 & & 27,00 & 70 & 112,72 \\
\hline & 5 & & 14,00 & 32 & 40,70 \\
\hline & 6 & & 22,00 & 51 & 59,30 \\
\hline & 7 & & 28,00 & 53 & 93,60 \\
\hline & 8 & & 14,00 & 45 & 80,40 \\
\hline & 9 & & 25,00 & 54 & 57,70 \\
\hline & Total & $\mathrm{N}$ & 9 & 9 & 9 \\
\hline & & Média & 21,7778 & 49,56 & 89,4689 \\
\hline & & Mínimo & 14,00 & 32 & 40,70 \\
\hline & & Máximo & 28,00 & 70 & 210,00 \\
\hline \multirow{7}{*}{$\begin{array}{l}\text { Jogos Olímpicos } \\
\text { de Pequim } 2008\end{array}$} & 1 & & 35,00 & 84 & 86,70 \\
\hline & 2 & & 25,00 & 43 & 68,10 \\
\hline & 3 & & 18,00 & 42 & 35,00 \\
\hline & Total & $\mathrm{N}$ & 3 & 3 & 3 \\
\hline & & Mean & 26,0000 & 56,33 & 63,2667 \\
\hline & & Minimum & 18,00 & 42 & 35,00 \\
\hline & & Maximum & 35,00 & 84 & 86,70 \\
\hline \multirow[t]{4}{*}{ Total } & $\mathrm{N}$ & & 12 & 12 & 12 \\
\hline & Mean & & 22,8333 & 51,25 & 82,9183 \\
\hline & Minimum & & 14,00 & 32 & 35,00 \\
\hline & Maximum & & 35,00 & 84 & 210,00 \\
\hline
\end{tabular}

a. Fonte: arquivo do pesquisador

Os dados da TABELA 2 demonstram que seis dos 12 atletas do Handebol pesquisados $(50 \%)$ apresentam baixa freqüência dos sintomas de estresse (primeiro quartil) e seis (50\%) mostraram média freqüência de sintomas de estresse (segundo quartil). Dois dos três atletas convocados para as Olimpíadas de Pequim 2008 foram os que tiveram as maiores médias de freqüência dos sintomas de estresse. 


\subsubsection{Análise das associações entre freqüência e intensidade dos sintomas de estresse e a oscilação espectral da cor da pele no rosto e braço dos atletas do Handebol}

A análise pelo coeficiente de correlação de Spearman entre a freqüência dos sintomas de estresse e os deltas ${ }^{22}$ das diferenças de cor em medições no braço e no rosto por meio dos valores espectrais ${ }^{23} \mathrm{DL}^{*}$ (claro-escuro), Da* (vermelho-verde) e $\mathrm{Db}^{*}$ (azul-amarelo) ${ }^{24}$, mostrou os dados destacados pela TABELA 3.

TABELA 3 - Análise de correlação da freqüência e intensidade dos sintomas de estresse e a oscilação espectral da cor da pele no rosto e braço dos atletas do Handebol

TESTE DE CORRELAÇÃO DE SPEARMAN

\begin{tabular}{llrrrrrr}
\hline \hline & & $\begin{array}{r}\mathrm{DL} \\
\text { (braço) }\end{array}$ & $\begin{array}{r}\mathrm{Da}^{*} \\
\text { (braço) }\end{array}$ & $\begin{array}{r}\mathrm{Db}^{*} \\
\text { (braço) }\end{array}$ & $\begin{array}{r}\mathrm{DL} \\
\text { (rosto) }\end{array}$ & $\begin{array}{r}\mathrm{Da}^{*} \\
\text { (rosto) }\end{array}$ & $\begin{array}{r}\mathrm{Db}^{*} \\
\text { (rosto) }\end{array}$ \\
\hline LSS-VAS & Coefic. &, 081 &,- 123 &,- 601 &,- 583 &,- 004 &,- 032 \\
(freqüência parcial) & Sig. &, 803 &, 703 &, 039 &, 046 &, 991 &, 922 \\
& $\mathrm{~N}$ & 12 & 12 & 12 & 12 & 12 & 12 \\
\hline LSS-VAS & Coefic. &, 126 &, 217 &,- 671 &,- 720 &, 126 &,- 413 \\
(freqüência total) & Sig. &, 697 &, 499 &, $\mathbf{0 1 7}$ &, $\mathbf{0 0 8}$ &, 697 &, 183 \\
& $\mathrm{~N}$ & 12 & 12 & 12 & 12 & 12 & 12 \\
\hline LSS-VAS & Coefic. &,- 091 &,- 004 &,- 739 &,- 259 &,- 378 &,- 025 \\
(intensidade & Sig. &, 778 &, 991 & $\underline{, 006}$ &, 416 &, 225 &, 940 \\
parcial) & $\mathrm{N}$ & 12 & 12 & 12 & 12 & 12 & 12 \\
\hline LSS-VAS & Coefic. &,- 105 &, 252 &,- 853 &,- 350 &,- 238 &,- 112 \\
(intensidade total) & Sig. &, 746 &, 430 &, 000 &, 265 &, 457 &, 729 \\
& $\mathrm{~N}$ & 12 & 12 & 12 & 12 & 12 & 12 \\
\hline \hline
\end{tabular}

${ }^{22}$ CIE L* $\mathrm{a}^{*} \mathrm{~b}^{*}$ - unidades de medida de cor proposto pelo Commission Internationale de E'clairege com base na teoria de absorção e reflexão da luz, ver FIGURA 5, p. 42: L* (claro-escuro); a* (vermelho-verde); b* (azulamarelo). Os deltas das diferenças das oscilações da cor da pele foram calculados subtraindo-se os valores obtidos nas medições pós-treino das medições pré-treino.

${ }^{23}$ Correlacionou-se pelo teste de Spearman os valores de freqüência e intensidade de estresse com os deltas das diferenças das medições pós e pré-treino. 
Os dados apresentados na TABELA 3 mostram que houve correlação significativa da oscilação da cor da pele no eixo $\mathrm{DL}^{*}$ (claro-escuro) nas medições rosto e na freqüência dos sintomas de estresse LSS-VAS: parcial dos primeiros 21 itens $(p=\mathbf{0 , 0 4 6})$ e total dos 59 itens $(p=\underline{\mathbf{0}, 008})$. Não houve correlação significativa da oscilação da cor da pele no eixo $\mathrm{DL}^{*}$, nas medições rosto e intensidade parcial $(p=0,416)$ e total $(p=0,265)$. Os dados da TABELA 3 , também, mostram que houve correlação significativa da oscilação da cor da pele no eixo Db* (azul-amarelo) nas medições no braço e a freqüência de sintomas de estresse LSS-VAS: parcial $(p=0,039)$ e total $(p=\underline{0,017})$. Também houve correlação significativa da oscilação da cor da pele no eixo $\mathrm{Db}^{*}$ nas medições do braço com a intensidade parcial $(p=\underline{\mathbf{0 , 0 0 6}})$ e total $(\mathbf{p}=\underline{\mathbf{0}, 000})$ dos sintomas de estresse.

O tipo de associação da oscilação espectral da cor da pele $\mathrm{Db}^{*}$ nas medições do braço e das freqüências parcial e total de sintomas de estresse da LSS-VAS, é destacado pelos dados da FIGURA 8.

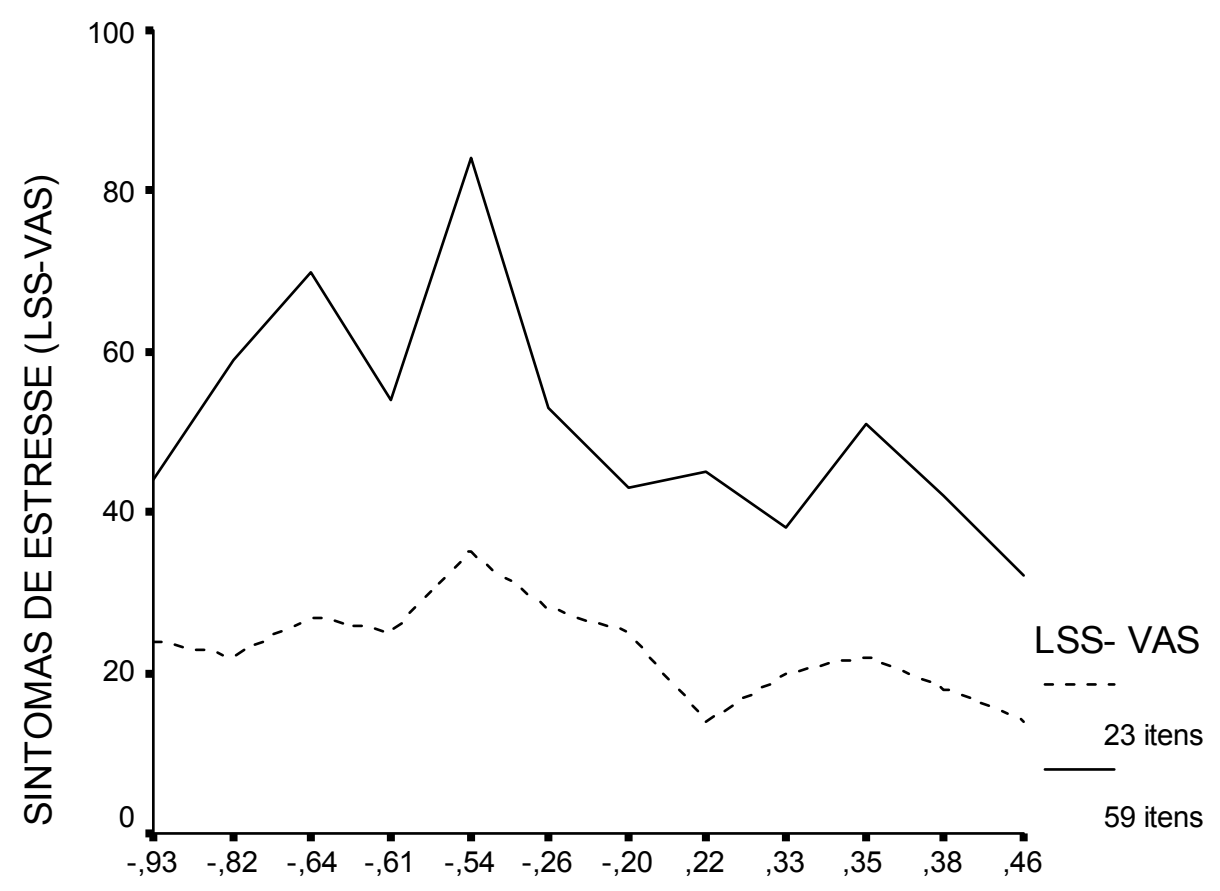

DIFERENÇAS ESPECTRAIS Db* (AZUL- AMARELO)

FIGURA 8 - Variação espectrofotométrica dos valores $\mathrm{Db}^{*}$ (azul-amarelo) no Handebol e a freqüência de sintomas de estresse (LSS-VAS) 
Os dados da FIGURA 8 mostram a tendência dos escores mais elevados de freqüência estresse LSS-VAS associarem-se aos menores valores de $\mathrm{Db}^{*}$. Isto significa que os atletas que revelaram maior freqüência de sintomas de estresse, apresentavam a cor da pele na parte interna do braço, significativamente, mais amarelada nas medições, antes do treino. Os dados são favoráveis à hipótese do amarelão.

\subsubsection{Análise das correlações mais fortes obtidas entre a oscilação espectral da cor da pele dos atletas do Handebol $\mathrm{Db}^{*}$ no braço e freqüência de sintomas de estresse LSS-VAS}

Com o objetivo de esclarecer as hipóteses de pesquisa, foram analisados 0 de tipo de associação entre a oscilação da cor da pele $\mathrm{Db}^{*}$ (azul-amarelo) nas medições no braço e a freqüência de sintomas de estresse pelos itens da LSS-VAS que apresentaram as correlações mais fortes $(p<0,02)$, consoante os dados destacados pela FIGURA 9.

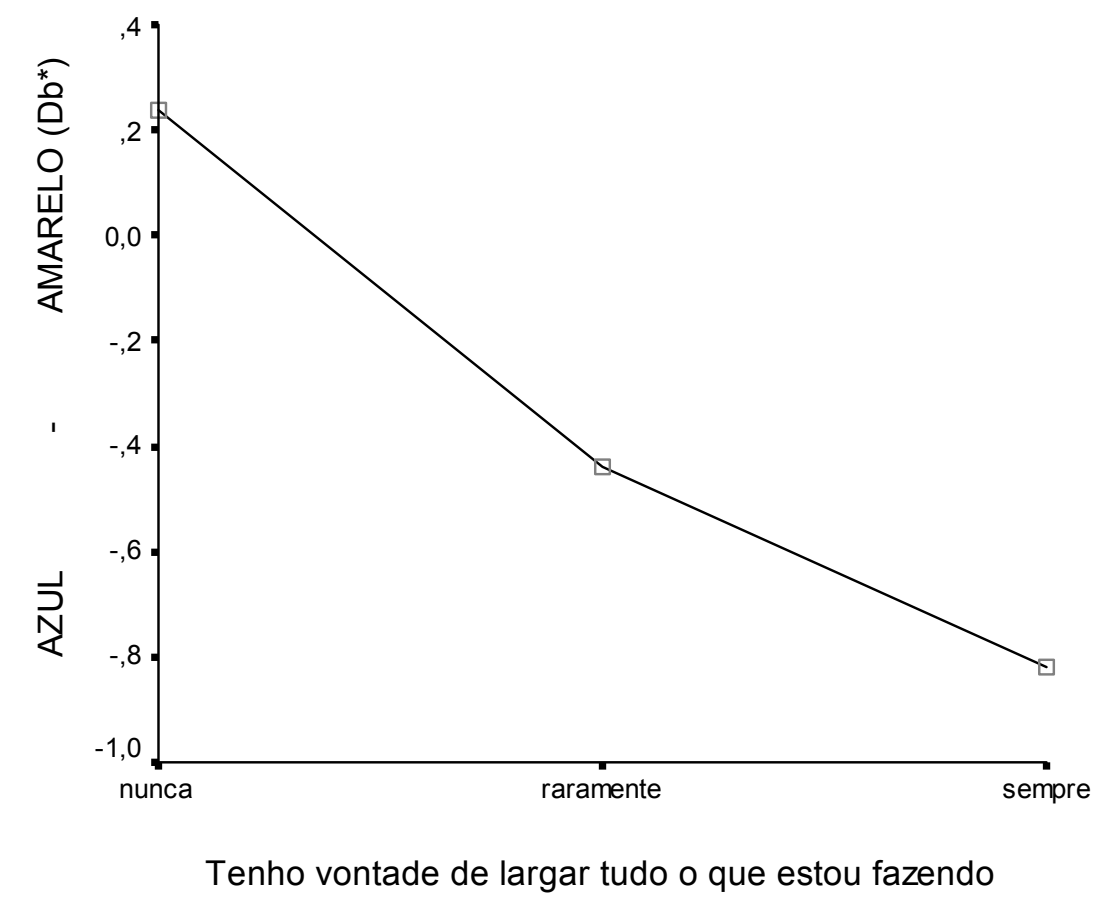

FIGURA 9 - Disposição dos atletas do Handebol em largar o esporte e a oscilação espectral da cor da pele $\mathrm{Db}^{*}$ (azul-amarelo) nas medições do braço 
Os dados da FIGURA 9 demonstram o tipo de associação $(p=0,006)$, entre o item LSS-VAS "Tenho vontade de largar tudo o que estou fazendo", com as variações $\mathrm{Db}^{*}$ (azul-amarelo) nas medições do braço. Significa que entre os 12 atletas: um $(8 \%)$ afirmou que sempre $\left(\mathbf{D b}^{*}-\mathbf{0 , 8 2}\right)$ tem o desejo de largar tudo; seis $(50 \%)$ afirmaram que raramente $\left(\mathrm{Db}^{*}-\mathbf{0}, \mathbf{4 3}\right)$ têm o desejo de largar tudo, entre os quais - um dos atletas convocados para os Jogos Olímpicos de Pequim 2008; cinco (42\%) afirmaram que nunca $\mathrm{Db}^{*} \mathbf{0 , 2 4}$ têm desejo de largar tudo o que estão fazendo, entre os quais, os outros dois atletas convocados para os Jogos Olímpicos.

Os dados põem em perspectiva que os atletas que manifestaram o desejo de largar tudo (raramente ou sempre), apresentaram a cor da pele significativamente menos amarelada em medições espectrais depois do treino, em relação aos que afirmaram que nunca sentiram o desejo de abandonar o esporte. Ou seja, que sentiam o desejo de largar tudo, tinham a cor da pele significativamente mais amarelada, antes da ativação do organismo pela corrida.

A correlação do amarelar da pele com o desejo de largar tudo denota a diminuição do interesse pelo esporte, um sintoma de estresse preocupante, pois sentimentos prolongados para abandonar o esporte podem ser vinculados ao estado de exaustão que caracteriza o abandono pela síndrome do burnout. Mas, os atletas poderiam estar se referindo apenas ao desejo de "abandonar" os trabalhos de coleta de dados. No entanto, o fato é pouco provável, pois em um chiste, um dos atletas comentou: "realmente deve existir uma 'ajudinha lá de cima"”, referindo que os pesquisadores haviam "salvo" os atletas com a proposição dos trabalhos de coleta de dados para a pesquisa, já que estavam muito cansados naquele dia.

O item LSS-VAS "Qualquer coisa me apavora" apresentou pela análise do coeficiente de Spearman $(p=0,012)$ correlação significativa acentuada com as diferenças de medições da cor da pele no braço $\left(\mathrm{Db}^{*}\right)$, pré e pós-treinos, consoante a representação dos dados destacados pela FIGURA 10. 


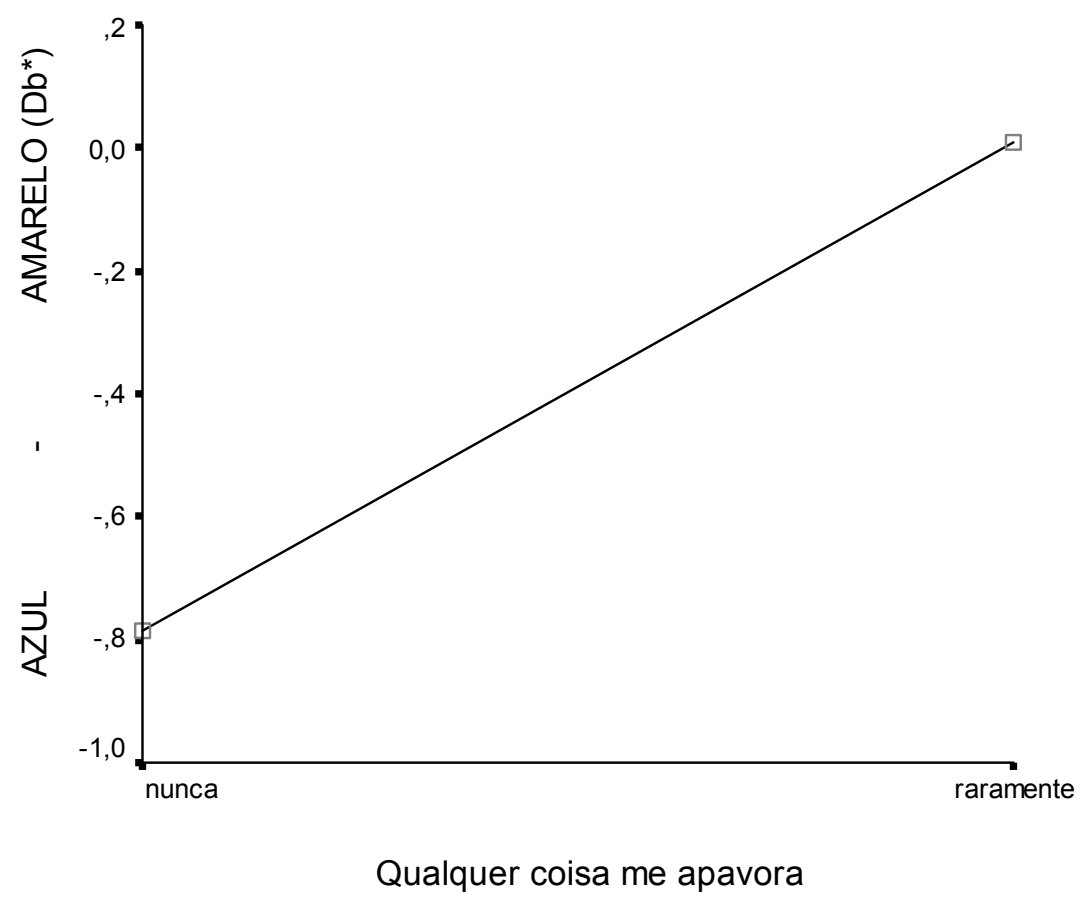

FIGURA 10 - Sentimentos de pavor entre os atletas do Handebol e a oscilação espectral da cor da pele $\mathrm{Db}^{*}$ (azul-amarelo) nas medições no braço

Conforme a FIGURA 10, os atletas que apresentaram a cor da pele menos amarelada depois do treino, assinalaram nunca sentir pavor, significa que dos 12 atletas pesquisados, três (25\%) afirmaram que (nunca) se sentiram apavorados diante de qualquer coisa ( $\left.\mathbf{D b}^{*}-\mathbf{0}, \mathbf{7 9}\right)$; e nove atletas $(75 \%)$ responderam que (raramente) sentem-se apavorados $\left(\mathbf{D b}^{*} \mathbf{0 , 1 0}\right)$; entre os quais os três atletas que foram convocados para as Olimpíadas de Pequim 2008.

O item LSS-VAS "Aperto às mandíbulas" apresentou pela análise do coeficiente de Spearman ( $p=0,012)$ correlação significativa com as diferenças de medições da cor da pele no braço $\left(\mathrm{Db}^{*}\right)$, pré e pós-treinos, conforme a representação dos valores médios destacados pela FIGURA 11. 


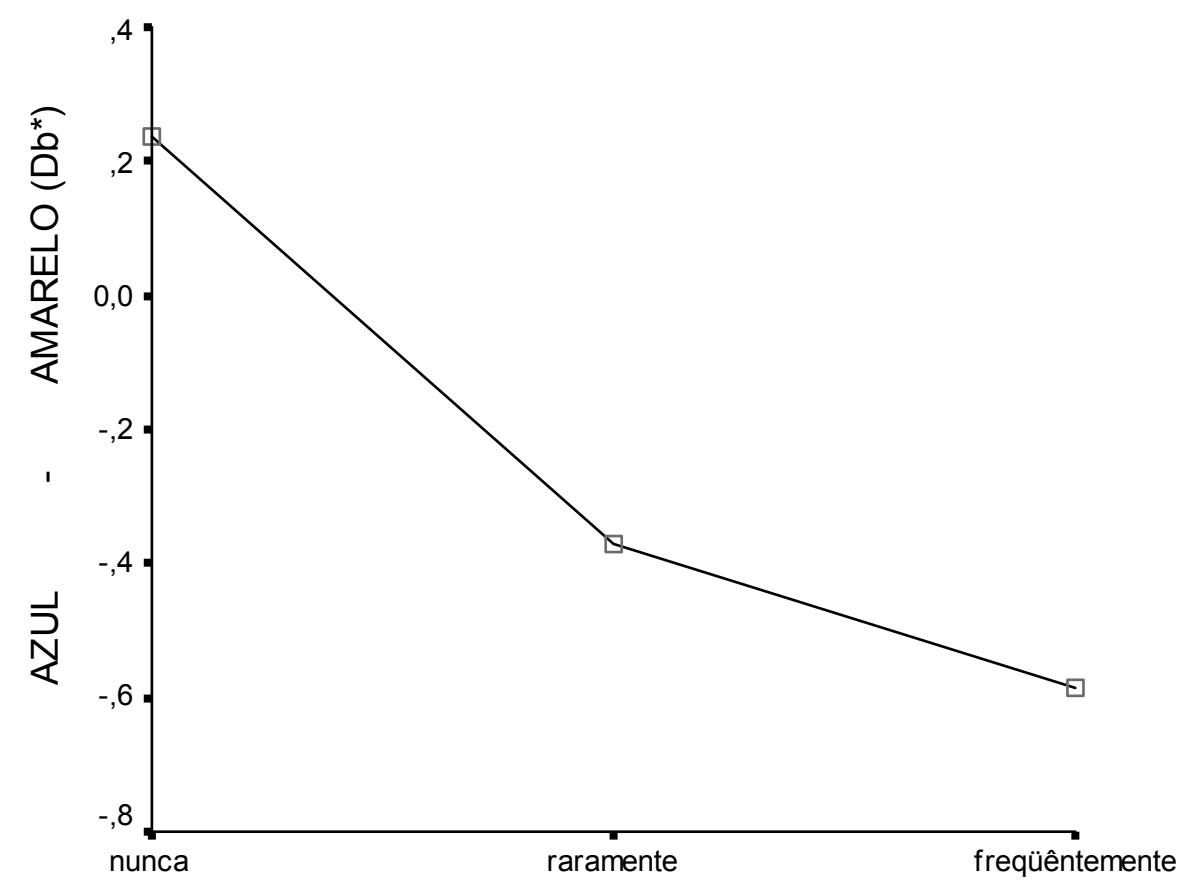

Aperto as mandíbulas

FIGURA 11 - Associação entre pressão orofacial e a oscilação espectral da cor da pele $\mathrm{Db}^{*}$ (azul-amarelo) no braço dos atletas do Handebol

A FIGURA 11 mostra o tipo de associação entre a pressão na mandíbula e a oscilação espectral da cor da pele $\left(\mathrm{Db}^{*}\right)$ significa que quatro atletas $33 \%$ revelaram que freqüentemente $\left(\mathbf{D b}^{*}-\mathbf{0 , 6 7}\right)$; três $(25 \%)$ raramente $\left(\mathbf{D b}^{*}-\mathbf{0 , 3 7}\right)$ e cinco $42 \%$ nunca $\left(\mathbf{D b}^{*} \mathbf{0 , 2 3 8}\right)$ apertam a mandíbula. Os resultados colocam em evidência que os atletas que afirmaram apertar a mandíbula com maior freqüência, apresentavam a cor da pele significativamente mais amarelada antes da corrida, em relação aos que disseram nunca apertar a mandíbula.

O item LSS-VAS "Meu apetite oscila muito" pela análise do coeficiente de Spearman $(p=0,015)$ apresentou uma correlação significativa com as diferenças de medições espectrais da cor da pele no braço $\left(\mathrm{Db}^{*}\right)$, pré e pós-treinos, conforme a representação dos dados destacados pela FIGURA 12. 


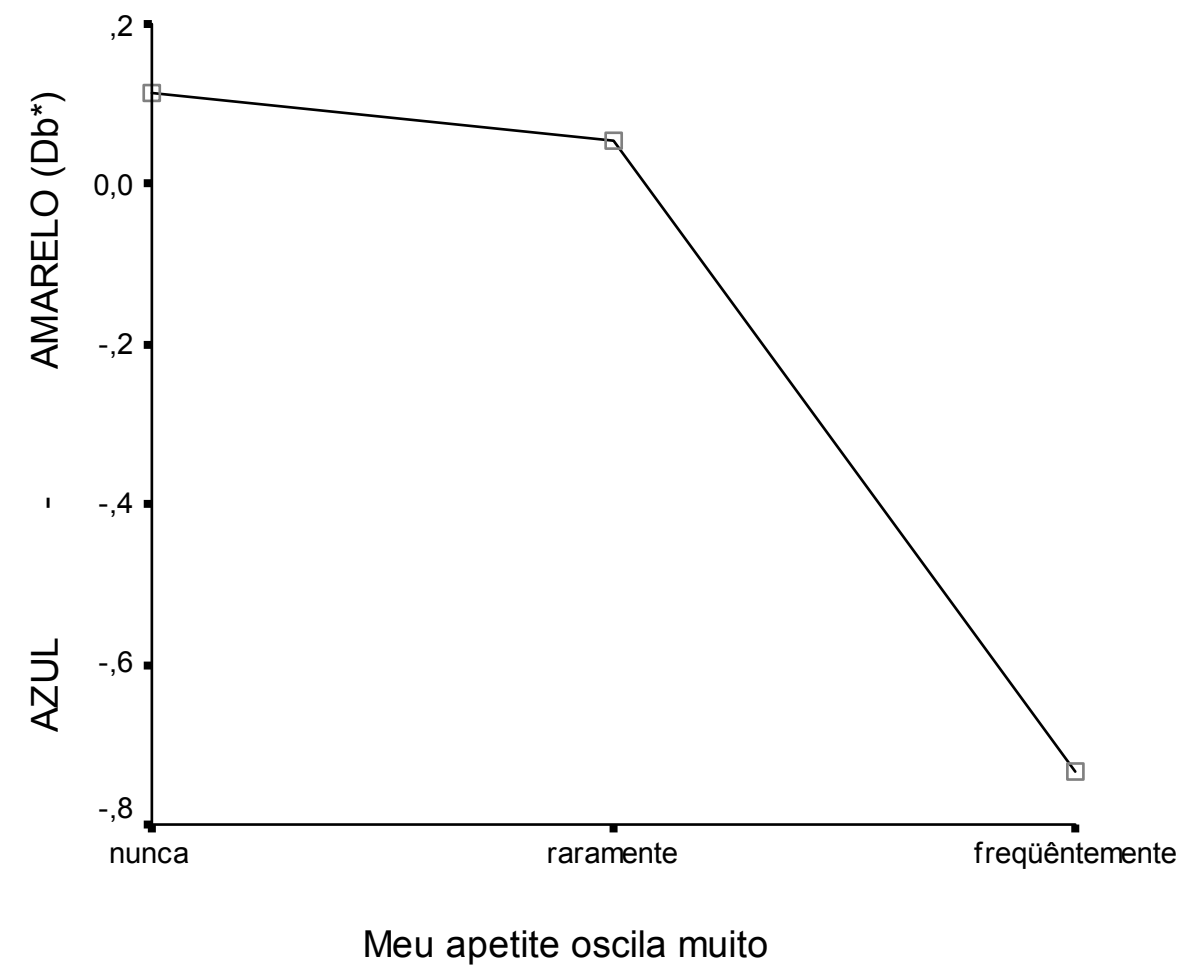

FIGURA 12 - Associação entre oscilação do apetite e oscilação espectral Db* (azul-amarelo) em mediç̃es no braço do atletas do Handebol

A FIGURA 12 demonstra o tipo de associação entre a oscilação espectral da cor da pele $\mathrm{Db}^{*}$ e a oscilação de apetite. Assim, quatro atletas (33\%) afirmaram que com frequência $\left(\mathbf{D b}^{*}-\mathbf{0}, \mathbf{7 3}\right)$ têm oscilações do apetite e revelaram a cor da pele significativamente menos amarelada depois da corrida, em relação aos quatro atletas $\left(\mathbf{D b}^{*}-\mathbf{0 , 0 6}\right)$ que afirmaram raramente $(33 \%)$, e aos quatro $(\mathbf{D b *} \mathbf{0 , 1 1})$ que disseram nunca ter oscilação do apetite (33\%). 


\subsubsection{Análise das correlações mais fortes, obtidas entre a oscilação espectral da cor da pele dos atletas do Handebol $\mathrm{Db}^{*}$ no braço e intensidade de sintomas de estresse LSS-VAS}

A divisão em quartis da intensidade total de sintomas de estresse LSS-VAS, seguiu a orientação do Prof. Dr. Esdras Guerreiro Vasconcellos ${ }^{25}$ sobre distribuição do estresse na população, com base em diversos estudos que mostraram que a baixa intensidade de sintomas de estresse corresponde a $13 \%$, assim valores iguais ou inferiores a 34,5 compreenderam o primeiro quartil, denota baixa intensidade do sintoma de estresse; segundo quartil, valor de 35 a 111, denota média intensidade, terceiro quartil, valor de 112 a 188, denota alta intensidade; e o quarto, valor entre 189 e 265,5, denota altíssima intensidade dos sintomas de estresse.

A intensidade dos sintomas de estresse dos atletas do Handebol mostrou que cinco jogadores $(41,67 \%)$ apresentavam baixa intensidade de sintoma de estresse (primeiro quartil); seis (50\%) apresentavam média intensidade (segundo quartil); e um atleta $(8,33 \%)$ altíssima intensidade de sintomas de estresse.

$O$ resultado da análise pelo coeficiente da correlação de Spearman como aparece nos dados da TABELA 3 sobre a intensidade de sintomas de estresse e os deltas das diferenças de cor da pele $\mathrm{Db}^{*}$ (azul-amarelo) nas medições no braço mostrou correlação significativa acentuada com a intensidade parcial $(p=\underline{\mathbf{0 , 0 0 6}}) \mathrm{e}$ a intensidade total $(p=\underline{0,000})$.

A análise da associação entre a oscilação da cor da pele $\mathrm{Db}^{*}$ (azul-amarelo), nas medições no braço e intensidade de sintomas de estresse que apresentaram as dez correlações mais fortes foram: "sinto angústia" ( $p=0,004)$; "costumo faltar ao trabalho" ( $p=0,005)$; "sinto dores nas costas" $(p=0,002)$; "qualquer coisa me irrita" $(p=0,003)$; "sinto exaustão física" $(p=0,002)$; "sinto pressão no peito" $(p=0,003)$; "tenho pesadelos" ( $p=0,007)$; "tenho um nó no estômago" ( $p=0,010)$; "tenho dúvidas sobre mim mesmo $(a)$ " ( $p=0,002)$; "tenho vontade de largar tudo o que estou fazendo" ( $(=0,003)$, conforme os dados destacados pela FIGURA 13.

${ }^{25}$ Comunicação pessoal 


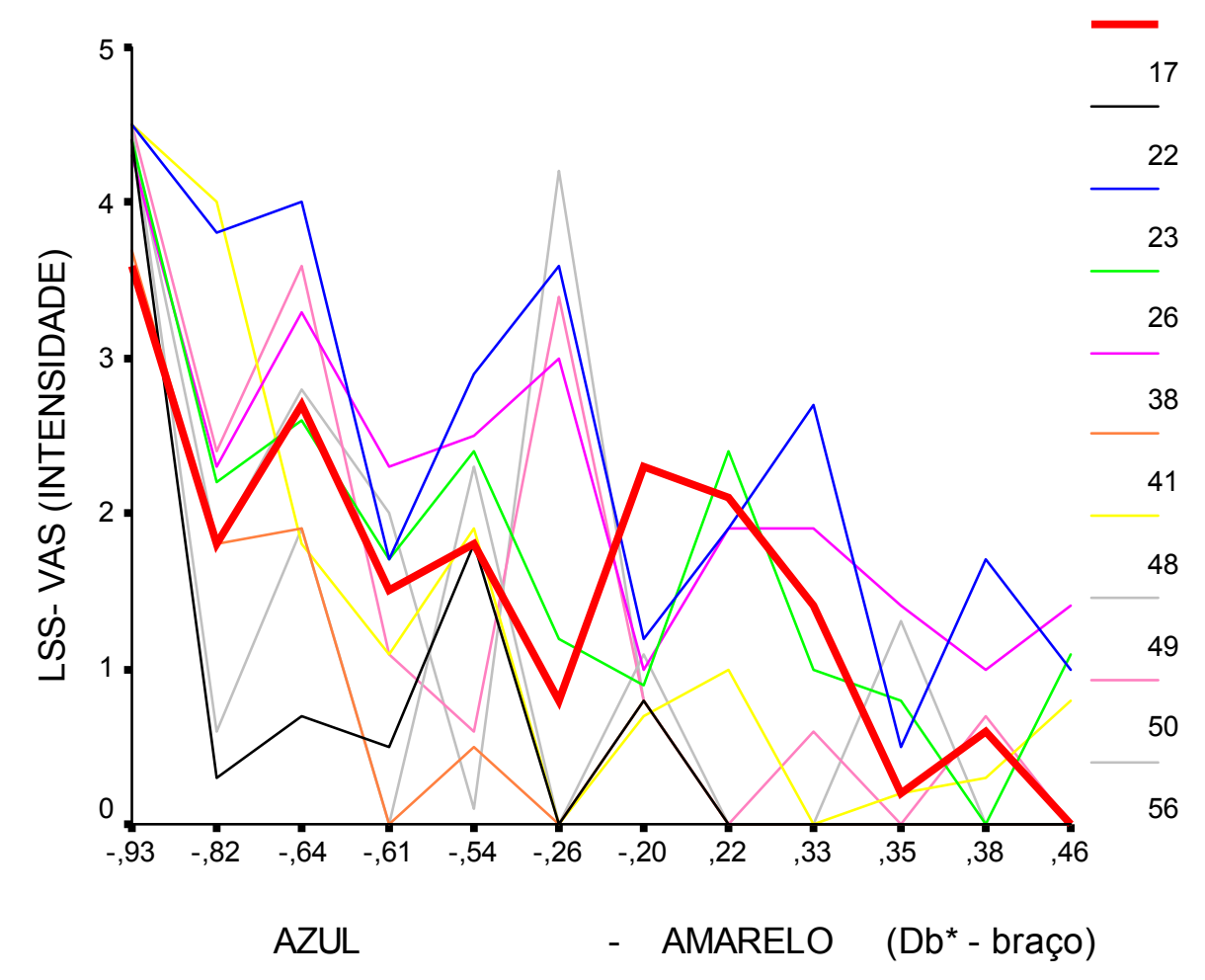

FIGURA 13 - Associação das correlações mais fortes da intensidade dos sintomas de estresse (LSS-VAS) e a oscilação espectral $\mathrm{Db}^{*}$ (azul-amarelo) no braço dos atletas do Handebol

A FIGURA 13 demonstra o tipo de associação entre oscilação espectral da cor da pele $\mathrm{Db}^{*}$ (azul-amarelo) no braço dos atletas do Handebol e a intensidade de sintomas de estresse $(\mathbf{p}=0,000)$ nos dez itens que apresentaram as correlações mais fortes. Isto evidencia que os atletas, com a cor da pele significativamente mais amarelada antes do treino, sentiam: maior angústia (17), faltavam aos jogos e treinamentos (22), tinham dores nas costas (23), sentiam-se irritados por qualquer coisa (26), exaustão física (38), pressão no peito (41), pesadelos (48), nó no estômago (49), dúvidas sobre si próprio (50) e vontade de largar tudo (56). Resultados favoráveis à hipótese do "amarelão". 


\subsubsection{Análise das correlações mais fortes obtidas entre a oscilação espectral da cor da pele dos atletas do Handebol DL*no rosto e freqüência de sintomas de estresse LSS-VAS}

Os dados apresentados na TABELA 3 mostram uma correlação significativa

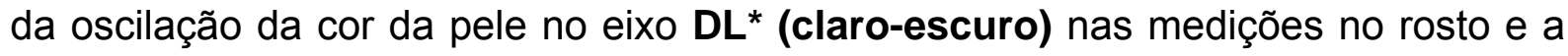
freqüência de sintomas de estresse LSS-VAS: parcial $(p=0,046)$ e total $(p=\underline{0,008})$. A oscilação da cor da pele $\mathrm{DL}^{*}$ no rosto e as freqüências: parciais e totais dos sintomas de estresse são destacadas pela FIGURA 14.

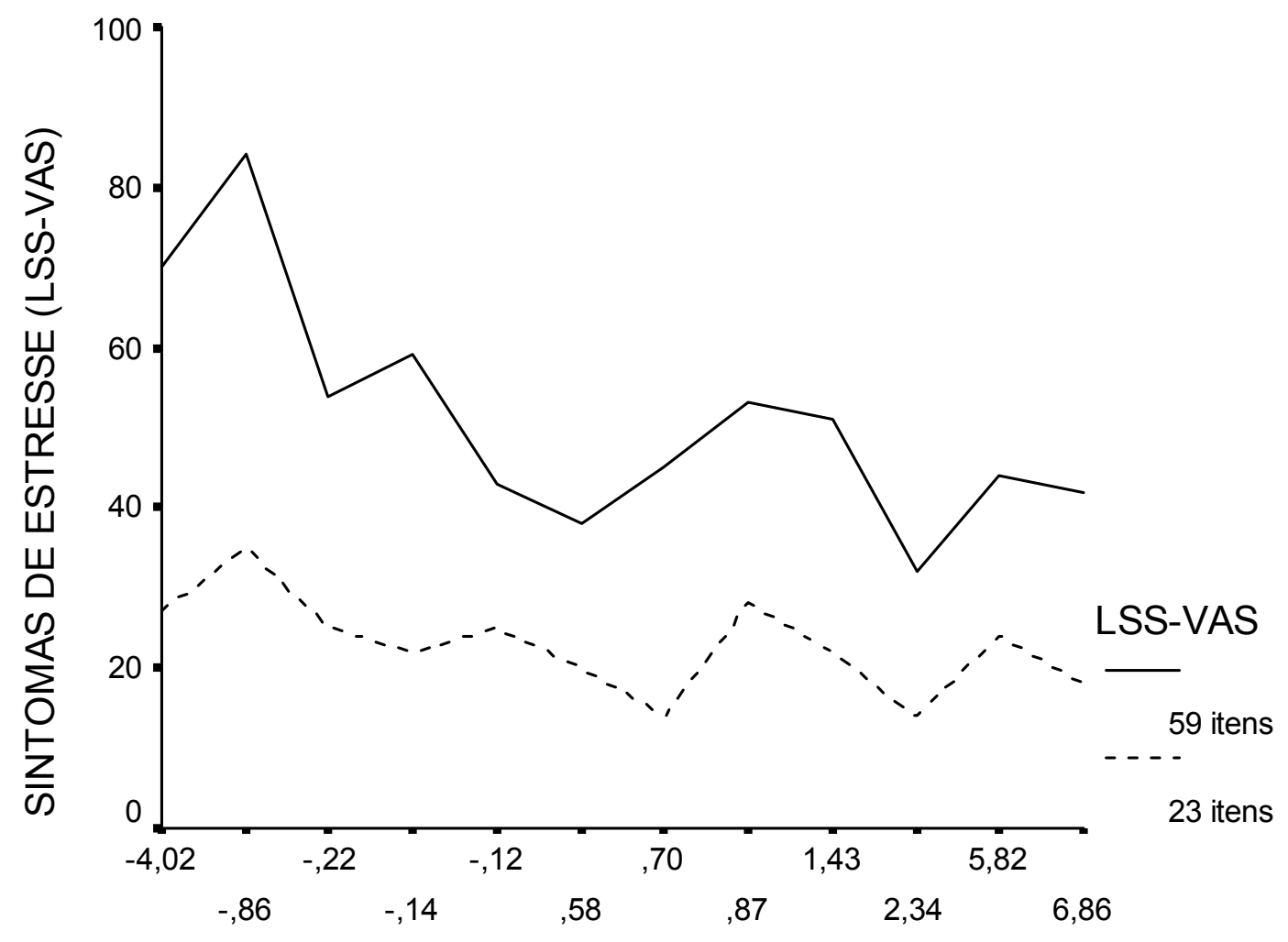

DIFERENÇAS ESPECTRAIS DL (ESCURO - CLARO)

FIGURA 14 - Oscilação espectral DL* (claro-escuro) pré e pós-treinos dos atletas do Handebol e a freqüência de sintomas de estresse (LSS-VAS) 
A FIGURA 14 evidencia que os valores mais elevados da intensidade dos sintomas de estresse LSS-VAS correlacionam-se com os valores mais negativos de $\left(D L^{*}\right)$, ou seja, os atletas que revelaram valores mais elevados de intensidade dos sintomas de estresse, apresentavam a cor da pele significativamente mais clara (pálidos) antes do treino. Achado que, também, é favorável à hipótese do "amarelão", pois palidez no olhar do leigo está associada com o amarelar.

A oscilação espectral $D^{*}$ no rosto, além de refletir a oscilação da cor da pele dos atletas pelas disposições orgânicas e psicológicas, mostra oscilações da cor pela exposição do rosto ao sol no verão brasileiro, por volta das 12 horas, durante 20 minutos. Por isso, as medidas apresentaram maior amplitude que as registradas no braço (sem exposição ao sol).

Desse modo, os valores mais negativos de $\mathrm{DL}^{*}, \mathrm{Da}^{*}$ e $\mathrm{Db}^{*}$ indicam, respectivamente, que a cor da pele dos atletas, depois do treino, ficou menos clara, menos vermelha e menos amarela, depois do treino em consonância com as disposições físicas ambientais, fisiológicas e psicológicas.

As características da associação entre a oscilação da cor da pele $\mathrm{DL}^{*}$ (rosto) e a freqüência de sintomas de estresse foi analisada pelos itens que apresentaram as correlações mais fortes $(p<0,02)$ : "Quando me levanto de manhã já estou cansado" ( $p=0,001)$; "Sinto que meu desempenho no trabalho está limitado" ( $p=$ $0,001)$; "Qualquer coisa me irrita", ( $(=0,004)$; e, "Sinto pressão no peito", $(p=0,009)$.

A oscilação espectral da cor da pele $\mathrm{DL}^{*}$ (claro-escuro) também pode implicar características importantes da oscilação da cor da pele na relação com o estresse, tais como, a textura, o brilho, a opacidade, entre outras "cesías", conforme denominaram CAIVANO; MENGH e LADISERNIA (2006). 


\subsubsection{Análise das correlações mais fortes obtidas entre a oscilação espectral da cor da pele dos atletas do Handebol $\mathrm{DL}^{*}$ no rosto e intensidade de sintomas de estresse LSS-VAS}

Os dados apresentados na TABELA 3 mostraram que não houve correlação significativa da oscilação da cor da pele no eixo $\mathrm{DL}^{*}$ nas medições rosto e a intensidade parcial $(p=0,416)$ e total $(p=0,265)$. Entretanto, a oscilação da cor da pele no rosto dos atletas do Handebol pelas medidas espectrais $D L^{*}$ (claro-escuro) e a intensidade de sintomas de estresse variou, consoante a curva apresentada pela FIGURA 15.

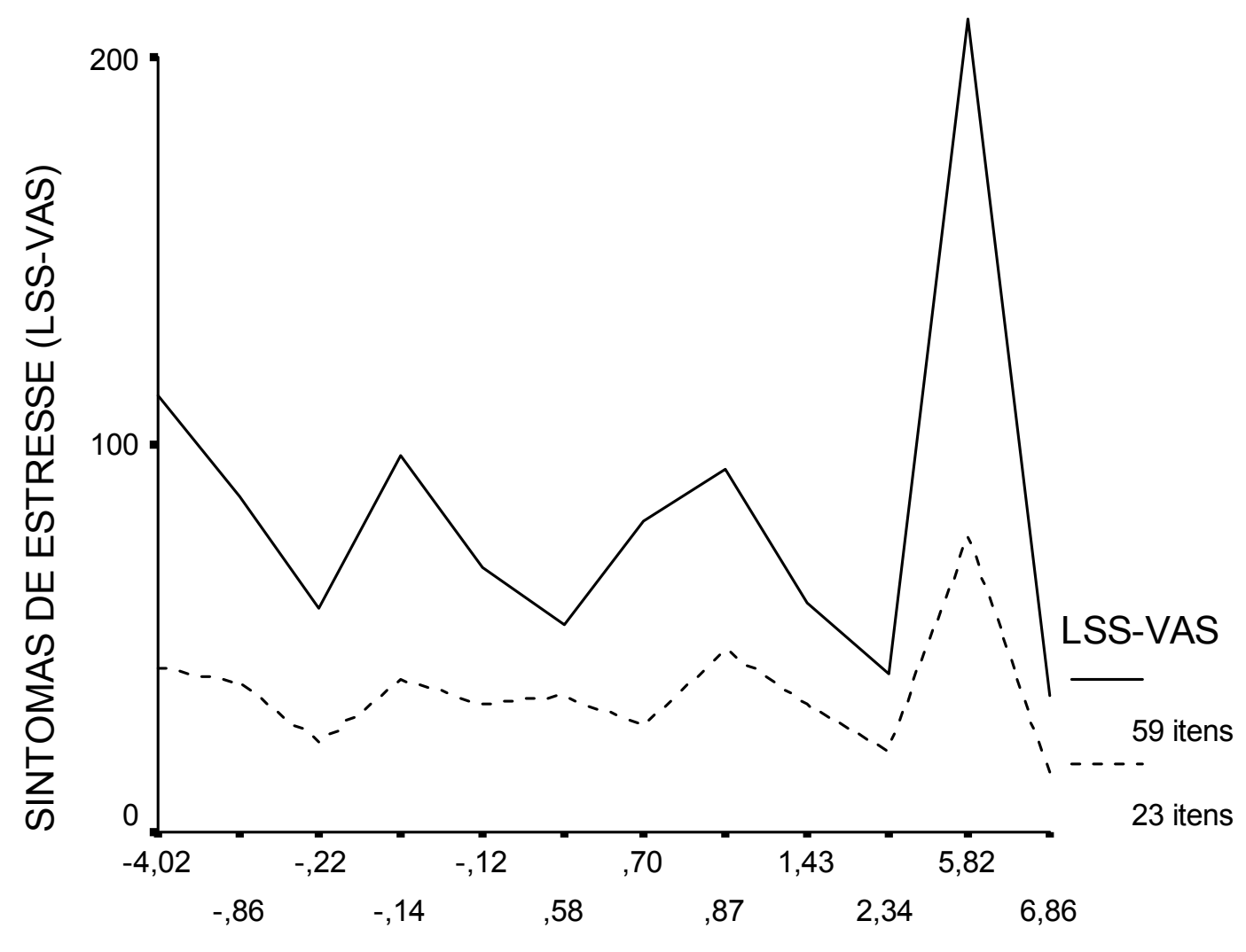

DIFERENÇAS ESPECTRAIS DL (ESCURO-CLARO)

FIGURA 15 - Valores espectrais $\mathrm{DL}^{*}$ (claro-escuro) no rosto dos atletas do Handebol e a intensidade dos sintomas de estresse (LSS-VAS) 
Na FIGURA 15, destaca-se o atleta que apresentou altíssima intensidade de sintomas de estresse (quarto quartil). Mas, poderia estar distorcendo a análise parcial $(p=0,416)$ e total $(p=0,265)$. Entretanto, uma análise que considera aspectos qualitativos e quantitativos não pode desconsiderar um atleta que mostrou altíssima intensidade de sintomas de estresse.

O comportamento desse atleta chamou atenção pelo fato de suas respostas terem apresentado certa sistematização. Os oito itens que assinalaram alta freqüência estão entre os que constam na primeira das três paginas da LSS-VAS. Entretanto, não revelou dados no item quatro: "Tenho a sensação que vou desmaiar". Na segunda página, assinalou altíssima freqüência em todos os itens, mas não assinalou três itens: "Ouço zumbidos no ouvido"; "Sinto o corpo coberto de suor frio"; e "Sinto os olhos lacrimejantes e visão embaçada".

Nos trabalhos de coleta, o caso chamou atenção, porque em um "chiste" um dos atletas observou que o local onde ele sentou-se, enquanto aguardava as medições pós-treinos, formou uma poça de suor com formato peculiar, por isso, os outros riram dele. O fato evidencia que a intensidade dos sintomas de estresse desse atleta poderia apresentar valores ainda mais elevados ou que os valores apurados eram consistentes, pois os dados não revelados poderiam ter sido compensados pela irritação ao assinalar os outros itens com intensidade máxima.

A análise dos deltas das diferenças da cor da pele das medições no rosto por meio dos valores espectrais $\mathrm{DL}^{*}$ (claro-escuro) e dos resultados obtidos sobre a freqüência de sintomas de estresse, mediante a exclusão do atleta que apresentou altíssima freqüência de sintomas, mostrou os seguintes dados: $D L^{*}$ freqüência parcial $(p=0,416), D L^{*}$ freqüência total $(p=0,029)$; evidenciando correlação significativa entre $D^{*}$ e a freqüência total da intensidade de sintomas de estresse.

Com base na análise dos dados até este ponto, podemos afirmar preliminarmente que os dados obtidos dos atletas do Handebol são favoráveis à hipótese do amarelão, pois a oscilação espectral da cor da pele Db* (azul-amarelo) nas medições no braço (pré e pós-treinos ); e a oscilação espectral da cor da pele DL* (claro-escuro) nas medições no rosto (pré e pós-treinos ), são concernentes às hipóteses de pesquisa sobre a relação entre "amarelão" e sintomas de estresse. 


\subsubsection{Expectativas do lócus do controle dos atletas do Handebol por meio da Escala Multidimensional de Lócus de Controle do esporte (EMLCE)}

Ao dar continuidade à busca por esclarecimentos das hipóteses de pesquisa, são apresentados os dados obtidos pela aplicação da Escala Multidimensional de Lócus de Controle de Esporte (EMLCE) aos atletas do Handebol de alto rendimento. Os escores do lócus de controle da EMLCE podem variar nos domínios: interno, externos sorte-azar e pessoas poderosas em uma amplitude de zero a 48.

Considerando-se uma distribuição equitativa do lócus de controle, o primeiro quartil correspondeu a 25\%, que compreende valores iguais ou inferiores a 12 , denota baixos escores. O segundo quartil compreende valores de 13 a 24 que denota média baixa. O terceiro quartil, valores de 25 a 36 que valor médio. E o quarto, valores de 37 e 48 denotam altos escores. As estatísticas descritivas das expectativas do lócus de controle: valores mínimos, máximos, médias e desviopadrão são apresentados na TABELA 4.

TABELA 4 - Expectativas do lócus de controle de atletas do Handebol de alto desempenho

\begin{tabular}{lrrrrr}
\hline \hline & $\mathrm{N}$ & Mínimo & Máximo & Média & $\begin{array}{l}\text { Desvio- } \\
\text { padrão }\end{array}$ \\
\hline $\begin{array}{l}\text { Lócus de controle interno } \\
(\text { LCl })\end{array}$ & 12 & 26 & 42 & 35,75 & 4,97 \\
$\begin{array}{l}\text { Lócus de controle extreno } \\
\text { sorte-azar (LCE-SA) } \\
\text { Lócus de controle extreno } \\
\text { pessoas poderosas } \\
\text { (LCE-PP) }\end{array}$ & 12 & 13 & 35 & 20,17 & 6,46 \\
Casos válidos & 12 & 10 & 36 & 20,58 & 7,27 \\
\hline \hline
\end{tabular}

Fonte: Arquivo do pesquisador

Os dados da TABELA 4 mostram os escores de lócus de controle obtidos dos atletas do Handebol de alto desempenho nos domínios: lócus de controle interno LCI 35,75 (média alta de lócus de controle interno); lócus de controle externo sorte- 
azar LCE-AS 20,17 (média baixa de lócus de controle externo sorte azar); e lócus de controle externo pessoas poderosas LCE-PP 20,58 (média baixa de lócus de controle externo pessoas poderosas).

Esses valores aproximam-se dos dados obtidos pela construção da escala de Lócus de Controle do Esporte, cuja amostra constituiu-se de 111 atletas do Handebol, entre os quais são os atletas da equipe pesquisada neste estudo: lócus de controle interno ( $\mathrm{LCl}$ 33,32); lócus de controle externo sorte-azar (LCE-SA 24,27); e lócus de controle externo pessoas poderosas (LCE-PP 24,11), CONCEIÇÃO (2004).

Os resultados do lócus de controle mostram que houve repetitibilídade dos escores e confirmam a tendência de média alta de escores de lócus de controle interno dos atletas do Handebol de alto desempenho. A noção geral dos escores mais elevados de lócus de controle interno associa-se ao alto desempenho em diversas esferas de atuação do ser humano, entre as quais: a saúde, a administração, a economia e o esporte, entre outras.

O cruzamento interno das três subescalas de Lócus de Controle do Esporte (EMLCE) mostrou pela análise do coeficiente de Pearson correlação significativa ( $p=$ 0,002) entre o lócus de controle externo sorte-azar e o lócus de controle externo pessoas poderosas, dados que reproduzem achados encontrados por outros pesquisadores responsáveis pela discussão sobre a multidimensionalidade ou a unidimensionalidade do conceito de lócus de controle. Apesar dessa discussão, verifica-se tendência entre os pesquisadores de lócus de controle desenhar escalas para áreas especificas, dado que o conceito unidimensional de lócus de controle é muito amplo, exemplo disso, os estudos envolvendo lócus de controle da saúde, a partir de 1980, que culminaram na Multidimentional Helth Locu of Control (MHLC), adaptada no Brasil por DELA COLETA (2004). 


\subsubsection{Análise da correlação entre lócus do controle e a oscilação espectral da cor da pele dos atletas do Handebol de alto desempenho}

Ao objetivar-se a hipótese de pesquisa das oscilações cromáticas da cor ( $L^{*}$, $a^{*}, b^{* 26}$ ) dos atletas do Handebol, pelo método espectrofotométrico, alinhadas ao lócus de controle dos atletas de alto rendimento. Os dados obtidos do coeficiente de correlação de Spearman são mostrados na TABELA 5.

TABELA 5 - Análise de correlação entre lócus do controle e $\quad$ a oscilação espectral da cor da pele dos atletas do Handebol no braço e no rosto

\begin{tabular}{llrrr}
\hline \hline & & $\mathrm{LCl}$ & LCE-SA & LCE-PP \\
\hline $\mathrm{DL}$ (braço) & Coeficiente &,- 562 &, 042 &, 123 \\
& Significância &, 057 &, 896 &, 703 \\
& $\mathrm{~N}$ & 12 & 12 & 12 \\
\hline $\mathrm{Da}^{*}$ (braço) & Coeficiente &, 355 &, 025 &,- 144 \\
& Significância &, 257 &, 939 &, 655 \\
& $\mathrm{~N}$ & 12 & 12 & 12 \\
\hline $\mathrm{Db}^{*}$ (braço) & Coeficiente &,- 141 &, 208 &, 190 \\
& Significância &, 663 &, 516 &, 555 \\
& $\mathrm{~N}$ & 12 & 12 & 12 \\
\hline $\mathrm{DL}$ (rosto) & Coeficiente &, 288 &, 152 &,- 067 \\
& Significância &, 364 &, 638 &, 837 \\
& $\mathrm{~N}$ & 12 & 12 & 12 \\
\hline $\mathrm{D}^{*}$ (rosto) & Coeficiente &,- 056 &,- 046 &,- 155 \\
& Significância &, 862 &, 887 &, 631 \\
& $\mathrm{~N}$ & 12 & 12 & 12 \\
\hline $\mathrm{Db}^{*}$ (rosto) & Coeficiente &, 299 &, 240 &,- 183 \\
& Significância &, 346 &, 453 &, 570 \\
& $\mathrm{~N}$ & 12 & 12 & 12 \\
\hline \hline
\end{tabular}

\footnotetext{
${ }^{26} \mathrm{CIE} \mathrm{L}^{*} \mathrm{a}^{*} \mathrm{~b}^{*}$ - unidades de medida de cor proposto pelo Commission Internationale de E'clairege com base na teoria de absorção e reflexão da luz, ver FIGURA 5, p. 42: L* (claro-escuro); a* (vermelho-verde); b* (azulamarelo). Os deltas das diferenças das oscilações da cor da pele foram calculados subtraindo-se os valores obtidos nas medições pós-treino das medições pré-treino.
} 
$\mathrm{Na}$ TABELA 5, os dados mostram que não houve correlação significativa da oscilação espectral nas dimensões da cor definidas pelo espaço CIE $L^{*} a^{*} b^{*}$ no rosto e no braço pré e pós-treinos s: $\mathrm{DL}^{*}$, $\mathrm{Da}^{*}$ e $\mathrm{Db}^{*}$; com as dimensões do lócus de controle: interno (LCI), externo sorte-azar (LCE-SA) e pessoas poderosas (LCE-PP)

O resultado desta análise coloca em perspectiva uma das características intrínsecas ao conceito de lócus do controle que tange à concepção de expectativas, (Generalized Expectancies), um constructo amplo no escopo da teoria de aprendizagem social, que busca prever o comportamento, mas este como orientação geral da pessoa, ou seja, no longo prazo (ROTTER, CHANCE e PHARES, 1972).

\subsubsection{Análise da associação entre lócus do controle e sintomas de estresse dos atletas do Handebol de alto desempenho}

A seguir, são analisados os dados obtidos sobre lócus de controle e a freqüência de sintomas de estresse. A análise pelo coeficiente de Spearman apresentou os seguintes resultados: LCI - p 0,939 ; LCE S-A - p 0,785; LCE PP - p 0,786, mostrando que não houve correlações entre as três dimensões do lócus de controle e a freqüência total de sintomas de estresse.

Muito embora os dados não tenham mostrado correlação entre lócus de controle e freqüência de sintomas de estresse, a análise por itens mostrou correlação significativa com os itens: sinto a respiração ofegante $(p=\mathbf{0 , 0 3 2})$, os atletas com maiores escores de lócus de controle interno mostraram a respiração ofegante com maior freqüência; Tenho taquicardia $(\mathbf{p}=\mathbf{0 , 0 4 0})$, os atletas com maiores escores de lócus de controle interno mostraram que nunca têm taquicardia; Tenho a sensação que vou desmaiar $(\mathbf{p}=\mathbf{0 , 0 4 4})$, os atletas com maiores escores de lócus de controle interno mostraram que têm a sensação de que vão desmaiar com maior freqüência; Tenho insônia $(p=\mathbf{0 , 0 3 0})$, os atletas com maiores escores de lócus de controle interno mostraram que nunca têm insônia).

A análise pelo coeficiente de Spearman dos valores obtidos sobre a intensidade de sintomas de estresse LSS-VAS e as três dimensões do lócus de 
controle apresentou os seguintes resultados: $\operatorname{LCl}(p=0,883), \operatorname{LCE} S-A(p=0,320)$; LCE PP $(p=0,219)$. Mostrou que não houve correlação significativa entre as dimensões do lócus de controle e o somatório da intensidade da LSS-VAS.

Embora os dados não tenham mostrado correlação, a análise da intensidade pelo coeficiente de Spearman por itens mostrou correlação significativa do lócus de controle interno ( $\mathrm{LCl}$ ) e o item: "Tenho a sensação que vou desmaiar" ( $p=0,006)$, os atletas com maiores escores de lócus de controle interno mostraram ter a sensação que irão desmaiar com maior intensidade "amarelão". Lócus de controle sorte-azar e os itens: "Tenho medo" ( $\mathbf{p}=\mathbf{0 , 0 3 0}$ ), os atletas com maiores escores lócus de controle externo sorte-azar, mostraram tendência para menor intensidade de medo);

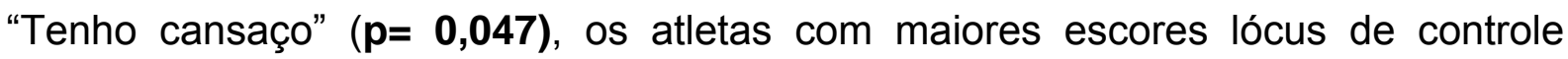
externo sorte-azar, mostraram tendência para menor intensidade de cansaço. Lócus de controle pessoas poderosas e os itens: "Não tenho vontade de fazer as coisas" $(p=\mathbf{0}, \mathbf{0 3 4})$, os atletas com menores escores lócus de controle externo pessoas poderosas, mostraram não ter vontade de não fazer as coisas com maior

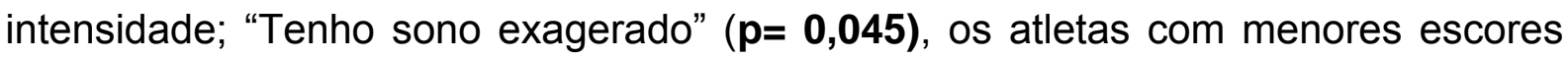
lócus de controle externo pessoas poderosas, mostraram tendência para o sono exagerado com maior intensidade); e, "Tenho dor de cabeça" ( $p=0,011)$, os atletas com menores escores lócus de controle externo pessoas poderosas mostraram ter dor de cabeça com maior intensidade.

Os dados obtidos sobre o lócus de controle dos atletas do Handebol de alto desempenho permitem inferir preliminarmente que o lócus de controle interno denota estar associado ao comportamento geral: Generalized Expectancies, nos termos referidos por ROTTER, CHANCE e PHARES (1972).

Estas inferências parecem se fortalecer em face da correlação $(p=0,001)$, obtida entre lócus de controle interno e a questão formulada por COELHO (2002), sobre a satisfação com o desempenho inserida nas informações dos dados gerais das características sociotécnicas dos atletas. Mostraram que os atletas que atribuíram pouca satisfação a seu desempenho obtiveram menores escores de lócus de controle interno. Os atletas que atribuíram: razoável e muita satisfação com seus desempenhos obtiveram os valores de lócus de controle interno mais elevado. 
Os dados obtidos pelas características sociotécnicas sobre o uso de medicamentos pelos atletas do Handebol de alto desempenho, também, mostraram correlação com o lócus de controle interno $(\mathbf{p}=\mathbf{0 , 0 1 1})$ : Seis dos 12 atletas $(50 \%)$ revelaram que não faziam uso de medicamentos e apresentaram menores escores médios de lócus de controle interno. Já, os atletas, os outros (50\%) que assinalaram fazer uso de medicamentos, apresentaram escores médios de lócus de controle interno significativamente mais elevados.

Os medicamentos listados pelos atletas foram: Sulfato de condroitina para reconstituição da cartilagem do joelho; o analgésico tylenol skin (oito em oito horas); analgésico a base de paracetamol; relaxante muscular (duas vezes por semana); remédios para pressão; dois atletas revelaram fazer uso de antiinflamatórios.

Até este ponto, os resultados obtidos com os atletas do Handebol denotam ser consistentes, dado que coloca em perspectiva que a regularidade da amostra e a qualidade do delineamento da pesquisa, podem, em alguns casos, ser mais importantes que uma amostra composta por um grande número de atletas com características muito diferentes e em condições diversas da pesquisa, especialmente, no caso de pesquisas que envolvem aspectos psicológicos e fisiológicos.

\subsubsection{Dados obtidos sobre as crenças religiosas dos atletas do Handebol pelas questões iniciais do Inventário Pratt de Crenças Religiosas no Esporte (IPCRE)}

A fim de esclarecer as hipóteses sobre estresse, oscilação da cor da pele e coping por crenças religiosas e lócus de controle, a seguir, são apresentados e, parcialmente analisados, os principais dados obtidos com os atletas do Handebol de alto desempenho, mediante a aplicação do Inventário Pratt de crenças religiosas no esporte IPCRE.

As concepções sobre os diferentes tipos de crenças religiosas: primitiva, intelectual, emocional, ético-moral e outros significados refletiram-se nas questões 
iniciais do IPCRE, distribuídas sob a forma de alternativas de múltipla escolha, sendo facultado aos atletas optar por mais de uma alternativa.

$\mathrm{Na}$ primeira questão, as diferentes modalidades de crenças religiosas são estruturadas sob a perspectiva da religião do atleta; na segunda, com base na representação de Deus; e na terceira, apoiada na sustentação da crença em Deus pelo atleta.

A seguir, são apresentados nas FIGURAS 16, 17 e 18 os resultados obtidos nas três questões iniciais do IPCRE:

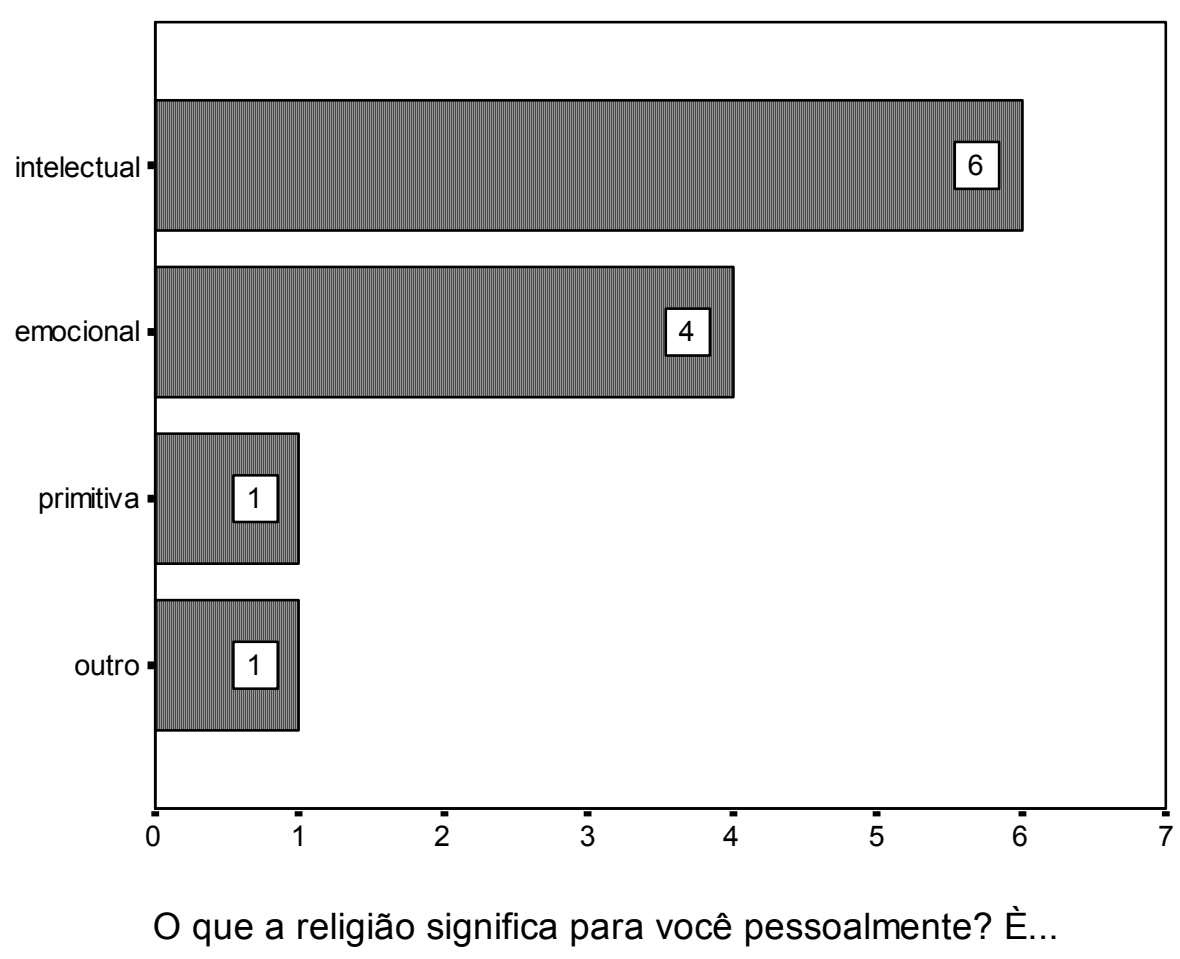

FIGURA 16 -Diferentes modalidades das crenças religiosas dos atletas do Handebol com base na perspectiva da religião 


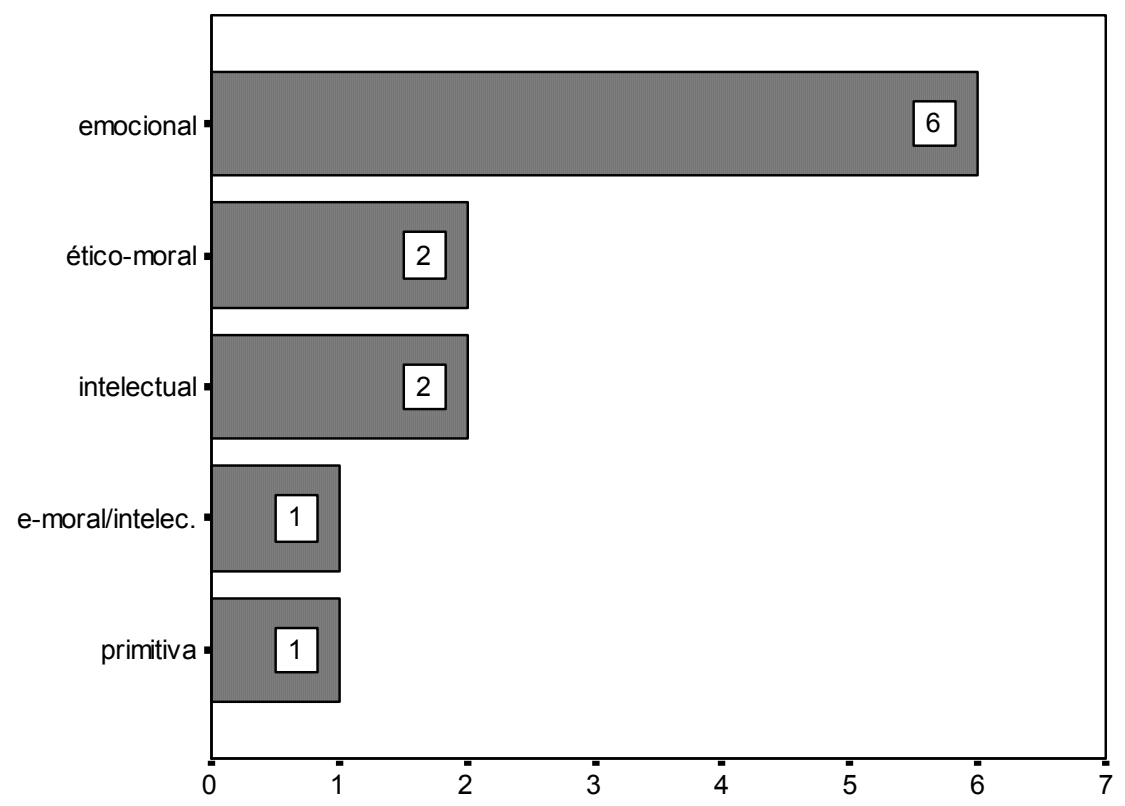

Como é Deus para você?

FIGURA 17 - Diferentes modalidades das crenças religiosas dos atletas do Handebol sob a perspectiva da representação de Deus

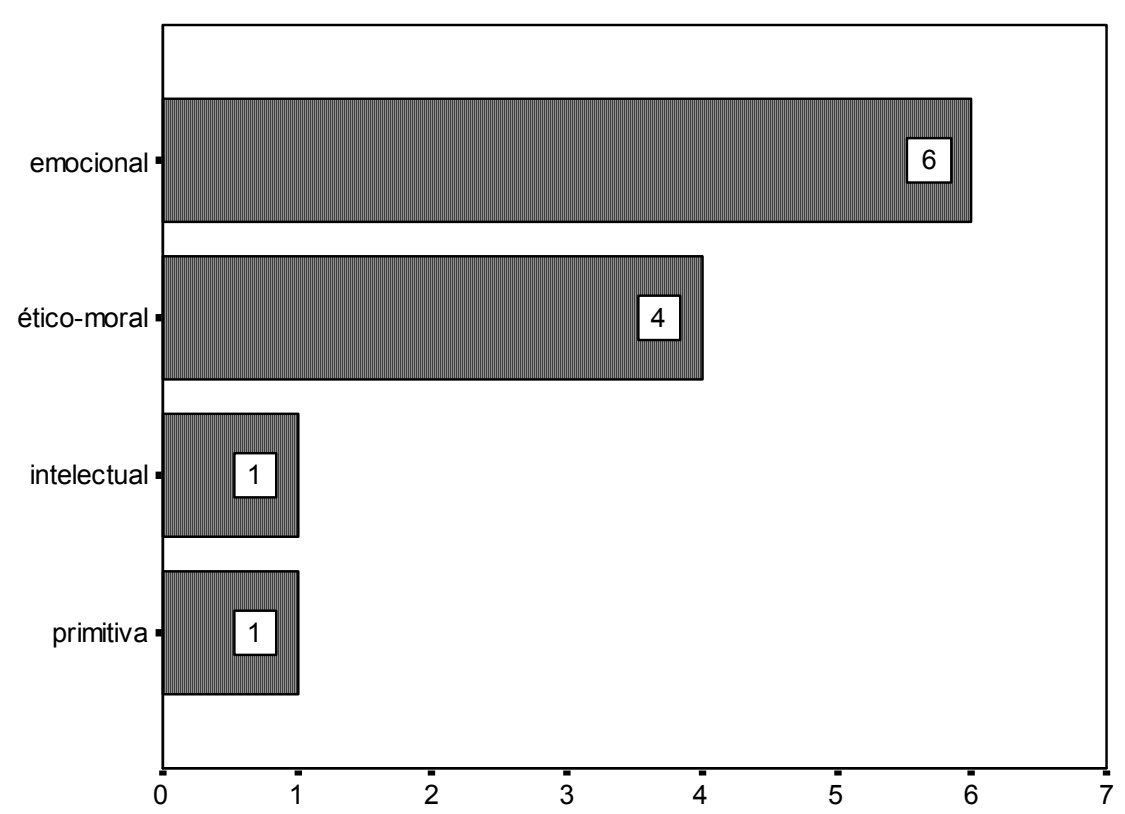

3- Você acredita em Deus? É...

FIGURA 18 - Diferentes modalidades das crenças religiosas dos atletas do Handebol sob a perspectiva da fundamentação da crença 
As diferentes modalidades de crenças religiosas são destacadas nas FIGURAS 16, 17 e 18 que mostram que a crença emocional foi assinalada 16 vezes $(44,44 \%)$ e surge como modalidade de crença prevalente entre os atletas do Handebol. Associada à sensação de estar vivo, conforme a percepção de Deus como: força da natureza, energia vital, harmonia natural das cores, respiração, entre outras representações que fornecem indicativos do tipo do coping que essa modalidade de crença possa oferecer aos atletas, obtidas por meio do Inventário Pratt de Crenças religiosas no Esporte, nos relatos dos atletas, ao complementarem a identificação de suas crenças religiosas com a alternativa que reflete a crença emocional na primeira questão:

\section{O que a religião significa para você pessoalmente? É...}

$\square \quad$ Uma crença de que algo existe? Descreva com é esta crença.

- Vivenciar, sentir e/ou experienciar a presença de Deus? Como é esta experiência?

$\square \quad$ Uma atitude do homem para difundir a idéia de Deus e as coisas que são corretas? Explique?

Respeitar as tradições e obedecer às figuras de autoridade? Quais?

Outro significado? Explique?

\section{Relatos dos atletas:}

- "O homem sente a presença de um ser superior pela disposição de ajudar o próximo e conviver em harmonia" (atleta16);

- "Acreditar que existe um ser acima, que pode nos ajudar" (atleta 17);

- "Um sentimento que dá mais confiança dos atos por saber que é Ele quem guia o caminho" (atleta 21);

- "São os arrepios e as emoções que sinto quando vou à igreja, o sentimento de estar protegido por uma coisa divina e espiritual" (atleta 24); 
Assim, o atleta (15) assinalou a crença emocional na primeira questão, mas não forneceu dados adicionais.

Nos relatos dos atletas do Handebol sobre a crença emocional, que refletiram na alternativa "vivenciar, sentir e/ou experienciar a presença de Deus". A experiência de Deus na igreja é associada com arrepios, fortes emoções, sensação de estar protegido por algo divino e espiritual.

Sensações e sentimentos que reportam a respostas de natureza psicofisiológica que denotam a evocação da crença por estímulos no ambiente religioso, entre os quais, a atmosfera luz-cor propiciada pelos mosaicos bizantinos nas janelas das catedrais, que criam um ambiente de contemplação que reporta a própria representação de Deus, em virtude do simbolismo da luz no cristianismo, que se define pelas expressões "eu sou a luz do mundo"; "aquele que me segue não andará em trevas, mas terá a luz da vida, João 8.12" (AMUCHÁSTEGUI, 2002).

O coping emocional do estresse WEITEN, LLOYD, DUNN e HAMMER (2008), pela crença religiosa associado à atmosfera luz-cor no ambiente religioso envolve toda complexidade do fenômeno tratado na revisão de literatura deste estudo. Estímulos de natureza quântica e da mecânica da física da luz como retratados por BARLEIN (2002), MOLLON (2003); que excitam os fotorreceptores do olho humano e eliciam respostas de natureza bioelétrica e bioquímica BIRREN (1978), GEGENFURTNER e SHARPE (2002); que ativam as redes neurais LEDOUX (1998), que se associam a atividade neuropsicológica vinculada pelas condições orgânicas e pela dinâmica entre aspetos do inconsciente coletivo (arquétipo do herói), do inconsciente pessoal (sentimentos de inferioridade), o consciente, as cognições e o comportamento, vinculados pelo simbolismo da luz no cristianismo AMUCHÁSTEGUI (2002), JUNG (2008).

Ao dar continuidade a busca pela compreensão do coping do estresse no esporte pela crença emocional, conforme a representação de Deus para o atleta. A seguir são apresentados os relatos dos atletas que foram obtidos ao complementarem suas respostas por meio da reflexão na alternativa referente a crença emocional na segunda questão: 


\section{Como é Deus para você?}

$\square$ Uma pessoa. Então, o que significa para você dizer que ELE é uma pessoa?

$\square$ Aquele que dá sentido ao universo, porque o homem só pode ter sido criado por Deus. Explique?

- Uma energia. Então, como você percebe esta força e/ou energia?

$\square$ Um princípio que orienta para aquilo que é correto e aquilo que deve ser feito. Explique?

Outro ? Procure explicar detalhadamente.

\section{Relatos dos atletas:}

- "A força que se percebe, sobretudo na natureza - aquilo que Ele criou e que, também, sinto quando um homem ama o outro sem distinção de classe ou etnia" (atleta 16).

- "Um princípio que deriva de todas as coisas que existem e orientam para aquilo que é correto e deve ser feito" (atleta 19);

- "Uma energia que está presente em todos os seres vivos, que faz com que tudo viva em equilíbrio e harmonia" (20);

- "O sentimento da presença de Deus iluminando os caminhos" (atleta 21);

- "Uma energia que está presente em tudo e em todos que, geralmente, é percebida em momentos de solitude, nas expressões da natureza, nos pequenos acontecimentos e também nas dificuldades" (atleta 23).

- "Trata-se de algo como o ar, como os átomos, que não podem ser vistos, mas se sabe que estão lá" (atleta 25);

- "Porque Ele dá força e energia, basta crer e acreditar Nele" (atleta 27);

- "Quando se está mal, sentir que Ele está por perto, conversar com Ele, uma simples conversa, sentar e ficar pensando Nele - a energia entre a gente" (atleta 28);

- "A energia que move o universo e orienta as pessoas para o caminho do bem por meio de sensações" (atleta 30 ). 
O Inventário Pratt de crenças religiosas no esporte, nas questões iniciais, identifica pelas alternativas de resposta o tipo de crenças religiosas dos atletas e busca o aprofundamento das percepções por meio dos relatos. Os atletas reafirmam as proposições de PRATT $(1907,1923)$, FREITAS (2002) sobre a crença emocional. Infere-se o coping emocional pela vivência momentos obscuros e dificuldades - a busca por caminhos iluminados: "quando se está mal, sentir que Ele está por perto, conversar com Ele, uma simples conversa, sentar e ficar pensando Nele - a energia entre a gente" (atleta 28).

O aprofundamento da investigação sobre a crença emocional por meio da representação de Deus para o atleta na alternativa que reflete essa modalidade de crença na terceira questão:

\section{Você acredita em Deus? É...}

Com base em algum fato, prova ou argumento? Se for, qual (is)?

- Por que você já experimentou ou sentiu SUA presença? Descreva como foi esta experiência.

Com base na autoridade de um livro sagrado, ou de alguma pessoa? Se for, qual (is)?

Por que ele significa o agir corretamente, ter e divulgar valores morais? Explique?

Outro? Explique:

\section{Relatos dos atletas:}

- "O sentimento de acordar a cada dia, até a hora de dormir" (atleta 16);

- "O pedido de ajuda para superar dificuldades; mais fé e confiança naquilo que se estava fazendo; paz de espírito em um momento mais conturbado" (atleta 17);

- "Sentir todos os dias e todos os momentos; acreditar Nele" (atleta 21); 
- "Algo harmonioso que traz paz interior; e, faz esquecer as coisas que estão à volta" (atleta 22);

- "São os vários momentos em que me sinto protegido e abençoado por estar vivendo a experiência de cada pequeno instante" (atleta 23);

- "Sentir proteção quando se sofre um acidente - quando se vai ouvir a palavra de Deus, e, Deus fala sobre toda sua vida - também pelo testemunho de milhares de outras pessoas" (atleta 24);

-"Acreditar que existe algo superior e divino que de alguma forma todos sentem: uns mais, outros menos" (atleta 25).

Os atletas relatam energizarem-se pela percepção de Deus nos termos da crença emocional que transparece o coping emocional (WEITEN, LLOYD, DUNN e HAMMER, 2008).

A identificação do Ego, como uma fonte suprema e inesgotável de energia, ativada a partir da emoção em conexão com a percepção de estímulos internos e externos associados com a representação de Deus, que propiciam sentimentos de confiança, harmonia, paz de espírito, paz interior e força.

Para FREUD (1929 / 1930) os sentimentos religiosos é ilusão; pois só pode tornar-se fonte de energia se derivar da expressão de uma necessidade muito intensa. Entre os atletas, que identificaram suas crenças religiosas com a crença emocional, dois dos três atletas do Handebol que representaram o Brasil nas Olimpíadas de Pequim 2008, acontecimento esportivo que se caracterizou pela alta carga emotiva do comportamento dos atletas, em meio a constantes referências a Deus.

A experiência clínica mostra que a mobilização do ego pela crença emocional em torno de objetivos poucos realistas está na base de sentimentos de euforia e confiança, alternados por momentos ou a vivência crônica da depressão. Dinâmica psíquica caracterizada por somatizações, comportamentos compulsivos e, em alguns casos, a revolta contra Deus e o voltar-se contra si próprio, por meio de agressões e comportamentos autodestrutivos mediante o sentimento de ser falho indigno e não merecedor. Acontecimentos que podem marcar a passagem da crença primitiva para a atitude de desconfiança que permeia a crença intelectual. 
As FIGURAS 16, 17 e 18 demonstram que a crença intelectual foi a segunda modalidade de crença com que os atletas se identificaram $(27,78 \%)$. No IPCRE, é caracterizada como um processo dinâmico que oscila entre crença e desconfiança e distingue-se pela necessidade de comprovação, pelo apoio da crença em Deus em deduções lógicas ou conceitos intelectuais que buscam dar sentido à existência.

Os relatos obtidos dos atletas do Handebol sobre a crença intelectual que refletiram na primeira questão do Inventário Pratt de Crenças Religiosas no Esporte: O que a religião significa para você pessoalmente? É... Na alternativa: Uma crença de que algo existe? Ajudam na compreensão do coping que essa modalidade de crença possa oferecer.

Relatos dos atletas: "É a religião relativa ao meio em que a pessoa vive e foi criada" (atleta13); "A crença de que existe uma força superior, (Deus) que comanda e observa as coisas do mundo" (atleta 14); "A crença em Deus (algo superior)"(atleta 18); "É energia" (atleta 19); "A crença que todo ser humano tem uma alma, que existe uma força maior: Deus que toma conta de todos" (atleta 20); "Um ser maior que criou o universo e que intercede por todos, ajudando no dia-a-dia" (atleta 22).

O relato dos atletas sobre a crença intelectual pela representação de Deus pela religião mostra explicações de natureza intelectual "é energia". Oscilam entre a credulidade e a desconfiança, que denota menor senso de energização pela crença, menor poder de mobilização e ausência do coping emocional. Os posicionamentos dos atletas nesta questão reafirmam as proposições de PRATT (1907, 1923), FREITAS (2002), CONCEIÇÃO (2004) sobre a dúvida, sentimento de desconfiança e a busca por explicações de natureza intelectual.

A seguir, os relatos dos atletas do Handebol na segunda questão do Inventário Pratt de Crenças Religiosas no Esporte: Como é Deus para você? Na alternativa: Aquele que dá sentido ao universo, porque o homem só pode ter sido criado por Deus.

Relato dos atletas: "É Deus, o criador do universo, pois tudo tem um criador" (atleta 22); "A escritura da Bíblia. O homem foi criado semelhante a Deus. Tantas coisas inexplicáveis só podem ter o poder e a sabedoria de Deus” (atleta 24).

A crença intelectual, também é identificada na terceira questão do Inventário Pratt de Crenças Religiosas no Esporte: Você acredita em Deus? É... Na alternativa: Com base em algum fato, prova ou argumento? Se for, qual (is)? 
Relato do atleta: "Pedir, agradecer nas dificuldades e nas coisas realizadas" (atleta 18).

Em síntese, os relatos dos atletas sobre a crença intelectual deixam transparecer certa racionalização da crença, o que implicaria o coping pela avaliação cognitiva, por meio da modificação dos modos e das formas de pensamento. A busca por explicação de natureza intelectual que se afastam do objeto religioso, mas não o descarta, permitindo que possa ser utilizado como estratégia de coping em situações de grande estresse. Assim, a análise dos relatos dos atletas do Handebol sobre o coping da crença intelectual distinguiu-se do coping emocional propiciado pela crença emocional, o foco voltado para o busca de equilíbrio e harmonia que permitem a pessoa lidar melhor com os sentimentos hostis WEITEN, LLOYD, DUNN e HAMMER (2008).

As diferentes modalidades de crença destacadas nas FIGURAS 16, 17 e 18 mostram que a crença ético-moral foi assinalada sete vezes (16,67\%). Caracterizada no IPCRE, como um processo mental que está voltado à contenção de impulsos e controle do comportamento que propriamente à devoção. Os dados da crença éticomoral obtidos dos atletas do Handebol que refletiram na segunda questão do Inventário Pratt de Crenças Religiosas no Esporte: Como é Deus para você? Na alternativa: Um princípio que orienta para aquilo que é correto e aquilo que deve ser feito.

Relatos dos atletas: "Um princípio que muda de um atleta para outro. O que é certo para um, não é para outro" (atleta 13); "Alguém que nos mostra por meio de princípios e ensinamentos a maneira correta de agir" (atleta 17); "Deus é o pai de todos, assim como respeitamos as regras, normas específicas dos pais naturais, respeito e tento seguir as regras de nosso todo poderoso" (atleta que assinalou duas modalidades: intelectual e ético-moral (atleta 14).

Os dados obtidos sobre o coping da crença ético-moral dos atletas do Handebol que refletiram na terceira questão do Inventário Pratt de Crenças Religiosas no Esporte: Você acredita em Deus? É... Na alternativa: Por que ele significa o agir corretamente, ter e divulgar valores morais? 
Relatos dos atletas: "Agir corretamente nos dá tranqüilidade e paz" (atleta 13); "Pelo fato de existirem várias religiões e cada uma delas com um Deus diferente" (atleta 14); "Agir corretamente, no sentido de nunca promover nem desejar o mal a ninguém, apenas agir em favor do bem-estar de todos ao redor (atleta 20). Assim, o atleta (15) assinalou a crença ético-moral, mas não forneceu dados adicionais.

Os relatos dos atletas do Handebol sobre a crença ético-moral mostram que, apesar da natureza ambígua de algumas respostas, os atletas buscam coping para o comportamento: o agir corretamente, que poderia caracterizar uma espécie de coping com foco voltado para o problema WEITEN, LLOYD, DUNN e HAMMER, 2008. E o fortalecimento do ego (sentimento oceânico) por meio de sua identificação com valores e comportamentos idealizados FREUD (1929 / 1930).

As FIGURAS 16, 17 e 18 mostram que a crença primitiva foi assinalada pelos atletas do Handebol apenas duas vezes (5,55\%). Caracterizada no IPCRE como uma modalidade de crença que tem por base os moldes da crença original da pessoa. Caracteriza-se pelo respeito às tradições religiosas, às escrituras sagradas e figuras de autoridade secular.

Os relatos obtidos na primeira questão: $\mathbf{O}$ que a religião significa para você pessoalmente? É... Na alternativa: Respeitar as tradições e obedecer às figuras de autoridade?

Relatos dos atletas: "Foi um homem que morreu pelo próximo (atleta 18); "Foi minha formação em colégio de padres que orientava pela Bíblia, mas não de forma radical ou imposta, que me orientou ter minha própria opinião e formar meus conceitos (atleta 19).

Os dados obtidos sobre a crença primitiva denotam que o coping oferecido por esta modalidade de crença tem por base os mesmos modelos do pensamento na crença original do atleta, diante das mudanças impostas pela vida.

A alternativa referente a outro significado foi assinalada apenas uma vez $(2,78 \%)$ : acredito em Deus porque fui criado por pais católicos, porque ia à igreja aos domingos. Além disso, acredito que sinto a energia, pois quando rezo ou peço algo Ele me dá força para que seja realizado. 
A análise desse relato evidencia que, apesar do atleta ter atribuído outra significação à sua crença, a resposta pode ser associada à crença primitiva, pois o atleta afirmou que acredita que sente a energia. Posicionamento que diferente da intensidade no discurso dos atletas que associaram suas crenças ao emocional e firmam que efetivamente vivenciam e sentem Deus cenestésica e sinestesicamente.

\subsubsection{O coping pela crença da interferência de Deus como ajuda para superar obstáculos no esporte e a freqüência dos sintomas de estresse dos atletas do handebol pela LSS-VAS}

Dando seqüência ao modelo de análise, que busca esclarecer as hipóteses sobre o coping propiciado pelas crenças religiosas, a seguir, são apresentados e analisados os dados obtidos na questão do IPCRE: Você acredita que Deus poderia ajudar a vencer obstáculos no esporte? Seis atletas (50\%) assinalaram: não; quatro atletas (33\%) assinalaram: sim; e dois atletas (17\%) assinalaram, às vezes.

A análise pelo coeficiente de Pearson mostrou uma correlação significativa $(p=0,009)$ entre o posicionamento dos atletas do Handebol nesta questão e a freqüência dos 23 primeiros itens da LSS-VAS que apresentaram correlações mais fortes:

LSS-VAS "Fico esgotado (a) emocionalmente" $(\mathbf{p}=\mathbf{0 , 0 3 2})$. Os atletas que assinalaram sim ou às vezes: acreditam que Deus pode ajudar a vencer obstáculos no esporte, associaram-se àqueles que assinalaram que, com maior freqüência, ficam esgotados. Já os que assinalaram que não acreditar que Deus pode ajudar a vencer obstáculos no esporte aos que nunca ficam esgotados.

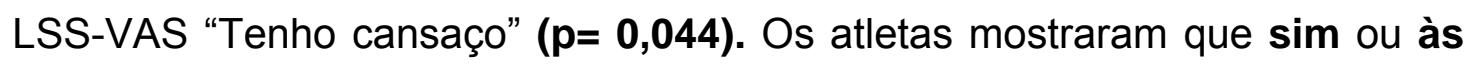
vezes: acreditam que Deus pode ajudar a vencer obstáculos no esporte, associaram-se àqueles que assinalaram, com maior freqüência, sentem cansaço. Já os que assinalaram que não acreditar que Deus pode ajudar a vencer obstáculos no esporte, associaram-se aos que assinalaram nunca sentir cansaço.

Os atletas que assinalaram: sim, acreditam que Deus pode ajudar a superar obstáculos no esporte, complementaram o posicionamento com os seguintes dados: Ele pode nos ajudar a encontrar respostas e caminhos que, às vezes, não 
encontramos sozinhos. Além de motivar nos momentos em que não estamos tão felizes (17); por causa dessa energia presente, mas, partindo do princípio. Neste caso, da força de dentro para fora (19); Acredito que Deus dá equilíbrio, auxilia o atleta, dando força e esperança para que nunca desista e enfrente os obstáculos (20); Não ajuda diretamente, como fazer o pedido de ganhar um campeonato, mas no sentido de que você enfrente e continue no dia-a-dia treinando e seguindo, ultrapassando obstáculos (23).

Os atletas que assinalaram: às vezes, complementaram este posicionamento com as seguintes informações: acho que Ele pode te ajudar estimulando nos treinamentos para dar mais força e coragem (21). O outro atleta não forneceu mais dados sobre seu posicionamento (15).

Os atletas que não acreditam que Deus pode ajuda a vencer obstáculos no esporte complementaram com os seguintes dados: tudo depende de talento, trabalho e dedicação, quando o assunto é esporte competitivo (13); Ele te dá condição de estar bem equilibrado para 0 treinamento e a competição, conseqüentemente, as vitórias (14); No esporte, acho mais que se você treinar mais que o outro, consegue obter mais objetivos positivos - acho que ajuda na hora de uma lesão (16); A coisa que peço é para não me machucar. O resto somos nós que fazemos (18); Acho que diretamente não. É uma influência que pode ajudar (22); Acredito que Deus gostaria que todos obtivessem a vitória e não só um com alegria e o outro com tristeza. Acredito que seja nossa profissão e se trabalharmos muito, obteremos nosso resultado, pois Deus deixou para o homem que recebesse o fruto de seu trabalho - isso é uma bênção! (24).

Os dados obtidos até este ponto mostram um paradoxo no esporte: os atletas que afirmaram não acreditar que Deus possa ajudar a vencer obstáculos no esporte, apresentaram menores escores de sintomas de estresse, inferindo-se aquilo que WEITEN, LLOYD, DUNN e HAMMER (2008) definem como coping pelo foco no problema, ser mais eficiente para enfrentar dificuldades no esporte, como foi demonstrado pelos relatos: tudo depende de talento, trabalho e dedicação quando o assunto é esporte competitivo. Se você treinar mais que os outros, vai conseguir mais objetivos positivos; se trabalharmos muito, o resultado será obtido. 
Neste processo, a dúvida mostrou-se associada aos maiores escores de freqüências de sintomas de estresse. $E$ menor freqüência nos atletas que descartaram a possibilidade de Deus ajudar a vencer obstáculos no esporte, entre os quais dois dos três atletas que participaram das Olimpíadas de Pequim 2008.

Estes dados permitem inferir preliminarmente que a busca pela ajuda de Deus, como coping não é garantia de eficácia. Pelo contrário, a busca denota a vivência de momentos obscuros, incertezas, dificuldades e desânimo que se agravam frente à inexistência de serviços de apoio psicológico aos atletas e caracterizam um cenário em que Deus surge como a única saída aos atletas.

\subsubsection{Características do coping pelo hábito dos atletas rezarem nas competições esportivas e a freqüência dos sintomas de estresse dos atletas do handebol pela LSS-VAS}

$\mathrm{Na}$ questão do IPCRE - Você reza para obter a vitória nas competições esportivas: sete atletas $(58,3 \%)$ assinalaram: não; dois $(16,7 \%)$, às vezes; e, três $(25 \%)$, sim. Revelaram as seguintes propensões ao coping por meio de seus posicionamentos sobre a questão:

- Atletas que assinalaram: sim, rezam para obter a vitória nas competições esportivas: peço para que Deus nos ajude a jogar bem e que nós possamos fazer um bom jogo (17). Nesse caso, rezar não é o Pai Nosso ou a Ave Maria. De certa forma, peço força... para encontrar as respostas dentro de mim. (19); rezo em busca de proteção para não me machucar nem os outros jogadores dos dois times, e para que eu tenha condições de dar o máximo no jogo (20).

- Atletas que assinalaram: às vezes, rezam para obter a vitória nas competições esportivas: rezo para pedir proteção para todos sobre lesão e agradecer por mais um jogo (21). O outro atleta não forneceu mais dados sobre seu posicionamento (15).

- Atletas que assinalaram: não, rezam para obter a vitória nas competições esportivas: tenho um momento de reflexão antes do jogo, mas não pedindo a vitória (13); rezo para que me dê saúde (14); eu peço proteção para todos os atletas (21); rezo para que interceda e tudo corra bem na quadra (22); não acho que meus 
momentos de reflexão sirvam para outros tipos de aprendizado e para obter outro tipo de coisas (23); rezo por proteção (24).

A análise pelo coeficiente de Spearman apresentou correlação $(p=0,015)$ entre a questão IPCRE: Você reza para obter a vitória nas competições esportivas? E o somatório de freqüência do total dos itens da LSS-VAS que apresentou correlações mais acentuadas foram:

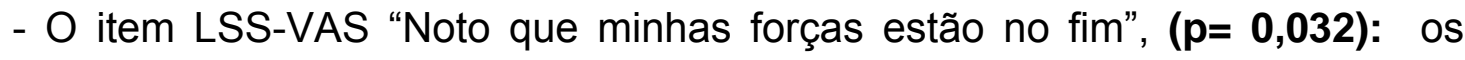
atletas que assinalaram: sim, rezam para obter a vitória nas competições esportivas, associaram-se aos que, com maior freqüência, sentem que suas forças estão no fim. $E$ os que assinalaram não aos que mostraram nunca sentiram que suas forças estavam no fim.

- O item LSS-VAS: "Tenho cansaço", ( $p=0,013)$. Os atletas que mostraram: sim, rezam para obter a vitória nas competições esportivas, associaram-se aos atletas que assinalaram sentir cansaço com maior freqüência. $E$ os que não rezam para obter a vitória, aos que mostraram nunca sentir cansaço.

- O item LSS-VAS: "Não tenho vontade de fazer as coisas", $(p=0,042)$ : os atletas que assinalaram: sim, rezam para obter a vitória nas competições esportivas, associaram-se aos que, com maior freqüência, não têm vontade de fazer as coisas. Os que assinalaram não, aos que nunca sentem falta de vontade de fazer as coisas.

- O item LSS-VAS: "Ouço zumbidos nos ouvidos", $(p=0,005)$ : os atletas que assinalaram: às vezes, rezam para obter a vitória nas competições esportivas, associaram-se aos que, com maior freqüência, ouvem zumbidos nos ouvidos. Próximo a estes, ficaram os atletas que assinalaram: sim. Os atletas que assinalaram: não, rezam para obter a vitória nas competições esportivas aos que nunca ouvem zumbidos nos ouvidos, conforme a demonstração pela curva dos dados destacados pela FIGURA 19 


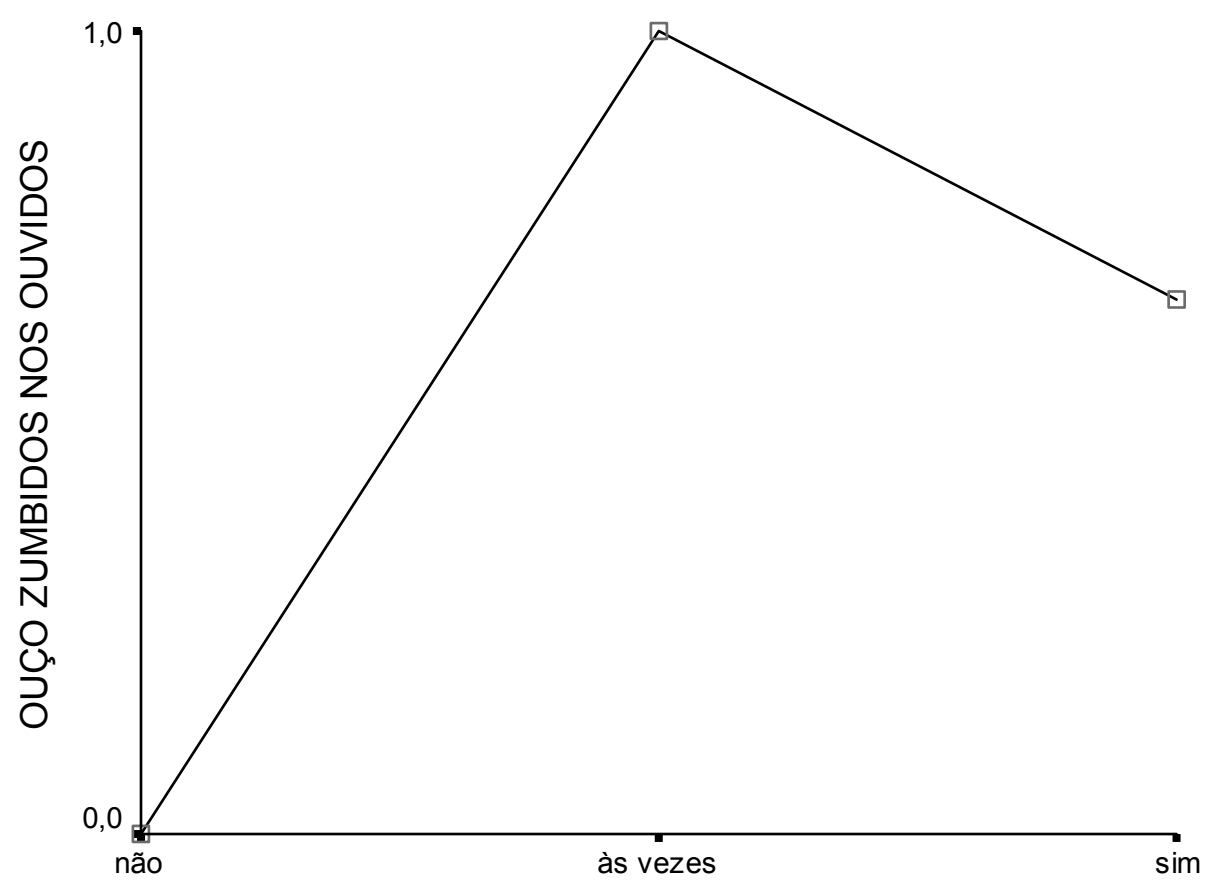

Você reza para obter a vitória nas competições esportivas?

FIGURA 19 - Associação entre a sensação de zumbidos nos ouvidos e o hábito de rezar para obter a vitória dos atletas do Handebol de alto rendimento

Estruturalmente, a FIGURA 19, construída com base na representação dos valores médios obtidos, mostra a dúvida e o habito de rezar associados com 0 estresse. Os atletas que assinalaram: sim e às vezes, rezam para obter a vitória nas competições esportivas, mostraram que ouvem zumbidos nos ouvidos, os quais se constituem como estímulos estressores e sintoma de estresse. Neste contexto, o habito de rezar obter vitórias, revelou-se como coping pouco eficiente ao estresse.

O item LSS-VAS: "Sinto exaustão física" $(p=\mathbf{0 , 0 4 8})$. Os atletas que assinalaram que: às vezes, rezavam para obter a vitória nas competições esportivas, associaram-se aos que, com maior freqüência, sentiam exaustão física. Próximo a estes, ficaram os atletas que assinalaram: sim. Os atletas que assinalaram que não rezavam para obter a vitória nas competições esportivas associaram-se aos que nunca sentiam exaustão física. 
O item LSS-VAS: "Sinto insatisfação com meu trabalho" $(p=0,049)$. Os atletas que assinalaram que: sim e às vezes, rezavam para obter a vitória nas competições esportivas, associaram-se aos que, com maior freqüência, sentiam insatisfação com o trabalho, e os atletas que assinalaram que não rezavam associaram-se aos que nunca sentiam insatisfação.

O item LSS-VAS: "Tenho dúvidas sobre mim mesmo $(a)$ " $(p=0,009)$. Os atletas que assinalaram que: sim e às vezes, rezavam para obter a vitória nas competições esportivas, associaram-se aos que, com maior freqüência, tinham dúvidas sobre si próprios, os que assinalaram que não rezavam, aos que nunca tinham dúvidas sobre si próprios.

O item LSS-VAS: "Meus músculos estão sempre tensos" $(p=\mathbf{0 , 0 4 2})$. Os atletas que assinalaram que: sim e às vezes, rezavam para obter a vitória nas competições esportivas, associaram-se aos que, com maior freqüência, tinham os músculos tensos, os que assinalaram que não rezavam aos que nunca tinham tensão muscular.

O item LSS-VAS: "Tenho vontade de largar tudo o que estou fazendo" ( $p=$ $\mathbf{0}, \mathbf{0 1 8}$ ). Os atletas que assinalaram que: às vezes, rezavam para obter a vitória nas competições esportivas, associaram-se aos que, com maior freqüência, tinham vontade de largar tudo. Já os atletas que assinalaram não, aos que nunca tinham vontade de abandonar o esporte. Observou-se que os atletas que afirmaram: sim, ficaram em uma posição intermediária nessa questão.

O item LSS-VAS: "Tenho discutido freqüentemente com amigos e familiares" $(p=0,020)$. Os atletas que assinalaram que: sim, rezavam para obter a vitória nas competições esportivas, associaram-se aos que, com maior freqüência, tinham discussões com amigos e familiares, e os que assinalaram que não rezavam aos que nunca tinham discussões com amigos e familiares.

Os dados obtidos até este ponto permitem inferir que houve correlação entre sintomas de estresse e a busca pela ajuda de Deus para superar obstáculos no esporte, entretanto o coping oferecido pelas crenças religiosas não é garantia de efetividade; pelo contrário, os atletas buscam ajuda divina quando estão vivenciando situações criticas no esporte. 


\subsection{Apresentação e discussão dos dados dos atletas de Voleibol}

Os dados dos atletas do Voleibol que integraram o projeto-piloto, cuja análise foi aprofundada no contexto do estudo global. As correlações entre as variáveis numéricas pelo teste de Pearson foram substituídas pelo teste de Spearman, por ser este mais apropriado ao estudo. A amostra constituiu-se por 12 atletas que ingressavam no clube: quatro pontas, dois levantadores, dois meio de quadra, dois líberos e dois opostos; oriundos de diferentes classes sociais e estados da federação brasileira; do sexo masculino; com média de idade 18,67 (mínimo 18 e máximo 20 anos); nível de escolaridade: três de nível superior incompleto (cursando educação física), oito de nível médio e um com nível de primeiro grau; quanto à confissão religiosa: quatro católicos, dois protestantes, dois evangélicos, quatro não declararam a religião. No entanto, todos os atletas pesquisados mostraram que acreditam em Deus, cujos dados reafirmam a idéia na qual se embasou PRATT, sobre a representação de Deus, como base para se pesquisar as dimensões envolvidas nas crenças religiosas.

\subsubsection{Caracterização das condições da coleta de dados do Voleibol}

Os dados dos atletas do Voleibol foram coletados no período da tarde, em uma quadra coberta, antes e depois de um jogo na instituição pesquisada, entre os próprios sujeitos da pesquisa, na qual o pesquisador inseriu-se no programa normal de treinando dos atletas.

A principal característica revelou-se pela uniformidade da amostra, como resultante da seleção prévia a que são submetidos os atletas, isto refletiu na padronização da experiência. Assim, 91,7\% dos colaboradores estavam em média três meses no clube, apenas um atleta estava no clube há 14 meses. Dados que poderiam caracterizar a situação dos atletas do Voleibol no contexto clássico da Síndrome Geral de Adaptação ao estresse (SAG), como fase de alarme.

Os atletas vinham de localidades completamente diversas: um do Estado de Goiás, dois de Minas Gerais, três do Paraná, um do Rio Grande do Sul, três de 
Santa Catarina e dois de São Paulo (um do interior e o outro da capital). Além das exigências implícitas para mostrar desempenho e enquadrar-se nas normas da instituição para garantir a permanência no clube, tinham de ajustar-se ao convívio de uns com os outros. As hipóteses do presente estudo implicam sintomas de estresse e variações da cor da pele, "amarelão", mediadas pelo coping das crenças religiosas e lócus de controle dos atletas.

\subsubsection{Principais resultados obtidos sobre a oscilação da cor da pele dos atletas Voleibol pré e pós-treinos pelo método espectrofotométrico}

Com o objetivo de esclarecer as hipóteses, são analisados os principais dados obtidos pela mensuração da cor da pele na parte interna do braço e no rosto dos atletas do Voleibol, relativos aos valores $L^{*} a^{*} b^{*}$ e seus respectivos deltas pré e pós-treinos ; valores mínimos, máximos, média e desvio-padrão destacados na TABELA 6. 
TABELA 6 - Valores mínimos, máximos, médias e desvio-padrão da oscilação $\underline{\text { espectral } L^{*} a^{*} b^{*} \underline{27}}$ no braço e no rosto de atletas de Voleibol

\begin{tabular}{lrrrrr}
\hline \hline & $\mathrm{N}$ & Mínimo & Máximo & Média & $\begin{array}{r}\text { Desvio } \\
\text { padrão }\end{array}$ \\
\hline L (braço) & 10 & 52,90 & 69,29 & 60,6940 & 5,1187 \\
L (rosto) & 10 & 47,41 & 61,16 & 55,8350 & 4,7469 \\
DL (braço) & 10 & $-1,47$ &, 92 & $4,00 \mathrm{E}-03$ &, 7764 \\
DL (rosto) & 10 & $-2,95$ &, 92 & $-1,5110$ & 1,1581 \\
a* (braço) & 10 & 7,84 & 12,15 & 9,6340 & 1,5603 \\
a* (rosto) & 10 & 12,81 & 25,05 & 16,6690 & 3,7420 \\
Da* (braço) & 10 & $-1,45$ & 2,94 &, 2270 & 1,3231 \\
Da* (rosto) & 10 &,- 62 & 2,44 &, 6670 & 1,0387 \\
b* (braço) & 10 & 12,33 & 21,00 & 17,6070 & 3,1460 \\
b* (rosto) & 10 & 14,89 & 21,01 & 17,4130 & 2,2032 \\
Db* (braço) & 10 & $-1,51$ & 1,14 &,- 4140 &, 9325 \\
Db* (rosto) & 10 & $-2,21$ &, 84 & $-1,2880$ & 1,0551 \\
casos válidos & 10 & & & & \\
\hline \hline
\end{tabular}

${ }^{27}$ CIE $L^{*} a^{*} b^{*}$ - unidades de medida de cor proposto pelo Commission Internationale de E'clairege com base na teoria de absorção e reflexão da luz, ver FIGURA 5, p. 42: L* (claro-escuro); a* (vermelho-verde); b* (azulamarelo).

L* - o valor zero corresponde à absorção máxima da luz (preto) e valor 100 à reflexão máxima (branco) $\mathrm{a}^{*}$ - os valores negativos ( zero à -50) correspondem ao verde; e os valores positivos ( zero à 50) ao vermelho $b^{*}$ - os valores negativos ( zero à -50) correspondem ao azul e os valores positivos ( zero à 50) ao amarelo 
Os dados apresentados na TABELA 6 demonstram que as variações da cor da pele dos atletas do Voleibol $\left(\mathrm{DL}^{*}, \mathrm{Da}^{*} \text { e } \mathrm{Db}^{*}\right)^{28}$ oscilaram de modo uniforme, entre valores positivos e negativos no braço e no rosto nas medições realizadas antes e depois do jogo. Em razão das dificuldades na mensuração pós-treino, duas medições perderam-se (o pesquisador não teve acesso aos dados faltantes), por isso, foram apresentados apenas dez casos da mensuração da cor da pele dos atletas de voleibol.

\subsubsection{Principais resultados obtidos sobre a freqüência e intensidade de sintomas de estresse dos atletas do Voleibol por meio da Lista de Sintomas de Stress (LSS-VAS)}

Os valores das freqüências dos sintomas de estresse dos atletas do Voleibol foram obtidos pela aplicação dos 23 primeiros itens dos sintomas de estresse da Lista de Sintomas de Stress LSS-VAS, para criar um modelo que possibilitasse a comparação entre os dados da aplicação da lista completa dos outros atletas. Os valores obtidos foram classificados em quartis, conforme a distribuição proposta pelo Prof. Dr. Esdras Guerreiro Vasconcellos ${ }^{29}$, sobre o valor correspondente à baixa intensidade de sintomas de estresse na população (13\%). Assim, o primeiro quartil compreendeu valores iguais ou inferiores a 17, o que denotam baixa freqüência de sintomas de estresse. O segundo quartil compreendeu valores de 18 a 34 , mostram média freqüência dos sintomas de estresse. O terceiro quartil, valores de 25 a 51 , alta freqüência e o quarto quartil, valores entre 52 e 69, altíssima freqüência dos sintomas de estresse. Os dados sobre a freqüência de sintomas de estresse dos atletas do Voleibol são destacados na TABELA 7.

\footnotetext{
${ }^{28}$ Os valores de delta: $\mathrm{DL}^{*}, \mathrm{Da}^{*}, \mathrm{Db}^{*}$ das diferenças das oscilações da cor da pele foram calculados subtraindose os valores obtidos nas medições pós-treino das medições pré-treino. Calculados por meio do programa de processamento de dados espectrais que acompanha o equipamento Espectro Colorimetro Minolta CR 410.

${ }^{29}$ Comunicação pessoal
} 
TABELA 7- Freqüência dos sintomas de estresse dos atletas do Voleibol por meio da Lista de Sintomas de Stress LSS-VAS

\begin{tabular}{|c|c|c|c|c|}
\hline & & & & $\begin{array}{r}\text { LSS - VAS } \\
\text { (Freqüência } 23 \text { ítens) }\end{array}$ \\
\hline \multirow{33}{*}{$\begin{array}{l}\text { TEMPO DE } \\
\text { PERMANÊNCIA }\end{array}$} & UM MÊS & 1 & & 13,00 \\
\hline & & 2 & & 17,00 \\
\hline & & 3 & & 25,00 \\
\hline & & 4 & & 15,00 \\
\hline & & Total & $\mathrm{N}$ & 4 \\
\hline & & & Média & 17,5000 \\
\hline & & & Mínimo & 13,00 \\
\hline & & & Máximo & 25,00 \\
\hline & & & Desvio-padrão & 5,2599 \\
\hline & DOIS MESES & 1 & & 9,00 \\
\hline & & 2 & & 21,00 \\
\hline & & 3 & & 10,00 \\
\hline & & 4 & & 27,00 \\
\hline & & Total & $N$ & 4 \\
\hline & & & Média & 16,7500 \\
\hline & & & Mínimo & 9,00 \\
\hline & & & Máximo & 27,00 \\
\hline & & & Desvio-padrão & 8,7321 \\
\hline & TRÊS & 1 & & 28,00 \\
\hline & MESES & 2 & & 10,00 \\
\hline & & 3 & & 8,00 \\
\hline & & Total & $N$ & 3 \\
\hline & & & Média & 15,3333 \\
\hline & & & Mínimo & 8,00 \\
\hline & & & Máximo & 28,00 \\
\hline & & & Desvio-padrão & 11,0151 \\
\hline & 14 MESES & 1 & & 22,00 \\
\hline & & Total & $N$ & 1 \\
\hline & TOTAL & $\mathrm{N}$ & & 12 \\
\hline & & Média & & 17,0833 \\
\hline & & Mínimo & & 8,00 \\
\hline & & Máximo & & 28,00 \\
\hline & & Desvio-padrão & & 7,3170 \\
\hline
\end{tabular}

Fonte: arquivo do pesquisador 
A TABELA 7 demonstra que sete (58 \%) dos 12 atletas do Voleibol ingressantes no esporte de alto rendimento apresentaram baixa freqüência de sintomas de estresse (primeiro quartil) e cinco (42\%) média freqüência de sintomas de estresse (segundo quartil).

A distribuição dos resultados entre baixa e média freqüência foi uniforme em relação ao tempo na instituição. O atleta que estava há mais tempo (14 meses), apresentou nível médio de freqüência de sintomas de estresse. Os sintomas de estresse que foram assinalados com maior freqüência pelos atletas de Voleibol, foram: "no fim de um dia de trabalho estou esgotado" (média =1,75); "Como demais" ( édia $=1,67$ ); "Tenho pensamentos que me deixam ansioso (média $=1,42$ ) "rôo unhas" (média = 1,33); "Sinto dores nas costas" (média = 1,33); "Tenho cansaço" ( édia =1,17); e "quando me levanto de manhã, já estou cansado" (média =1,08). Sintomas de estresse que denotam ansiedade e a intensificação dos treinos no esporte de alto rendimento.

\subsubsection{Análise da associação entre freqüência de sintomas de estresse e a oscilação da cor da pele no rosto e braço dos atletas do Voleibol}

A análise pelo coeficiente de correlações Spearman dos dados obtidos sobre a freqüência dos 23 primeiros itens de sintomas de estresse LSS-VAS, e os deltas das diferenças de cor da pele em medições no braço e no rosto por meio dos valores espectrais $\mathrm{DL}^{*}$ (claro-escuro), Da* (vermelho-verde) e Db* (azul-amarelo); mostrou: $\mathrm{DL}^{*}$ (braço, $p=0,293$; rosto $p=0,907$ ); $\mathrm{Da}^{*}$ (braço, $p=0,987$; rosto $p=0,533$ ), e $\mathrm{Db}^{*}$ (braço $p=0,138$; rosto $p=0,751$ ).

Pelos resultados, não houve correlação significativa entre o somatório da freqüência parcial dos itens de sintomas de estresse da LSS-VAS e as variações da cor da pele $\mathrm{DL}^{*}$, Da* e $\mathrm{Db}^{*}$ (braço e rosto). Entretanto, verificou-se associação entre a freqüência de estresse e os itens parciais da LSS-VAS, pela análise do coeficiente de Spearman, houve correlação significativa entre a oscilação da cor da pele $\mathrm{Db}^{*}$ (azul-Amarelo) e os itens: "Qualquer coisa me apavora" ( $\mathbf{p}=\mathbf{0 , 0 0 7 )}$ e "Tenho medo" ( $p=\mathbf{0}, \mathbf{0 0 1})$, conforme a curva construída com base nos valores médios dos dados obtidos, que são destacados pelas FIGURAS 20 e 21. 


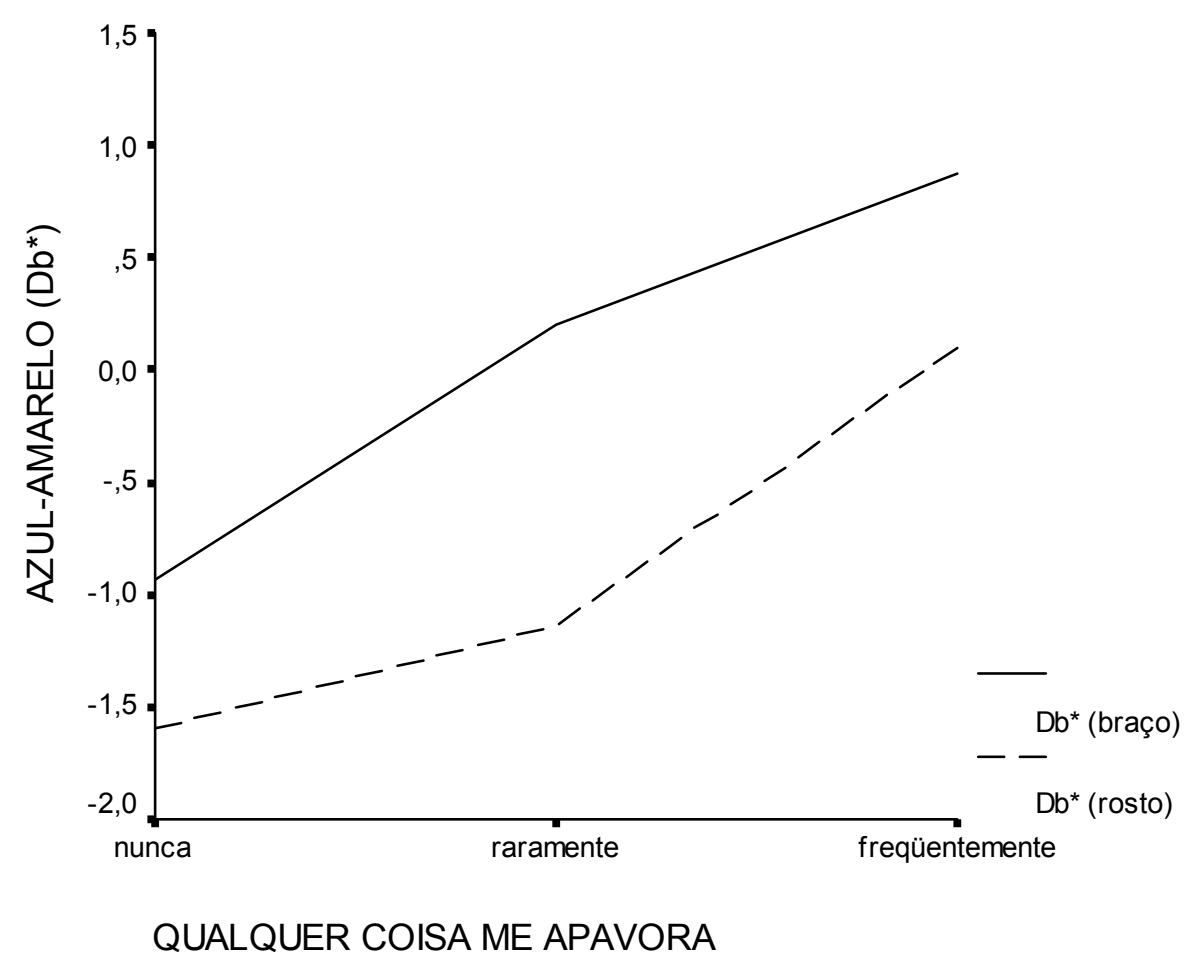

FIGURA 20 - Associação do sentimento de pavor e a oscilação espectral Db* (azulamarelo) do braço e no rosto dos atletas do Voleibol

A FIGURA 20 mostra que a oscilação da cor da pele $\mathrm{Db}^{*}$ (azul-amarelo) e o sentimento de pavor entre os atletas ingressantes no esporte de alto rendimento revelou a mesma tendência de oscilação nas medições do braço e rosto. Entretanto, foi significativa apenas nas medições do braço $(p=0,007)$. Estes resultados colocam em perspectiva os atletas que assinalaram nunca sentir pavor, apresentaram a cor da pele significativamente menos amarelada depois do jogo, em relação aos que mostraram que ficam apavorados.

A análise pelo coeficiente de Spearman, também, revelou uma correlação significativa entre a oscilação da cor da pele $\mathrm{Db}^{*}$ (azul-Amarelo) e o item "Tenho medo" ( $p=0,001)$, que é mostrada pela curva dos valores médios, destacados pela FIGURA 21. 


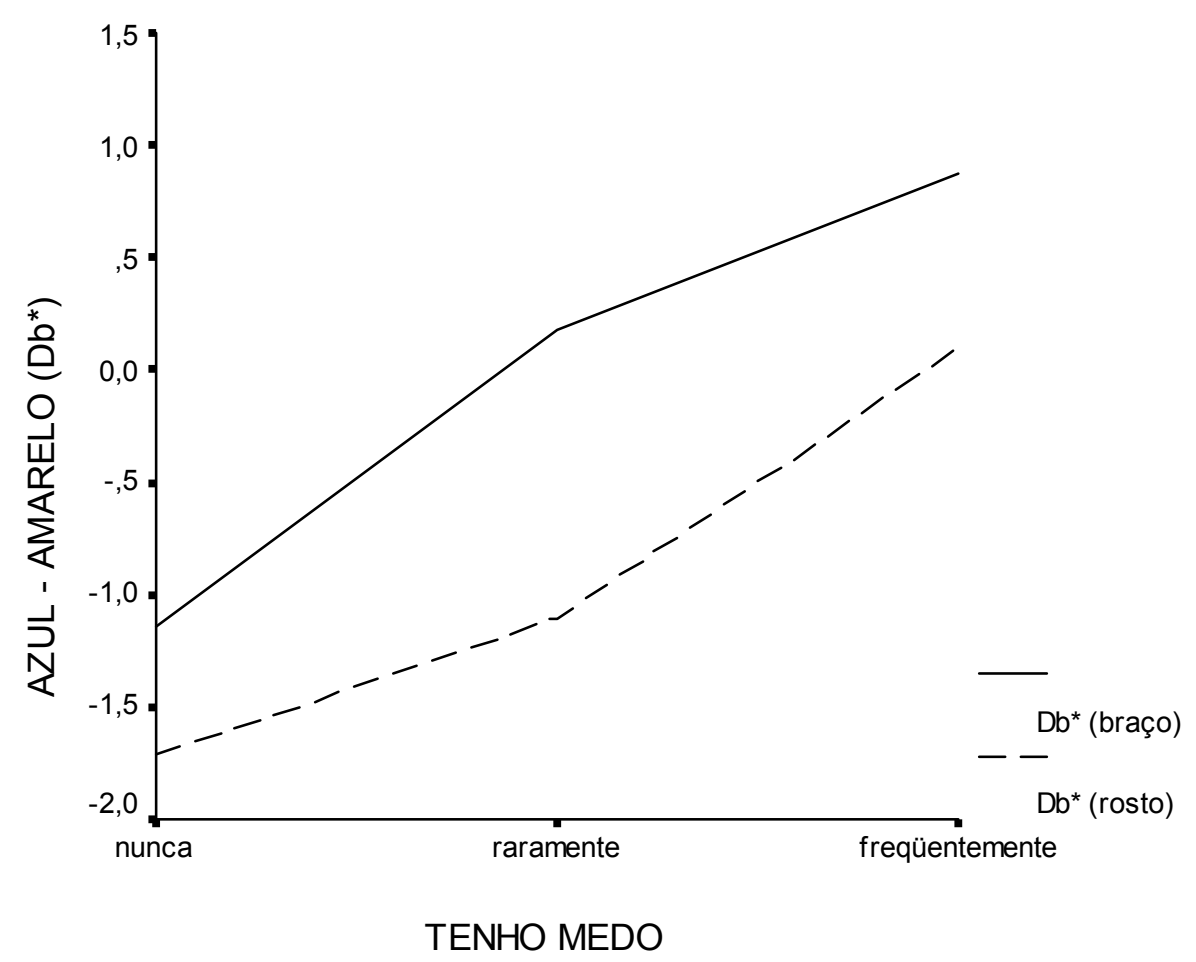

FIGURA 21 - Associação do sentimento de medo e a oscilação espectral Db* (azulamarelo) do braço e no rosto dos atletas do Voleibol

A FIGURA 21 mostra que a oscilação da cor da pele $\mathrm{Db}^{*}$ (azul-amarelo) e o sentimento de medo entre os atletas ingressantes no esporte de alto rendimento revelou a mesma tendência de oscilação nas medições do braço e rosto. Entretanto, foi significativa apenas nas medições do braço $(\mathbf{p}=\mathbf{0 , 0 0 1 )}$. Estes resultados colocam em perspectiva os atletas que assinalaram nunca sentir medo, apresentaram a cor da pele significativamente menos amarelada depois do jogo, em relação aos que mostraram que sentem medo.

A análise pelo coeficiente de Spearman da associação entre as freqüências dos 23 primeiros itens da LSS-VAS mostrou correlação significativa com o item 17 "sinto angústia", a oscilação da cor da pele DL*(claro-escuro: medição do braço, $\mathrm{p}=0,013$ ) e a oscilação da cor da pele $\mathrm{Db}^{*}$ (azul-amarelo: medição no rosto, $p=0,038$ ); cujos dados oscilaram, conforme a curva construída com base nos valores médios, destacados pela FIGURA 22. 


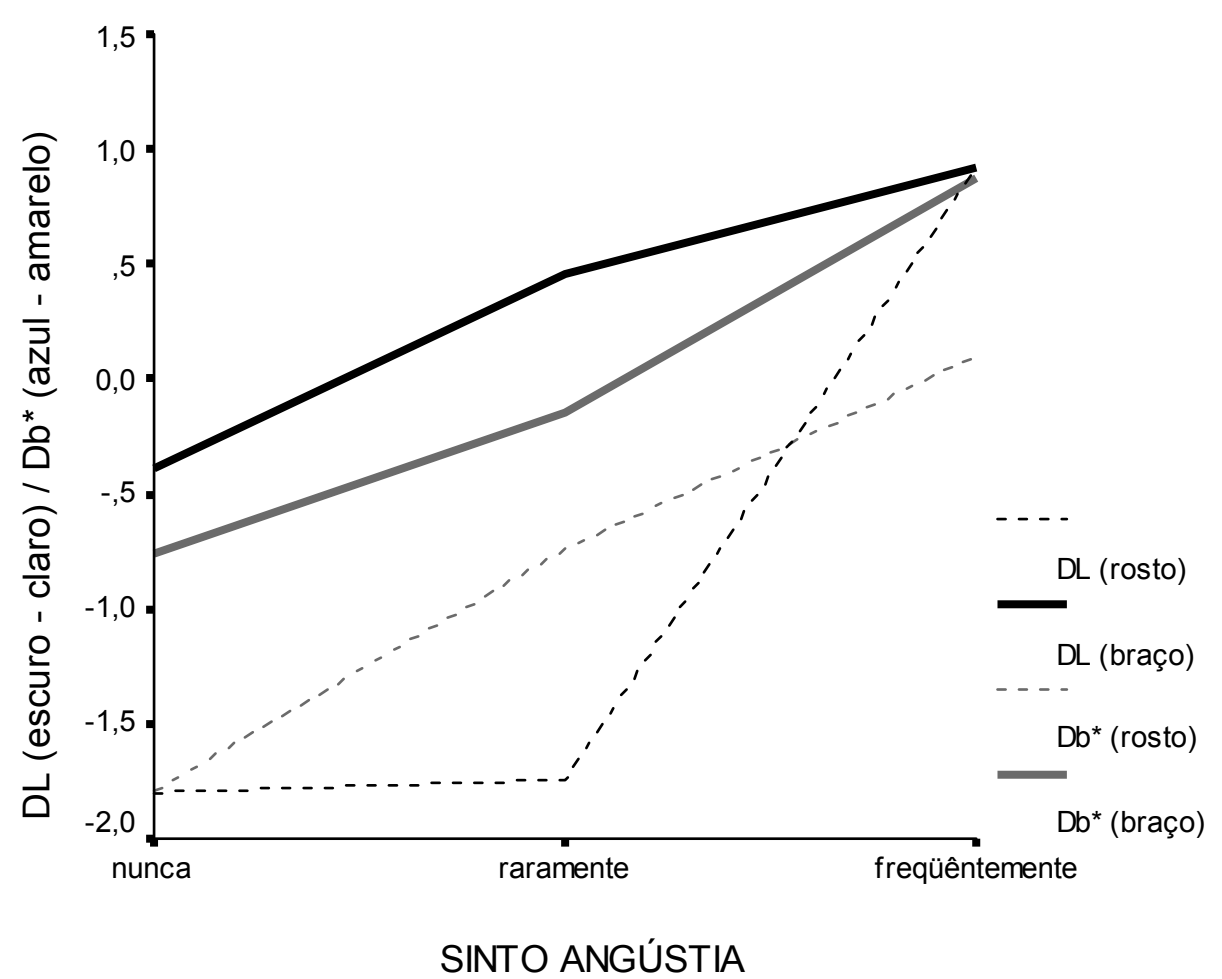

FIGURA 22 - Sentimento de angústia e oscilaccão espectral DL (claro-escuro), Db* (azul-amarelo) do braço e no rosto dos atletas do Voleibol

A FIGURA 22 demonstra que a oscilação da cor da pele DL*(claro-escuro) no braço e $\mathrm{Db}^{*}$ (azul amarelo) no rosto revelou as mesmas tendências de oscilação, em relação ao sentimento de angústia dos atletas do Voleibol ingressantes no esporte de alto desempenho. Coloca em perspectiva o fato dos atletas revelarem freqüentemente sentir angústia, assim apresentaram a cor da pele significativamente mais amarelada e mais clara depois do jogo, em relação aos que afirmaram sentir angústia com menos freqüência.

As oscilações da cor da pele devem ser contextualizadas pela realidade das equipes esportivas, foi notável o fato de que o atleta do Voleibol que ingressava no esporte de alto rendimento - tempo médio de permanência na instituição: três meses. Percebesse a situação de pesquisa, além das proposições do estudo, a própria possibilidade de permanência na instituição. Assim, o momento vivido pelos 
atletas do Voleibol, caracterizou-se pelo "amarelão" depois do treino, associado com a freqüência dos sintomas do estresse: angústia, pavor e medo, como sintomas característicos da situação de alarme nos termos referidos por NITSCH, ALLMER, HACKFORT, LAZARUS, MCGRATH, SELYE e UDRIS (1981).

BECKER (2007) observa que a angústia está relacionada com uma das características mais marcantes de nossa cultura, o impulso ao heroísmo e a necessidade de ser reconhecido. O domínio pelo arquétipo do herói, conforme referido na revisão de literatura deste estudo DURAND (1998), CONCEIÇÃO (2004), CAMPBELL (2007), JUNG (2008).

A angústia gerada pelo impulso ao heroísmo (ser reconhecido pelo esporte) e a constatação da falta de controle sobre a carreira esportiva, situação em que o verdadeiro foco de pavor não é a angústia, mas o medo do julgamento que o atleta vê-se submetido diante de sua autoconsciência, ou seja, o conhecimento que ele tem de suas limitações, frente ao sistema de exclusão que caracteriza o esporte de alto rendimento. Neste contexto, o medo da queda, possui implicações reais, o medo de acidentes no esporte. E implicações simbólicas que reportam ao mito bíblico da queda e a perda do paraíso, que simboliza a consciência das limitações do se humano e a finitude da vida.

\subsubsection{Expectativas do lócus de controle dos atletas do Voleibol por meio da Escala Multidimensional de Lócus de Controle do esporte (EMLCE)}

Dando continuidade à busca por esclarecimento das hipóteses de pesquisa, a partir deste ponto são apresentados os dados obtidos pela aplicação da Escala Multidimensional de Lócus de Controle do Esporte (EMLCE) aos atletas de Voleibol. Conforme a estatística descritiva das expectativas do lócus de controle: os valores mínimos, máximos, médias e desvios-padrão são apresentados nos dados da TABELA 8. 
TABELA 8 - Expectativas do lócus de controle dos atletas do Voleibol ingressantes no esporte de alto rendimento

\begin{tabular}{|c|c|c|c|c|c|}
\hline & $\mathrm{N}$ & MÍNIMO & MÁXIMO & MÉDIA & $\begin{array}{r}\text { DESVIO } \\
\text { PADRÃO }\end{array}$ \\
\hline $\begin{array}{l}\text { LÓCUS DE CONTROLE INTERNO - } \\
\text { LCI }\end{array}$ & 12 & 26 & 41 & 34,25 & 5,40 \\
\hline $\begin{array}{l}\text { LÓCUS DE CONTROLE EXTERNO } \\
\text { SORTE-AZAR - LCE-SA }\end{array}$ & 12 & 8 & 27 & 20,33 & 5,55 \\
\hline $\begin{array}{l}\text { LÓCUS DE CONTROLE EXTERNO } \\
\text { PESSOAS PODEROSAS - LCE-PP }\end{array}$ & 12 & 12 & 33 & 19,75 & 6,73 \\
\hline casos válidos & 12 & & & & \\
\hline
\end{tabular}

A TABELA 8 mostra os dados sobre lócus de controle obtidos dos atletas do Voleibol: lócus de controle interno $\operatorname{LCl}$ 34,25 (média alta de lócus de controle interno); lócus de controle externo sorte-azar LCE-AS 20,33 (média baixa de lócus de controle externo sorte azar); e lócus de controle externo pessoas poderosas LCEPP 19,75 (média baixa de lócus de controle externo pessoas poderosas). Esses valores aproximam-se dos dados obtidos pelos atletas do Handebol, tanto na construção da escala de Lócus de Controle como dos dados obtidos neste estudo. Houve reprodutibilidade dos escores do lócus de controle e confirma a tendência de média alta de escores de lócus de controle no esporte de alto desempenho.

A investigação das três subescalas de Lócus de Controle do Esporte (EMLCE), também, mostrou pela análise do coeficiente de Pearson correlação significativa $(p=0,034)$ entre o lócus de controle externo sorte-azar e o lócus de controle externo pessoas poderosas, reproduzindo os dados encontrados entre os atletas do Handebol. Confirmam os dados que reproduzem achados encontrados por outros pesquisadores que colocam em questão a multidimensionalidade ou a unidimensionalidade do conceito de lócus de controle. Reafirmam a posição atual em relação ao desenvolvimento das escalas de lócus de controle multidimensionais para áreas específicas, pois unidimensionalidade representa uma aspecto muito amplo, exemplo disso, a Multidimentional Helth Locu of Control (MHLC) adaptada no Brasil por (DELA COLETA, 2004). 


\subsubsection{Análise da correlação entre expectativas do lócus de controle e a oscilação espectral da cor da pele dos atletas do Voleibol}

A Escala multidimensional de lócus de controle do esporte avalia as expectativas do controle dos atletas: lócus interno (LCI), quando as expectativas do controle dos acontecimentos no esporte estão voltadas ao próprio atleta; lócus externo, sorte-azar (LCE-SA), quando as expectativas são creditadas ao acaso, destino ou à influência da sorte; e lócus externo pessoas poderosas (LCE-PP), quando as expectativas de controle estão voltadas à influência de figuras de poder ROTTER, CHANCE e PHARES (1972), DELA COLETA (1979, 1982), DELA COLETA (1987, 2004), CONCEIÇÃO (2004).

Com o objetivo de esclarecer as hipóteses sobre o coping por lócus de controle e oscilações da cor da pele dos atletas do Voleibol ingressantes no alto desempenho, a seguir, são analisadas as correlações entre lócus de controle e variações espectrofotométricas da cor da pele nas dimensões definidas pelo espaço CIE $L^{*} a^{*} b^{* 30}$. A investigação dos dados pelo coeficiente de Spearman apresentou os seguintes valores: $\mathbf{L C I}\left(\mathrm{DL}^{*}\right.$ braço, $p=0,854$; $\mathrm{DL}^{*}$ rosto $\mathrm{p}=0,413$ ); $\mathbf{L C l}\left(\mathrm{Da}^{*}\right.$ braço, $p=0,354 ; D^{*}$ rosto $\left.p=0,318\right) ; \quad L C I\left(D b^{*}\right.$ braço, $p=0,650 ; b^{*}$ rosto $\left.p=0,751\right)$; LCE-SA ( $D L^{*}$ braço, $p=0,228$; $L^{*}$ rosto $p=0,751$ ); LCE-SA ( $D a^{*}$ braço, $p=0,590 ; a^{*}$ rosto $p=0,614$ ); LCE-SA ( $D b^{*}$ braço, $p=0,327$; $D b^{*}$ rosto $p=0,206$ ); LCE-PP ( $D^{*}$ braço, $\mathbf{p}=\mathbf{0 , 0 2 6}$; $\mathrm{DL}^{*}$ rosto $\left.p=0,126\right)$; LCE-PP ( $\mathrm{Da}^{*}$ braço, $\mathrm{p}=0,291$; $\mathrm{Da}^{*}$ rosto $\mathrm{p}=0,444$ ); LCE-PP ( $D b^{*}$ braço, $p=0,354 ; b^{*}$ rosto $p=0,089$ ).

A investigação mostrou que houve apenas uma correlação significativa entre o lócus de controle externo pessoas poderosas e $D^{*}$ medido no braço $(p=0,026)$, conforme oscilação dos dados destacados pela FIGURA 23.

\footnotetext{
${ }^{30}$ CIE L* $\mathrm{a}^{*} \mathrm{~b} *$ Sistema de cor proposto pelo Commission Internationale de l'Eclairage, com base na teoria de absorção e reflexão da luz, ver FIGURA 5, p. 42. Os deltas foram calculados subtraindo-se os valores pós-treino dos valores pré-treinos.
} 


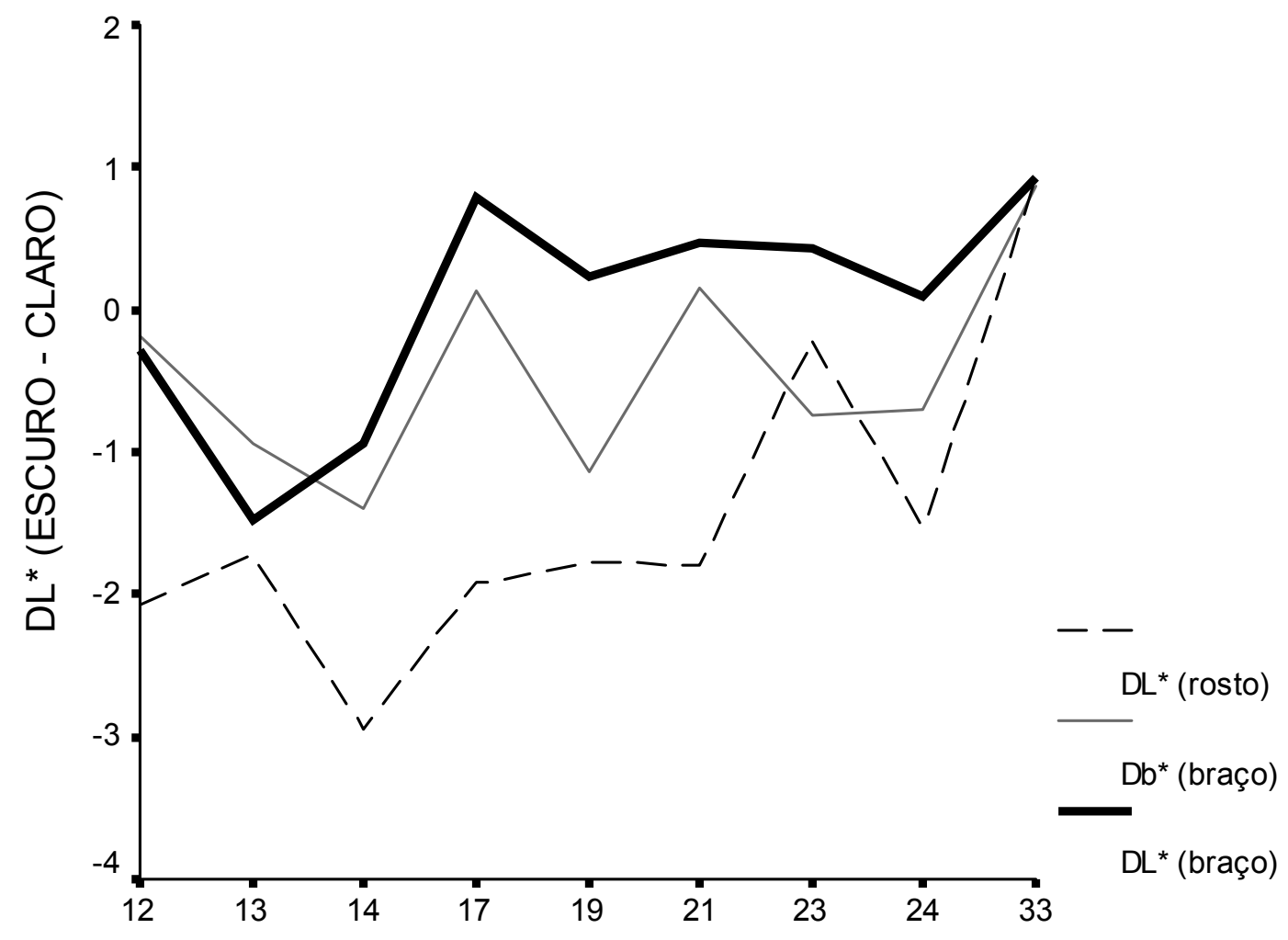

Lócus de controle externo pessoas poderosas (LCE-PP)

FIGURA 23 - Associação do lócus de controle pessoas poderosas e oscilação espectral $D^{*}$ (claro-escuro) no braço e rosto dos atletas de Voleibol

A FIGURA 23 mostra que os atletas ingressantes no esporte de alto rendimento com maiores escores de lócus de controle externo pessoas poderosas (LCE-PP), apresentaram a cor da pele mais clara no rosto e mais amarela e clara no braço, depois dos treinos. Resultados estatisticamente significativos para $\mathrm{DL}^{*}$ das medidas do braço, que são compatíveis aos sentimentos de angústia, pavor e medo, que foram encontrados no estudo desses atletas, e colocam em perspectiva a maior externalidade ao lócus de controle por pessoas poderosas como possibilidade de permanência na instituição. Entretanto, expectativas de lócus de controle externo por pessoas poderosas, não podem confundir-se com a habilidade no traquejo social para lidar com hierarquias. 
A maior externalidade ao lócus de controle por pessoas poderosas evidencia uma estrutura psíquica pouco favorável ao atleta no esporte de alto rendimento, pois revela um mecanismo defensivo que o desmobiliza o Ego ao colocar fora do campo consciente à possibilidade de permanência na instituição por meio dos próprios méritos, ou seja, o atleta "inautêntico". Entretanto, por limitações das figuras reais de autoridade (técnicos e dirigentes), atletas com maiores escores de LCE-PP podem ter a permanência assegurada nas instituições esportivas.

BECKER (2007) em referência a Kierkegaard observa que o homem "inautêntico" se retrai diante das possibilidades, por causa da mentira que se estrutura como caráter nas primeiras experiências da infância, a necessidade de ajustar-se ao mundo e as expectativas dos pais. Assim, o homem inautêntico, não é uma pessoa "própria", pois não desenvolve a singularidade e não age a partir de seu próprio centro. Apresenta-se como pessoa unidimensional, imersa nos jogos imaginários da sociedade, não transcende o condicionamento social.

No contexto da revisão de literatura deste estudo procurou-se mostrar o status atual das pesquisas sobre oscilações da cor da pele por meio do método espectrofotométrico. Ampliar o conceito de "amarelão" inserindo-o no percurso filogenético e ontogenético, o que justifica sua abrangência GIANNETTI (1998), KORZAN, SUMMERS e SUMMERS (2002), VAN DER SALM, SPANINGS, GRESNIGT, WENDELAAR BONGA, FLIK (2005).

A revisão de literatura e os dados obtidos no estudo dos atletas do Handebol e do Voleibol, até este ponto, permitem inferir que as mensurações das oscilações da cor da pele, possam tornar possível por meio de sinais fisiológicos, a avaliação das estratégias adotadas pelos atletas diante do estresse do esporte de alto rendimento, a angústia, o medo e o pavor.

Desse modo, a possibilidade de cognição dos aspetos inconscientes envolvidos pelo "amarelão", reporta a herança genética humana (psicogênese) e a biografia dos indivíduos (ontogênese). Por meio da utilização de instrumentos a possibilidade desenvolvimento cognitivo da cultura, como referido por VYGOTSKY e LURIA (1996). 


\subsubsection{Dados das crenças religiosas dos atletas do Voleibol nas questões iniciais do Inventário Pratt de Crenças Religiosas no Esporte (IPCRE)}

Para esclarecer as hipóteses sobre estresse, oscilação da cor da pele e coping por crenças (lócus de controle e religiosas), a seguir, são apresentados e, parcialmente, analisados os principais dados obtidos com os atletas do Voleibol ingressantes no esporte de alto rendimento institucionalizado, mediante a aplicação do Inventário Pratt de crenças religiosas no esporte IPCRE.

$\mathrm{Na}$ primeira questão, as diferentes modalidades de crenças religiosas são estruturadas sob a perspectiva da religião do atleta; na segunda, pautada na representação de Deus para o atleta; e na terceira, apoiada na sustentação da crença em Deus do atleta.

A seguir, são apresentados os dados destacados nas FIGURAS 24, 25, 26 e os resultados obtidos nas três questões iniciais do IPCRE

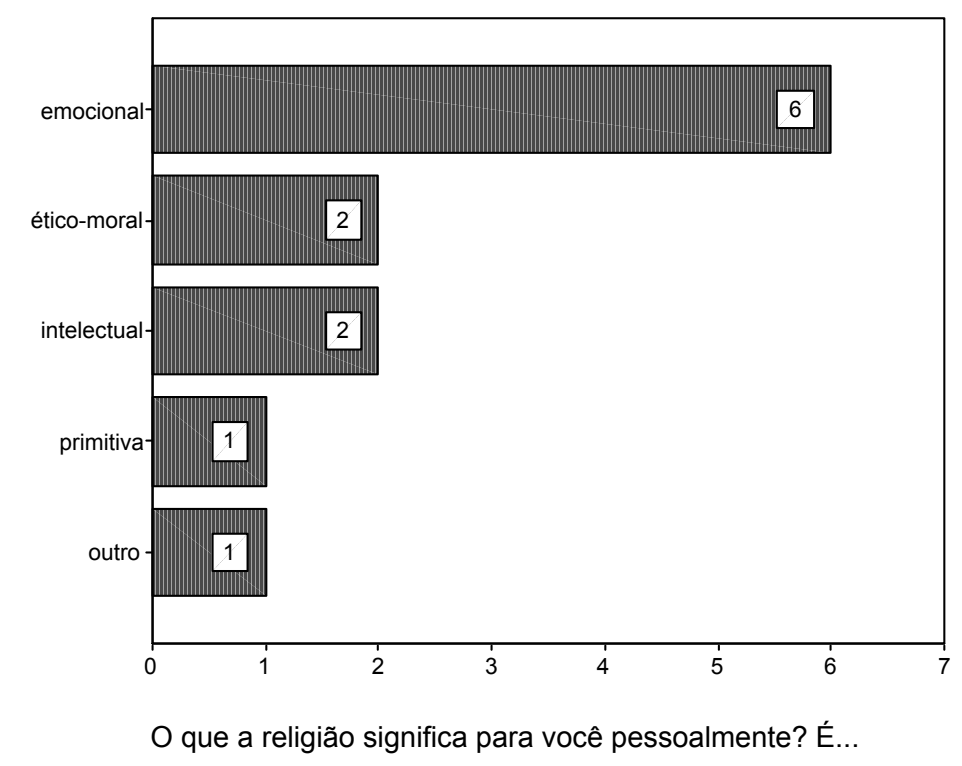

FIGURA 24 - Diferentes modalidades das crenças religiosas dos atletas do Voleibol com base na perspectiva da religião 


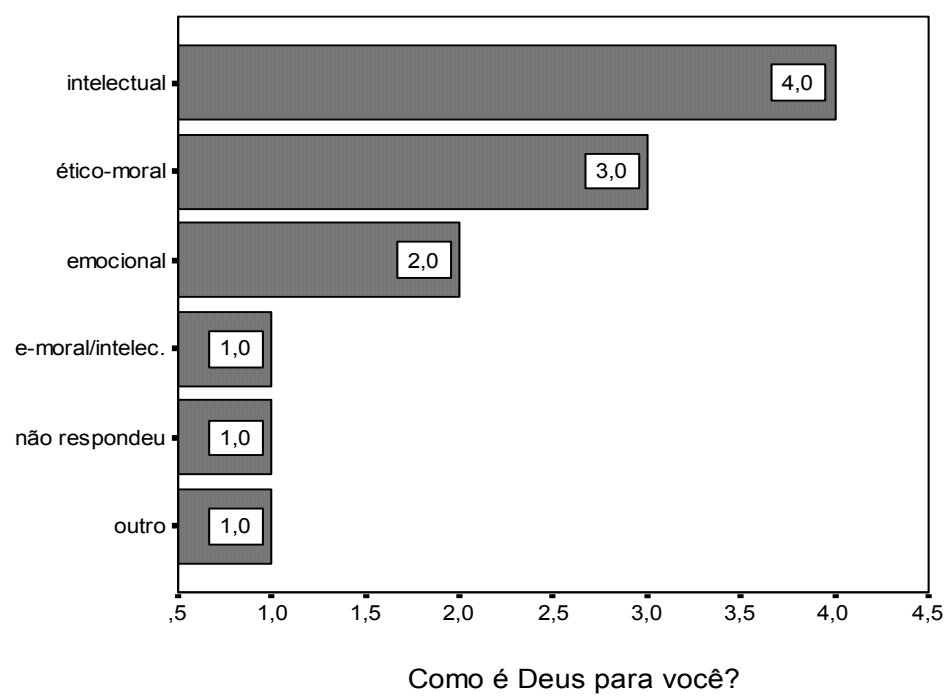

FIGURA 25 - Diferentes modalidades das crenças religiosas dos atletas do Voleibol sob a perspectiva da representacão de Deus

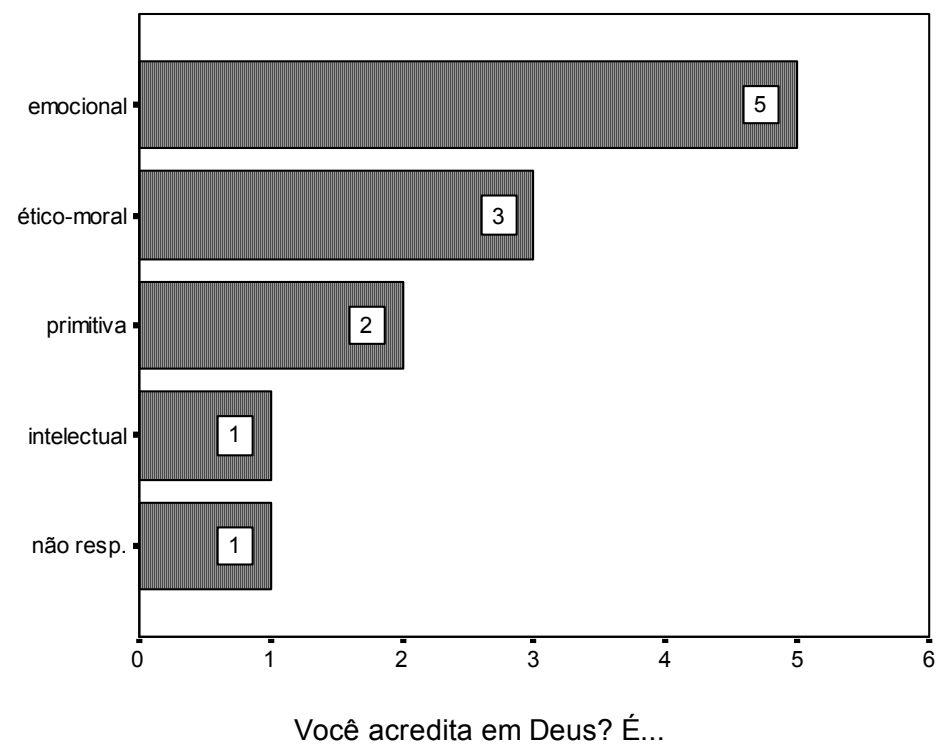

FIGURA 26 - Diferentes modalidades das crenças religiosas dos atletas do Voleibol pela fundamentação da crença 
Os dados obtidos sobre as diferentes modalidades de crenças religiosas destacadas pelas FIGURAS 24, 25, 26 mostram que a crença emocional foi assinalada 13 vezes (36,1\%); a ético-moral, oito $(\mathbf{2 2 , 2} \%)$; a intelectual, sete vezes $(19,4 \%) ;$ a primitiva, três vezes $(8,3 \%)$; a ético-moral e emocional assinaladas simultaneamente na mesma questão, uma vez $(2,8 \%)$; a alternativa outro, duas vezes $(5,6 \%)$; e dois atletas que não revelaram $(5,6 \%)$.

Os dados obtidos dos atletas do Voleibol evidenciam que a crença emocional, a exemplo dos resultados encontrados entre os atletas do Handebol, apresentou-se como modalidade prevalente entre os atletas. Neste contexto, observou-se que os atletas do Voleibol não vivenciavam o estresse no sentido que se define em torno do distresse.

Os atletas do Voleibol passavam por um importante momento na carreira, pelo qual vinham se dedicando em média a 5,6 anos (mínimo três; máximo dez anos). Dados que conferem ao estresse vivenciado pelos atletas do Voleibol características inerentes a fase de alarme, mas, envolvendo os aspectos positivos do estresse, ou seja, o eustresse. As respostas dos atletas sobre a crença emocional, refletiram o tipo coping propiciado por essa modalidade de crença, no momento vivido pelos atletas de Voleibol.

Primeira questão - os relatos dos atletas do Voleibol sobre a crença emocional que refletiram na primeira questão do Inventário Pratt de Crenças Religiosas no Esporte: O que a religião significa para você pessoalmente? É... Na alternativa: Vivenciar, sentir e/ou experienciar a presença de Deus? Como é esta experiência?

Relatos dos atletas: "Aprendi desde cedo com meus pais a freqüentar igrejas católicas e, assim, tomei gosto pela religião. Esta vivência é muito boa porque acreditar em Deus não é só falar, mas também sentir a presença Dele. Assim me fazendo rezar todas as noites pedindo proteção a mim e a meus familiares" (atleta um); "Há uma força suprema que nos guarda e nos livra de todo mal" (atleta cinco); "Deus está no controle de tudo, Ele é o criador de todas as coisas" (atleta oito); "Deus é tudo aquilo de bom que há no mundo, Ele sempre está próximo" (atleta nove); "É ter a sensação que Deus está presente entre nós... 
Dando-nos mais confiança" (atleta dez); "A experiência de sentir a presença de Deus todos os dias da minha vida, ter fé em Deus que ele realiza meus pedidos. Agradecer a Deus pela comida, pela família, entre outros" (atleta 11).

Segunda questão - os relatos dos atletas do Voleibol sobre a crença emocional que refletiram na segunda questão do Inventário Pratt de Crenças Religiosas no Esporte: Como é Deus para você? Na alternativa: Uma energia. Então, como você percebe esta força e/ou energia?

Relatos dos atletas: "Essa energia é inexplicável, sinto uma presença nas coisas que vou fazer, parece que ele me protege. É uma força muito forte que, às vezes, me faz sentir muito seguro nas decisões que vou tomar" (atleta um); "Dono de todas as coisas!!!" (atleta oito); "Deus é uma força ou energia que podemos sentir quando algo diferente acontece com o indivíduo, ou seja, é um poder divino" (atleta nove).

Terceira questão - os relatos dos atletas do Voleibol sobre a crença emocional que refletiram na terceira questão do Inventário Pratt de Crenças Religiosas no Esporte: Você acredita em Deus? É... Na alternativa: Por que você já experimentou ou sentiu SUA presença? Descreva como foi esta experiência.

Relatos dos atletas: "Eu não senti nada muito concreto, mas minha namorada já me contou muitas coisas que aconteceram com ela. Mas, já senti a presença Dele (atleta quatro); "Só pelo simples fato de estar respirando já sinto a presença de Deus" (atleta oito); "Em um momento muito ruim da minha vida, eu recorri a Deus e senti uma imensa paz depois daquele momento" (nove); "Sim, pois quando as coisas não dão certo (...) então, pedimos a Ele e daí tudo começa a se resolver" (atleta dez); "Foi uma experiência muito sobrenatural, senti a graça do senhor - inexplicável" (atleta 11).

Os relatos dos atletas do Voleibol sobre a crença emocional mostram aspectos do coping pelo foco na emoção em situações que demandam enfrentamento WEITEN, LLOYD, DUNN e HAMMER (2008). A identificação da crença com uma força suprema que energiza o atleta gera sentimentos de confiança, proteção, equilíbrio para se persistir em situações de incerteza, é vivenciada pelo sentimento vital em conexão com as funções do sistema nervoso autônomo "Só pelo simples fato de estar respirando, já sinto a presença de Deus". 
A crença ético-moral é caracterizada no IPCRE, como um processo dinâmico que se distingue pela busca de padrões éticos e comportamentais e valores religiosos. Foi a segunda modalidade de crença assinalada com maior freqüência pelos atletas do Voleibol (22,2\%). Os quais, ingressantes em uma instituição esportiva tradicional da cidade de São Paulo, no auge da juventude, força e vigor físico - deixam refletir por meio dos dados colhidos pelo IPCRE, características do coping propiciado pela crença ético-moral.

Primeira questão - os relatos dos atletas do Voleibol sobre a crença éticomoral que refletiram na primeira questão do Inventário Pratt de Crenças Religiosas no Esporte: O que a religião significa para você pessoalmente? É... Na alternativa: Uma atitude do homem para difundir a idéia de Deus e as coisas que são corretas? Explique

Relatos dos atletas: "Na religião, seguimos o que é certo ou errado na visão de Deus" (atleta seis); "Se você não acreditar em Deus? Acreditar em que então? Deus fez a terra, o mar e os homens. Tente respeitar uns aos outros - pois um dia Ele voltará (atleta 12).

Segunda questão - os relatos dos atletas do Voleibol sobre a crença éticomoral que refletiram na segunda questão do Inventário Pratt de Crenças Religiosas no Esporte: Como é Deus para você? Na alternativa: Um princípio que orienta para aquilo que é correto e aquilo que deve ser feito. Explique?

Relatos dos atletas: "Pois nos sentimos mais seguros no que iremos fazer" (dez); "Não posso dizer que o homem foi criado apenas por Deus, porque existem todas as questões científicas por trás, como a teoria da evolução. Mas, Ele permitiu que esse processo acontecesse. Deus é uma forma de disciplinar a sociedade, pois se eu matar ou roubar, por exemplo, vou para o inferno, pelo menos em nossa religião cristã" (o atleta que assinalou as crenças ético-morais e intelectuais).

Assim, Os outros dois que identificaram a crença ético-moral, não complementaram suas respostas nesta questão.

Terceira questão - os relatos dos atletas do Voleibol sobre a crença emocional que refletiram na terceira questão do Inventário Pratt de Crenças Religiosas no Esporte: Você acredita em Deus? É... Na alternativa: Por que ele significa o agir corretamente, ter e divulgar valores morais? Explique? 
Relatos dos atletas: "Nas minhas orações, que sempre são atendidas tenho que ter disciplina. (atleta dois); Como já disse na Questão dois, Ele é um disciplinador (atleta sete); Aquele que deu sentido ao universo, o centro do mundo (atleta seis).

Os dados sobre a crença ético-moral, de certo modo, reafirmam a idéia de que o coping oferecido por esta modalidade de crença está mais voltado para o comportamento (coping pelo foco no problema), ou seja, a busca de disciplina, aliada ao fortalecimento do ego por meio de sua identificação com valores idealizados: "pois nos sentimos mais seguros no que iremos fazer".

A crença intelectual, caracterizada no IPCRE como um processo conflituoso em torno da dúvida, está mais voltada à busca de provas e explicações de natureza intelectual que possam dar conta da angústia existencial, foi assinalada sete vezes $(19,4 \%)$, conforme os dados das FIGURAS 24, 25 e 26 cujas características do coping oferecido por esta modalidade de crença transparecem nos dados complementados pelos atletas:

Primeira questão - os relatos dos atletas do Voleibol sobre a crença intelectual que refletiram na primeira questão do Inventário Pratt de Crenças Religiosas no Esporte: O que a religião significa para você pessoalmente? É... Na alternativa: Uma crença de algo existe? Descreva como é essa crença?

Relatos dos atletas: "É acreditar que um Deus que rege o bem e o mal, tudo o que acontece no mundo" (atleta quatro); "Algo superior a tudo e qualquer coisa. Algo que fez o universo. Fez tudo perfeito para que a vida brotasse e continue a nos influenciar em tudo" (atleta sete).

Segunda questão - os relatos dos atletas do Voleibol sobre a crença intelectual que refletiram na segunda questão do Inventário Pratt de Crenças Religiosas no Esporte: Como é Deus para você? Na alternativa: Aquele que dá sentido ao universo, porque o homem só pode ter sido criado por Deus. Explique?

Relatos dos atletas: "Porque Ele é o criador de todas as coisas, não há sentido na vida sem Ele" (atleta cinco); "Uma pessoa normal que se sacrificou para salvar o resto das pessoas" (seis); "Ele é que nos dá saúde, só Ele sabe o nosso futuro, e Ele é quem determina tudo nesse mundo" (atleta 11); "Com certeza, o 
homem não foi criado por outra coisa - nunca que o homem veio do macaco ou de um meteoro que cai na terra" (atleta 12).

Terceira questão - um relato do atleta do Voleibol sobre a crença intelectual que refletiu na terceira questão do Inventário Pratt de Crenças Religiosas no Esporte: Você acredita em Deus? É... Na alternativa: Com base em algum fato, prova ou argumento? Se for, qual (is)?

Relato do atleta: "Pelo fato de estarmos aqui - alguém nos criou" (atleta dois)

Os dados dos atletas do Voleibol sobre a crença intelectual, embora pouco detalhados, reafirmam os conceitos intelectuais permeados pela dúvida como uma característica central dessa modalidade de crença: "algo que fez o universo", "porque Ele é o criador de todas as coisas, não há sentido na vida sem Ele"; "nunca que o homem veio do macaco ou de um meteoro que caiu na terra".

Dados que caracterizam a estruturação da crença intelectual em torno do sentimento de desconfiança, cujo coping pela avaliação cognitiva WEITEN, LLOYD, DUNN e HAMMER (2008), que estaria mais voltado ao aplanamento da dúvida e da angústia, cuja defesa, a racionalização da crença. A exemplo do que ocorre com as manifestação arquetípicas no esporte, na atualidade.

\subsubsection{Freqüência de dor nas costas e o coping propiciado pela crença da interferência de Deus aos atletas do voleibol}

Dando seqüência ao modelo de análise que busca esclarecer as hipóteses sobre o coping propiciado pelas crenças religiosas, são apresentados e analisados os dados obtidos na questão do IPCRE: Você acredita que Deus poderia ajudar a vencer obstáculos no esporte? Sete atletas $(58,3 \%)$ assinalaram: sim; dois atletas (16,7\%), às vezes; dois atletas (16,7\%), não; e um atleta (8,3\%) não respondeu.

A análise pelo coeficiente de Pearson não mostrou correlação significativa $(p=0,412)$ entre o posicionamento dos atletas do Voleibol nesta questão e o somatório da freqüência dos primeiros 23 itens da LSS-VAS, mas houve correlação significativa $(p=0,005)$ com a freqüência do item "Sinto dores nas costas", aquele que revelou maior freqüência entre os atletas de Voleibol: cinco atletas $(41,7 \%)$ 
citaram que freqüentemente sentem dores nas costas e seis $(50,0 \%)$ raramente sentem dores nas costas; e um (8,3\%) não respondeu.

A associação entre a percepção de Deus como ajuda para superar obstáculos no esporte e a freqüência de dores nas costas, pelos dados da FIGURA 27.

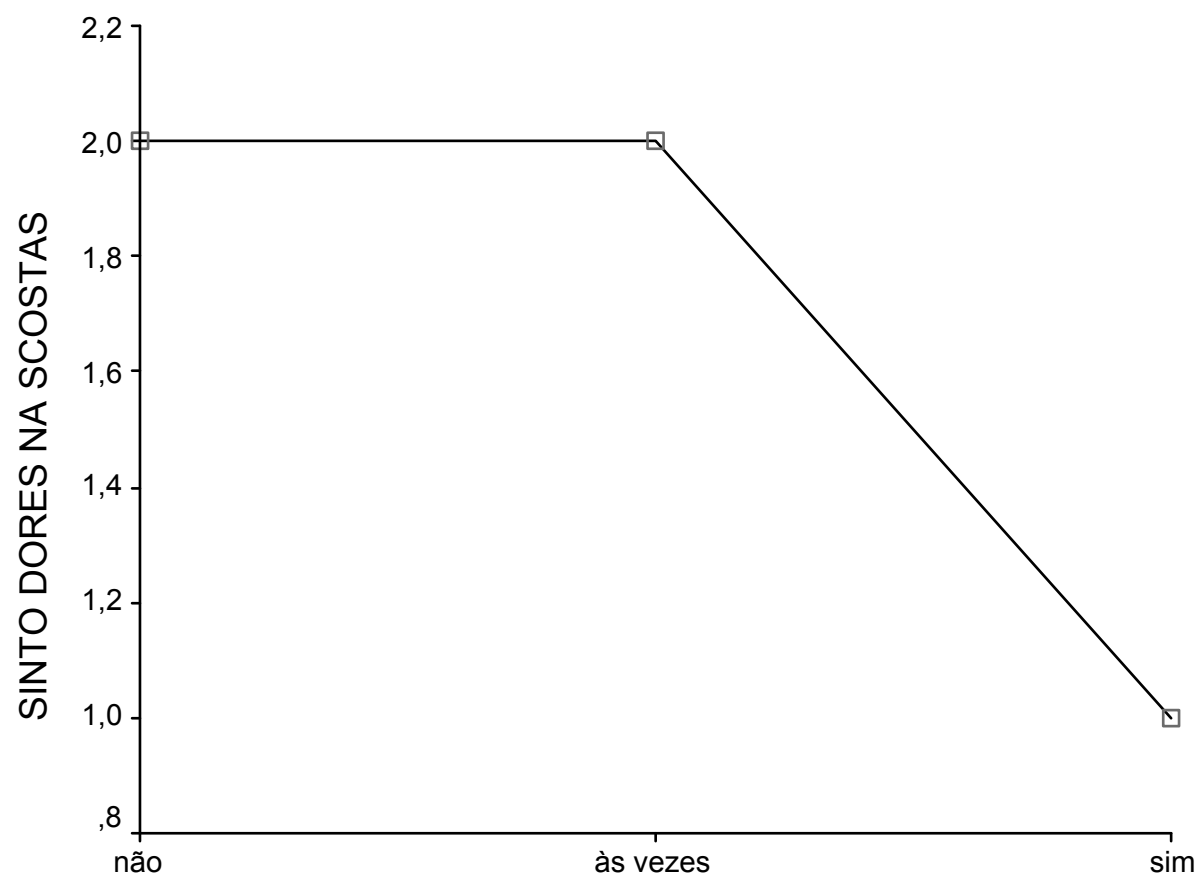

Deus poderia ajudar a vencer obstáculos no esporte?

FIGURA 27 - Associação entre freqüência de dores nas costas e coping pela crença em Deus, como ajuda para vencer obstáculos no Voleibol

A FIGURA 27 mostra os atletas que revelaram acreditar que Deus ajuda vencer obstáculos no esporte, sentem dores nas costas com menor freqüência. Já, os atletas que disseram: não e, às vezes, sentem dores nas costas com maior freqüência, inferindo-se que possam se esforçar mais, porque o lócus do controle para superar obstáculos estaria voltado ao próprio atleta, por isso, sentem mais dores nas costas ou que o coping da crença em Deus como ajuda para superar obstáculo propiciaria ao atleta respeitar mais seus próprios limites. 
A complementação dos dados obtidos dos atletas do Voleibol, ingressantes no esporte de alto rendimento, sobre a crença na interferência de Deus para superar obstáculos no esporte possibilita ampliar a análise do coping pelas crenças religiosas como ajuda para superar dores nas costas. Os atletas que assinalaram: sim, acreditam que Deus pode ajudar superar obstáculos no esporte, complementaram seus posicionamentos com os seguintes dados: "Ele ajuda no que for melhor para nós" (atleta dois); "Os psicológicos, Deus sempre me ajuda" (atleta três); "Sinto que algo de ruim acontece agora, mas, no final Ele me recompensa" (atleta quatro); "Eu acho que se você se dedicar bastante na hora "h" ele ajuda" (atleta cinco); "Ele está no controle de todas as coisas !!!" (atleta oito); "Sim, pois sem ele nada seríamos" (atleta dez); "Porque através da minha fé e santidade o Senhor me capacita" (atleta 11).

Os atletas que assinalaram: às vezes, complementaram o posicionamento na questão com as seguintes informações: "O maior obstáculo no esporte que você pratica é você mesmo, porque quem treinou foi você. Às vezes, ajuda sim pedir proteção na hora do jogo, mas não vai fazer que você consiga saltar mais ou ter mais força" (atleta um). O outro atleta não forneceu mais dados sobre seu posicionamento (atleta doze).

Os atletas que não acreditam que Deus possa ajudar a vencer obstáculos no esporte complementaram com os seguintes dados: "Ele colocou as dificuldades para que possamos vencê-las e evoluir" (atleta sete); "Não quando se diz sobre vitórias, sobre jogos ou que Ele ajuda o esforço do que necessita. Mas sim quando se diz de contusão ou algo que interfere na paz natural do indivíduo" (atleta nove). O outro atleta não forneceu mais dados sobre seu posicionamento (atleta seis).

Os dados colocam em perspectiva a complexidade do coping que as crenças religiosas podem oferecer aos atletas, pois os atletas do Voleibol que mostraram que, às vezes, e que, não: acreditam que Deus possa ajudar a vencer obstáculos no esporte; sentem dores nas costas com maior freqüência, mas, por outro plano, denotam se esforçar mais para superar as dificuldades para adaptar-se à instituição. Já, os atletas que acreditam que Deus poderia ajudar a vencer obstáculos no esporte raramente sentem dores nas costas, inferindo-se que o coping pela crença em Deus como ajuda para superar obstáculos implica maior confiança: "Ele ajuda no 
que for melhor para nós”; “...no final, Ele me recompensa”; “...na hora "h”, ele ajuda”; "Ele está no controle de todas as coisas !!!”; “... Pela minha fé e santidade, o senhor me capacita". Os atletas acreditam que Deus poderia ajudar a vencer obstáculos, assim respeitam mais os limites impostos pela dor, que os atletas que, às vezes, não acreditam na possibilidade de interferência de Deus, estariam mais propensos a ultrapassar seus limites de capacidade de resistência a dor.

Confirmando esta tendência, os dados obtidos na questão do IPCRE: E nas derrotas, Deus teria alguma participação? Oito $(66,7 \%)$ assinalaram sim; três $(25,0 \%)$ assinalaram não; e um $(8,3 \%)$ não respondeu. A análise pelo coeficiente de Pearson mostrou correlação $(p=\mathbf{0 , 0 3 3 )}$ entre os posicionamentos dos atletas do Voleibol nesta questão e a freqüência do item da LSS-VAS "Sinto dores nas costas". A associação da percepção da interferência de Deus nas derrotas e a freqüência de dores nas costas é ilustrada pela FIGURA 28.

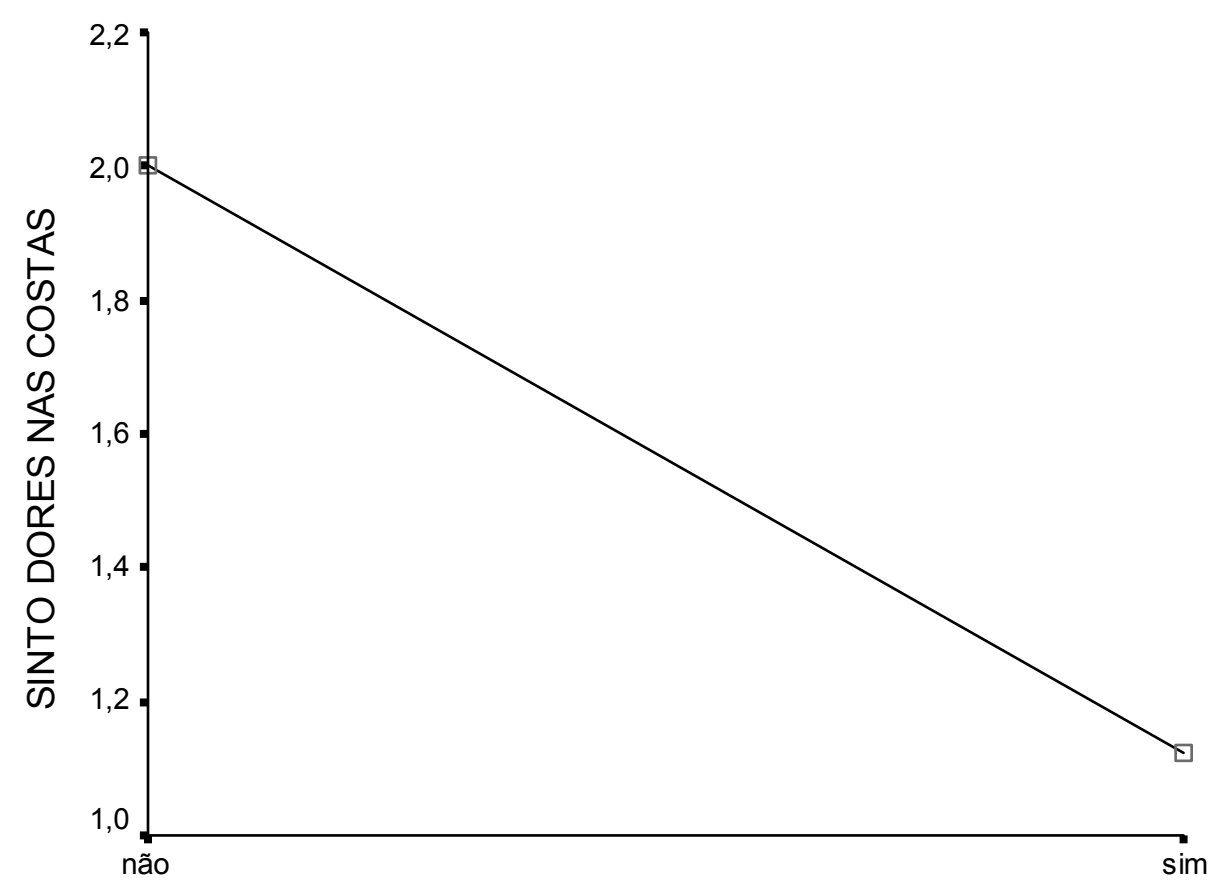

Deus teria alguma participação nas derrotas?

FIGURA 28 - Associação entre freqüência de dores nas costas e coping da crença da interferência de Deus nas derrotas 
A FIGURA 28 mostra os atletas que revelaram acreditar que Deus teria participação nas derrotas, sentem dores nas costas com menor freqüência. Já, os atletas que afirmaram não: Deus não teria participação nas derrotas, revelaram que sentem dores nas costas com maior freqüência. Inferindo-se que possam se esforçar mais nos treinos, por isso, sentem mais dores ou que a crença oferece um coping que lhes possibilita respeitar mais seus próprios limites.

Os atletas que assinalaram que Deus teria participação nas derrotas complementaram seus posicionamentos com os seguintes dados: "Ele ajuda no que for melhor para nós" (atleta dois); "Com as derrotas, Ele me ensina muita coisa" (atleta quatro); "Pois, aquele time que busca sempre, faz uma oração para que Deus proteja o seu e o outro time; Deus sempre olha com carinho" (atleta cinco); "Para que possamos nos reerguer, reenfrentar e vencer" (atleta sete); "Nada acontece por acaso" (atleta oito); "Sim, pois nas derrotas podemos refletir e aprender o que fizemos de errado" (atleta dez); "Porque tudo é propósito de Deus, e alguma coisa Ele quis nos ensinar com a derrota" (atleta 11); "Deus sabe o que faz, se aquele jogo não era para ter vencido, com certeza, deve ter alguma causa..."

Estes dados colocam em perspectiva a complexidade do coping que as crenças religiosas podem oferecer aos atletas, pois os atletas do Voleibol que mostraram não, esforçam-se mais para obter a vitória que aqueles que revelaram sim.

\subsubsection{Oscilação espectral da cor da pele $\mathrm{Db}^{*}$ (azul-amarelo) no braço e o coping pela crença da interferência de Deus no Voleibol}

A análise pelo coeficiente de Spearman mostrou correlação significativa $(p=$ 0,033) entre a oscilação da cor da pele do braço no eixo $\mathrm{Db}^{*}$ (azul-amarelo) e o posicionamento dos atletas na questão do IPCRE "Você acredita que Deus poderia ajudar a vencer obstáculos no esporte", ilustrada pelos dados da FIGURA 29. 


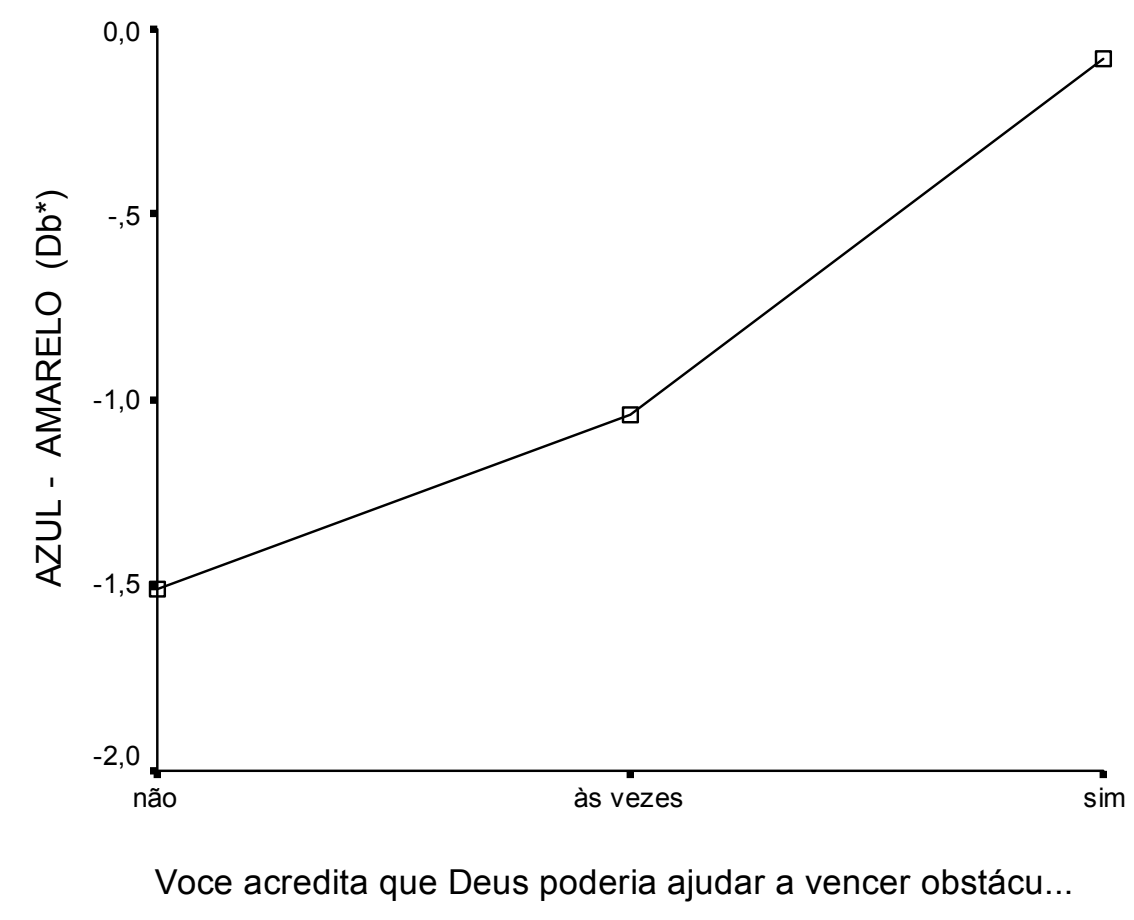

FIGURA 29 - Associação da oscilação espectral Db* (azul-amarelo) e coping da crença na ajuda de Deus para vencer obstáculos no esporte

Os dados da FIGURA 29 mostram que os atletas que revelaram não acreditar que Deus possa ajudar vencer obstáculos no esporte, apresentaram a cor da pele significativamente menos amarelada depois do treino $\left(-\mathrm{Db}^{*}\right)$. Os atletas que revelaram acreditar que Deus possa ajudar vencer obstáculos no esporte mostraram pouca oscilação.

Estes resultados permitem inferir que os atletas ingressantes no Voleibol de alto rendimento, na fase inicial do estresse (alarme), na concepção de Selye, que mostraram utilizar estratégias de coping com foco voltado para o problema, apresentavam a cor da pele significativamente mais amarela antes do treino, inferências que podem ser abstraídas dos relatos desses atletas: "Ele colocou as dificuldades para que possamos vencê-las e evoluir"; “... sim (ajuda) quando se diz de contusão ou algo que interfere na paz natural do indivíduo". 


\subsection{Apresentação dos dados dos atletas da Ginástica Artística}

Os dados da Ginástica Artística constituíram-se de uma amostra de seis atletas pertencentes a um clube social e esportivo da cidade de São Paulo. Em seus quadros, constam atletas de reconhecimento mundial. A média de idade foi 20,33 anos (mínimo 18 e máximo 24); a escolaridade: dois de nível superior incompleto e quatro de nível médio. A confissão religiosa: quatro católicos, um católico e espírita e um que revelou apenas acreditar em Deus.

O tempo médio de experiência dos atletas na modalidade foi de 10,9 anos (mínimo 8,2 e máximo 16,8) e a idade média de iniciação no esporte 9,4 anos.

Os dados mostraram que os atletas mais velhos vivenciavam momentos de tensão, dúvidas e incertezas que marcam o final da fase competitiva da carreira. Por se tratar de uma modalidade, caracterizada pelo rígido controle de peso e altura e, mundialmente, conhecida pela iniciação precoce. Em alguns países, ocorre por volta dos seis, cinco e até quatro anos de idade.

A coleta de dados realizou-se no período de classificação dos ginastas aos Jogos Olímpicos - mas, os atletas pesquisados não se classificaram. Treinavam separados da equipe que participou das Olimpíadas de Pequim 2008. Dados que caracterizam o quadro vivido pelos atletas da Ginástica Artística, como semelhante ao Handebol. Significa que, apesar das diferenças entre as modalidades, a situação vivida pelos atletas da Ginástica Artística e handebol, de certo modo, assemelha-se. Inferindo-se que envolveriam reações ao estresse que se aproximariam mais das características da segunda fase: resistência, conforme os conceitos clássicos de Selye, definidos na Síndrome Geral da Adaptação ao estresse NITSCH, ALLMER, HACKFORT, LAZARUS, MCGRATH, SELYE e UDRIS (1981).

Diferenciam-se completamente da fase vivida pelos atletas de Voleibol, nos termos dos conceitos clássicos de $\mathrm{H}$. Selye, característicos da primeira fase de adaptação ao estresse, fase de alarme, dado que os atletas ingressaram nos quadros do esporte de alto rendimento, apenas há três meses na instituição. Dados que pressupõem diferentes sintomas do estresse inerentes ao esporte de alto rendimento. 


\subsubsection{Caracterização das condições da coleta de dados com os atletas da Ginástica Artística}

Os dados foram coletados em um ginásio coberto, antes e depois da realização dos exercícios da rotina normal do primeiro treino dos atletas nas manhãs de sexta-feira. A principal característica da pesquisa com os atletas da ginástica foi a natureza realista do estudo, pois as condições da coleta foram praticamente as mesmas encontradas nas competições do calendário oficial dos atletas, excetuandose o fato que não havia pressão por resultados.

As medições da cor da pele antes do treino, dados sobre crenças religiosas e lócus de controle foram coletados antes do aquecimento corporal livre. As medições pós-treino do masculino foram realizadas individualmente por atleta, após giro transversal em salto duplo de frente sobre a mesa - gesto técnico que exige treinamento intensivo para se atingir o grau de perfeição.

Os dados da ginasta do feminino foram coletados após a realização de piruetas e mortais na trave olímpica, gestos técnicos que implicam demonstração de elegância, equilíbrio e controle. Somente após a coleta das informações sobre a cor da pele, a Lista de Sintomas de Estresse (LSS-VAS) e a ficha dos dados técnicos dos atletas foram aplicadas.

O objetivo era esclarecer as hipóteses do estudo sobre as implicações do estresse e as variações da cor da pele, o "amarelão", mediado pelo coping das crenças religiosas e lócus de controle dos atletas. Por causa do tamanho reduzido da amostra de ginastas, os dados foram analisados apenas no conjunto da totalidade com as outras modalidades. 


\subsubsection{Principais resultados obtidos sobre a oscilação da cor da pele dos atletas da Ginástica Artística pelo método espectrofotométrico}

Os valores obtidos pela mensuração da cor da pele na parte interna do braço e no rosto dos atletas da Ginástica Artística, relativos aos valores $L^{*} a^{*} b^{* 31}$ e seus respectivos deltas ${ }^{32}$ pré e pós-treinos - valores mínimos, máximos, média e desviopadrão são destacados na dados da TABELA 9.

TABELA 9- Valores espectrais da variação $L^{*} a^{*} b^{*}$ pré e pós-treinos s no braço e no rosto dos atletas da Ginástica Artística

\begin{tabular}{|c|c|c|c|c|c|}
\hline & $\mathrm{N}$ & Mínimo & Máximo & Média & $\begin{array}{l}\text { Desvio } \\
\text { padrão }\end{array}$ \\
\hline $\bar{L}$ (braço) & 6 & 54,47 & 64,03 & 57,8083 & 3,4496 \\
\hline$L$ (rosto) & 6 & 55,04 & 62,99 & 58,0567 & 2,8680 \\
\hline DL (braço) & 6 &,- 80 & 1,21 & ,1100 & ,8706 \\
\hline DL (rosto) & 6 & $-1,26$ & ,06 &,- 6483 & ,4806 \\
\hline$a^{*}$ (braço) & 6 & 8,42 & 11,28 & 9,8250 & ,9336 \\
\hline$a^{*}$ (rosto) & 6 & 11,64 & 15,77 & 13,7867 & 1,7987 \\
\hline $\mathrm{Da}^{*}$ (braço) & 6 & $-1,27$ & 6,29 & 1,1217 & 2,6429 \\
\hline $\mathrm{Da}^{*}$ (face) & 6 & ,24 & 2,07 & 1,2783 & ,6569 \\
\hline$b^{*}$ (braço) & 6 & 17,93 & 21,84 & 19,7033 & 1,7685 \\
\hline$b^{*}($ face $)$ & 6 & 15,39 & 22,82 & 18,1800 & 2,5783 \\
\hline $\mathrm{Db}^{*}$ (braço) & 6 & $-4,23$ &, 59 &,- 7350 & 1,7694 \\
\hline $\mathrm{Db}^{*}$ (face) & 6 & $-1,11$ & ,29 &,- 5467 & ,5413 \\
\hline casos válidos & 6 & & & & \\
\hline
\end{tabular}

\footnotetext{
${ }^{31}$ CIE L* $a^{*} b^{*}$ - sistema de unidade de medida de cor proposto pelo Commission Internationale de E'clairege com base na teoria de absorção e reflexão da luz. FIGURA 5, p. 42.

L* (claro-escuro): o valor zero corresponde à absorção máxima da luz (preto) e 100 à reflexão máxima (branco) $\mathrm{a}^{*}$ (vermelho-verde): os valores negativos correspondem ao verde e os valores positivos ao vermelho $\mathrm{b}^{*}$ (azul-amarelo ): os valores negativos correspondem ao azul e os valores positivos ao amarelo
} 
Pelos dados da TABELA 9, houve variações da cor da pele dos atletas de ginástica nos três eixos definidos pelo espaço CIE $\mathrm{DL}^{*}$, $\mathrm{Da}^{*}$ e $\mathrm{Db}^{*}$. Assim os valores mais negativos de $\mathrm{Db}^{*}$ no braço foram encontrados entre os atletas da Ginástica Artística, pois foram os atletas que apresentaram a cor da pele mais amarelada no braço, depois da execução dos exercícios.

\subsubsection{Principais resultados obtidos sobre a freqüência e intensidade dos sintomas de estresse dos atletas da Ginástica Artística por meio da Lista de Sintomas de Stress (LSS-VAS)}

Os valores da freqüência dos sintomas de estresse dos atletas da Ginástica foram obtidos pelo somatório da freqüência parcial dos 59 itens de sintomas de estresse da Lista de Sintomas de Stress LSS-VAS, que podem variar de zero a 177. A divisão desses valores em quartis, considerando-se a quase ausência de sintomas de estresse 13\% (primeiro quartil), conforme verificou o Prof. Dr. Esdras Guerreiro Vasconcellos ${ }^{33}$. Assim, os valores iguais ou inferiores a 23, denotando baixa freqüência dos sintomas de estresse. O segundo quartil compreendeu valores de 24 a 74, indicando média freqüência de sintomas de estresse. O terceiro quartil mostrou valores de 75 a 125, alta freqüência dos sintomas de estresse e o quarto quartil, valores entre 126 e 177, que denotam altíssima freqüência de sintomas de estresse

Os valores obtidos da intensidade de sintomas de estresse LSS-VAS, que podem variar de zero a 265,5 - considerando-se a baixa intensidade $13 \%$. Resultou valores iguais ou inferiores a 34,5 compreenderam o primeiro quartil, denota baixa intensidade do sintoma de estresse; segundo quartil, valor de 35 a 111, denota média intensidade, terceiro quartil, valor de 112 a 188, denota alta intensidade; e o quarto, valor entre 189 e 265,5, denota altíssima intensidade dos sintomas de estresse.

Os dados sobre freqüência e intensidade dos sintomas de estresse dos atletas de ginástica são destacados na TABELA 10.

\footnotetext{
${ }^{33}$ Comunicação pessoal
} 
TABELA 10- Freqüência dos sintomas do estresse dos atletas da Ginástica por meio da Lista de Sintomas de Stress LSS-VAS

\begin{tabular}{|c|c|c|c|c|c|c|}
\hline & & & & $\begin{array}{r}23 \text { ITENS } \\
\text { (freqüência) }\end{array}$ & $\begin{array}{r}59 \text { ITENS } \\
\text { (freqüência) }\end{array}$ & $\begin{array}{r}59 \text { ITENS } \\
\text { (intensidade) }\end{array}$ \\
\hline \multirow{8}{*}{$\begin{array}{l}\text { Ginástica } \\
\text { artística }\end{array}$} & \multirow[t]{5}{*}{ masculino } & 1 & & 22,00 & 55 & 102,60 \\
\hline & & 2 & & 26,00 & 52 & 43,20 \\
\hline & & 3 & & 26,00 & 73 & 175,40 \\
\hline & & 4 & & 27,00 & 70 & 127,40 \\
\hline & & Total & $\mathrm{N}$ & 4 & 4 & 4 \\
\hline & \multirow[t]{2}{*}{ feminino } & 1 & & 27,00 & 59 & 79,70 \\
\hline & & Total & $\mathrm{N}$ & 1 & 1 & 1 \\
\hline & Total & $\mathrm{N}$ & & 5 & 5 & 5 \\
\hline
\end{tabular}

Pelos dados da TABELA 10, os atletas da ginástica pesquisados apresentaram média freqüência de sintomas de estresse (segundo quartil). Quanto à intensidade, quatro atletas apresentaram média intensidade e um atleta alta intensidade (terceiro quartil).

\subsubsection{Expectativas do lócus de controle dos atletas da Ginástica Artística por meio da Escala Multidimensional de Lócus de Controle do esporte}

Estatísticas descritivas das expectativas do lócus de controle: valores mínimos, máximos, médias e desvios-padrão dos dados obtidos pela aplicação da Escala Multidimensional de Lócus de Controle do Esporte (EMLCE) aos atletas da Ginástica Artística são apresentadas pela TABELA 11. 
TABELA 11 - Expectativas do lócus de controle dos atletas da Ginástica Artística

\begin{tabular}{lrrrr}
\hline \hline & \multicolumn{2}{c}{$\begin{array}{c}\text { Lócus de controle } \\
\text { interno }\end{array}$} & $\begin{array}{l}\text { Lócus de controle externo } \\
\text { sorte-azar }\end{array}$ & $\begin{array}{r}\text { Lócus de controle externo } \\
\text { pessoas poderosas } \\
(\text { LCI })\end{array}$ \\
\hline $\mathrm{N}$ & 5 & 5 & 5 \\
& $\begin{array}{l}\text { casos } \\
\text { válidos } \\
\text { dados } \\
\text { faltosos }\end{array}$ & 1 & 1 & 1 \\
& 33,80 & 19,00 & 24,20 \\
Média & 6,69 & 6,71 & 4,76 \\
Desvio padrão & 27 & 8 & 18 \\
Mínimo & 45 & 26 & 30 \\
Máximo & & & \\
& & & & \\
\hline \hline
\end{tabular}

A TABELA 11 mostra os dados sobre lócus de controle obtidos dos atletas da Ginástica Artística: lócus de controle interno LCI 33,80 (média alta de lócus de controle interno); lócus de controle externo sorte-azar LCE-AS 19,00 (média baixa de lócus de controle externo sorte azar); e lócus de controle externo pessoas poderosas LCE-PP 24,20 (média baixa de lócus de controle externo pessoas poderosas).

\subsubsection{Crenças religiosas dos atletas da Ginástica Artística pelo Inventário Pratt de Crenças Religiosas no Esporte (IPCRE)}

Os principais dados obtidos com os atletas da Ginástica Artística, mediante a aplicação do Inventário Pratt de crenças religiosas no esporte, nas primeira, segunda e terceira questões, são apresentados nas FIGURAS 30, 31 e 32. 


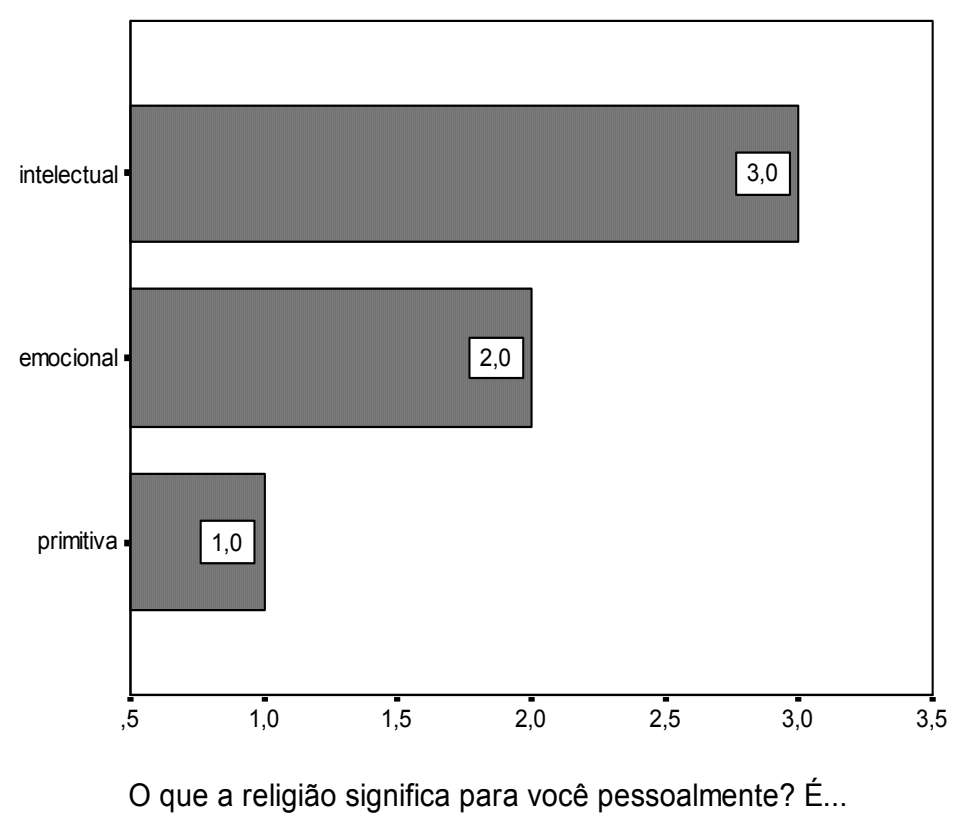

FIGURA 30 - Diferentes modalidades das crenças religiosas dos atletas da Ginástica Artística com base na perspectiva da religião

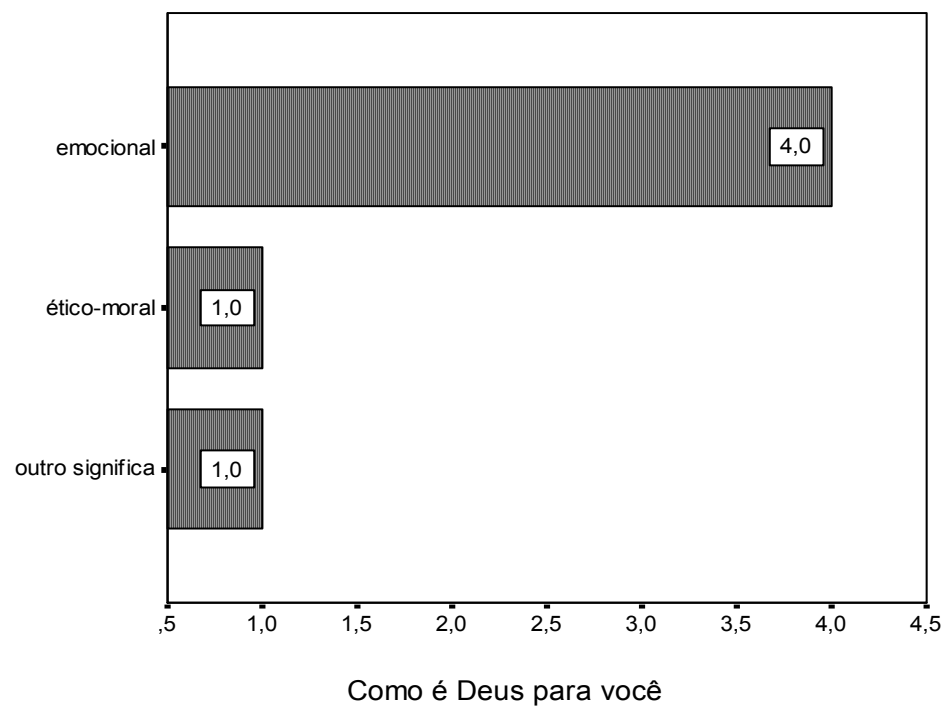

FIGURA 31 Diferentes modalidades das crenças religiosas dos atletas da Ginástica Artística sob a perspectiva da representação de Deus 


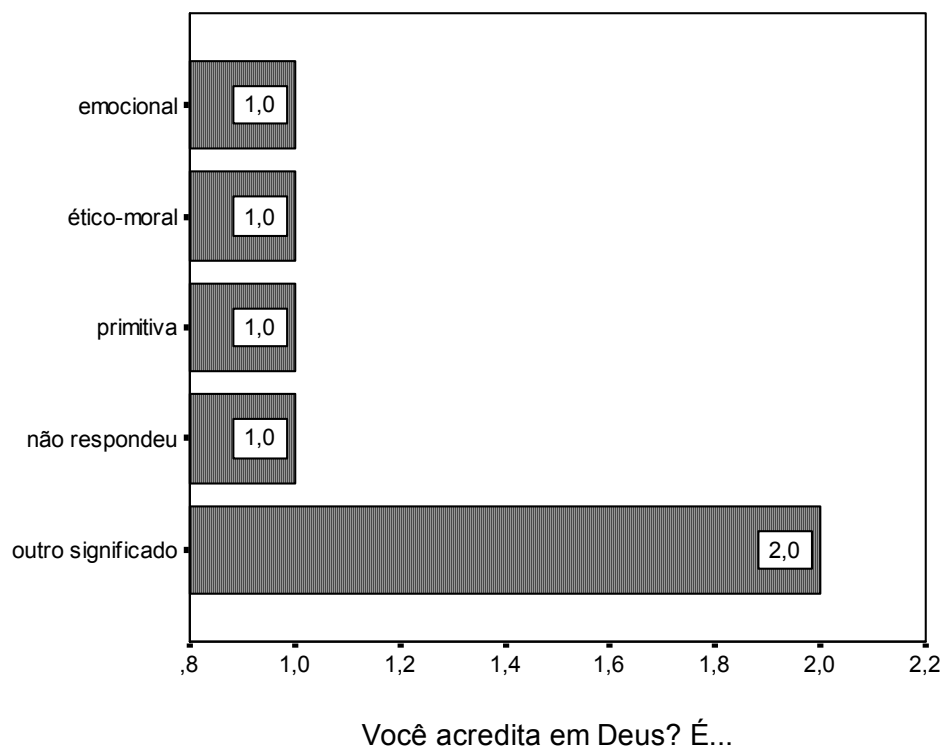

FIGURA 32 Diferentes modalidades das crenças religiosas dos atletas da Ginástica Artística pela fundamentação da crença

Os dados destacados pelas FIGURAS 30,31 e 32 mostram que a crença emocional foi assinalada (38,9 \% - sete vezes); a intelectual (16,7\% - três vezes); a ético-moral (11,1\% - duas vezes); a primitiva $(11,1 \%)$; outros significados três vezes (16,7\%), e não respondeu (5,6\%).

A crença emocional também se revelou como modalidade prevalente entre os atletas da Ginástica Artística, a exemplo dos resultados encontrados no Handebol e Voleibol. Os dados obtidos dos atletas da Ginástica na questão sobre a crença emocional permitem refletir sobre o coping emocional propiciado por essa modalidade no momento vivido pelos atletas.

Primeira questão - os relatos dos atletas da Ginástica Artística sobre a crença emocional que refletiram na primeira questão do Inventário Pratt de Crenças Religiosas no Esporte: $\mathrm{O}$ que a religião significa para você pessoalmente? É... Na alternativa: Vivenciar, sentir e/ou experienciar a presença de Deus, Como é esta experiência? 
Relatos dos atletas: "Saber todos os dias que não estamos sozinhos,... e nas horas críticas não temos que ter medo e sim enfrentar com tudo, pois nunca estamos só" (25); "Quando acreditamos em Deus, sempre sentimos ele por perto para nos proteger e ajudar" (27).

Segunda questão - os relatos dos atletas da Ginástica Artística sobre a crença emocional que refletiram na segunda questão do Inventário Pratt de Crenças Religiosas no Esporte: Como é Deus para você? Na alternativa: Uma energia. Então, como você percebe esta força e/ou energia?

Relatos dos atletas: "Como o 'ar' ou até mesmo os átomos, pois não os vemos, mas sabemos que estão lá" (25); "Porque Ele me dá força e energia basta acreditar Nele" (27); "Percebo quando estou mal. Gosto de conversar com Ele, sento e fico pensando Nele, sinto que Ele está por perto. Acho que é essa energia entre agente, uma simples conversa” (28); “ Uma energia que move o universo e orienta as pessoas para o caminho do bem através de sensações" (30)

Terceira questão - o relato de um atleta da Ginástica Artística sobre a crença emocional que refletiu na terceira questão do Inventário Pratt de Crenças Religiosas no Esporte: Você acredita em Deus? É... Na alternativa: Por que você já experimentou ou sentiu SUA presença? Descreva como foi esta experiência.

Relato do atleta: "Acredito que exista algo superior e divino, pois de alguma forma todos nós sentimos, uns mais, outros menos" (25).

\subsection{Análise da oscilação espectral da cor da pele dos atletas da Ginástica Artística, Handebol e Voleibol e a freqüência de sintomas de estresse}

A análise pelo coeficiente de correlação Spearman dos dados obtidos pelas freqüências de sintomas de estresse LSS-VAS e os deltas das diferenças da cor da pele nas medições do braço e no rosto por meio dos valores espectrais DL* (claroescuro), $\mathrm{Da}^{*}$ (vermelho-verde) e $\mathrm{Db}^{*}$ (azul-amarelo) mostrou os seguintes resultados: $D^{*}$ (braço: $p_{23}=0,357 ; p_{59}=0,488$ - rosto: $p_{23}=0,975, p_{59}=0,000$ ); Da* (braço: $p_{23}=0,459 ; p_{59}=0,801$ - rosto: $p_{23}=0,703, p_{59}=0,167$ ), e Db* (braço: $p_{23}=0,806 ; p_{59}=0,076$ - rosto: $\left.p_{23}=0,539 p_{59}=0,122\right)$. 
Houve altíssima correlação entre o somatório da freqüência dos sintomas de estresse do grupo formado pelos atletas com maior experiência no esporte de alto rendimento, Handebol e Ginástica Artística e a oscilação da cor da pele DL* (claroescuro) nas medições no rosto $\left(\mathbf{p}_{59}=\mathbf{0 , 0 0 0}\right)$, conforme a oscilação dos dados representados pela FIGURA 33.

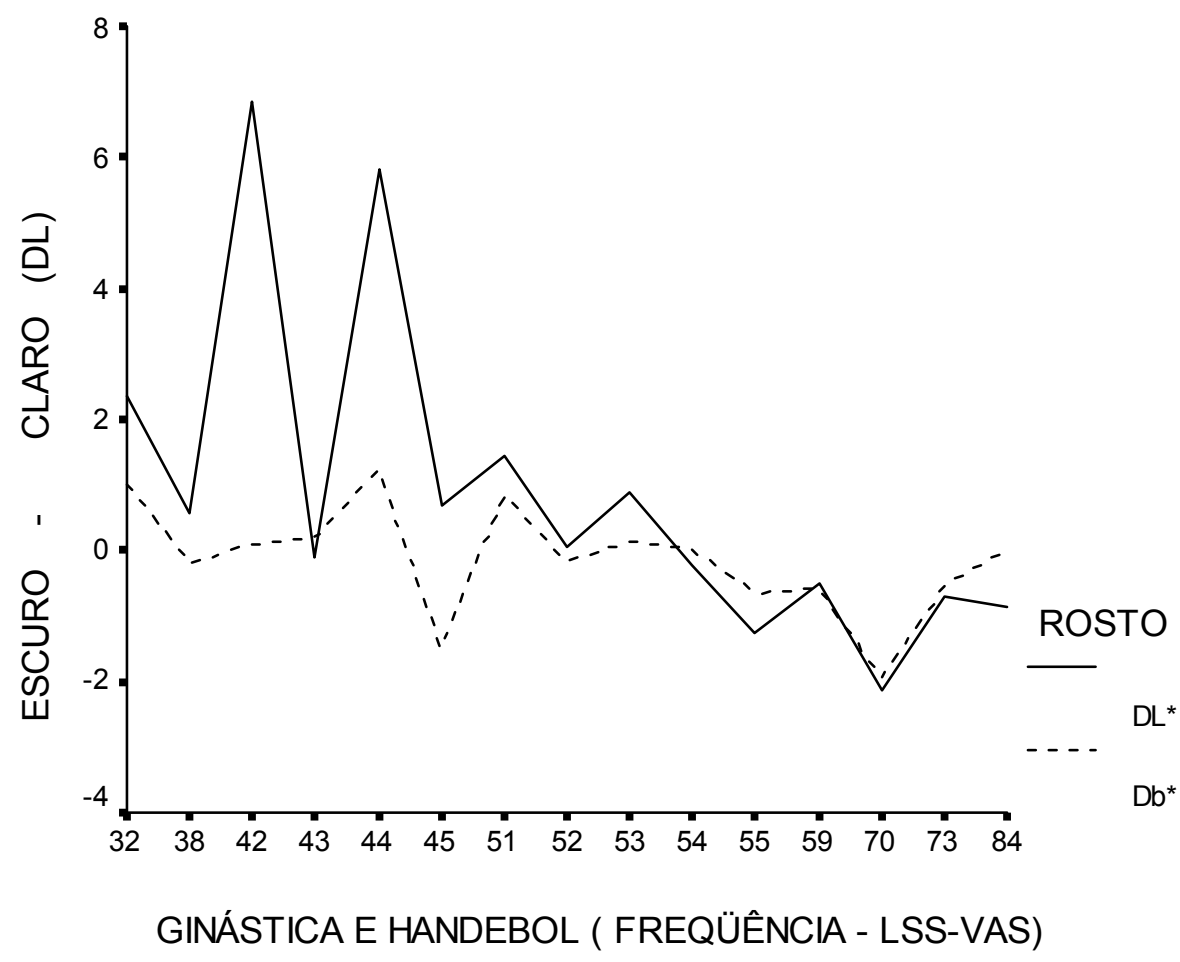

FIGURA 33 - Associação entre freqüência de sintomas de estresse e oscilação DL $^{*}$ (claro-escuro) no rosto dos atletas da Ginástica Artística e Handebol

A FIGURA 33 mostra que o somatório da freqüência dos sintomas de estresse dos atletas do Handebol e Ginástica Artística tendem a correlacionar-se com os valores mais negativos dos $\mathrm{DL}^{*}$ e $\mathrm{Db}^{\star 34}$. Os atletas que revelaram maiores escores de freqüência de sintomas de estresse apresentavam-se significativamente mais pálidos (claro) e amarelados antes do treino.

\footnotetext{
${ }^{34}$ Os deltas das diferenças das oscilações da cor da pele foram calculados subtraindo-se os valores obtidos nas medições pós-treinos das medições pré-treinos.
} 
Os itens que revelaram as correlações mais fortes $(p<0,02)$, com a oscilação espectral da cor da pele $D L^{*}$ nas medições no rosto e a freqüência de sintomas de

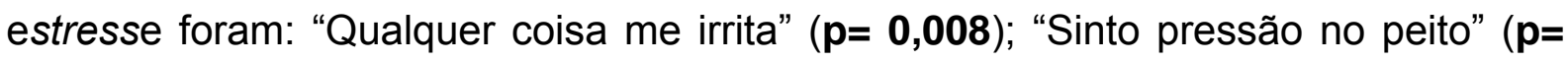
$\mathbf{0 , 0 0 8 ) ; ~ " S i n t o ~ q u e ~ m e u ~ d e s e m p e n h o ~ e s t a ́ ~ l i m i t a d o ~ n o ~ t r a b a l h o " ~}(\mathbf{p}=\mathbf{0 , 0 0 0})$; e o item "Tenho um nó no estômago" ( $\mathbf{p =} \mathbf{0 , 0 0 8 )}$; conforme oscilação dos dados demonstrados pelas FIGURAS 34, 35, 36 e 37.

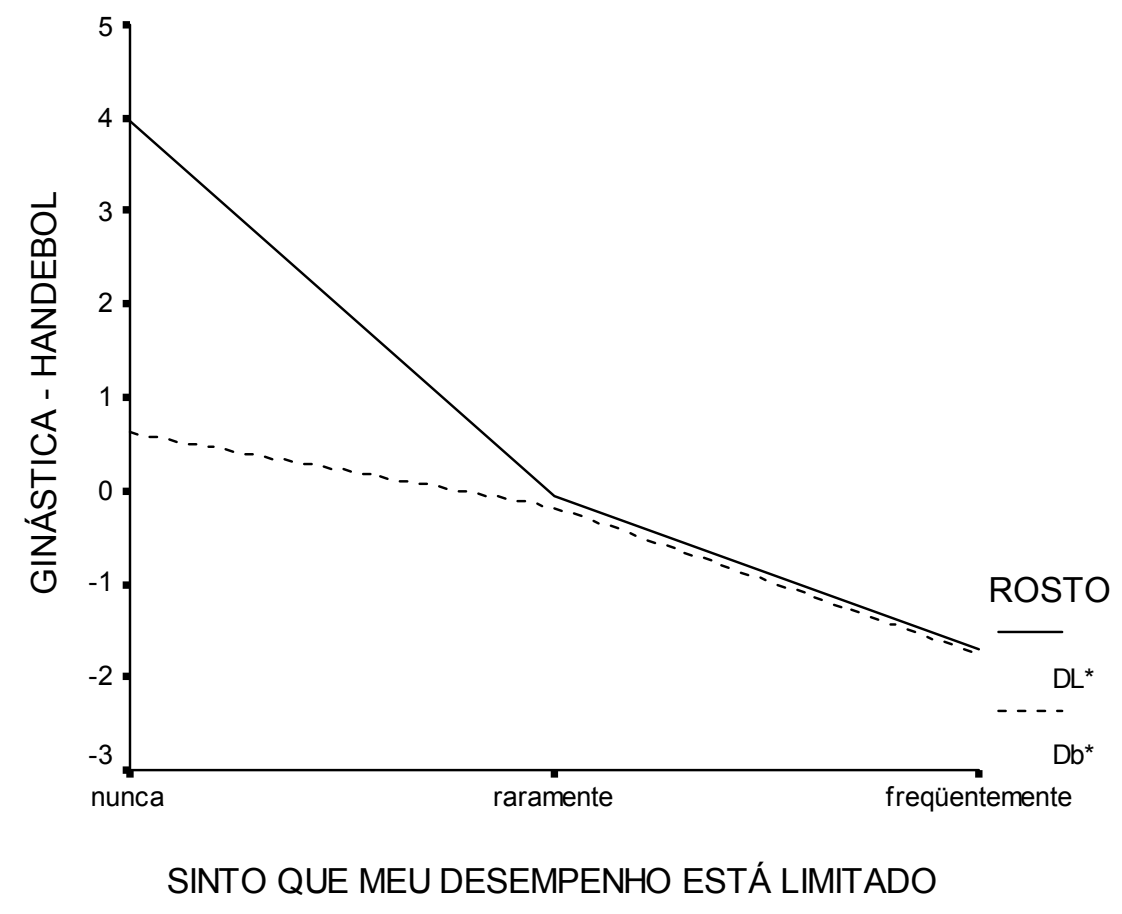

FIGURA 34 - Associação entre freqüência do sentimento de desempenho limitado e oscilação DL*no rosto dos atletas da Ginástica Artística e Handebol 


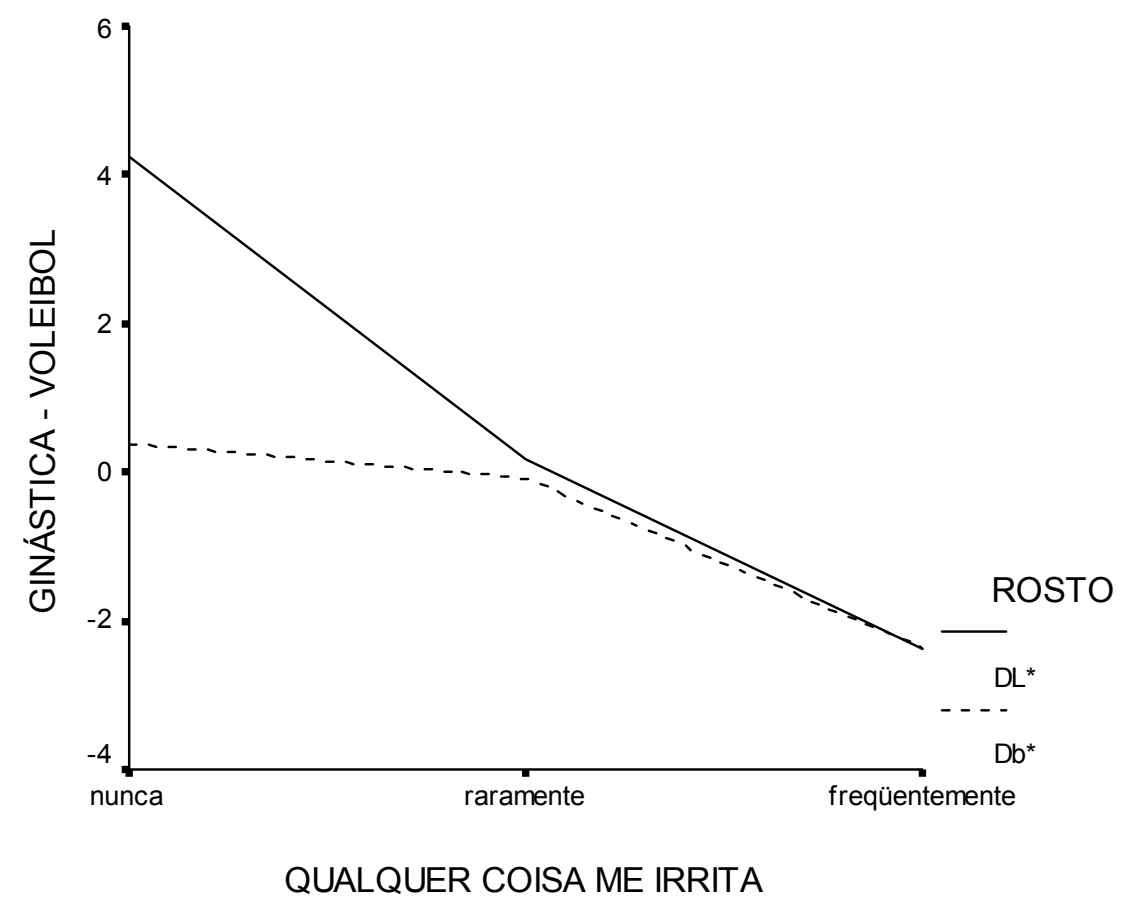

FIGURA 35 - Associação entre freqüência do sentimento de irritação e oscilação DL*no rosto dos atletas da Ginástica Artística e Handebol

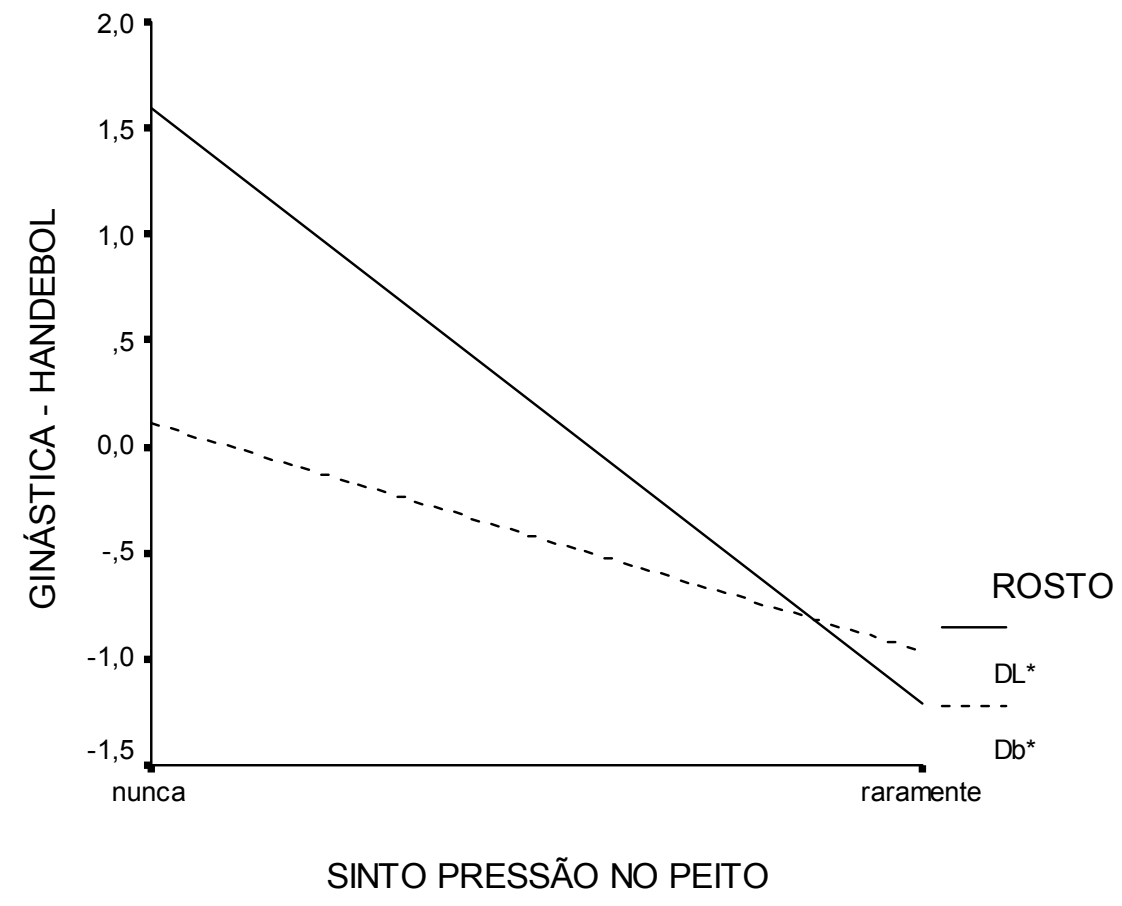

FIGURA 36 - Associação entre freqüência do sentimento de pressão no peito e oscilação DL*no rosto dos atletas da Ginástica Artística e Handebol 


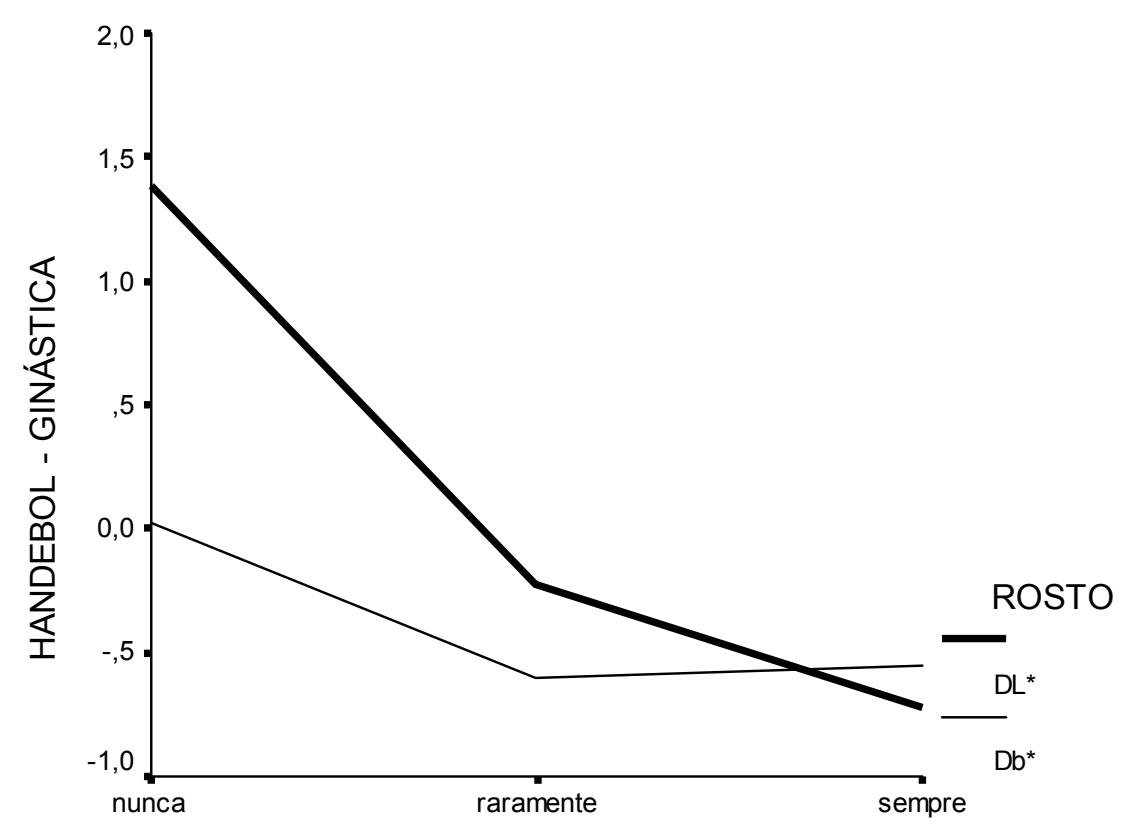

TENHO UM NÓ NO ESTOMAGO

FIGURA 37 - Associação entre freqüência da sensação de nó no estômago e oscilação DL*no rosto dos atletas da Ginástica Artística e Handebol

As FIGURAS 34, 35, 36 e 37 mostram as correlações mais fortes dos itens da LSS-VAS: "Sinto que meu desempenho está limitado no trabalho" $(\mathbf{p}=\mathbf{0 , 0 0 0})$;

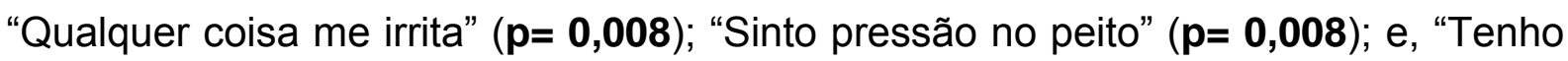

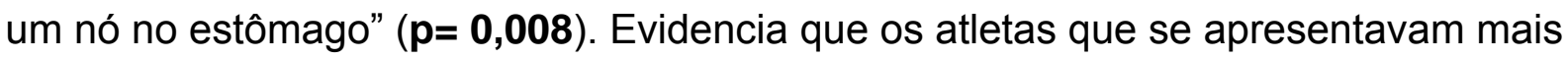
pálidos no rosto "amarelão" antes do início dos treinos, mostraram que, com maior freqüência, sentiam o desempenho limitado no trabalho; irritação; pressão no peito e nó no estômago.

As características gerais da associação entre a freqüência de sintomas de estresse e a oscilação da cor da pele $\mathrm{DL}^{*}$ (claro - escuro) dos atletas da Ginástica Artística e Handebol, que constituíram o grupo dos atletas experientes no esporte de alto rendimento e caracterizou-se como fase de resistência ao estresse NITSCH, ALLMER, HACKFORT, LAZARUS, MCGRATH, SELYE e UDRIS (1981).

Até este ponto, os dados obtidos sobre a oscilação espectral da cor da pele $D L^{*}$ (claro-escuro) pelo somatório da freqüência de sintomas de estresse dos atletas 
de ginástica e Handebol são favoráveis às hipóteses de pesquisa da relação entre o "amarelão" e os sintomas de estresse. A seguir, os dados sobre as variações espectrofotométricas das oscilações da cor da pele e sintomas de estresse no eixo $\mathrm{Db}^{*}$ (azul-amarelo) são analisados.

\subsubsection{Associação da oscilação espectral da cor da pele no braço dos atletas} da Ginástica Artística, Handebol e Voleibol e a freqüência do sentimento de medo

A análise do coeficiente de Spearman pelos itens da LSS-VAS mostrou altíssima correlação com o item "Tenho medo" com a oscilação espectral da cor da

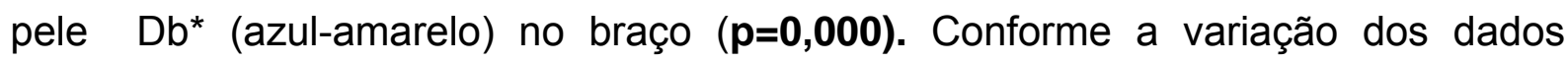
destacados pela FIGURA 38.

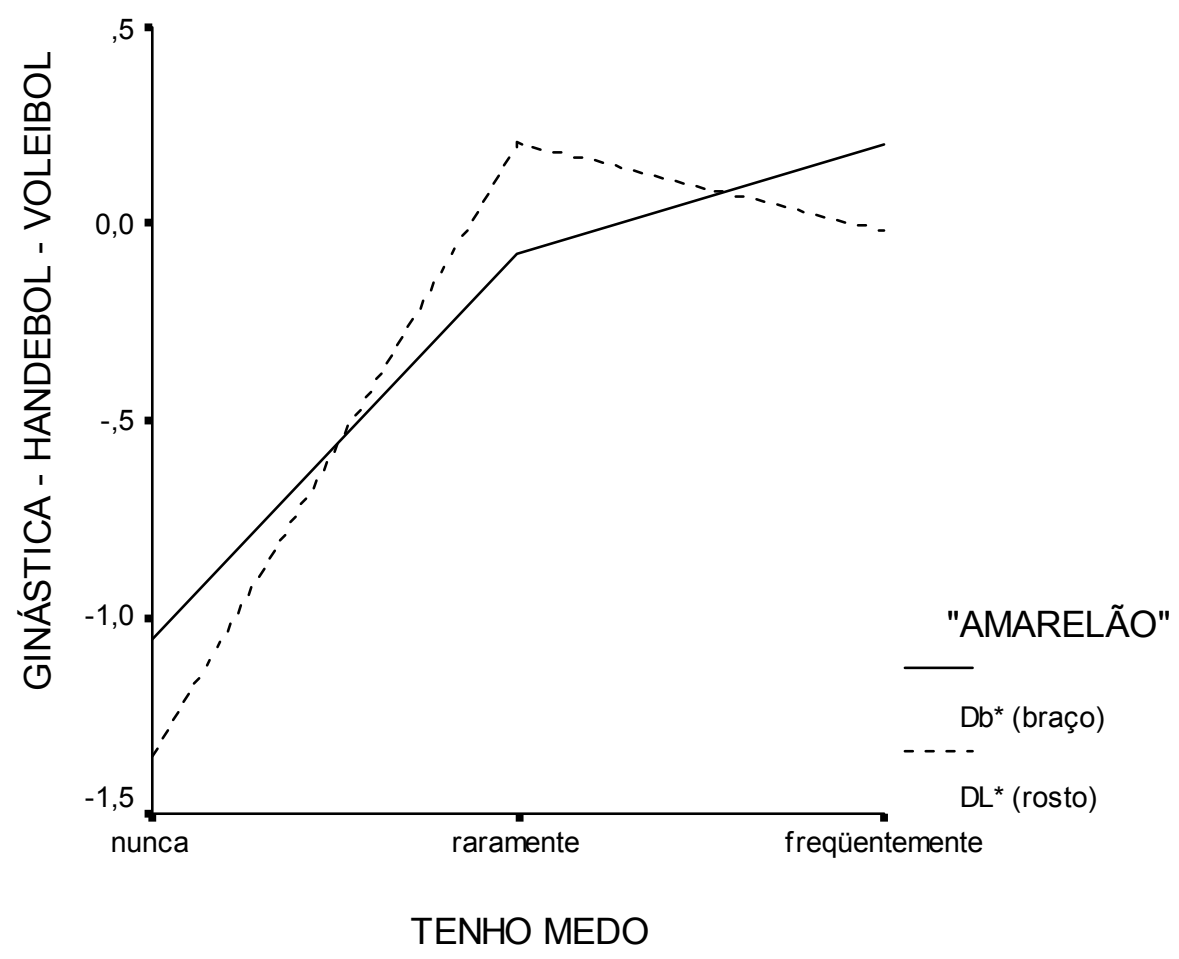

FIGURA 38 - Associação entre freqüência do sentimento de medo e oscilação Db* no rosto dos atletas da Ginástica Artística, Handebol e Voleibol 
A FIGURA 38 mostra que a oscilação da cor da pele Db* (azul-amarelo) no braço; $\mathrm{DL}^{*}$ (claro-escuro) no rosto e o sentimento de medo entre os atletas do Handebol, Voleibol e Ginástica Artística, revelou a mesma tendência de oscilação entre os atletas iniciantes e experientes. Os atletas que assinalaram nunca sentir medo apresentaram a cor da pele significativamente menos amarelada e menos pálida depois do jogo, em relação aos que mostraram sentir medo.

\subsubsection{Associação da oscilação espectral da cor da pele do braço dos atletas} da Ginástica Artística, Handebol e Voleibol e a freqüência do sentimento de pavor

O item LSS-VAS "Qualquer coisa me apavora" apresentou alta correlação com a oscilação espectral da cor da pele $\mathrm{Db}^{*}$ (azul-amarelo) no braço $(\mathbf{p}=\mathbf{0 , 0 0 1})$ dos atletas da Ginástica Artística, Handebol e Voleibol e o sentimento de pavor, conforme a variação dos dados destacados pelas FIGURAS 39.

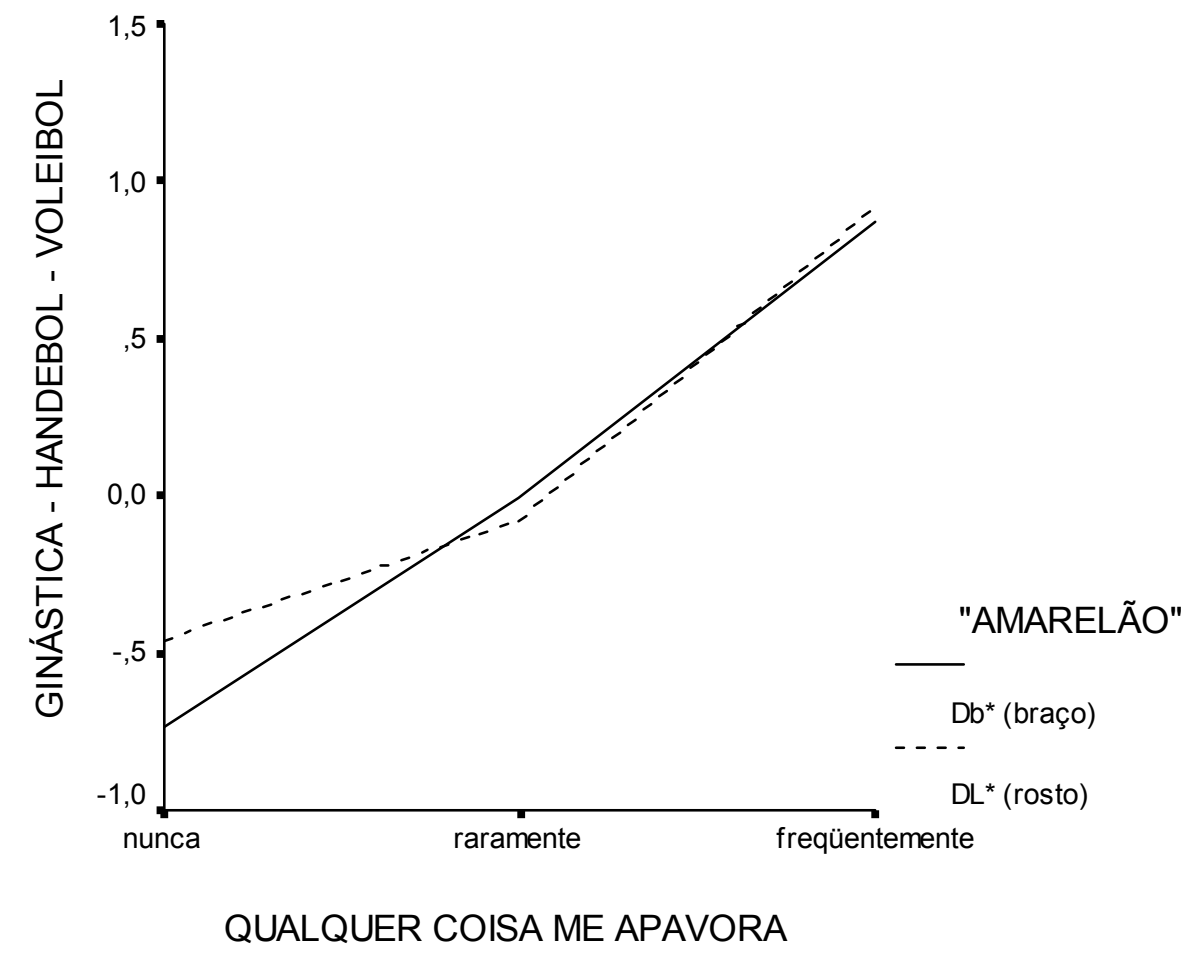

FIGURA 39 - Associação entre freqüência do sentimento de pavor e oscilação Db* no rosto dos atletas da Ginástica Artística, Handebol e Voleibol 
A FIGURA 39 mostra que a oscilação da cor da pele Db* (azul-amarelo) no braço; $\mathrm{DL}^{*}$ (claro-escuro) no rosto e o sentimento de pavor entre os atletas do Handebol, Voleibol e Ginástica Artística, revelou a mesma tendência de oscilação entre os atletas iniciantes e experientes. Os atletas que assinalaram nunca sentir pavor apresentaram a cor da pele significativamente menos amarelada e menos pálida depois do jogo, em relação aos que mostraram sentir pavor.

A oscilação espectral da cor da pele $\mathrm{DL}^{*}$ (claro-escuro) nas medições no rosto e $\mathrm{Db}^{*}$ (azul-amarelo) nas medições do braço e a freqüência de sintomas de estresse dos atletas da Ginástica Artística, Handebol e Voleibol é favorável às hipóteses de pesquisa da relação entre o "amarelão" e sintomas de estresse. A seguir, são analisados os dados sobre a intensidade dos sintomas de estresse e as variações espectrofotométricas das oscilações da cor da pele.

\subsubsection{Análise da oscilação espectral da cor da pele no braço e no rosto dos atletas da Ginástica Artística, Handebol e Voleibol e a intensidade dos sintomas de estresse (LSS-VAS)}

A análise pelo coeficiente de correlações Spearman dos dados obtidos sobre a intensidade dos sintomas de estresse LSS-VAS e das diferenças de cor da pele no braço e no rosto por meio dos valores espectrais $\mathrm{DL}^{*}, \mathrm{Da}^{*}$ e $\mathrm{Db}^{*}$ mostrou os seguintes resultados: $\mathrm{DL}^{*}$ (braço: $\mathrm{p}_{23}=0,670 ; \mathrm{p}_{59}=0,779$ - rosto: $\mathrm{p}_{23}=0,186, \mathrm{p}_{59}$ $=0,074$ ); Da* $^{*}$ (braço: $p_{23}=0,729 ; p_{59}=0,599$ - rosto: $p_{23}=0,592, p_{59}=0,841$ ), e $\mathrm{Db}^{*}$ (braço: $\mathbf{p}_{23}=\mathbf{0 , 0 4 6} ; \mathbf{p}_{59}=\mathbf{0 , 0 4 0}$ - rosto: $\mathbf{p}_{23}=0,963 p_{59}=0,653$ ).

Assim, houve uma correlação significativa entre a oscilação da cor da pele no braço $\mathrm{Db}^{*}$ (azul-amarelo) e o somatório da intensidade dos 23 primeiros itens da LSS-VAS: valores referentes à intensidade do estresse dos atletas da Ginástica Artística e Handebol. Mostrou também correlação significativa entre a oscilação da cor da pele no braço $\mathrm{Db}^{*}$ e o somatório da intensidade total dos 59 itens de LSSVAS, conforme dados destacados pela FIGURA 40. 


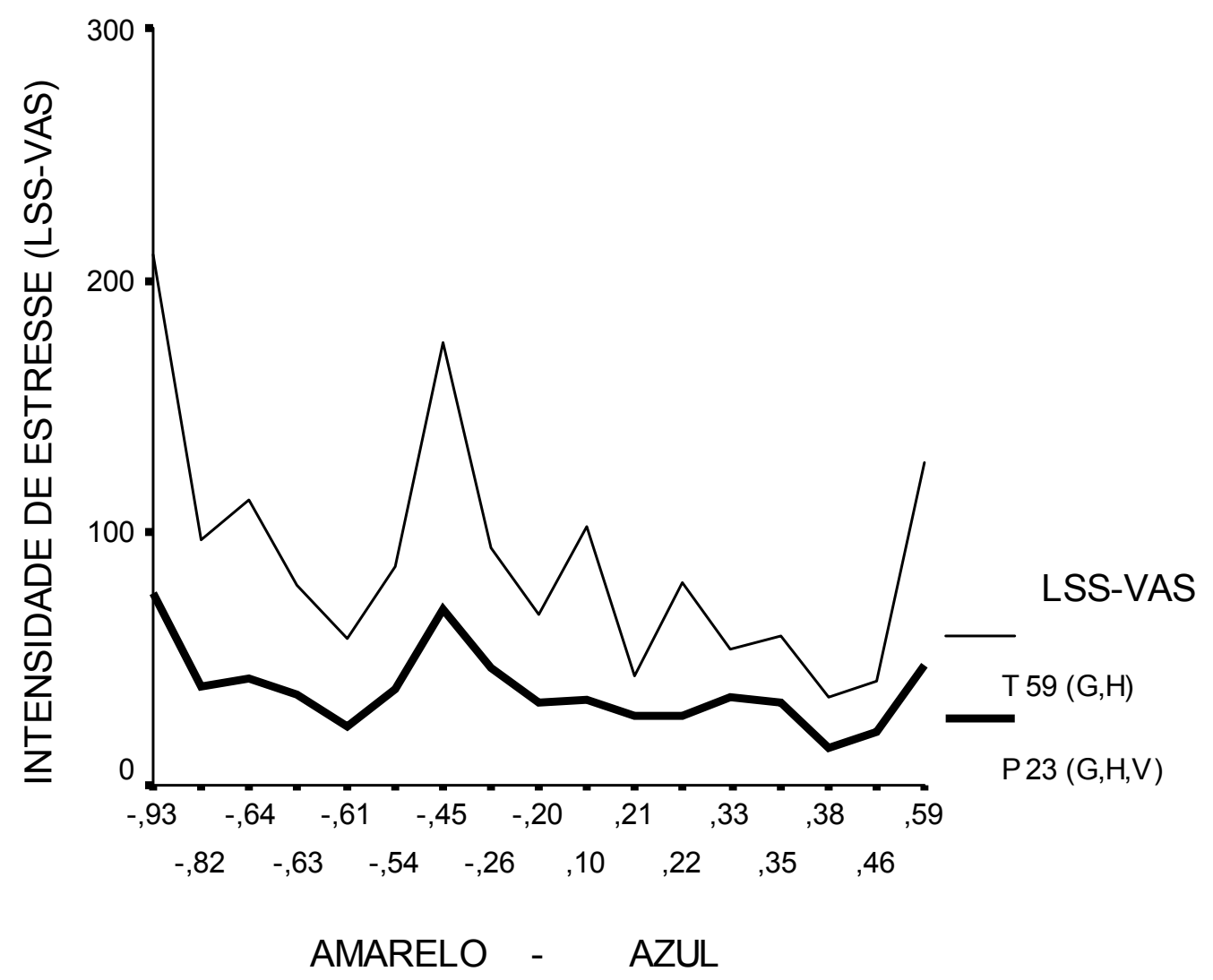

FIGURA 40 - Associação da intensidade de sintomas de estresse e oscilação espectral $\mathrm{Db}^{*}$ no braço dos atletas da Ginástica Artística e Handebol

A FIGURA 40 mostra a tendência dos escores mais elevados de intensidade dos sintomas de estresse que se associaram aos valores mais negativos de $\mathrm{Db}^{*}$. Os atletas com maior intensidade de sintomas de estresse tinham a cor da pele significativamente mais amarelada antes dos treinos.

Os itens LSS-VAS com as mais fortes correlações $(p<0,02)$ com a oscilação espectral Db, foram: "Ranjo os dentes" (Ginástica Artística, Handebol e Voleibol p= $\mathbf{0 , 0 0 9 ) ; ~ " T e n h o ~ d o r e s ~ n a s ~ c o s t a s " ~ ( G i n a ́ s t i c a ~ A r t i ́ s t i c a , ~ H a n d e b o l ~ e ~ V o l e i b o l ~ p = ~ 0 , 0 0 7 ) ; ~}$ "Fumo demais" (Ginástica Artística e Handebol p= $\mathbf{0 , 0 0 2}$ ); "Sinto pressão no peito" (Ginástica Artística e Handebol $\mathbf{p}=\mathbf{0 , 0 0 3}$ ); "Tenho um nó no estômago" (Ginástica Artística e Handebol $\mathbf{p}=\mathbf{0 , 0 1 0}$ ); "Tenho dúvidas sobre mim mesmo" (Ginástica

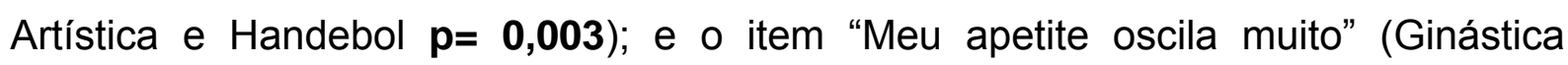

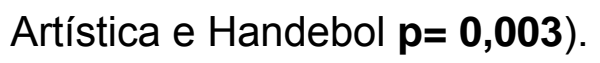




\subsubsection{Oscilação espectral da cor da pele $\mathrm{DL}^{*}$ (claro-escuro) rosto e o coping pela crença da ajuda de Deus para vencer obstáculos no esporte}

A análise pelo coeficiente de correlação de Spearman mostrou correlação significativa $(p=0,013)$, entre a questão do IPCRE "Você acredita que Deus poderia ajudar a vencer obstáculos no esporte" e a oscilação da cor da pele DL* (rosto), que apresentou correlação significativa forte com a freqüência dos itens: "Qualquer coisa me irrita" ( $p=0,008)$; "Sinto pressão no peito" $(p=0,008)$; "Sinto que meu desempenho está limitado no trabalho" $(\mathbf{p}=\mathbf{0}, \mathbf{0 0 0})$; e, "Tenho um nó no estômago" $(p=0,008)$, conforme a FIGURA 41.

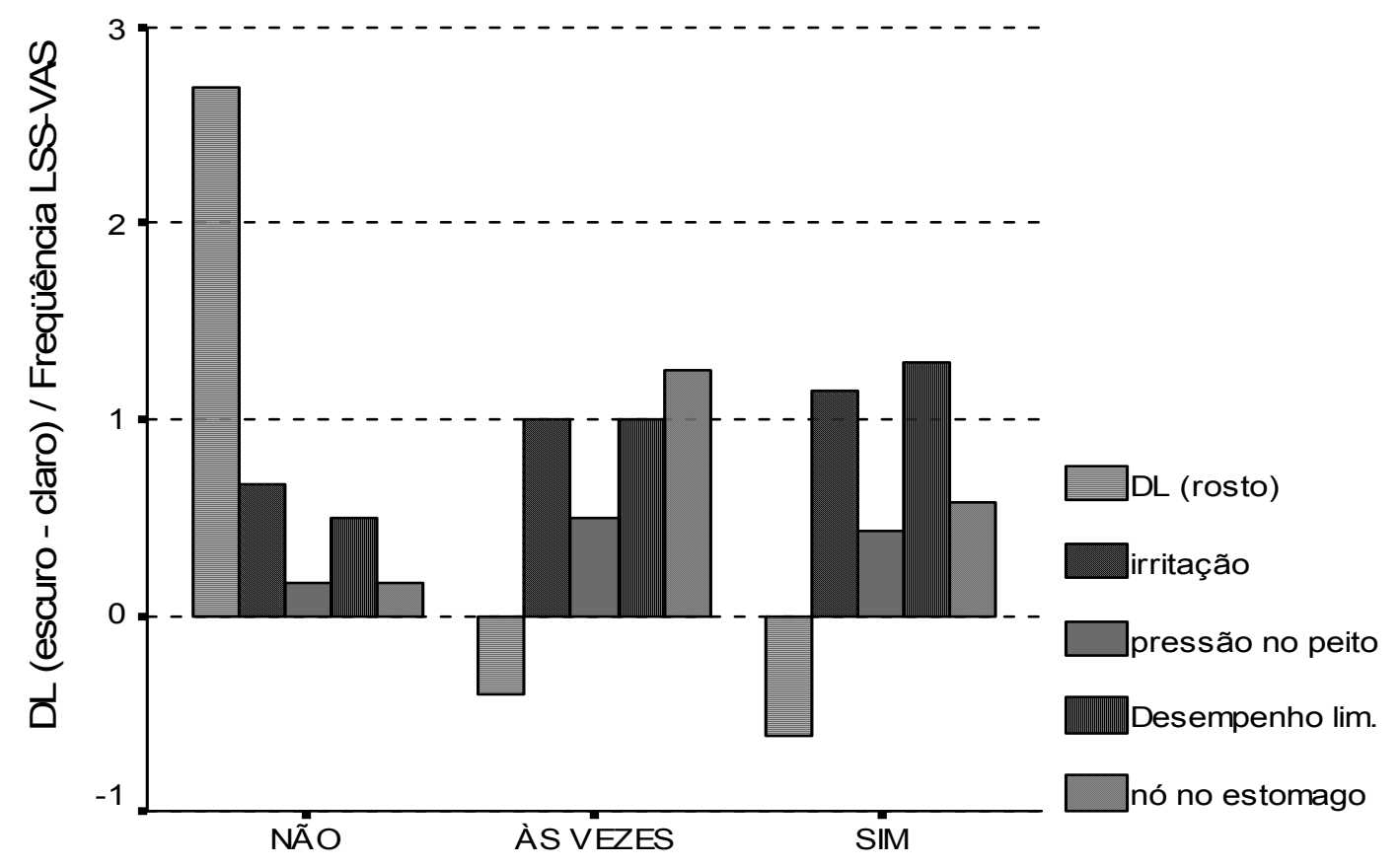

Você acredita que Deus poderia ajudar vencer...

FIGURA 41 - Associação da oscilação espectral $\mathrm{DL}^{*}$ no rosto dos atletas da Ginástica Artística e Handebol, Freqüência de sintomas de estresse e coping pela crença em Deus como ajuda para superar obstáculos 
Os dados da FIGURA 41 mostram que os atletas da Ginástica Artística e do Handebol (fase de resistência) que afirmaram acreditar (sim - 39\%) que Deus poderia ajudar a vencer obstáculos no esporte, foram os que apresentavam a cor da pele significativamente mais clara (amarelão) nas medições antes do início dos treinos mostraram maiores limitações no desempenho e irritação. A complementação desses dados pelas informações obtidas dos atletas na questão da percepção de Deus, como ajuda para superar obstáculos no esporte, pode ajudar a elucidar algumas das características do coping pelas crenças religiosas e sintomas de estresse, conforme os seguintes dados:

SIM (39\%): "Acredito que Deus dá um equilíbrio e auxilia o atleta, dando força e esperança para que nunca desista e enfrente os obstáculos"; "Por causa dessa energia presente, mas partindo do princípio, nesse caso, da força de dentro para fora"; "Ele pode nos ajudar encontrar respostas e caminhos que, às vezes, não encontramos sozinhos, além de nos motivar nos momentos em que não estamos tão felizes"; "Com certeza - principalmente, por nos sentirmos protegidos e motivados para superar nosso limite"; "Eu acredito porque quando eu tenho medo de fazer um exercício, eu sempre peço a ajuda Dele e me sinto mais confiante com isso"; "Depende de sua crença"; "Não diretamente como fazer o pedido de ganhar um campeonato, mas para que você enfrente e continue no dia-a-dia treinando e seguindo, ultrapassando obstáculos".

A complementação das respostas dos atletas da Ginástica Artística e Handebol, sobre a interferência de Deus como ajuda para superar obstáculos no esporte, deixa transparecer aquilo que FREUD (1927) define como ilusão. Os atletas revelam por meio de seus relatos aquilo que buscam e vivenciavam: motivação, proteção, equilíbrio, força para não desistir e medo. Dificuldades que se impregnavam no psiquismo e no organismo dos atletas, ao ponto de se revelarem pela maior palidez ou o amarelão no senso comum, antes do início dos treinos em relação aos atletas que disseram não acreditar que Deus poderia ajudar vencer obstáculos no esporte, conforme os seguintes dados:

NÃO (39\%): "Deus não nos ajuda a vencer nada, Deus apenas nos dá a oportunidade de vencer um medo, um desafio como uma competição. Só nós mesmos para acreditar que somos capazes, pois Deus sempre acredita em nosso 
potencial"; "Tudo depende de talento, trabalho e dedicação, quando o assunto é esporte competitivo"; "Ele te dá condição para estar bem equilibrado para o treinamento e competição, conseqüentemente, vitória"; "Acredito que Deus gostaria que todos obtivessem a vitória, e não um com alegria e o outro com tristeza. Acredito que esta seja nossa profissão e, se trabalharmos muito obtemos nosso resultado. Porque Deus deixou para o homem receber o fruto de seu trabalho, e isso é uma bênção"; "No esporte, acho que se você fizer mais do que os outros, você consegue mais objetivos positivos que os outros. Acho que ajuda na hora de uma lesão"; "a coisa que peço é para não me machucar, o resto é nós que fazemos"; "acho que diretamente não, uma influência que pode ajudar".

Os atletas que não acreditam na interferência de Deus no esporte, apesar da ambigüidade de determinados posicionamentos, denotam que o coping com foco no problema denota sentimentos de maior confiança. Declaram obter as vitórias por seus próprios esforços, sem problemas com lesões, apesar do medo explicito. Revelaram sentimentos de maior confiança, que se impregnavam no psiquismo e no organismo dos atletas a ponto de ter sido possível detectar pelas mensurações espectrofotométricas da cor da pele no rosto, menor palidez em relação àqueles que buscam o coping pela crença na ajuda de Deus.

No esporte, o inventario Pratt de crenças religiosas procura aprofundar a investigação e os desdobramentos do posicionamento dos atletas na questão sobre a interferência de Deus, como ajuda para superar obstáculos no esporte. Complementa a questão com informações sobre a interferência de Deus nas derrotas: "e nas derrotas, Deus teria alguma participação". Esta questão também mostrou correlação significativa $(p=0,024)$ com a oscilação da cor da pele $D^{*}$ * (rosto)" , conforme a FIGURA 42. 


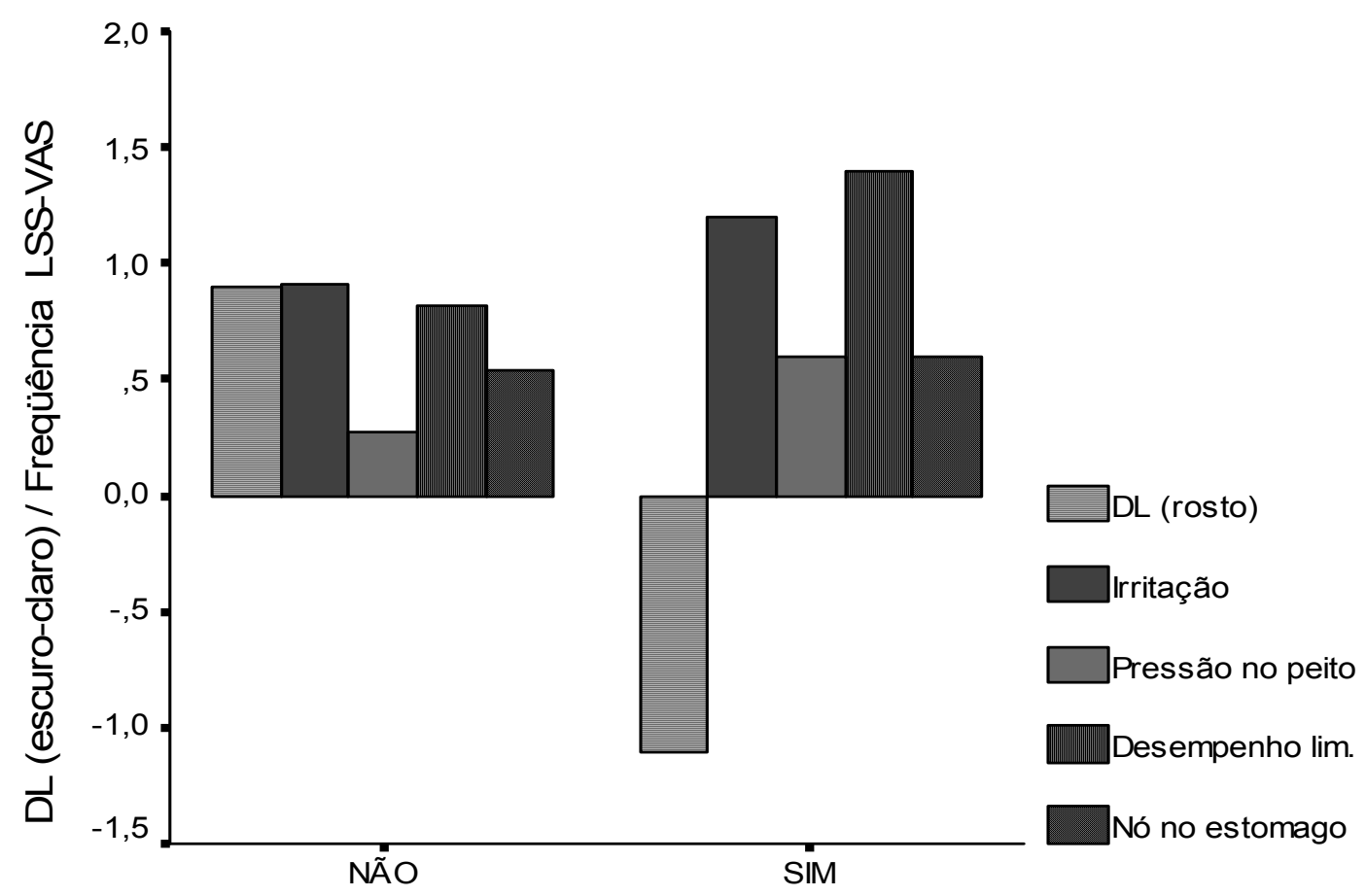

E nas derrotas, Deus teria alguma participação?

FIGURA 42 - Associação da oscilação espectral DL*rosto dos atletas da Ginástica Artística e Handebol, freqüência de sintomas de estresse e coping pela crença da interferência de Deus nas derrotas

Os dados da FIGURA 43 mostram que os atletas (22\%) que acreditavam na interferência de Deus nas derrotas, apresentavam a cor da pele significativamente mais clara no rosto (amarelão - antes dos treinos), mostraram maior limitação no desempenho, em relação aos atletas que não acreditam na interferência de Deus nas derrotas. Aqueles que assinalaram a alternativa: às vezes, na questão sobre a interferência de Deus como ajuda para superar obstáculos no esporte, mudaram de posicionamento para não, evidenciando que acreditam na interferência de Deus apenas em relação a aspectos positivos. Os dados obtidos dos atletas pela complementação da questão sobre a interferência de Deus nas derrotas deixam transparecer pelas vicissitudes do esporte de alto rendimento, os aspectos do sentimento religioso referidos como ilusão (FREUD, 1927). 
SIM (39\%): "A derrota ensina muito mais do que a vitória, porém o mais importante é honrar Deus, fazendo o melhor que você pode e não vencer. Ter a consciência de que se esforçou ao máximo e que Deus estava com você - isso basta para que se tenha alegria mesmo na derrota"; "Não que Ele seja responsável pela derrota, mas ele pode nos ajudar a superar o momento de dificuldade e enxergar os erros que cometemos"; "Fazendo nos perceber que nossa garra e luta não foi o suficiente. Ele nos ensina a aprender com os próprios erros"; "Depende de sua crença"; "Ele nos traz experiências de felicidade e momentos de aprendizado e a derrota no esporte, muitas vezes, vem para aprendermos alguma coisa".

Os dados obtidos dos atletas da Ginástica Artística e Handebol sobre a interferência da ajuda de Deus revelam nitidamente que passam por momentos de sofrimento e dor que se refletiu na palidez do rosto $\left(-D L^{*}\right)$. Ao mesmo tempo, esses atletas deixam transparecer que tudo aquilo de negativo que vivenciavam, poderia transformar-se em algo positivo por meio de um aprendizado com as derrotas. Resultado que coloca em perspectiva a complexidade do coping oferecido pela crença da interferência de Deus nas derrotas.

NÃO (72\%) - "Não vejo essa relação de vitória / derrota, e sim bem estar físico e mental para o treinamento"; "Se Deus interferisse nunca teríamos um vencedor”; “...relaciono Deus com coisas boas, e vencer obstáculos é uma coisa boa"; "Quem atua somos nós"; "As derrotas fazem parte da vida terrestre, no jogo sempre haverá um perdedor"; "na derrota a culpa é só do grupo"; "Pois foi um merecimento do outro que ganhou, pois não se pode ganhar sempre"; Ele não têm nada a ver com nossos derrotas, nós que temos que lutar para conseguir".

O posicionamento dos atletas que não acreditam na interferência de Deus nas derrotas, reafirma os sentimentos de maior confiança e menor estresse, pois estavam menos pálidos em relação aos que se posicionaram afirmativamente.

As percepções dos atletas sobre as crenças religiosas alinham-se às concepções estabelecidas por PAIVA (1998), PORTNOI (1999) caracterizadas como estratégias de coping ao stress provocado pela doença e a dor. Inferindo-se que a busca de Deus para vencer obstáculos no esporte tem um sentido utilitarista, oferece um coping ineficiente, pois está relacionado com as limitações do desempenho dos atletas, maior irritação e sensação de pressão no peito. 


\subsubsection{Análise do lócus de controle, oscilação da cor da pele e sintomas de estresse de atletas da Ginástica Artística, Handebol e Voleibol}

A análise pela busca do esclarecimento das hipóteses das variações da cor da pele nas dimensões do espaço $\mathrm{CIE} L^{*} a^{*} b^{*} e$ as dimensões do lócus de controle: interno (LCl), externo sorte-azar (LCE-AS) e pessoas poderosas (LCE PP). As correlações entre essas variáveis resultaram - DL* claro-escuro: Lócus de controle interno ( $p_{\text {braço }}=0,381, p_{\text {rosto }} 0,209$ ); Lócus de controle externo sorte-azar ( $p_{\text {braço }}=0,744$, prosto 0,363 ); Lócus de controle externo pessoas poderosas ( $p_{\text {braço }}=0,317$, p prosto 0,107 ). Da* vermelho-verde: Lócus de controle interno ( $p_{\text {braço }}=0,202$, p prosto 0,241 ); Lócus de controle externo sorte-azar ( $p_{\text {braço }}=0,704, p_{\text {rosto }} 0,799$ ); Lócus de controle externo pessoas poderosas ( $p_{\text {braço }}=0,742, p_{\text {rosto }} 0,383$ ). $\mathrm{Db}^{*}$ azul - amarelo: Lócus de controle interno ( $p_{\text {braço }}=0,803$, $p_{\text {rosto }} 0,174$ ); Lócus de controle externo sorte-azar $\left(p_{\text {braço }}=0,189\right.$, $\left.p_{\text {rosto }} 0,192\right)$; Lócus de controle externo pessoas poderosas $\left(p_{\text {braço }}=0,139\right.$, p prosto 0,180$)$.

Pela análise do coeficiente de correlações de Spearman, não houve correlação significativa entre a oscilação da cor da pele nas dimensões espectrais do espaço CIE $L a^{*}$ b e o lócus de controle: interno ( $L C l$ ) e externo - sorte-azar (LCE-AS), pessoas poderosas (LCE-PP). Os resultados confirmam os dados encontrados nas análises parciais dos grupos que colocam em perspectiva uma das características estruturais do conceito do lócus de controle, concebida no contexto da teoria da aprendizagem social, como um indicador geral do comportamento futuro. Na Escala Multidimensional de Lócus de Controle do Esporte, apareceu como norteador das características gerais dos acontecimentos futuros na carreira esportiva. 


\subsubsection{Análise das correlações entre lócus do controle e sintomas de estresse dos atletas da Ginástica Artística, Handebol e Voleibol}

O estudo dos dados obtidos sobre lócus de controle, freqüência e intensidade de sintomas de estresse é apresentado nos dados da TABELA 12

TABELA 12 - Análise de correlação da freqüência e intensidade dos sintomas do estresse e o lócus de controle dos atletas da Ginástica Artística, Handebol e Voleibol

\begin{tabular}{llrrr}
\hline \hline & & L C I L C E - S A & L C E - P P \\
\hline LSS-VAS (freqüência) & coeficiente & 0,216 &,- 129 &, 154 \\
23 itens & sigificância & 0,270 &, 512 &, 433 \\
& $\mathrm{~N}$ & 2 & 28 & 28 \\
\hline & coeficiente & $0,05 C$ &, 158 &, 109 \\
& sigificância & 0,853 &, 558 &, 687 \\
59 itens & $\mathrm{N}$ & 1 & 16 & 16 \\
& coeficiente & 0,372 &,- 240 &,- 248 \\
& sigificância & 0,156 &, 370 &, 355 \\
& $\mathrm{~N}$ & 1 & 16 & 16 \\
\hline LSS-VAS (intensidade) & & 16 & 16 \\
& &
\end{tabular}

A TABELA 12 mostra que não houve correlação significativa entre lócus de controle, freqüência e intensidade de sintomas de estresse. Mas ao se aprofundar a análise, verificamos uma correlação significativa entre o Lócus de controle interno e a freqüência de três itens da LSS-VAS: "Rôo unhas" ( $p=0,021$ - Ginástica Artística, Handebol e Voleibol); "Sinto insegurança" ( $p=0,016$ - Ginástica Artística, Handebol); e o item "Tenho vontade de ficar sozinho" ( $p=0,030$ - Ginástica Artística, Handebol). O tipo de correlação entre Lócus de controle interno e a freqüência dos itens com correlação significativa é destacado pelos dados das FIGURAS 43, 44 e 45. 


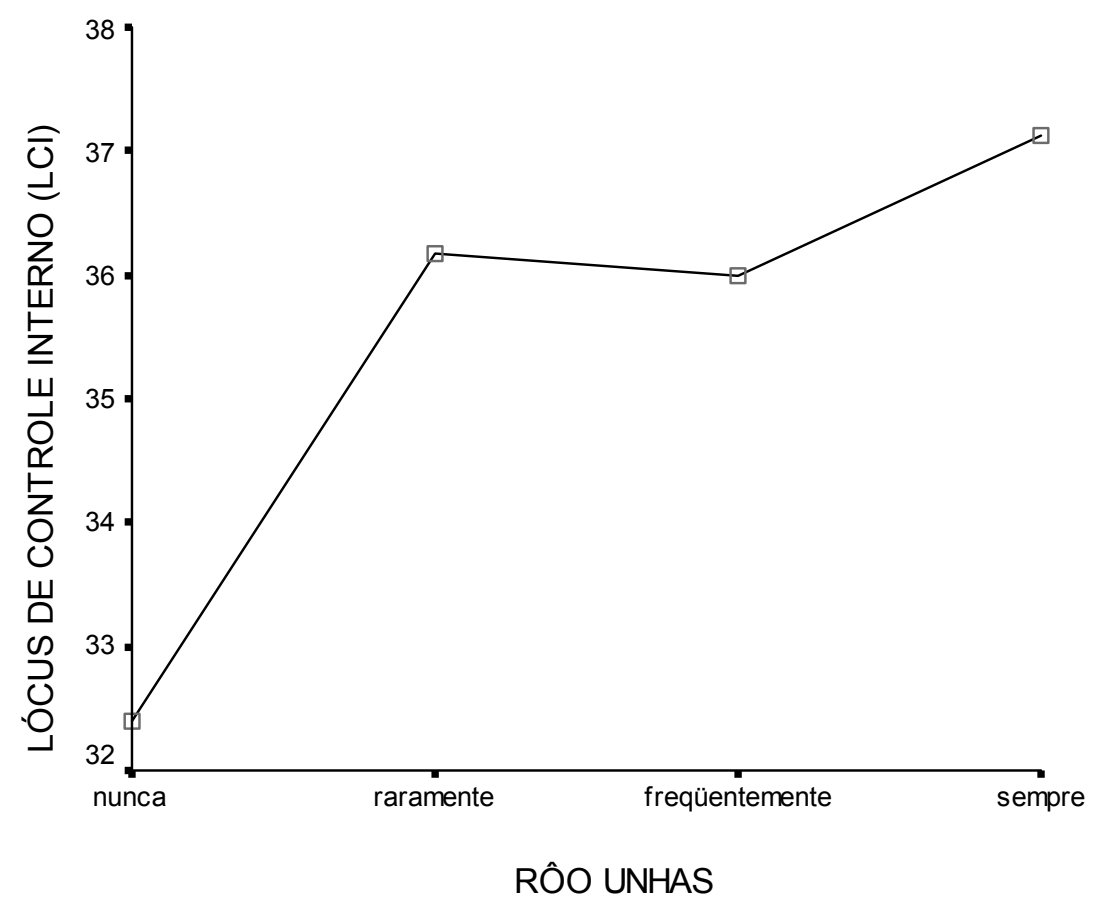

FIGURA 43 - Associação do lócus de controle interno e compulsão dos atletas da Ginástica Artística, Handebol e Voleibol roerem as unhas

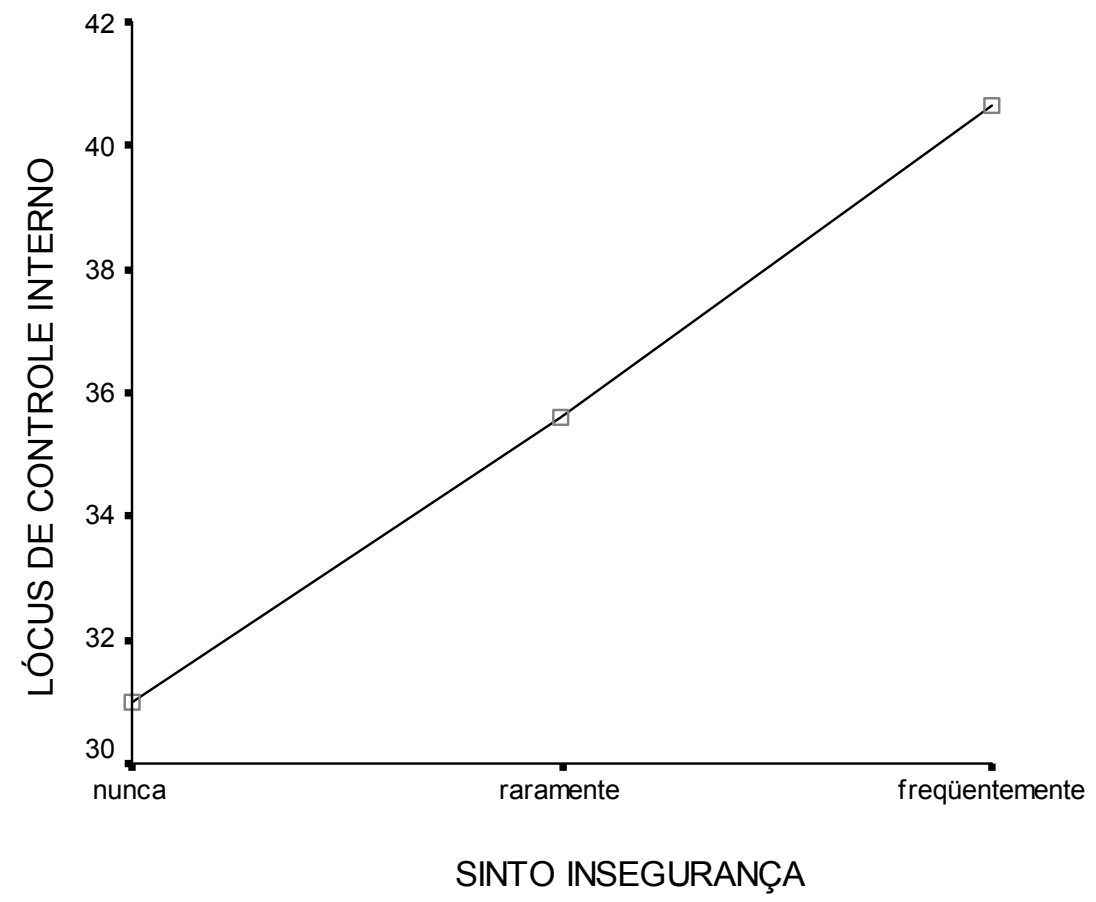

FIGURA 44 - Associação do lócus de controle interno e sentimentos de insegurança dos atletas da Ginástica Artística, Handebol e Voleibol 


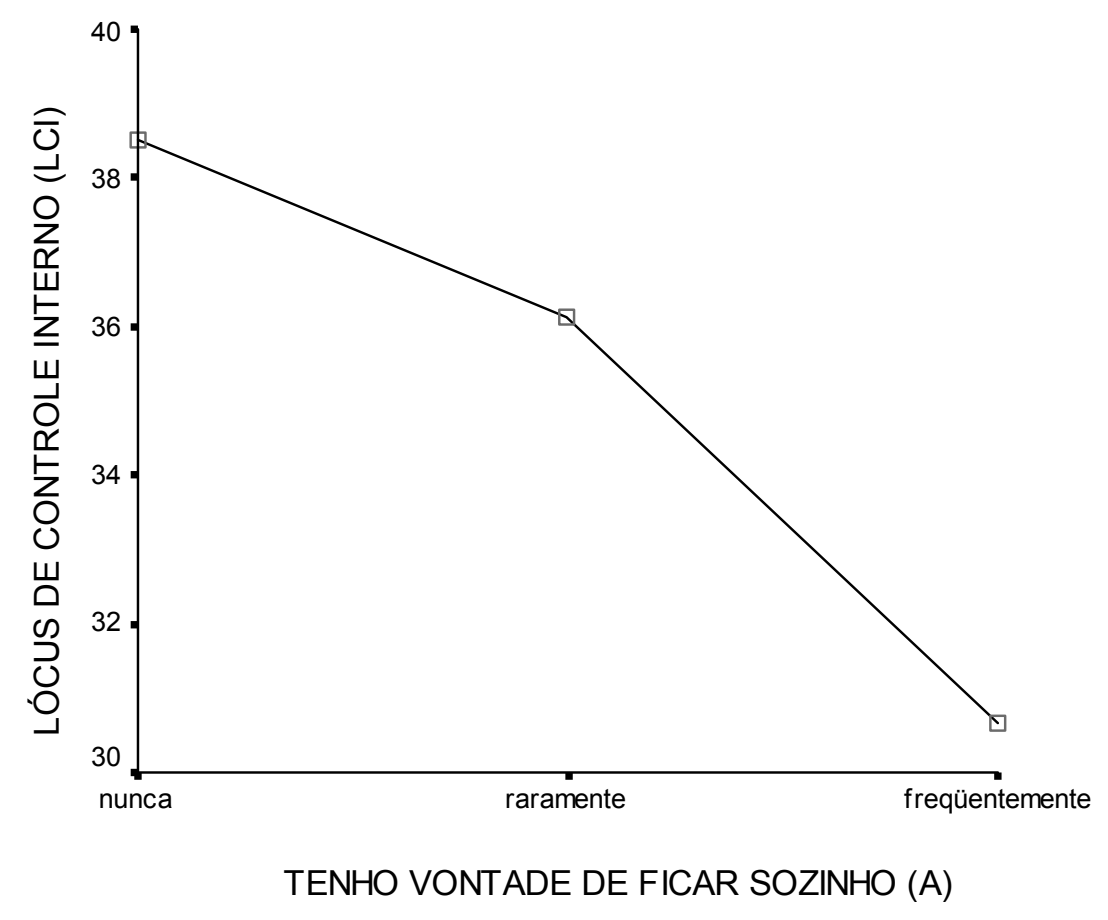

FIGURA 45 - Associação do lócus de controle interno e vontade de ficar sozinho dos atletas da Ginástica Artística, Handebol e Voleibol

As FIGURAS 43, 44 e 45 mostram os atletas que apresentaram os maiores escores de lócus de controle interno que revelaram roer as unhas com maior freqüência $(p=0,021)$, sentem-se mais inseguros $(p=0,016)$ e, com menor freqüência têm vontade de isolar-se $(p=0,030)$. Infere-se que as expectativas do lócus de controle interno, diante de uma situação que possui por implícito alta seletividade e certo grau de aleatoriedade, implicam sentimentos de maior estresse pelo sentimento de insegurança, dai a disposição dos atletas em não separarem-se do grupo.

A análise da possível associação entre o lócus de controle externo sorte azar e a freqüência de sintomas de estresse revelou uma correlação significativa com o

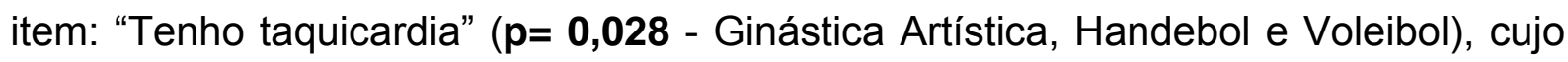
tipo de correlação é evidenciada pela FIGURA 46 


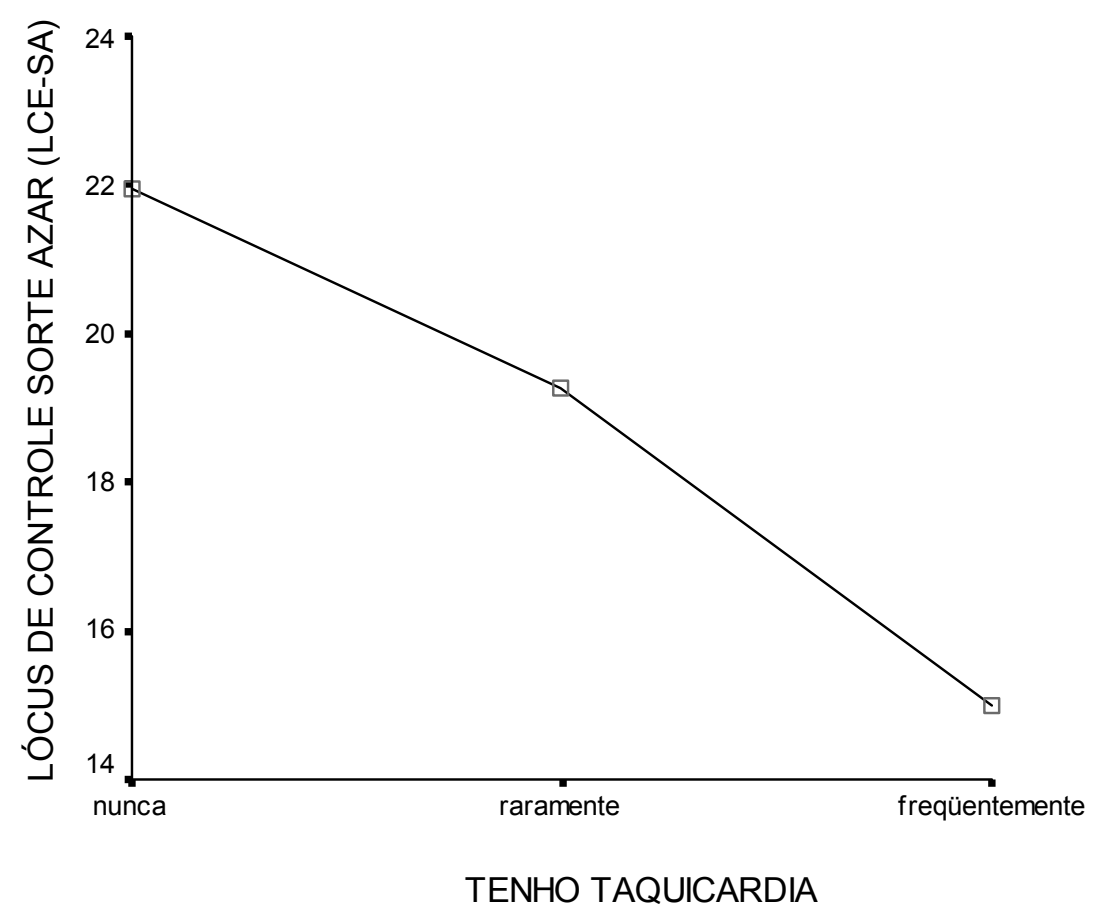

FIGURA 46 - Associação do lócus de controle externo sorte-azar e sensação de aumento dos batimentos cardíacos dos atletas da Ginástica Artística, Handebol e Voleibol

A FIGURA 46 mostra a relação dos atletas com maiores índices de lócus de controle externo sorte-azar com os que assinalaram nunca sentir taquicardia, ou seja, aqueles que creditam o lócus do controle dos acontecimentos na carreira esportiva à interferência da sorte ou azar, demonstraram ter menor estresse físico e emocional, evidenciado por palpitações e aceleração dos batimentos cardíacos. Já os atletas da Ginástica Artística, Handebol e Voleibol, que apresentaram índices mais baixos no lócus de controle externo sorte azar, mostraram por meio dos dados obtidos que freqüentemente apresentam taquicardia.

A análise da associação entre o lócus de controle externo pessoas poderosas e a freqüência dos sintomas de estresse revelou correlação significativa com dois itens: "Tenho cansaço" ( $p=$ 0,050 - Ginástica Artística, Handebol e Voleibol); "Sinto os olhos lacrimejantes e visão embaçada" ( $p=0,028$ - Ginástica Artística, Handebol), cujos tipos de correlações são evidenciados pelas FIGURAS 47 e 48. 


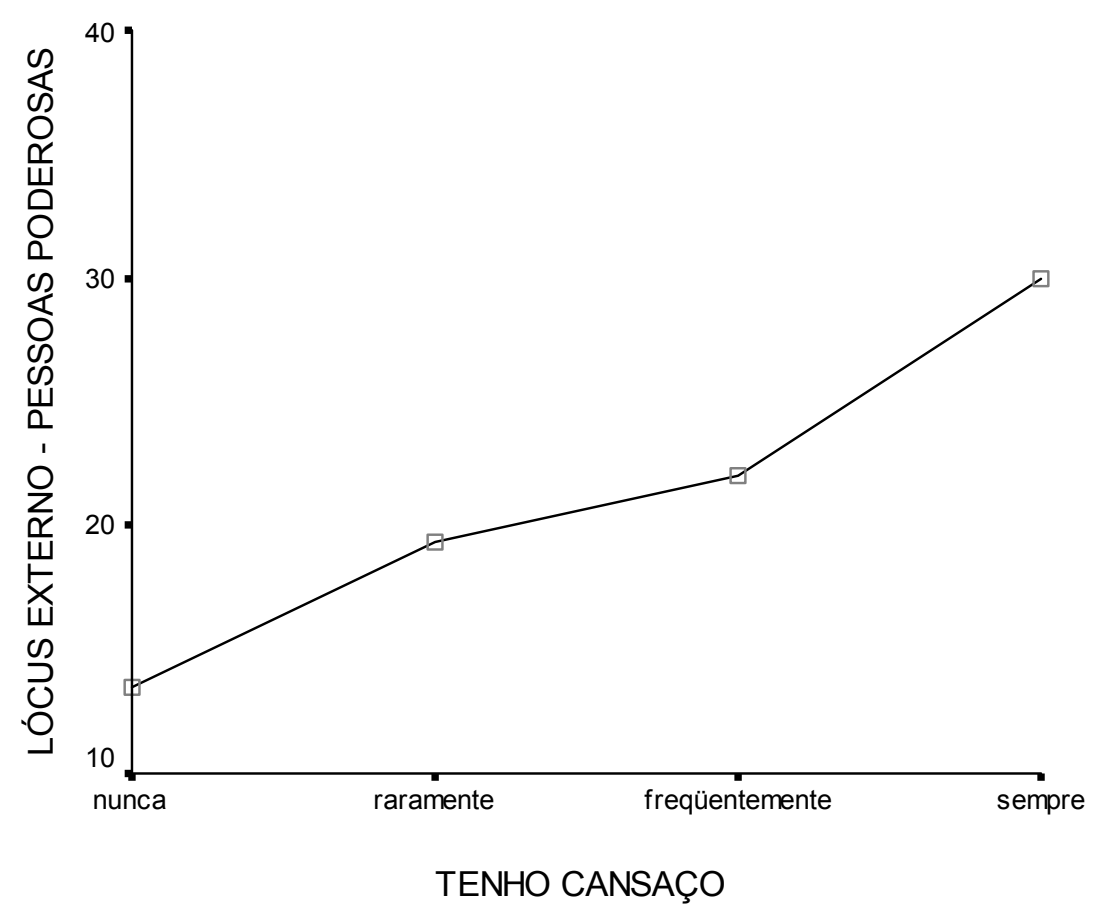

FIGURA 47 - Associação do Lócus de controle externo pessoas poderosas e o cansaço dos atletas da Ginástica Artística, Handebol e Voleibol

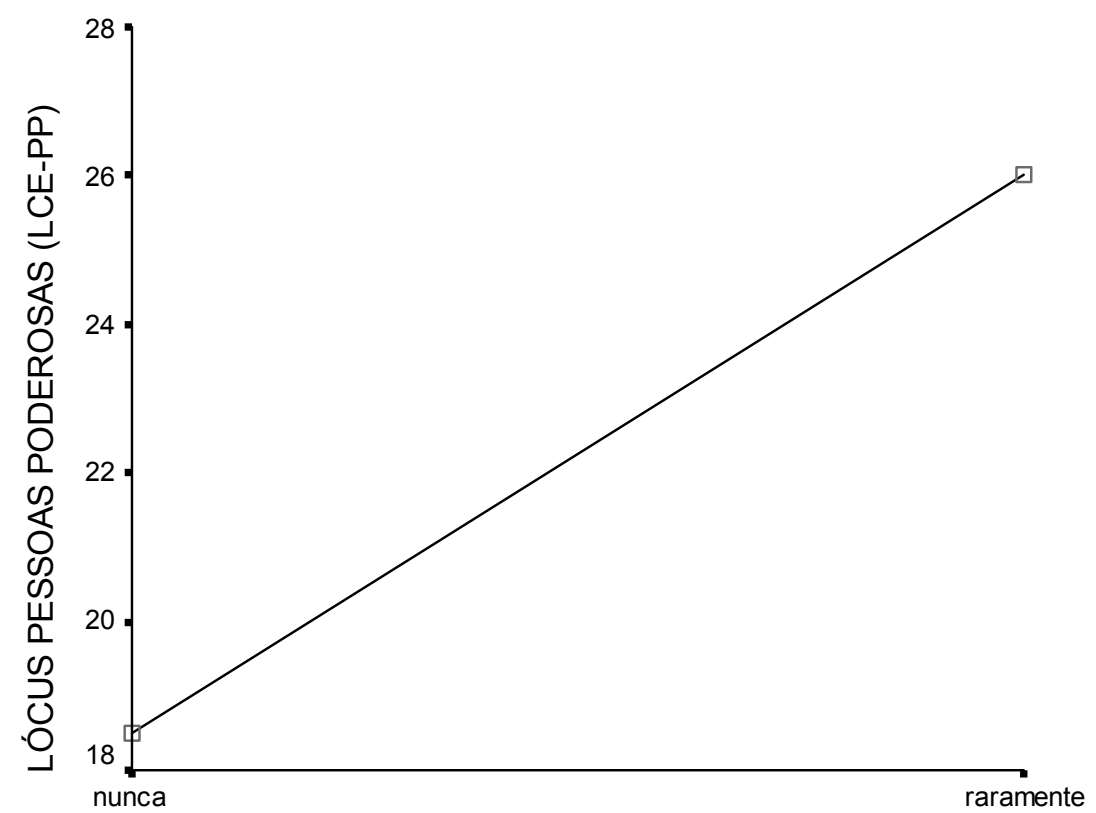

Sinto os olhos lacrimejantes e visão embaçada

FIGURA 48 - $\quad$ Associação do lócus pessoas poderosas, visão embaçada e olhos lacrimejantes dos atletas da Ginástica Artística e Handebol 
Pela FIGURA 47, os atletas do Handebol, Voleibol e Ginástica Artística, que mostraram maior externalidade ao lócus de controle por pessoas poderosas, assinalaram que sentiam maior fadiga. Na FIGURA 48, os atletas que formaram o grupo experiente no esporte no esporte de alto rendimento (Handebol e Ginástica Artística), com menores escores de lócus de controle por pessoas poderosas, mostraram que nunca sentem a visão embaçada e o choro sem convicção (olhos lacrimejantes).

O exame das relações entre lócus de controle e intensidade de sintomas de estresse traz os dados dos atletas da Ginástica Artística e Handebol. A análise pelo coeficiente de correlação de Spearman mostrou quatro associações com o lócus interno (LCI) e o itens: "tenho a sensação que vou desmaiar" ( $p=0,000)$; "fico afônico" ( $p=0,029)$; "ouço zumbidos nos ouvidos" ( $p=0,010)$; e "sinto sobrecarga de trabalho" ( $p=0,036)$; cuja oscilação dos dados é evidenciada pela FIGURA 49.

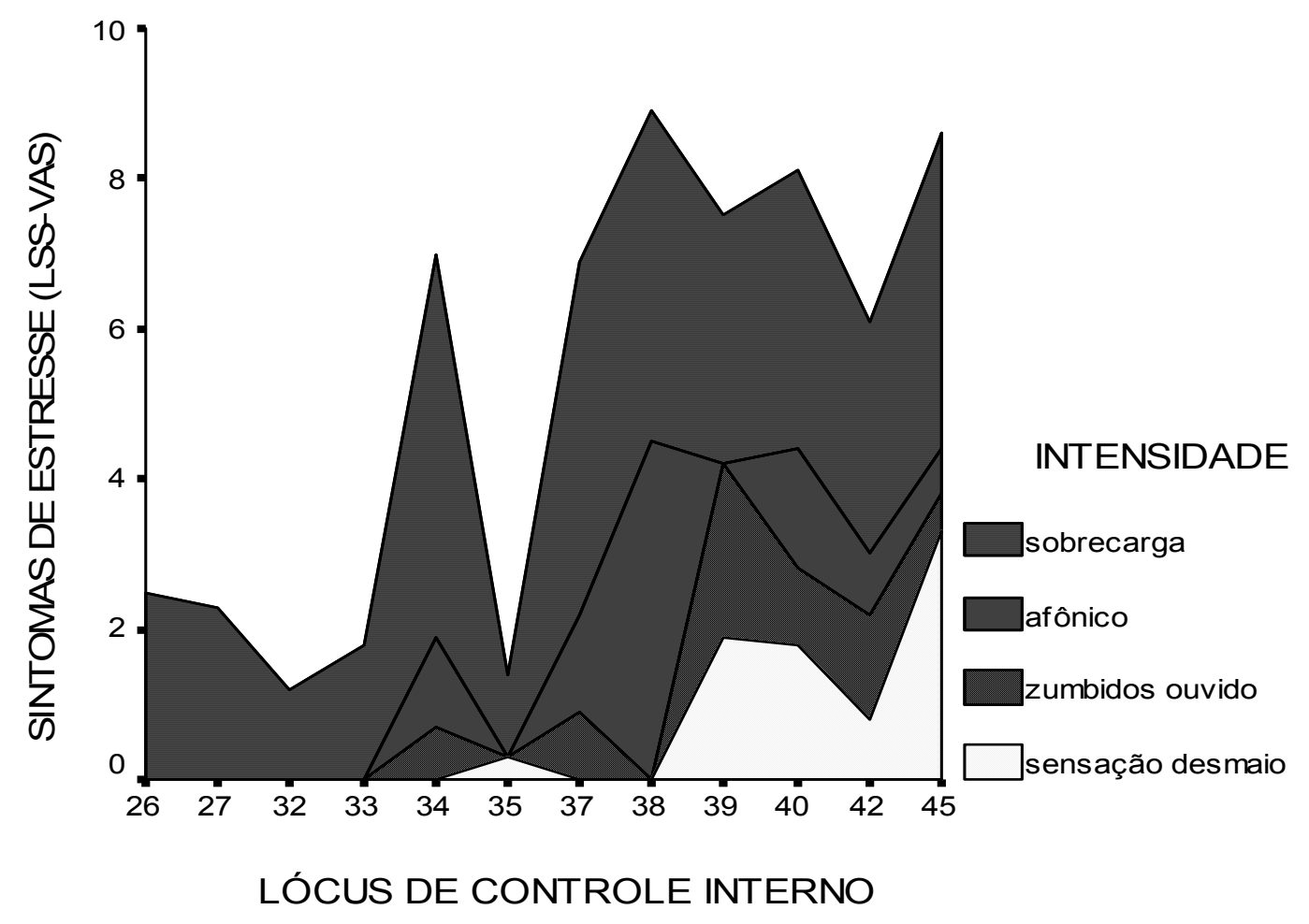

FIGURA 49 - Associação do lócus de controle interno e intensidade de sintomas do estresse dos atletas da Ginástica Artística e do Handebol 
Os dados da FIGURA 49 mostram que os atletas da Ginástica Artística e do Handebol com os maiores índices de lócus interno revelaram maior intensidade de sintomas de estresse: sentem excesso de carga de trabalho; perdem a voz em virtude de lesões no órgão de fonação ou por problemas emocionais; ouvem ruídos nos ouvidos; e têm a sensação que vão desmaiar o "amarelão".

Neste contexto, chama atenção a acentuada correlação $(p=0,000)$ pela associação do lócus de controle interno com o "amarelão" percebido como sensação de desmaiar dos atletas que formaram o grupo com maior experiência no esporte de alto rendimento, a denominada fase de resistência ao estresse na compreensão de NITSCH, ALLMER, HACKFORT, LAZARUS, MCGRATH, SELYE e UDRIS (1981).

BECKER (2007) chama atenção para o caso dos dois desmaios de Freud relatados por Jung na Alemanha. Relaciona os episódios com aspectos que se aproximam da problemática do arquétipo do herói no presente estudo. O senso de heroísmo de Freud, ao criar a psicanálise como método terapêutico revelador e redentor das mazelas da alma humana.

Em 1909, Freud e Jung em viagem de navio aos Estados Unidos da América para realizarem conferências. $\mathrm{Na}$ passagem pela Alemanha, Freud irritado e enervado por causa da insistência de Jung em conhecer os "cadáveres" das turfas dos pântanos de Bremen, desmaiou durante o jantar. Em Munique, 1912, em uma reunião estratégica, alguém desviou a conversa para Amenófis IV (Aknaton - o faraó que mudou de nome e instituiu o monoteísmo no Egito). Mas, Jung irritou-se com a interpretação de Freud: complexo de pai, como uma atitude negativa de Aknaton para com o genitor. Argumentava que Amenófis tinha sido uma pessoa criativa e profundamente religiosa, cujos atos não poderiam ser explicados por resistências pessoais ao pai. Durante essa discussão, Freud desmaiou novamente.

O gênio impelido pelo senso heróico repete a presunção narcisista da criança. O desmaio é visto como a mais maciça negação, a recusa ou incapacidade de continuar consciente. $\mathrm{O}$ ceder representa o abandono do projeto, a mais profunda $\mathrm{e}$ completa admissão que não há força dentro do indivíduo para enfrentar a superfluidade da experiência, BECKER (2007). 
O ceder possui essa mesma conotação no esporte. Ernest Becker, cita Willian James, que refere que o senso heróico, sempre esteve presente no conhecimento popular, mas em épocas "eruditas" não é pensado. Por isso, o mundo apresentar-se essencialmente como um palco para o heroísmo.

A análise entre o lócus de controle externo pessoas poderosas e a intensidade de sintomas de estresse, mostrou no grupo formado pelos atletas com maior experiência no esporte de alto rendimento: Handebol e Ginástica Artística, associação com os itens: "tenho dúvidas sobre mim mesmo (a)" (p=0,046); e "minha pressão se altera" ( $p=\mathbf{0 , 0 4 7}$ ), conforme os resultados destacados pelo FIGURA 50.

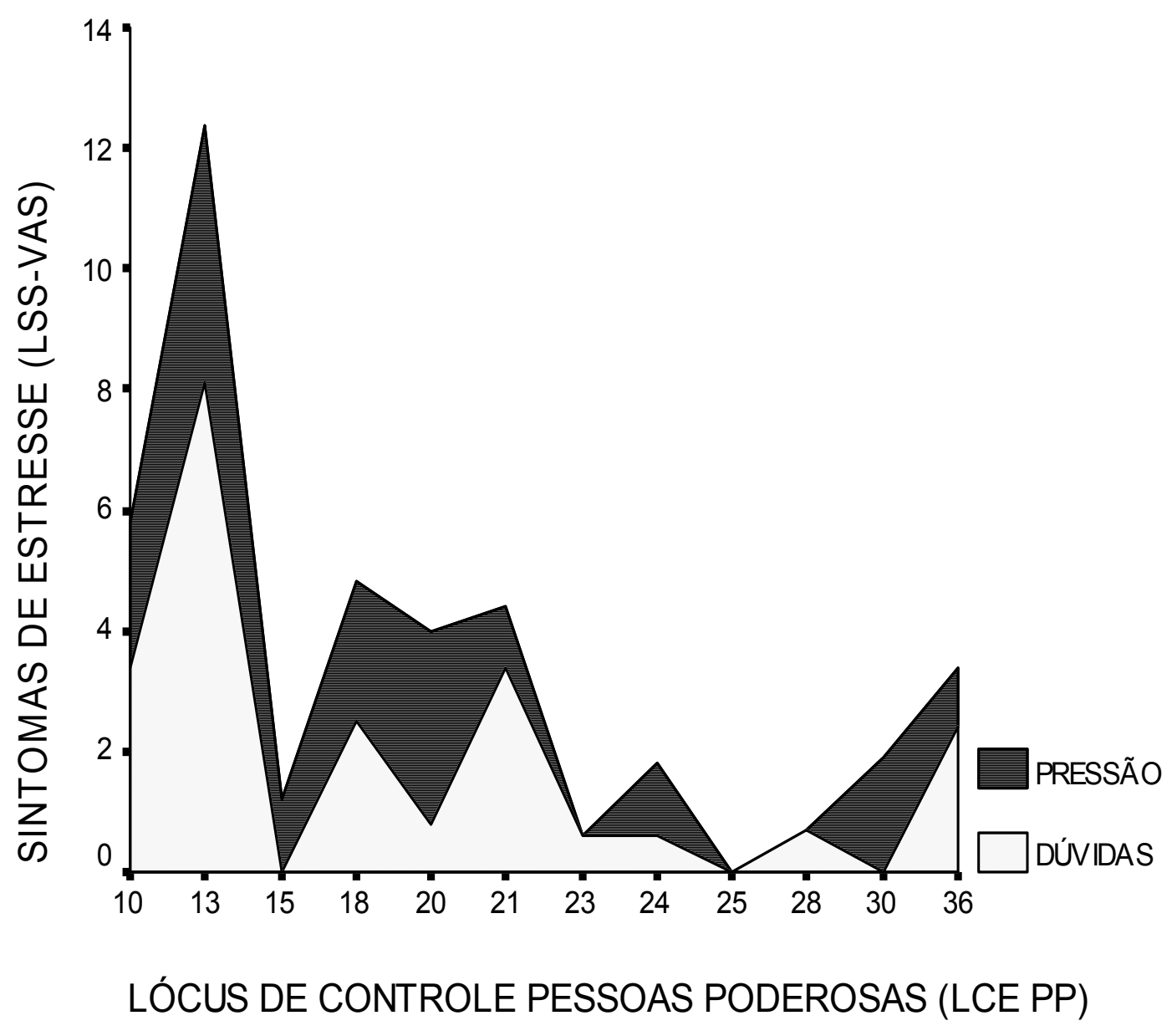

FIGURA 50 - Associação entre Lócus de controle pessoas poderosas e intensidade de sintomas de estresse no Handebol e Ginástica Artística 
Os dados da FIGURA 50 mostram que, no grupo com maior experiência no esporte de alto rendimento (Handebol e Ginástica Artística), a maior externalidade ao lócus de controle por pessoas poderosas associou-se com a menor intensidade de estresse. Os atletas com maiores índices associaram-se com a menor intensidade de estresse: não questionavam a si próprio e sentir com menor intensidade alterações da pressão arterial. Dados que caracterizam indícios das implicações do lócus de controle no coping ao estresse na fase de resistência, definida por NITSCH, ALLMER, HACKFORT, LAZARUS, MCGRATH, SELYE e UDRIS (1981).

O resultado da análise da associação entre intensidade de sintomas de estresse e o lócus de controle dos atletas do grupo com maior experiência no esporte de alto rendimento (Handebol e Ginástica Artística), mostrou associação significativa entre o lócus interno e maior intensidade de sintomas de estresse, pois os atletas desse grupo revelaram que: sentem excesso de carga de trabalho; perdem a voz (lesões no órgão da fonação ou problemas emocionais?); ouvem ruídos (zumbidos) nos ouvidos; e tem a sensação que vão desmaiar, cujo aspecto da pessoa nessa situação, o "amarelão". Entretanto, esses atletas mostraram maior satisfação com o esporte.

Visto que, a análise da associação entre satisfação com o desempenho e expectativas de lócus de controle, mostrou alta correlação $(p=0,001)$, obtida entre lócus de controle interno e a questão formulada por COELHO (2002) sobre satisfação com a performance, inserida nas informações dos dados gerais das características sociotécnicas dos atletas.

Os atletas que atribuíram pouca satisfação ao desempenho (performance), obtiveram menores escores médios de lócus de controle interno. Já os atletas que atribuíram: razoável satisfação e muita satisfação com seus desempenhos obtiveram os índices mais elevados de lócus de controle interno.

Os itens de freqüência e intensidade de sintomas de estresse, que apresentou correlações com o lócus de controle interno e o lócus de controle pessoas poderosas, implicam os aspectos psicológicos envolvidos pelo senso de heroísmo e o estresse no esporte de alto desempenho. Assim, na totalidade, os atletas da Ginástica Artística, Handebol e Voleibol com maiores escores de lócus de 
controle interno, assinalaram que com maior freqüência denotam sentir ansiedade, roem as unhas, ouvem ruídos (zumbidos nos ouvidos) e têm a sensação que vão desmaiar, também, mostraram maior desconfiança em relação a si próprios, ao assinalarem que com maior freqüência sentem-se inseguros.

Dados que chamam atenção sobre a saúde física e psicológica dos atletas, inferência reforçada pela acentuada correlação $(p=0,017)$ entre o lócus de controle interno e o uso de medicamentos pelos atletas que apresentaram maior internalidade, conforme a FIGURA 51.

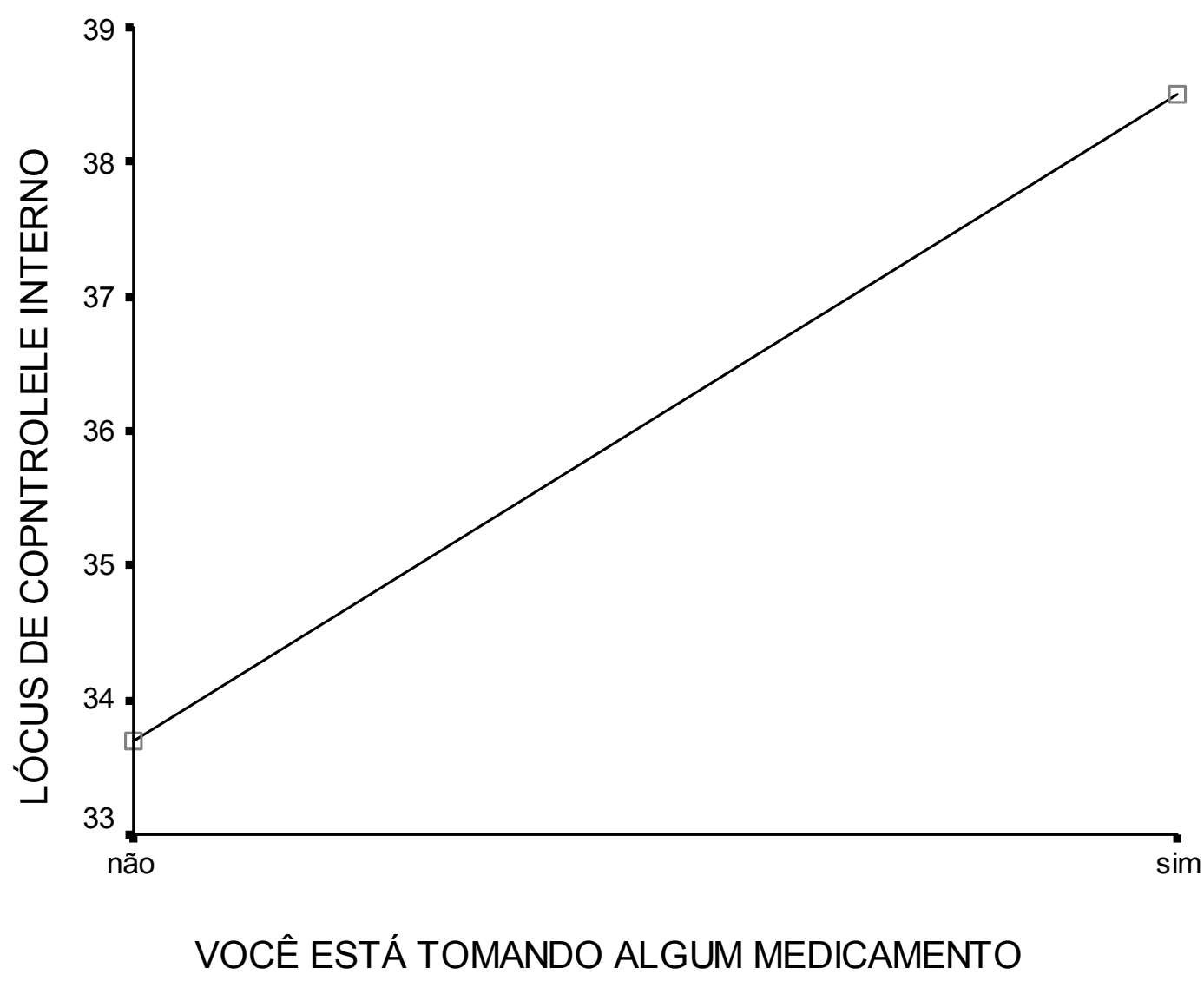

FIGURA 51 - $\quad$ Associação do lócus de controle interno e uso de medicamentos pelos atletas da Ginástica Artística, Handebol e Voleibol 
A FIGURA 51 mostra o tipo de associação entre o lócus de controle interno e o uso de medicamentos. Os atletas com maiores escores de lócus de controle interno mostraram fazer uso dos seguintes medicamentos: Sulfato de condroitina para reconstituição da cartilagem do joelho; analgésicos a base de paracetamol, relaxantes musculares, remédios para pressão e antiinflamatórios (Handebol). Relaxantes musculares e antiinflamatórios para torção (vôlei). Os atletas da Ginástica Artística não mostraram o uso de medicamentos.

No contexto do esporte de alto rendimento, a associação entre maiores índices de lócus de controle interno e o uso de medicamentos, fornecem indícios que confirmam os resultados obtidos em pesquisas sobre modificação de comportamentos de saúde. Pois: não fumantes e ex-fumantes são mais internos que os fumantes; estudantes mais internos têm maior probabilidade de se vacinarem contra gripe; estudantes mais internos mostram atitude mais positivas com relação aos exercícios físicos e à saúde cardiovascular; sujeitos obesos são mais externos, mulheres mais internas têm maior probabilidade de concluir com sucesso programas de controle da obesidade. Estudantes mais internos que recebiam choques elétricos caso errassem um teste de inteligência, mostraram maior aumento da freqüência dos batimentos cardíacos; homens e mulheres negros mais externos e descontentes com suas vidas mostraram taxas significativamente maiores de hipertensão que os internos e contentes, entre outras pesquisas científicas que apoiaram a construção da Escala de lócus de controle da saúde DELA COLETA (2004).

O estudo não revelou associação entre expectativas do lócus de controle e as crenças religiosas: primitiva, intelectual, emocional e ético-moral. Mas, mostrou correlação significativa no grupo experiente no esporte de alto rendimento: Handebol e Ginástica artística. Conforme NITSCH, ALLMER, HACKFORT, LAZARUS, MCGRATH, SELYE e UDRIS (1981), os atletas que na fase de resistência ao estresse que revelaram pelo IPCRE: acreditar que Deus possa ajudar a vencer obstáculos no esporte, apresentaram correlação $(p=0,024)$ com a totalidade da freqüência dos 59 itens de estresse da LSS-VAS. Os itens que mostraram as correlações mais acentuadas $(p<0,02)$ foram: "Fico esgotado emocionalmente" - os atletas que acreditam que Deus possa ajudar a vencer obstáculos no esporte 
associaram-se aos que, com freqüência, se sentem emocionalmente exauridos ( $p=$ 0,009); e "Tenho cansaço" - os atletas que acreditam que Deus possa ajudar a vencer obstáculos no esporte, associaram-se aos que freqüentemente se sentem cansados $(p=0,004)$.

Os resultados deste estudo sobre a associação da crença em Deus como ajuda para superar obstáculos no esporte revelaram com maior freqüência e intensidade de sintomas de estresse. E, os resultados sobre a maior internalidade do lócus de controle na totalidade dos atletas pesquisados que se associaram ao sentimento de estresse mostraram a sensação de sobrecarga de trabalho e a iminência de desmaiar: o "amarelão" reporta novamente a idéia de domínio do arquétipo do herói DURAND (1998), CONCEIÇÃO (2004), CAMPBELL (2007), BECKER (2007), JUNG (2008).

O caso mostrado na revisão de literatura deste estudo, a tragédia protagonizada pela nadadora Renata Câmara Agondi e sua técnica Judith Russo. O suposto pacto "secreto" firmado entre técnicos e atletas em provas de maratonas aquáticas: retirar o atleta da água o atleta, somente no caso de desmaio, HARRISS (2003), BURSON-MARSTELLER (2008), DE CASTELLA (2008).

BECKER (2007) chama atenção para aquilo que denomina principal problema analítico de nossa vida, tornar-se consciente daquilo que se está fazendo para alcançar o heroísmo. Assevera que se tivéssemos a coragem de admiti-lo e retirar o disfarce maciço e os blocos de repressão que pesam sobre nossas técnicas para obter glória, chegaríamos ao problema principal do ser humano: o narcisismo.

Neste contexto, lança um desafio à psicologia científica, mostrar por meio de métodos empíricos válidos, os aspectos psicológicos envolvidos pelo sistema cultural envolvido pelo heroísmo que sustenta e estimula o homem e a sociedade moderna.

PRAT (1923) que teve Willian James entre os sujeitos de sua pesquisa na aplicação do Inventário Pratt de crenças religiosas, cita a obra de RIBOT $^{35}$ "Psicologia dos sentimentos"; as obras de LEUBA ${ }^{36}$ "O medo, o pavor e o sublime na

\footnotetext{
${ }^{35}$ RIBOT, Th. La psychologie des sentiments. Paris : Alcan, 1897.

${ }^{36}$ LEUBA, J. H. Fear awe and the sublime in the religion. American Journal of Religion Psycholopgy, 2, p 1-13, 1906.
} 
religião"; "O estudo psicológico da religião, sua origem, função e futuro". E a obra "Introdução a psicologia social" de Mc DOUGAL ${ }^{37}$. Assevera que o medo impele a formação do grupo, no qual obstáculos que antes pareciam intransponíveis, aparentam tornar-se menores. Mas, adverte que o grupo exige a limitação dos movimentos e da liberdade de ação, que os indivíduos abrem mão voluntariamente por causa da diminuição do senso de responsabilidade pelas falhas e do senso de poder que adquirem. A conclusão de que o medo no esporte de alto rendimento, impactado pelo lócus de controle dos atletas, associado com as reações fisiológicas, designadas por Willian James de impulsos orgânicos, desde tempos imemoráveis, é o sentimento determinante da atitude religiosa e constituintes básicos das crenças e da formação dos grupos.

Neste processo, o "amarelão" impacta com o arquétipo do herói no esporte, em continuidade a seu imaginário envolvido pelas crenças religiosas, desde a origem mítica GOLDEM (1998), BRANDÃO (1998), CONCEIÇÃO (2004). A crença na possibilidade da intervenção divina nas dificuldades e situações críticas, como mecanismo de enfrentamento ao estresse decorrente das pressões internas e/ou externas. Neste estudo, revelou-se uma estratégia de coping pouco eficiente

A revisão de literatura procurou abranger toda a complexidade desse fenômeno pela compreensão da cor no que concerne à luz como objeto estratégico de interesse cientifico. Esta possui natureza quântica e propriedades mecânicas, que constituem estímulos orgânicos de natureza bioelétrica na transmissão de sinais bioquímicos, envolvidos pelas redes neurais associadas com determinantes de natureza genética, com a experiência no percurso ontogenético e a subjetividade na percepção dos estímulos estressores. Assim, os músculos são acionados pelo sistema nervoso simpático e o fluxo sangüíneo oscila. Portanto, em face dos objetivos, dos dados qualitativos e dos resultados empíricos obtidos pela mensuração das oscilações da cor da pele dos atletas do Handebol, da Ginástica Artística e Voleibol, neste estudo, pode-se concluir que:

LEUBA, J. H. The Psychological study of religion: its origin, function and future. New York: Mc Millan, 1912.

${ }^{37}$ Mc Dougal, W. An introduction to the social psychology. London: Methuen \& Co, 1908. 


\section{CONCLUSÕES}

1- Em relação à hipótese central delineada como defesa de tese de doutoramento pode-se afirmar que se comprovaram as proposições do estudo na medida em que se demonstrou que de fato existe o "amarelão" no esporte em decorrência das oscilações cromáticas do tecido epitelial (pré e pós-treinos), mensuradas pelo método espectrofotométrico e caracterizado pela cor da pele significativamente menos amarela e menos clara na parte medial interna do braço e rosto.

2- Comprovou-se que os sintomas de estresse alinham-se com o "amarelão" em decorrência das oscilações cromáticas da cor da pele, como um sinalizador de respostas do organismo humano e comportamento do atleta no ambiente do esporte, como um modelo de manifestações neuropsicológicas, bioinstintivas, psicofisiológicas, psicossociais e intrapessoais.

3- Verificou-se associação estatística significativa da oscilação espectral da cor da pele $\mathrm{Db}^{*}$ (azul-amarelo) das medições de cor no braço dos atletas do Handebol com o somatório total da freqüência $(\boldsymbol{p}=\mathbf{0 , 0 1 7})$ e intensidade ( $\mathbf{p}=$ 0,000) dos 59 itens da Lista de Lista de Sintomas de Stress LSS-VAS.

4- Verificou-se associação estatística significativa da oscilação espectral da cor da pele $\mathrm{Db}^{*}$ (azul-amarelo) das medições da cor no braço dos atletas do Handebol e da Ginástica Artística (grupo com vasta experiência no esporte de alto rendimento), com a intensidade total dos itens da Lista de Lista de Sintomas de Stress (LSS-VAS).

5- Verificou-se associação estatística significativa da oscilação espectral da cor da pele $\mathrm{DL}^{*}$ (claro/escuro) das medidas do rosto dos atletas do grupo experiente no esporte de alto rendimento, com a freqüência $(\mathbf{p}=\mathbf{0 , 0 0 0})$ dos 59 itens da Lista de Lista de Sintomas de Stress (LSS-VAS).

6- $\quad$ No Voleibol (grupo de atletas iniciantes no esporte de alto rendimento), verificou-se apenas uma associação estatística significativa da oscilação da pele $\mathrm{DL}^{*}$ (claro-escuro) das medições do braço e a freqüência do item de 
sintoma de estresse "sinto angústia". Neste grupo, também, constatou-se associação estatística significativa entre a crença na ajuda de Deus para vencer obstáculos no esporte e a freqüência do sintoma de estresse: "sinto dores nas costas".

7- Verificou-se que há uma associação estatística significativa da oscilação espectral da cor da pele $\mathrm{Db}^{*}$ (azul-amarelo) das medições do braço na totalidade dos atletas pesquisados: Handebol, Voleibol e Ginástica Artística, com a freqüência dos itens de sintoma de estresse "tenho medo" $(p=0,000)$ e "qualquer coisa me apavora" ( $p=0,001)$.

8- Não se verificou associação estatística da oscilação espectral da cor da pele $\mathrm{Da}^{*}$ (vermelho-verde) das medições do braço e do rosto dos atletas do Handebol, Voleibol e Ginástica Artística nas análises: parcial, por grupo e total, com a freqüência e a intensidade dos itens da Lista de Lista de Sintomas de Stress (LSS-VAS); Inventário Pratt de crenças religiosas do esporte (IPCRE); e Escala multidimensional de lócus de controle do esporte (ELCE).

9- Não se verificou associação estatística da oscilação espectral da cor da pele $\mathrm{DL}^{*}$ (claro-escuro), Da* (vermelho-verde) e Db* (azul-amarelo) das medições do braço e do rosto dos atletas do Handebol, Voleibol e Ginástica Artística, nas análises: parcial, por grupo e total, com as crenças religiosas primitiva, intelectual, emocional e ético moral.

10- Há evidências de que o atleta, frente a angústia, o medo, o pavor de acidentes e derrotas recorre ao coping pelas crenças em Deus para superar obstáculos no esporte e ao hábito de rezar para obter vitórias nas competições esportivas. Entretanto, este mecanismo de coping mostrou-se pouco eficaz. Os atletas com maior freqüência de sintomas de estresse associaram-se aos que acreditam que Deus possa ajudar a superar obstáculos no esporte e rezam para obter vitórias.

11- No estudo do grupo com maior experiência no esporte de alto rendimento Handebol e Ginástica Artística, houve associação estatística significativa entre a crença na ajuda de Deus para vencer obstáculos no esporte e a freqüência do somatório total dos 59 itens da LSS-VAS $(\mathbf{p}=\mathbf{0 , 0 2 4})$. Nos itens 
que apresentaram correlação mais acentuada: os atletas que acreditam que Deus possa ajudar vencer obstáculos, associaram-se aos que, com freqüência, sentem-se emocionalmente esgotados $(p=0,009)$ e cansados $(p=0,004)$.

12- Os depoimentos dos atletas que mostraram não acreditar na ajuda de Deus para superar obstáculos no esporte, utilizavam o coping pelo foco no problema, por meio da intensificação dos treinos e maior dedicação ao esporte, dado que coloca em perspectiva o estresse como doença do século, uma vez que o esporte apresenta-se como modelo de aprendizagem social de grande poder de influência.

13- O estudo mostrou que houve repetitibilidade dos escores obtidos pela construção e validação da Escala multidimensional de lócus de controle do esporte (EMLCE) e a tendência de maiores índices de lócus interno no esporte de alto rendimento.

14- Os atletas do grupo com maior experiência no esporte de alto rendimento Handebol e Ginástica Artística que revelaram maiores índices do lócus de controle interno mostraram que sentem maior satisfação com o desempenho (performance). Mas, revelaram, também, que se sentem sobrecarregados com maior intensidade $(p=0,036)$; ficam afônicos $(p=0,029)$; ouvem ruídos (zumbidos) nos ouvidos $(\mathbf{p}=\mathbf{0 , 0 1 0}$ ); e têm a sensação que vão desmaiar, o "amarelão", $\mathbf{p = 0 , 0 0 0 .}$

15- Houve correlação significativa entre o lócus de controle interno e o uso de medicamentos nos atletas do Handebol e Voleibol. Os atletas com maiores índices de internalidade associaram-se aos que faziam uso de analgésicos, antiinflamatórios, relaxantes musculares e remédio para pressão.

16- Não houve associação significativa entre os escores totais de lócus de controle interno, externo sorte-azar, externo pessoas poderosas e a oscilação espectral $\mathrm{Da}^{*}$ (vermelho-verde) e $\mathrm{Db}^{*}$ (azul-amarelo) pré e pós-treinos das medidas do rosto e braço dos atletas em campo. 
17- A crença em Deus como ajuda para superar obstáculos revelou-se como um mecanismo de coping ineficiente e, de certa forma, justifica a desconfiança da ciência com relação às crenças, pois o cientista, como o atleta que mostrou buscar por meio de crenças o utilitarismo não obtém resultados, colocando em perspectiva que as crenças religiosas envolvem um sistema mais amplo que o simples utilitarismo na vida dos indivíduos.

18- O presente estudo é inédito e implica uma maior instrumentalização da psicologia do esporte, campo de estudos teóricos e prática que busca à saúde e o bem-estar psicossocial, visto que o esporte apresenta-se como modelo de aprendizagem social em que os atletas são constantemente confrontados com seus limites: físicos, técnicos, táticos e psicológicos nos treinos e competições.

19- O estudo das oscilações da cor da pele do ser humano, a partir deste estudo, poderá contribuir para diagnosticar o estresse em diferentes áreas: na pediatria, o monitoramento das oscilações da cor da pele de bebês; em gerontologia, o monitoramento das oscilações da cor da pele de idosos; na clínica psicológica, o tratamento do pânico e avaliação da eficiência de estratégias de coping. Além de uma série de outras possibilidades aplicação, o auxílio na preparação (física e psicológica) de atletas no esporte de alto rendimento.

20- Nesta tese de doutorado, a comprovação das hipóteses propostas demonstrou o início de pesquisas sobre mensuração da oscilação da cor da pele como um novo método de diagnóstico do estresse que instaura uma nova linha de pesquisa.

Assim, diante dos resultados obtidos nesse estudo e das perspectivas de continuidade da pesquisa sobre estresse e as oscilações da cor da pele pelo método espectrofotométrico. Algumas sugestões são oferecidas aos pesquisadores e aos profissionais do esporte envolvidos em suas dimensões múltiplas, quais sejam: 


\subsection{Recomendações para estudos futuros}

Que os profissionais / pesquisadores da área do esporte façam uma reflexão detalhada sobre o fenômeno das oscilações espectrofotométricas da cor da pele, que se revelaram como um método consistente para a identificação do estresse associado ao "amarelão", - cujas implicações biopsicossociais afetam o desempenho esportivo.

Quanto às sugestões para estudos futuros, pode-se, a partir dessa tese: "Amarelão" no esporte: das oscilações da cor da pele ao coping do estresse por crenças religiosas e o lócus de controle de atletas de Handebol, Ginástica Artística e Voleibol. Sugerir algumas recomendações como pressupostos básicos ao desenvolvimento de novos trabalhos de pesquisa:

- Que estudos similares sejam realizados, permitindo posteriores comparações sobre estresse e amarelão em equipes femininas, masculinas e equipes profissionais de futebol, basquetebol, entre outras modalidades.

- Que as mensurações das oscilações cor da pele sejam realizadas obedecendo aos procedimentos estabelecidos pelo pesquisador (condicionamento controlado para estabilização das condições psicofisiológicas dos sujeitos, antes das mensurações na situação-teste, cujo tempo adequado é um período de 30 a 40 minutos - por meio de três disparos consecutivos, sem valores discrepantes).

- Que a adoção de estratégias de simulação de situações de estresse em pesquisas laboratoriais seja desenvolvida de acordo com as oscilações da cromaticidade do tecido epitelial, definidas pela cor no espaço CIE L*, $a^{*}, b^{*}$. 
- Recomenda-se que nos estudos futuros sobre estresse e oscilações da cor da pele, o delineamento de uma base line, traçada por meio da mensuração contínua da cor da pele em intervalos regulares, antes e depois, da exposição ao estímulo estressor na situação-teste.

- O delineamento de uma base line por meio da mensuração contínua da cor da pele em intervalos regulares, também, poderá permitir o aprofundamento do estudo sobre o ciclo circadiano da melanina.

- Que nos estudos futuros sobre crenças, superstições e expectativas dos acontecimentos no esporte. A Escala multidimensional de lócus de controle do esporte e o Inventário Pratt de Crenças Religiosas no Esporte - não sejam aplicados de modo reducionista. 


\section{REFERÊNCIAS}

AMUCHÁSTEGUI, R. H. Las superficies del poder: consideraciones sobre la cesía como tecnología pedagógico-política. In: CAIVANO, J. L.; AMUCHÁSTEGUI, R. H. (Ed.) Actas del quinto congreso argentino del color. Buenos Aires: La Colmena, 2002.

BARLEIN, R. Newton to Einstein. The trail of the light. United Kingdon, Cambridge: University Press, 2002.

BECKER, E. A negação da morte. Uma abordagem psicológica sobre a finitude da vida humana. 3. ed. Rio de Janeiro: Record, 2007.

BIRREN, F. Color \& human response. New York: Nostrand Reinhold, 1978.

BURSON-MARSTELLER. Solidariedade humana. Catálogo Brasileiro de Profissionais de Relações Públicas. São Paulo, v. 10, p. 19, dez. 1988, editado pelo CONRERP $2^{a}$ Região. Disponível em <http://www.portal-rp.com.br> acesso em: 7 fev. 2008.

CAIVANO, J. L.; MENGH, I; LADISERNIA, N. Un atlas de cesia com muestras pintadas. In: CAIVANO, J. L.; LÓPES M. A. (Org.) Actas del séptimo congreso argentino del color. Buenos Aires: Universidade de Buenos Aires, Grupo Argentino Del Color, 2006.

CAIVANO, J. L. O homem necessita da cor para viver: palestra, 18 set. 2008. Encontro Brasileiro da cor. 4. São Paulo: Associação Pró-cor do Brasil, 2008. CAMPBELL, J. O poder do mito. 25 ed. São Paulo: Palas Athena, 2007 
CASTELLA, T. Channel number one. Telegraph.co.uk. Disponível em: <http://www.telegraph.co.uk/arts> Acesso em: 28 abr. 2008.

CHANNEL SWIMMING ASSOCIATION. Hall of fame. Site oficial... Traz a lista dos vencedores das provas realizadas na Travessia do Canal da Mancha. <http://www.channelswimmingassociation.com> Acesso em: 24 nov. 2008.

COELHO, M. A. B. C. Sinais psicofisiológico e vocais da ativação por estresse no telejornalismo ao vivo. 2002, 247 p. Tese. (Doutorado em Psicologia). IP USP, São Paulo.

CONCEIÇÃO, P. F. M. Perfil Perséfone: um estudo sobre crenças religiosas e lócus de controle de atletas de handebol. 2004. 183 p. Dissertação (Mestrado em Educação Física). EEFE USP, São Paulo.

CONCEIÇÃO, P. F. M.; SIMÕES, A. C. Persephone's faces: a study of locus control of handball players: In Conference of the International Test Commission, 5., 2006. Contents ... Bruxelas: Universite Catholic de Louvain, 2006.

DAMATTA, R. A. A casa e a rua. Espaço cidadania mulher e morte no Brasil: Rocco, 2003.

DE ROSE JUNIOR, D. Stress pré-competitivo no esporte infanto-juvenil: elaboração e validação de um instrumento. 1996. 110p. Tese (Doutorado em Psicologia). Instituto de Psicologia da Universidade de São Paulo, São Paulo.

DELA COLETA, J. A. A Escala de lócus de controle interno-externo de Rotter: um estudo exploratório. Arquivos brasileiros da psicologia. Rio de Janeiro, v. 31, n.4,1979.

. Locus de controle: uma variável no processo de aprendizagem social de Julian Rotter e um construto na atribuição de causalidade. Atribuição de causalidade: teoria e pesquisa. Rio de Janeiro: Fundação Getulio Vargas, 1982. 
DELA COLETA, M. F. Escala multidimensional de locus de controle de Levenson. Arquivos Brasileiros da Psicologia. Rio de Janeiro, v.32, n. 2, 1987. . Locus de controle da saúde. In: DELA COLETA M. F. (Org.) Modelos para pesquisa e modificação de comportamentos de saúde: teorias estudos instrumentos. Taubaté: Cabral 2004, p. 199-252.

DURAND, G. Campos do imaginário. Lisboa: Instituto Piaget, 1998.

ENCYCLOPAEDIA BRITANNICA. Disponível em: <http://www.britannica.com> Acesso em: 7 dez. 2008. (yellow).

FARINA, M. Psicodinâmica das cores em publicidade. (1920). São Paulo: Editora da Universidade de São Paulo, 1975.

FREITAS, M. H. Crenças religiosas e personalidade em estudantes de psicologia: um estudo por meio do questionário Pratt e do método de Rorschach. 2002. 275f. Tese (Doutorado em Psicologia). Instituto de Psicologia, Universidade de Brasília, Brasília.

FREUD, S. (1927). O futuro de uma ilusão. In Edição standard das Obras psicológicas completas de Sigmund Freud. Rio de Janeiro: Imago, $1972 \mathrm{v}$. XXI, p. $81-171$.

GEGENFURTNER, K. R.; SHARPE, L. T. Color vision from genes to perception. United Kingdom, Cambridge: University Press, 2002.

GIANNETTI, E. Auto-engano. 1. reimp. São Paulo: Companhia das letras, 1998.

GOLDBERGER, L.; BREZNITZ, S. Handbook of stress: theoretical and clinical aspects. 2 ed. New York: The Free Press, 1986.

GRAVLEE, C. C.; DRESSLER, W.W.; BERNARD, H.R. Skin color, social classification, and blood pressure in southeastern Puerto Rico. American Journal of Public Health v.95, n.12, p. 2191-2197, 2005. 
GRAY'S ANATOMY OF THE HUMAN BODY. 20. ed. U.S.A. The distribution of the blood vessels in the skin of the sole of the foot. Vascularização da epiderme por artérias e veias. Litografia, publicação original 1918. Disponível em: <http://en.wikipedia.org/wiki/Skin\#Skin_layers> Acesso em: 23 fev. 2008.

HALL, C. S.; LINDZEY, G.; CAMPBELL, J. B. Teorias da personalidade. Porto Alegre: Artes Médicas, 2000.

HARRISS, J. That chilly sleeve of water between Dover and Calais still exercises a tidal pull on the imaginations of marathon swimmers. Paris-Based: A Sampler of Articles by an American Journalist Abroad. Artigo disponível em <http://www.geocities.com/harriss75007/channel.htm> Acesso em: 16 mar, 2003.

HIGGS, R. J. Sport and religion and religion and Sport: review essay. Journal of the philosophy of sport. Champaign: Human Kinetics, v. 23, p. $104-09,1996$.

HOFFMANN, F. S.; ZOGBI, H.; FLECK, P. e MÜLLER. A integração mente corpo em psicodermatologia. Psicologia teoria e prática. v. 7(1), p. 51 - 60, 2005.

HOUAISS, A. Dicionário Houaiss da Língua Portuguesa. Rio de Janeiro: Objetiva, 2001, (amarelo, amarelado, amarelão, expectativa, lócus).

HUNTERLAB (2001). Insight on color. Hunter L, a, b versus CIE 1976 L* $^{*} a^{*} b^{*}$. Applications Note. Virginia, U.S.A: Technical Services Department Hunter Associates Laboratory, v. 13, p. 1-3, 2008.

JONES, M. Locus of control and superstitious behavior: a visit to the putting green. In: Annual Arkansas symposium for psychology students, 13, july, 2001. Hendrix News Release. Arkansas: Hendrix College, 2001.

JUNG, C. G. O homem e seus símbolos. ed. esp. Rio de Janeiro: Nova Fromteira, 2008.

KORZAN, W. J.; SUMMERS, T. R.; SUMMERS, C. H. Manipulation of visual sympathetic sign stimulus modifies social status and plasma catecholamines. General and Comparative Endocrinology, v.128, n. 2, p. 153-16, 2002. 
LEDOUX, J. O cérebro emocional. Os misteriosos alicerces da vida emocional. 7. ed. Rio de Janeiro: Objetiva, 1998.

LEVENSON, H. Multidimensional locus of control in psychiatric patients. Journal of Consunting and Clinical psychology, v. 41, n. 3, p. 397-404, 1973.

LIMONGI FRANÇA, A. C.; RODRIGUES, A. L. Stress e trabalho: uma abordagem psicossomática. São Paulo: Atlas, 2005.

LIPP, M. E, N. Avanços da pesquisa no controle do stress. In: Conferência do capítulo latino americano da Society for psychotherapy research, 8., 2008. Caderno de resumos ... Campinas: Programa de Pós-graduação em psicologia da Pontifícia da Universidade Católica de Campinas, 2008.

MOLLON, J. D. The origins of modern color science. In: SHEVELL S. K. (Org.) The science of color. 2. ed. UK, Langford Lane: Elsevier, 2003.

MURACAMI COLOR RESEARCH LABORATORY. CMS-35SP. Espectrofotômetro portátil de colorimetria comercializado em Tóquio. Disponível em < http://www.mcrl.co.jp/p_meter/CMS35.html I> Acesso em: 16 out. 2006.

NITSCH, J. R.; ALLMER, H.; HACKFORT, D.; LAZARUS, J.E.; McGRATH, J.E.; SELYE, H.; UDRIS, I. Stress: theorien unteruchugen und massnahmaen. Stuttgart: Verlag Hans Huber, 1981.

PAIVA, G. J. AIDS, psicologia e religião. Psicologia: teoria e pesquisa, Brasília, v. 14, n. 1, p. 027-034, 1998.

PORTNOI, A. G. Dor, stress e coping: grupos operativos em doentes com síndrome de fibromialgia.1999. 256f. Tese (Doutorado em Psicologia) - Instituto de Psicologia, Universidade de São Paulo, São Paulo.

PRATT, J. B. The psychology of religious belief. New York: Macmillan, 1907. The religious consciousness: a psychological study. New York: the Macmillan, 1923.

ROTTER, J. B.; CHANCE, J. E.; PHARES, E. J. Applications of a social 
learning theory of personality. New York: Holt, Rinehart and Winston, 1972.

ROULLOT, E.; AUTEGARDEN, J.E.; DEVRIENDT, P. e LEYNADIER, F. Segmentation of erythema from skin photographs for assisted diagnosis allergology. In: Third International Conference on Advances in Pattern Recognition 2005. Cadernos de leitura. UK, Bath: Heidelberg Springer Berlin, v. 3687, p. 754-763, 2005.

SANT' ANNA; GIOVANETTI; CASTANHO; BAZHUNI e LA SELVA. A expressão de conflitos psíquicos em afecções dermatológicas: um estudo de caso de uma paciente com vitiligo atendida com jogo de areia. Psicologia Teoria e Prática: São Paulo, v. 5(1), p. 81 - 96, 2003.

SEER'S WEB-BASED TRAINING MODULES. Anatomy of the Skin. Programa de treinamento de prevenção ao câncer: U.S. National Cancer Institute's Surveillance. Epidemiology End Results (SEER) Program. Emory University. Disponível em : <http://training.seer.cancer.gov/ss_module14_melanoma/ unit02_sec01_anatomy.html> Acesso em 20 fev. 2008.

SERUP, J.; GREGOR, B. E. J.; GARY, L. G. Hand book of non-invasive methods and the skin. 2 ed. New York: Taylor, 2006.

SIMÕES, A. C. Ideologia de liderança no esporte: uma visão do "ideal próprio" dos técnicos e "real equipe" dos Atletas, 1996. 162f. Tese (Livre Docência em Educação Física). Escola de Educação Física e Esporte, USP, São Paulo.

- Psicossociologia aplicada ao esporte: contribuição para sua compreensão. Revista Paulista de Educação Física, v. 13, p. 88 - 97, 1999.

. Esporte de Performance. In; KISS, M. A. P. DM (Org.). Esporte e exercício: avaliação e prescrição. São Paulo: Roca, 2003, p. 249-288.

SINGER, R. N.; ORBACH, I. Persistence, excellence and fulfillment. LIDOR, R.; BAR-ELI, M. (Ed.) Sport psychology: Linking theory and practice. Morgantow: Fitness information Technology, 1999.

STAMATAS, G.N.; KOLLIAS, N. Blood stasis contributions to the perception of 
skin pigmentation. Journal of Biomedical Optics, v. 9 n.2, p. 315-322, 2004.

TAMAYO, A. Validade Fatorial da escala Levenson de Lócus de Controle. Psicologia: teoria e pesquisa, Brasília, v. 5, n. 1, p. 111-122, 1989.

THE COLUMBIA ELETRONIC ENCYCLOPEDIA. Vision in Humans. New York: Columbia University Press. Disponível em: >http://encyclopedia2. thefreedictionary.com/chromatic+vision<. Acesso em: 16 mar. 2008.

UCHIDA, A. A New Instrument for Measuring the Human Skin Color: A noncontact-type spectrocolorimeter with a globe for light integration. Departamento de cirurgia plástica do instituto de medicina clinica da Universidade de Tsukuba - Japão. Disponível em: <http://biocolor.umin.ac.jp/book200102/din01022802.pdf> acesso em: 16 out. 2006.

UNITED STATES GOVERNMENT. Skin Layers. Esquema de representação das estruturas da pele desenvolvida para o Governo federal dos EUA. Domínio Público. em: <http://upload.wikimedia.org/wikipedia/commons/3/34/Skin.jpg> Acesso em: 20 fev. 2008.

VALBERG, A. Light, vision, color. England, Chichester: Jonh Wiley, 2005.

VAN DER SALM, A. L.; NOLAN, D.T.; SE WENDELAAR BONGA S. A. In vitro evidence that cortisol directly modulates stress-related responses in the skin epidermis of the rainbow trout (Oncorhynchus mykiss Walbaum). Fish Physiol. Biochem, v.27, n. 1-2, p.9-18, 2002.

VAN DER SALM, A.L.; SPANINGS, F.A.T.; GRESNIGT, R.; WENDELAAR BONGA, S.E.; FLIK, G. Background adaptation and water acidification affect pigmentation and stress physiology of tilapia, Oreochromis mossambicus. Gen. Comp. Endocrinol. v.144, p.51-59, 2005.

VASCONCELLOS, E. G. Stress, coping und soziale kompetenz bei kardiovaskularen erkrankunger. 1985. 337f. Tese (Doutorado em Psicologia). 
Institut for psychiatrie, Universitatin Munchen, Munchen.

VASCONCELLOS, E. G.; DE ROSE, Junior D. Perfis de estresse e atribuição causal em jogadoras da seleção brasileira de basquetebol: In Congresso interno do Instituto de Psicologia, 1., 1991, São Paulo. Anais Eletrônicos ... São Paulo: IPUSP, 1991. Disponível em: >http://www.usp.br/eef/esporte/comp.htm15<. Acesso em: 16 mar. 2003.

VYGOTSKY, L. S.; LURIA, A. R. Estudos sobre a história do comportamento. Símios, homem primitivo e criança. Porto Alegre: Artes Médicas, 1996.

WEITEN, W; LLOYD, M. A.; DUNN, S. A.; HAMMER, E. Y. Psychology applied to modern life: adjustment in the 21st century. 9 ed. California: Wadsworth Pub Co, 2008. 


\section{ANEXO I - Parecer do Comitê de Ética}

Of.CEP/412007/EEFE/05.05.2007

Senhor(a) Pesquisador(a)

O Comitê de Ética em Pesquisa (CEP) da Escola de Educação Física e Esporte da Universidade de São Paulo, em reunião ordinária realizada em 27 de abril de 2007, aprovou o Protocolo de Pesquisa n. 2006/49 - "Complexo ícaro: um estudo sobre lócus de controle, crenças religiosas e a cor da pele de atletas de alto nivel", sob sua responsabilidade.

Solicitamos a observância da apresentação de relatório ao término do desenvolvimento da pesquisa, em fevereiro de 2008.

Atenciosamente,

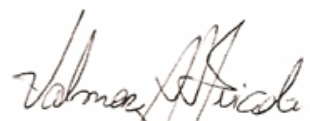

Prof. Dr. Valmor Axberto Augusto Tricoli Presidente do Comitê de Ética em Pesquisa

IImo(a). Sr(a)

Prof(a). Dr(a). Antonio Carlos Simões 